\title{
RESPOSTA DINÂMICA DE REATOR UASB EM ESCALA PILOTO SUBMETIDO A CARGAS ORGÂNICAS E HIDRÁULICAS CÍCLICAS: MODELOS MATEMÁTICOS E RESULTADOS EXPERIMENTAIS
}

KARINA QUERNE DE CARVALHO

Tese apresentada à Escola de Engenharia de São Carlos da Universidade de São Paulo, como parte dos requisitos para obtenção do título de Doutor em Engenharia Civil área: Hidráulica e Saneamento.

ORIENTADOR: Prof. Titular EDUARDO CLETO PIRES

São Carlos

$-2006-$ 
Ficha catalográfica preparada pela Seção de Tratamento da Informação do Serviço de Biblioteca - EESC/USP

Carvalho, Karina Querne de
Resposta dinâmica de reator UAss em escala piloto
submetido a cargas or gânicas e hidráulicas cíclicas :
modelos matemáticos e resultados experimentais / Karina
Querne de Carvalho. -- são Carlos, 2006.
Tese (Doutorado) -- Escola de Engenharia de são
Carlos-Universidade de são Paulo, 2006.
Área: Hidráulica e Saneamento.
Orientador: Prof. Tit. Eduardo Cleto Pires.
1. Processo anaeróbio. 2. Esgoto sanitário.
3. Variação de vazão. 4. Comportamento dinâmico.
5odelação matemática. I. Título.


FOLHA DE JULGAMENTO

Candidata: Engenheira KARINA QUERNE DE CARVALHO

Tese defendida e julgada em 14-12-2006 perante a Comissão Julgadora:

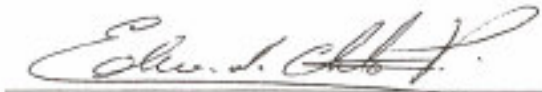

Aprousdo

Prof. Titular EDUARDO CLETO PIRES (Orientador)

(Escola de Engenharia de Såo Carlos/USP)

Silnia C.S. Ponimeli APRONADA

Prof ${ }^{\underline{y}}$. Dt ${ }^{\lambda}$. SILVIA CLAUDIA SEMENSATO POVINELLI

(Escola de Engenharia de São Carlos/USP)

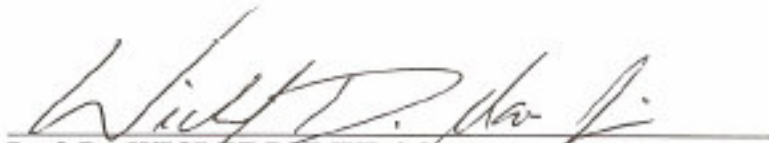

Prof. Dr. WICLEF-DYMURG MARRA JUNIOR

(Escola de Exgenharia de Sá Carlos/USP)

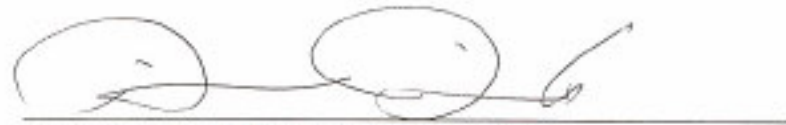

Prof. Dr. REINALDO PISANI JUNIOR

(Universidade de Ribeirao Preto/UNAERP)

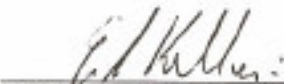

Prof. Dr. ERICH KELLNER

APROUADA

(Centro Universitário de Lins/UNILINS)

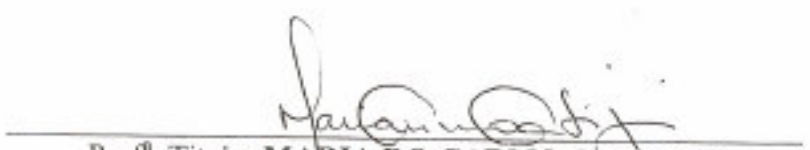

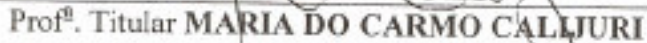

Coordenadora do Programa de Pós-Graduaçạo em

Engenharia (Hidráulica e Saneamento) e

Presidente da Comissâo de Pós-Graduação 
"Nenhum vento será favorável àquele navio que não souber em qual porto atracar".

(anônimo) 
Aos meus pais Olivia e Dacymar... meus grandes exemplos de vida Aos meus irmãos Thales e Caio... meus dois amores 


\section{AGRADECIMENTOS}

A Deus pela vida...

Ao Professor Dr. Eduardo Cleto Pires pela orientação desta tese, confiança, incentivo e amizade, sem os quais esse trabalho não teria sido desenvolvido.

Ao Professor Dr. Marcelo Zaiat pelo exemplo de pesquisador e educador, pela solidariedade e importantes sugestões no desenvolvimento dessa pesquisa.

À amiga Dra. Andréa Paula Buzzini pela amizade, atenção e importantes sugestões no desenvolvimento deste trabalho.

Aos co-orientadores estrangeiros Professores Dr. Jurg Keller e Dr. Zhiguo Yuan pela oportunidade de aprendizado com o grupo do Advanced Wastewater Management Centre da Universidade de Queensland/Brisbane/Austrália.

À Professora Luísa Fernanda Ribeiro Reis pela confiança e pelo espaço cedido no Laboratório de Simulação do Departamento de Hidráulica e Saneamento.

Aos Professores Antonio Carlos Peralta e Roberto Cruz Lessa do Departamento de Engenharia Civil da Universidade Estadual de Maringá por me incentivarem a seguir esse caminho.

À Vó Erna e à Vó Maria (in memorian) pelo amor incondicional e pelos sábios ensinamentos.

A Fernando Hermes Passig pelo companheirismo, ensinamentos, atenção, carinho, amor.

Aos amigos capixabas Monique Toledo Salgado e Sergio Ricardo Toledo Salgado pela amizade e companheirismo compartilhados durante o mestrado e doutorado. 
Às amigas queridas que aqui encontrei: Monique Toledo Salgado, Luciana Silva Peixoto, Andréa Paula Buzzini, Lara Steil; Luana Maria Marelli, Sávia Gavazza dos Santos, Glauce Pereira, Anna Paola Bubel, Cáscia Suassuna, Adelena Maia, Kátia, Cláudia Megda, Cristina Iamamoto, Alessandra e Giselda Bragança Mendes, Larissa Olmo Villela, Liliane Lazzari Albertini, Isabel Sakamoto e Jucélia Cabral Mendonça com quem tive o prazer de compartilhar momentos de alegria, amizade e afeto.

Aos amigos maringaenses Karina e Pedro Donida, Ana Raquel Santos, Adriana Zafanelli Dias dos Reis, Ricardo Gonçalves Dias, Jaqueline Kelly Rabassi, Alexsandra Schwederke e Rosália Honda que mesmo distantes me incentivaram na busca por essa conquista.

Aos amigos Sergio Ricardo Toledo Salgado, Thiago José Momenti, Francisco Gláucio Cavalcanti, Leonardo Barra Santana, Leonardo Vieira Soares, Pedro Ivo dos Santos, João Moreira, André, Alexandre Kepler, Renato Siman, Sergio Siebra Moreira e Fernando Colombo.

Aos amigos australianos Janani Moha, Gülsum Yulmaz, Vel Vadivelu, Monica Barbu, Leah e Dana Foley, Mec, Bernardino Virdis, You Day, Cristal e Melvin, Penina e Roberto, Stéphanie Bohanne, Maithe, Felippo Fiorani e Stefano Freguia.

Aos amigos José Antônio Tosta e Klebber Formiga pelas importantíssimas explicações de programação no Matlab.

Aos amigos Anita, Cássia e Cláudio Antonio Lima, Ana Clara, Samantha e Rogers Ribeiro, Olga e Francisco Vela, Silvana, Gabriel e Marcelo Zaiat.

Aos colegas do grupo de anaeróbios: Professora Dra. Maria Bernardete Varesche, Professora Dra. Elizabeth Moraes, Maria Ângela Talarico Adorno, Dra. Eloísa Pozzi, Marilu Parsekian, Bruna Soares, Leonídia Daniel, Kátia, Iolanda Duarte, Estela Oprime, Eduardo Cattony, José Alberto Leite, Ariovaldo da Silva, Arnaldo Sarti, Julia, Luciana, Gustavo e André Campos, Flávia Talarico Saia, Neyson Mendonça, 
Ana Paula Miqueleto, Daniela , Douglas Silva, Aurélio Picanço, Márcia Damianovic, Maria Magdalena Ferreira Ribas, Alexandre Colzi, Luis Hamilton, Katt e Lucas Garbossa, Gabriel Souto, Gunther e Adriana Brucha, Mércia Domingues, Flávio Bentes Freire, Leonardo Damasceno, Rodrigo Moruzzi, Kelly Rodrigues, pelo apoio e excelente convívio.

Aos funcionários do Departamento de Hidráulica e Saneamento, Sá, Pavi, Rose, Bruno, Flávia, Fernanda, Márcia Campos, André Canale Garcia, Sérgio Doricci, Roberto Bergamo, Valdecir Arruda, Paulo Fragiácomo, Maria Aparecida Peres Viúves, Ana Paula Paim, Teresinha e Wagner Lamon pela gentileza e atendimento, meus sinceros agradecimentos.

Ao Departamento de Hidráulica e Saneamento e a todos os professores por toda a ajuda.

À Fundação de Amparo e Pesquisa do Estado de São Paulo pela bolsa de doutorado que proporcionou a realização deste trabalho.

À Capes pela bolsa de estágio de doutorado na Universidade de Queensland na Austrália.

A todos aqueles que contribuíram, direta ou indiretamente, para a realização deste trabalho. 


\section{SUMÁRIO}

LISTA DE FIGURAS …..........................................................................................................................

LISTA DE TABELAS................................................................................................................. VI

LISTA DE SÍMBOLOS E ABREVIATURAS..............................................................................IX

RESUMO ...................................................................................................................................XVII

ABSTRACT ............................................................................................................................... XVIII

1. INTRODUÇÃ

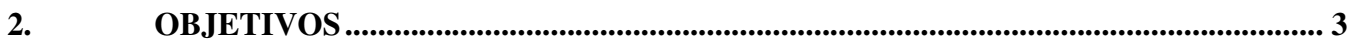

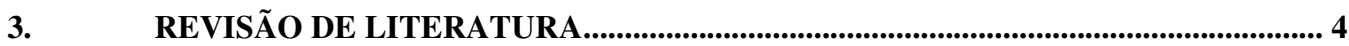

3.1 REATORES UASB (UPFLOW ANAEROBIC SLUDGE BLANKET) …………………............ 4

3.2 COMPORTAMENTO DE REATORES ANAERÓBIOS SUBMETIDOS A CARGAS DE

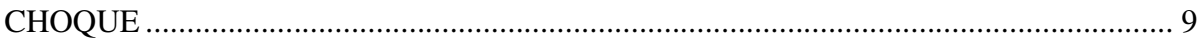

3.2.1 VARIAÇÕES NA VAZÃO E COMPOSIÇÃO DOS ESGOTOS AO LONGO DO DIA...10

3.2.2 EFEITOS DAS VARIAÇÕES DAS CARGAS ORGÂNICAS E HIDRÁULICAS .............11

3.2.3 EFEITO DA DURAÇÃO E FREQÜÊNCIA DOS DISTÚRBIOS …………..................16

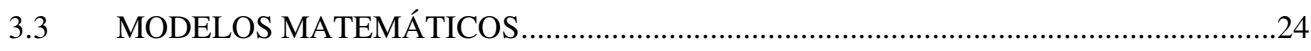

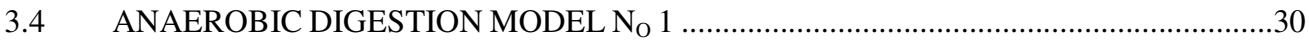

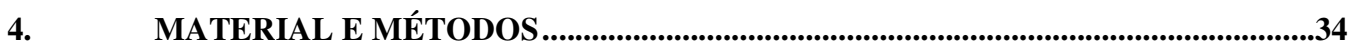

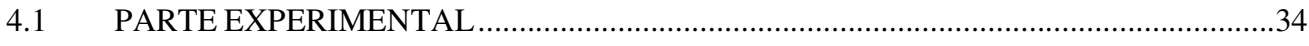

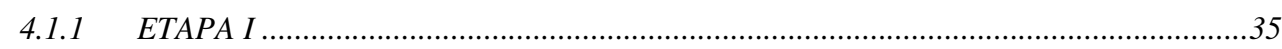

4.1.1.1 REATOR UASB EM ESCALA PILOTO (146 L) ……………………………….... 35

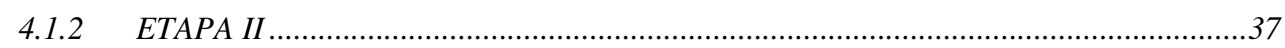

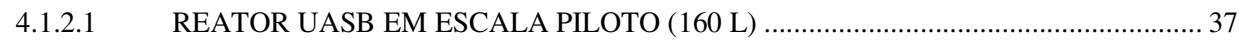

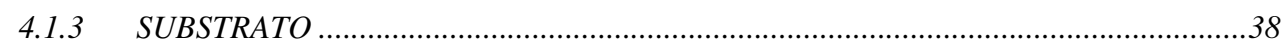

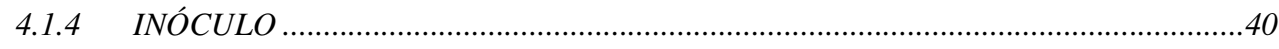

4.1.5 OPERAÇÃO E MONITORAMENTO DO REATOR UASB …………………...............

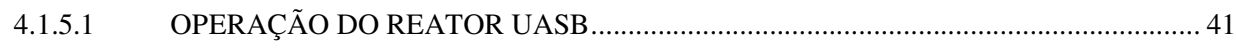

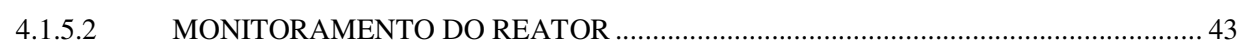

4.1.5.3 EXAMES MICROBIOLÓGICOS ..................................................................... 46

4.1.5.4 ENSAIOS DE ATIVIDADE METANOGÊNICA......................................................... 47

4.1.5.5 ANÁLISE DA COMUNIDADE MICROBIANA ………………………………........ 48

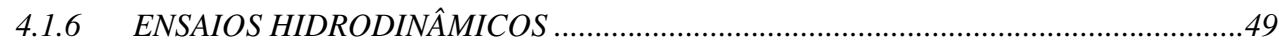

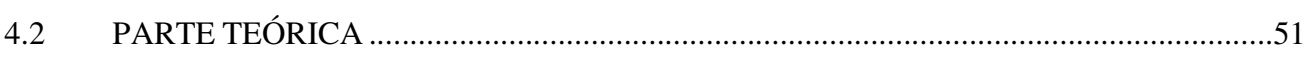

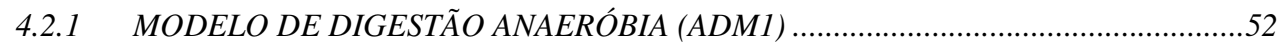

4.2.1.1 PROCESSOS EXCLUÍDOS DO MODELO ADM1 _..................................................... 56 


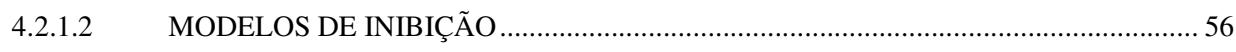

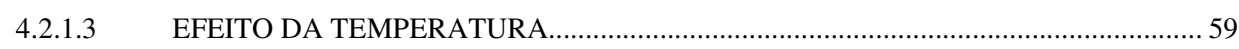

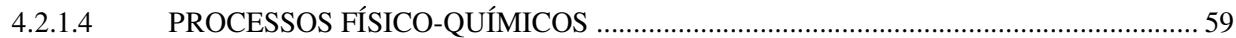

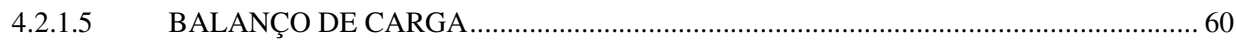

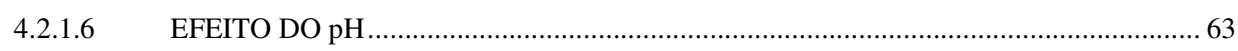

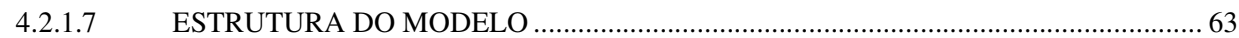

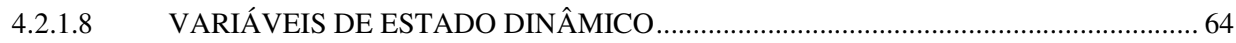

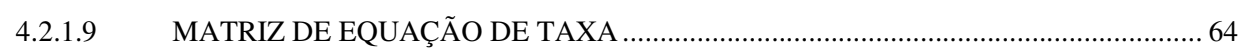

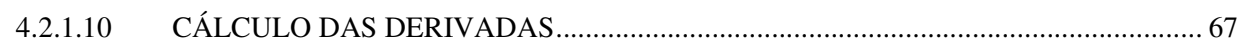

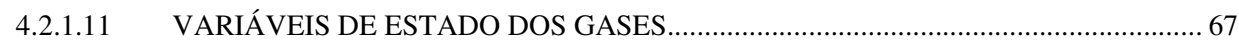

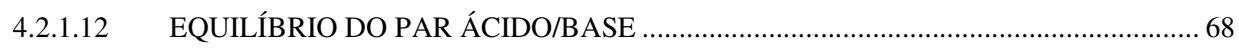

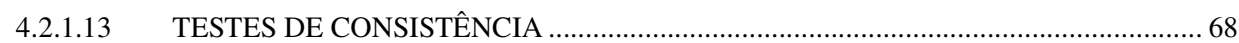

4.2.1.14 BALANÇO DE DEMANDA QUÍMICA DE OXIGÊNIO (DQO) ................................ 69

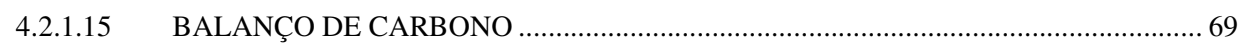

4.2.1.16 BALANÇO DE NITROGÊNIO …............................................................................. 70

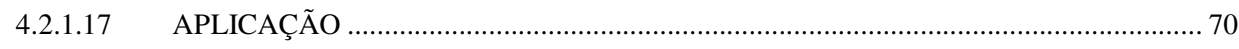

4.2.1.18 ESTIMATIVA DE PARÂMETROS ............................................................................... 70

4.2.1.19 APLICAÇÃO DOS DADOS EXPERIMENTAIS NO MODELO ADM1 ...................... 72

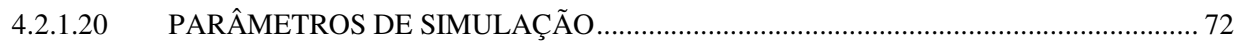

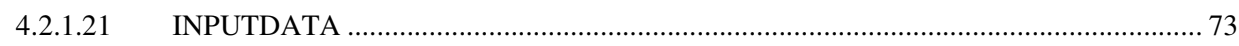

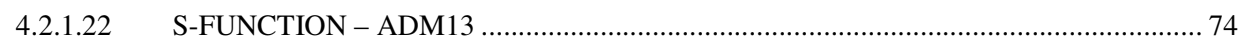

4.3 MODELO MATEMÁTICO SIMPLIFICADO APRIMORADO (MMS) .........................74

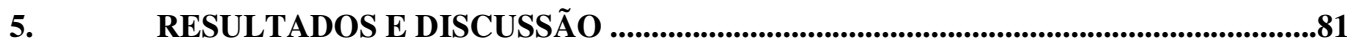

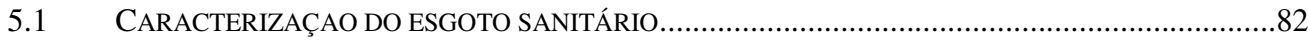

5.2 OPERAÇÃO DO REATOR UASB (146 L) - ETAPA I; ....................................................8

5.3 OPERAÇÃO DO REATOR UASB (160 L) - ETAPA II; ....................................................95

5.4 INFLUÊNCIA DA VARIAÇÃO SENOIDAL CÍCLICA DA VAZÃO MÉDIA AFLUENTE EM 40\% NO COMPORTAMENTO DO REATOR UASB (160 L) - ETAPA III; ............................................102

5.5 INFLUÊNCIA DA VARIAÇÃO SENOIDAL CÍCLICA DA VAZÃO MÉDIA AFLUENTE EM 60\% NO COMPORTAMENTO DO REATOR UASB (160 L) - ETAPA IV; ...........................................111

5.6 COMPARAÇÃO ENTRE AS ETAPAS DE OPERAÇÃO ...........................................119

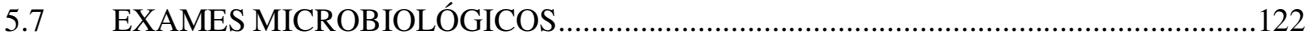

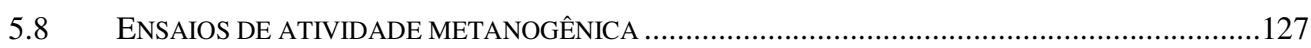

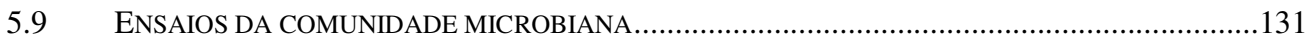

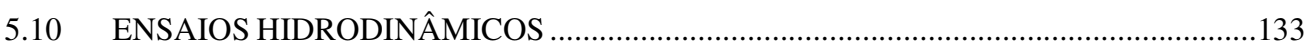

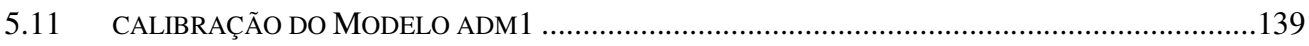

5.12 CALIBRAÇÃO E VALIDAÇÃO DO MODELO MMS ...........................................................150

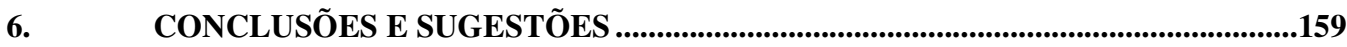

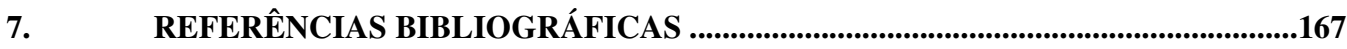


8. APÊNDICE .............................................................................................................180

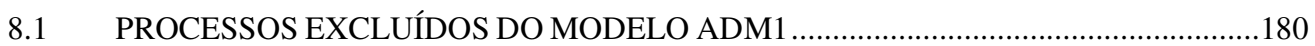

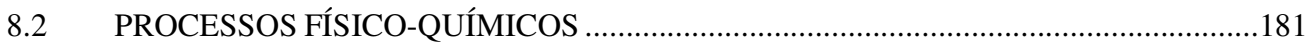

8.3 ROTINA COMPUTACIONAL DO MODELO MMS ………..........................................191 


\section{LISTA DE FIGURAS}

Figura 1. a) Reator UASB e pontos de coleta de amostras. b) Sistema de coleta de gás. c) Medidor de biogás.....................................................................36

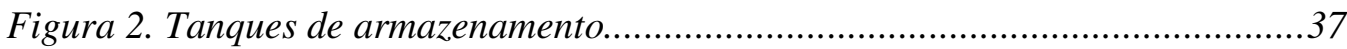

Figura 3. Reator UASB com novo separador de fases ............................................38

Figura 4. Lodo anaeróbio granular utilizado como inóculo ..................................40

Figura 5. Variações senoidais da vazão média afluente com amplitudes de $40 \%$ e de $60 \%$

Figura 6. Seqüência de processos da digestão anaeróbia de macro moléculas complexas. Fonte: adaptado de Batstone et al. $(2002 a, b)$........................53

Figura 7. Representação visual em Matlab/Simulink do modelo ADM1 .................72

Figura 8. Dados de entrada do modelo ADM1 .....................................................73

Figura 9. Esquema conceitual do reator UASB (a) e das conversões do substrato (b) para desenvolvimento do modelo matemático $\left(S_{C}\right.$ é a concentração de substrato solúvel e $X_{B}$ a concentração da biomassa ativa). Fonte: adaptado de Dochain e Vanrolleghem (2001) ................................................... 76

Figura 10. Valores de DQO para os componentes do substrato $\left(500 \mathrm{mg} . \mathrm{L}^{-1}\right)$, sendo: E-extrato de carne em pasta; $A$ - amido de milho; $A+E$ - solução de amido de milho e extrato de carne; $A+E+O+D$ - solução de amido de milho, extrato de carne, óleo e detergente .... .83

Figura 11. Perfil temporal de degradação média de DQO nos tanques de armazenamento

Figura 12. Fluxograma da distribuição percentual da concentração de sólidos no afluente do reator $U A S B$.

Figura 13. Caracterização do substrato (média horária) do reator UASB: a) pH, b) alcalinidade a bicarbonato, c) DQO bruta, d) DQO filtrada, e) concentração de sólidos totais, f) concentração de sólidos suspensos totais. *O tempo 0 dos gráficos corresponde às 9 h. 86

Figura 14. Resultados do perfil temporal de $24 \mathrm{~h}$ do reator: a) $\mathrm{pH}$, b) alcalinidade a bicarbonato, c) concentração de ácidos voláteis, d) DQO bruta, e) DQO filtrada, f) concentração de sólidos suspensos totais, $g$ ) concentração de 
sólidos suspensos voláteis, $h$ ) relação SSV/SST (ETAPA I - TDH $=8 h$;

Vasc $\left.=0,26 m \cdot h^{-1}\right)$. *O tempo 0 dos gráficos corresponde às $9 h$.

Figura 15. Resultados do perfil de 24 h de amostragem temporal do reator a) $\mathrm{pH}, \mathrm{b}$ ) alcalinidade a bicarbonato, c) concentração de ácidos voláteis, d) DQO bruta, e) DQO filtrada, f) concentração de sólidos suspensos totais, g) concentração de sólidos suspensos voláteis, h) relação SSV/SST (ETAPA I $-T D H=8 h ;$ Vasc $\left.=0,26 m \cdot h^{-1}\right)$. $O$ tempo 0 dos gráficos corresponde às $9 h$.

Figura 16. Resultados do perfil de 24 h de amostragem temporal do reator no dia $304^{\circ}$ dia a) $\mathrm{pH}$, b) alcalinidade a bicarbonato, c) concentração de ácidos voláteis, d) DQO bruta, e) DQO filtrada, f) concentração de sólidos suspensos totais, $g$ ) concentração de sólidos suspensos voláteis, $h$ ) relação SSV/SST. (ETAPA II-TDH = 10h; Vasc $\left.=0,23 \mathrm{~m} \cdot \mathrm{h}^{-1}\right)$. * tempo 0 dos gráficos corresponde às $9 h$.

Figura 17. Resultados do perfil de 24 h de amostragem temporal do reator no dia $309^{\circ}$ a) $\mathrm{pH}$, b) alcalinidade a bicarbonato, c) concentração de ácidos voláteis, d) DQO bruta, e) DQO filtrada, f) concentração de sólidos suspensos totais, $g$ ) concentração de sólidos suspensos voláteis, $h$ ) relação SSV/SST. (ETAPA II- TDH = 8h; Vasc $\left.=0,23 \mathrm{~m} \cdot \mathrm{h}^{-1}\right)$. *O tempo 0 dos gráficos corresponde às $9 h$. 100

Figura 18. Resultados do perfil de 24 h de amostragem temporal do reator no dia $320^{\circ}$ a) pH, b) alcalinidade a bicarbonato, c) concentração de ácidos voláteis, d) DQO bruta, e) DQO filtrada, f) concentração de SST, g) concentração de SSV, h) relação SSV/SST, i) carga orgânica, j) relação COe/COa $($ ETAPA III - TDH e Vasc = variável $) . *$ tempo 0 dos gráficos corresponde às $8 h$. 104

Figura 19. Resultados do perfil de 24 h de amostragem temporal do reator do dia $344^{\circ}$ a) pH, b) alcalinidade a bicarbonato, c) concentração de ácidos voláteis, d) DQO bruta, e) DQO filtrada, f) concentração de SST, g) concentração de SSV, h) relação SSV/SST (ETAPA III- TDH e Vasc = variável)*O tempo 0 dos gráficos corresponde às 9 h 
Figura 20. Resultados do perfil de 24 h de amostragem temporal do reator no dia $349^{\circ}$ a) $\mathrm{pH}, \mathrm{b}$ ) alcalinidade a bicarbonato, c) concentração de ácidos voláteis, d) DQO bruta, e) DQO filtrada, f) concentração de sólidos suspensos totais, $g$ ) concentração de sólidos suspensos voláteis, $h$ ) relação SSV/SST, i) carga orgânica, j) relação COe/COa (ETAPA IV-TDH e Vasc = variável). $*$ O tempo 0 dos gráficos corresponde às 9 h. 112

Figura 21. Resultados do perfil de 24 h de amostragem temporal do reator do dia $370^{\circ}$ a) $\mathrm{pH}, \mathrm{b}$ ) alcalinidade a bicarbonato, c) concentração de ácidos voláteis, d) DQO bruta, e) DQO filtrada, f) concentração de sólidos suspensos totais, $g$ ) concentração de sólidos suspensos voláteis, h) relação SSV/SST $($ ETAPA IV - TDH e Vasc = variável $)$. O tempo 0 dos gráficos corresponde às $9 h$.

Figura 22. Comparação entre os perfis de $24 \mathrm{~h}$ de amostragem temporal do reator operado com vazão média afluente (Qméd) e submetido a variações de vazão de 40\% (40\%*Qméd) e de 60\% (60\%*Qméd). a) pH, b) alcalinidade a bicarbonato, c) concentração de ácidos voláteis, d) DQO afluente, e) concentração de sólidos suspensos, $f$ ) produção de gás metano $\left(\mathrm{CH}_{4}\right)$. ${ }^{*} \mathrm{O}$ tempo 0 dos gráficos corresponde às $9 \mathrm{~h} ;(a),(e)$ e $(\mathrm{g})$ correspondem a afluente, efluente e gás.

Figura 23. Fotomicrografia das principais morfologias do inóculo do reator UASB:

a) arquéias metanogênicas semelhantes a Methanosaeta sp.; b) aglomerado de cocos; (c), d), e) e f) bacilos, filamentos e cocos . 124

Figura 24. Fotomicrografia das principais morfologias encontrados nos grânulos do lodo no $286^{\circ}$ dia de operação do reator UASB: a) arquéias metanogênicas semelhantes a Methanosaeta sp., bacilos, vibrios, cocos; b) bacilos fluorescentes; c) aglomerado de cocos e bacilos; d) bacilos com incrustações, e) espirilo, vibrios, bacilos; f) arquéias metanogênicas semelhantes a Metanosarcina sp. 125

Figura 25. Fotomicrografia das principais morfologias encontradas nos grânulos do lodo no $342^{\circ}$ dia de operação do reator UASB: a) espirilo; b) filamentos; c) bacilos; d) bacilos em cadeia 126 
Figura 26. Fotomicrografia das principais morfologias encontradas nos grânulos do lodo no $372^{\circ}$ dia de operação do reator. a) bacilos; b) arquéias metanogênicas semelhantes a Metanosaeta sp.; c) filamentos, cocos, vibrios, bacilos; d) cocos e bacilos

Figura 27. Pontos de coleta do reator UASB utilizados nos ensaios de AME ........128

Figura 28. Fotomicrografia das morfologias predominantes na população microbiana presente em três alturas (Ualt1, 2 e 3) do reator UASB em três condições operacionais ( $Q_{\text {constante }}, Q_{40 \%}$ e $\left.Q_{60 \%}\right)$ : a) bacilos, espirilos e vibrios; b) arquéias metanogênicas semelhantes ao gênero Methanosarcina sp.; c) bacilos, cocos, arquéias metanogênicas semelhantes ao gênero Methanosaeta sp.; d) bacilos fluorescentes. Aumento 1500x. 129

Figura 29. Perfil de bandas no DGGE com primers para o domínio Archaea (1100 FGC e 1400 R) das populações microbianas presentes em três pontos do reator em três condições operacionais $\left(Q_{\text {constante, }} Q_{40 \%}\right.$ e $\left.Q_{60 \%}\right)$. Os pontos 2 , 3 e 4 correspondem aos pontos de coleta 1, 2 e 3

Figura 30. Perfil de bandas no DGGE com primers para o domínio Bacteria (968 FGC e 1392 R) das populações microbianas presentes em três pontos do reator UASB em três condições operacionais $\left(Q_{\text {constante, }} Q_{40 \%}\right.$ e $\left.Q_{60 \%}\right)$. Os pontos 2, 3 e 4 correspondem aos pontos de coleta 1, 2 e 3 .

Figura 31. Curvas de variação da concentração de eosina Y ao longo do tempo nas amostras do efluente do reator para os ensaios de estímulo-resposta: vazão afluente constante - a) ensaio 1; b) ensaio 2; variação de $40 \%$ da vazão afluente - c) ensaio 3; d) ensaio 4; variação de $60 \%$ da vazão afluente - e) ensaio 5 134

Figura 32. Curvas de DTR obtidas experimentalmente com uso de eosina Y em diferentes condições operacionais do reator UASB: vazão afluente constante - a) ensaio 1; b) ensaio 2; variação de $40 \%$ da vazão afluente - c) ensaio 3; d) ensaio 4; variação de $60 \%$ da vazão afluente - e) ensaio 5. -dados experimentais; $\quad$-----pequena dispersão; $-N$-CSTR em série;

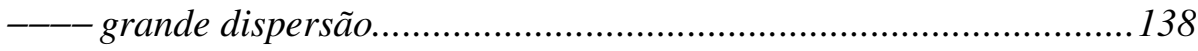

Figura 33. Procedimento de estimativa para identificação de parâmetros ............. 140 
Figura 34. Valores de a) DQO bruta, b) pH, c) concentração de ácidos voláteis, d) alcalinidade a bicarbonato dos resultados observados e calculados (calc 1 - $\theta c=0,4 d$; calc 2 - $\theta c=50 d$; calc $3-\theta c=100 d$ ) para o efluente $\ldots . .148$

Figura 35. Resultados da variação de DQO efluente ao longo do tempo observados e calculados nos perfis de $24 \mathrm{~h}$ de amostragem temporal do reator: ETAPAS I e II (TDH e Vasc = constante) a) perfil 1; b) perfil 2; c) perfil 3 153

Figura 36. Resultados da variação de DQO efluente ao longo do tempo observados e calculados nos perfis de $24 \mathrm{~h}$ de amostragem temporal do reator: ETAPAS I e II (TDH e Vasc = constante $)$ a) perfil 4; ETAPA III (TDH, Vasc variável, 40\%Q) b) perfil 6; ETAPA IV c) perfil 8 ................................ 154

Figura 37. Resultados da variação de DQO efluente ao longo do tempo observados e calculados nos perfis de 24 h de amostragem temporal do reator: a) perfil $1\left(\mathrm{TDH}=6 \mathrm{~h} ;\right.$ Vasc $\left.\left.=0,78 \mathrm{~m} \cdot \mathrm{h}^{-1}\right) ; \mathrm{b}\right)$ perfil $2(\mathrm{TDH}=6 \mathrm{~h}$, Vasc $=1,71$ $\left.m . h^{-1}, q r=50 \% Q\right)$ 157 


\section{LISTA DE TABELAS}

Tabela 1. Algumas vantagens e desvantagens dos processos anaeróbios (reator UASB) em relação aos processos aeróbios convencionais 5

Tabela 2. Aplicações de reatores UASB no tratamento de esgotos sanitários .............6

Tabela 3. Composição do esgoto sintético para DQO média igual a $300 \mathrm{mg} . L^{-1}$.......39

Tabela 4. Etapas de operação do reator UASB ....................................................41

Tabela 5. Parâmetros analisados, seus respectivos métodos e metodologia utilizada45

Tabela 6. Parâmetros analisados e suas freqüências (partida do reator).... .45

Tabela 7. Características dos ensaios de estímulo-resposta realizados no reator

$U A S B$ 50

Tabela 8. Modelos hidrodinâmicos uniparamétricos de dispersão (LEVENSPIEL, 1999). 51

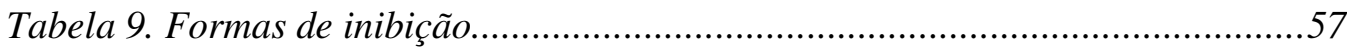

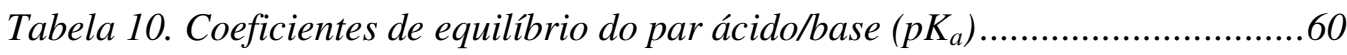

Tabela 11. Coeficientes bioquímicos $\left(v_{i} j\right)$ e equações cinéticas $\left(\rho_{j}\right)$ para os compostos solúveis $(i=1-12 ; j=1-19)$

Tabela 12. Coeficientes bioquímicos $\left(v_{i} j\right)$ e equações cinéticas $\left(\rho_{j}\right)$ para os compostos particulados $(i=13-24 ; j=1-19)$.

Tabela 13. Equações de balanço de massa dos compartimentos 1 a 4 .77

Tabela 14. Simbologia empregada, valores numéricos dos parâmetros do modelo e

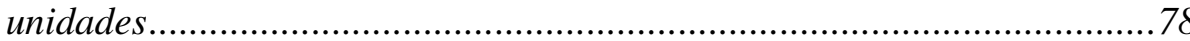

Tabela 15. Equações de balanço de massa dos compartimentos 1 a 4 ......................79

Tabela 16. Simbologia empregada, valores numéricos dos parâmetros do modelo e unidades..... .80

Tabela 17. Características do esgoto sanitário e do substrato afluente ao reator UASB (monitoramento) 84

Tabela 18. Composição típica do esgoto sanitário 85

Tabela 19. Resumo das características do substrato do reator UASB (perfis temporais de amostragem - 1 a 8 ) 
Tabela 20. Resumo dos resultados obtidos no perfil de $24 \mathrm{~h}$ do $181^{\circ}$ dia de operação

$$
\left(\text { ETAPA I-TDH }=8 h ; \text { Vasc }=0,26 m \cdot h^{-1}\right) .
$$

Tabela 21. Resumo dos resultados obtidos no perfil de $24 \mathrm{~h}$ do $189^{\circ}$ dia de operação

$$
\left(\text { ETAPA I-TDH }=8 h ; \text { Vasc }=0,26 m \cdot h^{-1}\right) \text {. }
$$

Tabela 22. Resumo dos resultados obtidos no perfil de 24 h do $304^{\circ}$ dia de operação

$$
\left(\text { ETAPA II }- \text { TDH }=10 h ; \text { Vasc }=0,23 m \cdot h^{-1}\right)
$$

Tabela 23. Resumo dos resultados obtidos no perfil de $24 \mathrm{~h}$ do $309^{\circ}$ dia de operação

$$
\left(\text { ETAPA II }- \text { TDH }=10 h ; \text { Vasc }=0,23 \mathrm{~m} \cdot \mathrm{h}^{-1}\right)
$$

Tabela 24. Resumo dos resultados obtidos no perfil de 24 h do $320^{\circ}$ dia de operação $($ ETAPA III - TDH e Vasc $=$ variável $)$

Tabela 25. Resumo dos resultados obtidos no perfil de $24 \mathrm{~h}$ do $344^{\circ}$ dia de operação

$$
(\text { ETAPA III - TDH e Vasc }=\text { variável }) .
$$

Tabela 26. Resumo dos resultados obtidos no perfil de 24 h do $349^{\circ}$ dia de operação

$($ ETAPA III - TDH e Vasc = variável $)$

Tabela 27. Resumo dos resultados obtidos no perfil de 24 h do $370^{\circ}$ dia de operação $($ ETAPA III - TDH e Vasc = variável $)$ 119

Tabela 28. Resumo dos resultados obtidos nos perfis de 24 h dos dias $304^{\circ}$, $344^{\circ} \mathrm{e}$

$370^{\circ}$ de operação (ETAPAS I, II e III) 120

Tabela 29. Atividade metanogênica aparente (AMA), atividade metanogênica específica (AME) e atividade no controle $\pm \mathrm{DV}\left(\mathrm{em} \mathrm{mmolCH} 4 . \mathrm{g}^{-1} S V \cdot d^{-1}\right)$ encontradas para as populações microbianas presentes em três pontos do reator UASB operado em diferentes condições operacionais ( $Q_{\text {constante, }} Q_{40 \%}$ $\left.e Q_{60 \%}\right)$

Tabela 30. Eficiências alcançadas pelo reator UASB tratando substrato nas três condições operacionais: vazão média afluente constante $\left(Q_{\text {constante }}\right)$, variação senoidal da vazão média afluente em $40 \%\left(Q_{40 \%}\right)$ e em $60 \%$ $\left(Q_{60 \%}\right)$

Tabela 31. Parâmetros obtidos com o ajuste dos dados experimentais para reator $U A S B$ 136

Tabela 32. Coeficientes de correlação obtidos com o ajuste dos resultados experimentais pelos modelos teóricos

Tabela 33. Parâmetros estequiométricos (calculados e sugeridos) 141 
Tabela 34. Estimativa dos conteúdos de carbono e de nitrogênio presentes na composição do substrato ........................................................................... 142

Tabela 35. Valores de parâmetros sugeridos por Batstone et al. $(2002 a, b)$.......... 143

Tabela 36. Valores e unidades das variáveis de estado do substrato (afluente) e do efluente (vetor de inicialização)......................................................... 144

Tabela 37. Condições operacionais aplicadas nas simulações do ADM1, resultados observados (experimentalmente) e calculados nas simulações. 145

Tabela 38. Equações da variação de DQO ao longo do tempo, coeficientes de

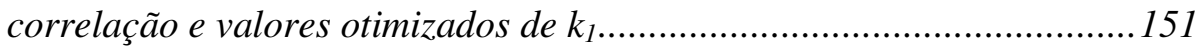

Tabela 39. Resumo do conjunto de valores de DQO efluente (observado e calculado) ao longo do tempo nos perfis 1, 2, 3, 4, 6 e 8 . 156

Tabela 40. Equações da variação de DQO ao longo do tempo, coeficientes de correlação e valores otimizados de $k_{1}$ para dados de Passig (2005) .......156

Tabela 41. Resumo do conjunto de valores de DQO efluente observado e calculado) ao longo do tempo nos perfis 1 e 2 ......................................................... 158

Tabela 42. Rotina do arquivo reator.m do modelo MMS ...................................... 192

Tabela 43. Rotina do arquivo reator 16.m do modelo MMS .................................. 193 


\section{LISTA DE SÍMBOLOS E ABREVIATURAS}

\begin{tabular}{|c|c|}
\hline Ac- & Íon acetato \\
\hline ADM1 & Anaerobic Digestion Model no 1 \\
\hline $\mathrm{AGV}$ & Ácidos graxos voláteis, [M].[L]-3 \\
\hline AME & Atividade metanogênica específica \\
\hline ASM1 & Anaerobic Sludge Model 1 \\
\hline $\mathrm{Bu}-$ & Íon butirato \\
\hline $\mathrm{C}(\mathrm{t})$ & Curvas experimentais de concentração \\
\hline $\mathrm{Ca}^{2+}$ & Íon cálcio \\
\hline $\mathrm{CaCO}_{3}$ & Carbonato de cálcio, $[\mathrm{M}] \cdot\left[\mathrm{L}^{-3}\right]$ \\
\hline $\mathrm{Cl}-$ & Íon de cloro \\
\hline $\mathrm{CO} 2$ & Gás carbônico \\
\hline $\mathrm{CH} 4$ & Gás metano \\
\hline C_su & Conteúdo de carbono presente nos monossacarídeos, $[\mathrm{mol} \mathrm{C}] .\left[\mathrm{L}^{-3}\right]$ \\
\hline C_aa & Conteúdo de carbono presente nos aminoácidos, $[\mathrm{mol} \mathrm{C}] .\left[\mathrm{L}^{-3}\right]$ \\
\hline C_fa & Conteúdo de carbono presente nos ácidos graxos, $[\mathrm{mol} \mathrm{C}] \cdot\left[\mathrm{L}^{-3}\right]$ \\
\hline C_va & Conteúdo de carbono presente no valerato, $[\mathrm{mol} \mathrm{C}] \cdot\left[\mathrm{L}^{-3}\right]$ \\
\hline C_bu & Conteúdo de carbono presente no butirato, $[\mathrm{mol} \mathrm{C}] \cdot\left[\mathrm{L}^{-3}\right]$ \\
\hline C_pro & Conteúdo de carbono presente no propionato, $[\mathrm{mol} \mathrm{C}] \cdot\left[\mathrm{L}^{-3}\right]$ \\
\hline C_ac & Conteúdo de carbono presente no acetato, $[\mathrm{mol} \mathrm{C}] \cdot\left[\mathrm{L}^{-3}\right]$ \\
\hline C_ch4 & Conteúdo de carbono presente no metano, $[\mathrm{mol} \mathrm{C}] \cdot\left[\mathrm{L}^{-3}\right]$ \\
\hline C_sI & Conteúdo de carbono presente nos inertes solúveis, $[\mathrm{mol} \mathrm{C}] \cdot\left[\mathrm{L}^{-3}\right]$ \\
\hline C_xc & Conteúdo de carbono presente nos compostos particulados, $[\mathrm{mol} \mathrm{C}] .\left[\mathrm{L}^{-3}\right]$ \\
\hline C_ch & Conteúdo de carbono presente nos carboidratos, $[\mathrm{mol} \mathrm{C}] \cdot\left[\mathrm{L}^{-3}\right]$ \\
\hline C_pr & Conteúdo de carbono presente nas preteínas, $[\mathrm{mol} \mathrm{C}] .\left[\mathrm{L}^{-3}\right]$ \\
\hline C_li & Conteúdo de carbono presente nos lipídeos, $[\mathrm{mol} \mathrm{C}] \cdot\left[\mathrm{L}^{-3}\right]$ \\
\hline C_bac & Conteúdo de carbono presente nos microrganismos, $[\mathrm{mol} \mathrm{C}] \cdot\left[\mathrm{L}^{-3}\right]$ \\
\hline C_xI & Conteúdo de carbono presente nos inertes particulados, $[\mathrm{mol} \mathrm{C}] \cdot\left[\mathrm{L}^{-3}\right]$ \\
\hline DBO & Demanda Bioquímica de Oxigênio, $[\mathrm{M}] \cdot\left[\mathrm{L}^{-3}\right]$ \\
\hline DGGE & Denaturing gel eletrophoresis gradient \\
\hline DQO & Demanda Química de Oxigênio, $[\mathrm{M}] \cdot\left[\mathrm{L}^{-3}\right]$ \\
\hline DNA & Ácido dezoxiribonucléico \\
\hline DNAr 16S & Ácido dezoxiribonucléico \\
\hline $\mathrm{E} \square$ & Curvas de distribuição do tempo de detenção hidráulica \\
\hline
\end{tabular}




\begin{tabular}{|c|c|}
\hline EDO & Equações diferenciais ordinárias \\
\hline EESC & Escola de Engenharia de São Carlos \\
\hline f_sI_xc & parcela de material inerte solúvel nos compostos \\
\hline f_xI_xc & parcela de material inerte particulado nos compostos \\
\hline f_bu_su & parcela de butirato proveniente dos monossacarídeos \\
\hline f_li_xc & parcela de lipídeos nos compostos \\
\hline f_h2_su & parcela de hidrogênio proveniente dos monossacarídeos \\
\hline f_pr_xc & parcela de proteínas nos compostos \\
\hline f_ch_xc & parcela de carboidratos nos compostos \\
\hline f_fa_li & parcela de ácidos graxos proveniente dos lipídeos \\
\hline f_h2_aa & parcela de hidrogênio proveniente dos aminoácidos \\
\hline f_va_aa & parcela de valerato proveniente dos aminoácidos \\
\hline f_pro_aa & parcela de propionato proveniente dos aminoácidos \\
\hline f_ac_aa & parcela de acetato proveniente dos aminoácidos \\
\hline f_pro_su & parcela de propionato proveniente dos monossacarídeos \\
\hline f_ac_su & parcela de acetato proveniente dos monossacarídeos \\
\hline f_bu_aa & parcela de butirato proveniente dos aminoácidos \\
\hline GD & Modelo teórico uniparamétrico de grande intensidade \\
\hline HAc & Ácido Acético, $[\mathrm{M}] \cdot\left[\mathrm{L}^{-3}\right]$ \\
\hline $\mathrm{HBu}$ & Ácido Butírico, $[\mathrm{M}] \cdot\left[\mathrm{L}^{-3}\right]$ \\
\hline $\mathrm{HCO}^{-}$ & Bicarbonato \\
\hline $\mathrm{HPr}$ & Ácido Propiônico, $[\mathrm{M}] .\left[\mathrm{L}^{-3}\right]$ \\
\hline $\mathrm{HVa}$ & Ácido Valérico, $[\mathrm{M}] \cdot\left[\mathrm{L}^{-3}\right]$ \\
\hline $\mathrm{H} 2$ & Gás hidrogênio \\
\hline $\mathrm{H} 2 \mathrm{~S}$ & Gás sulfídrico \\
\hline HS & Ácido sulfúrico \\
\hline IQWA & International Quality Water Association \\
\hline IWA & International Water Association \\
\hline $\mathrm{K}$ & Matriz pseudo-estacionária \\
\hline K_a_va & coeficiente de equilíbrio ácido/base, $[\mathrm{mol}] .\left[\mathrm{L}^{-3}\right]$ \\
\hline K_a_bu & coeficiente de equilíbrio ácido/base, $[\mathrm{mol}] .\left[\mathrm{L}^{-3}\right]$ \\
\hline K_a_pro & coeficiente de equilíbrio ácido/base, $[\mathrm{mol}] .\left[\mathrm{L}^{-3}\right]$ \\
\hline K_a_ac & coeficiente de equilíbrio ácido/base, $[\mathrm{mol}] .\left[\mathrm{L}^{-3}\right]$ \\
\hline K_a_co2 & coeficiente de equilíbrio ácido/base, $[\mathrm{mol}] .\left[\mathrm{L}^{-3}\right]$ \\
\hline K_a_IN & coeficiente de equilíbrio ácido/base, $[\mathrm{mol}] .\left[\mathrm{L}^{-3}\right]$ \\
\hline
\end{tabular}




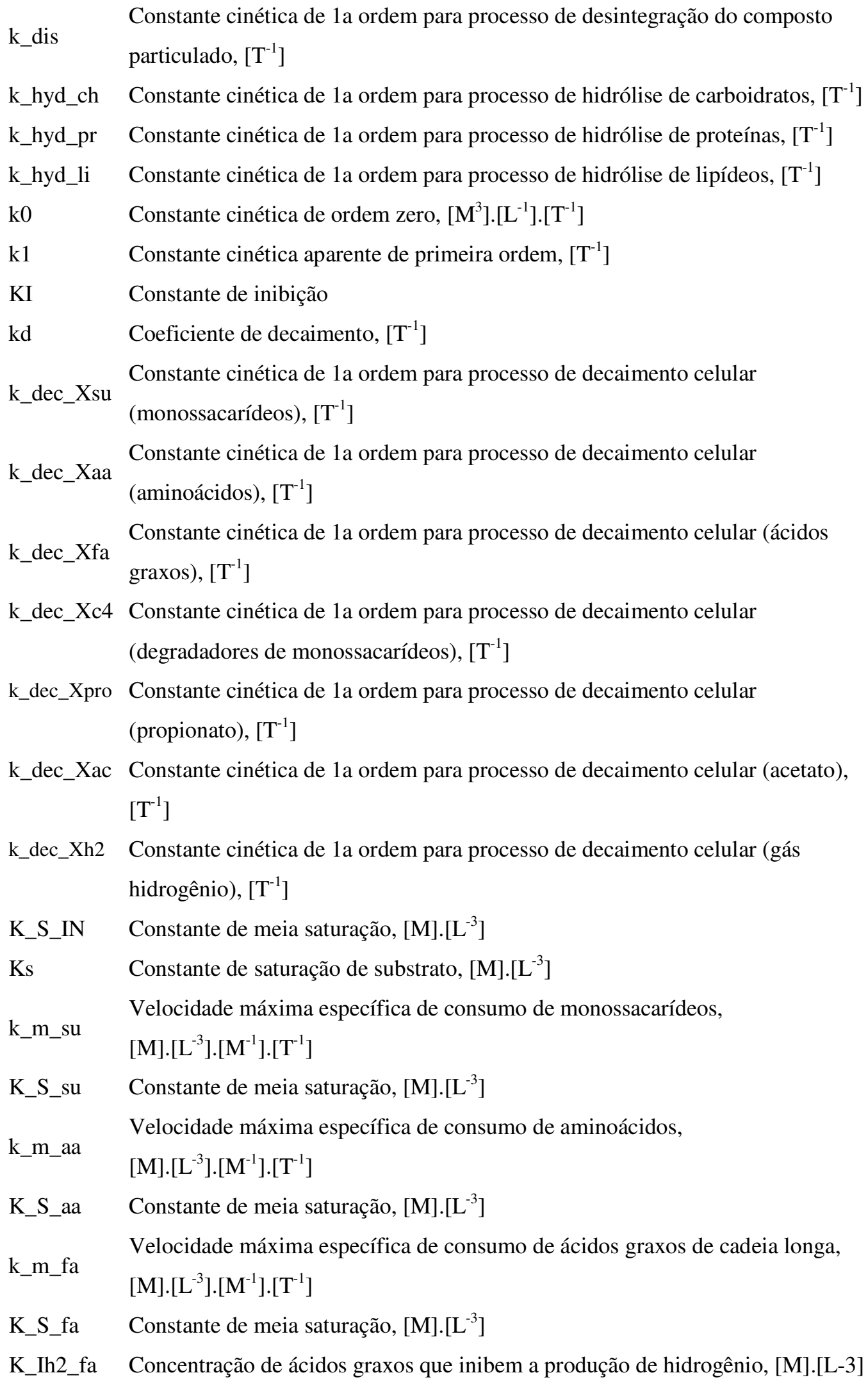




\begin{tabular}{|c|c|}
\hline k_m_c4 & $\begin{array}{l}\text { Velocidade máxima específica de consumo de valerato e butirato, } \\
{[\mathrm{M}] \cdot\left[\mathrm{L}^{-3}\right] \cdot\left[\mathrm{M}^{-1}\right] \cdot\left[\mathrm{T}^{-1}\right]}\end{array}$ \\
\hline K_S_c4 & Constante de meia saturação, $[\mathrm{M}] \cdot\left[\mathrm{L}^{-3}\right]$ \\
\hline K_Ih2_c4 & Concentração de ácidos graxos que inibem a produção de hidrogênio, $[\mathrm{M}] \cdot\left[\mathrm{L}^{-3}\right]$ \\
\hline k_m_pro & Velocidade máxima específica de consumo de propionato, $[\mathrm{M}] \cdot\left[\mathrm{L}^{-3}\right] \cdot\left[\mathrm{M}^{-1}\right] \cdot\left[\mathrm{T}^{-1}\right]$ \\
\hline K_S_pro & Constante de meia saturação, [M].[L-3] \\
\hline K_Ih2_pro & Concentração de ácidos graxos que inibem a produção de hidrogênio, $[\mathrm{M}] .\left[\mathrm{L}^{-3}\right]$ \\
\hline k_m_ac & Velocidade máxima específica de consumo de acetato, $[\mathrm{M}] \cdot\left[\mathrm{L}^{-3}\right] \cdot\left[\mathrm{M}^{-1}\right] \cdot\left[\mathrm{T}^{-1}\right]$ \\
\hline K_S_ac & Constante de meia saturação, $[\mathrm{M}] \cdot\left[\mathrm{L}^{-3}\right]$ \\
\hline K_I_nh3 & Concentração de ácidos graxos que inibem a produção de hidrogênio, $[\mathrm{M}] .\left[\mathrm{L}^{-3}\right]$ \\
\hline k_m_h2 & $\begin{array}{l}\text { Velocidade máxima específica de consumo de hidrogênio, } \\
{[\mathrm{M}] \cdot\left[\mathrm{L}^{-3}\right] \cdot\left[\mathrm{M}^{-1}\right] \cdot\left[\mathrm{T}^{-1}\right]}\end{array}$ \\
\hline K_S_h2 & Constante de meia saturação, $[\mathrm{M}] \cdot\left[\mathrm{L}^{-3}\right]$ \\
\hline K_H_co2 & coeficiente da Lei de Henry, $[\mathrm{mol}] \cdot\left[\mathrm{L}^{-3}\right] \cdot\left[\mathrm{bar}^{-1}\right]$ \\
\hline K_H_ch4 & coeficiente da Lei de Henry, $[\mathrm{mol}] \cdot\left[\mathrm{L}^{-3}\right] \cdot\left[\mathrm{bar}^{-1}\right]$ \\
\hline K_H_h2 & coeficiente da Lei de Henry, $[\mathrm{mol}] .\left[\mathrm{L}^{-3}\right] \cdot\left[\mathrm{bar}^{-1}\right]$ \\
\hline $\mathrm{kLa}$ & coeficiente de transferência gás-líquido, $\left[\mathrm{T}^{-1}\right]$ \\
\hline LPB & Laboratório de Processos Biológicos \\
\hline LTR & Laboratório de Tratamento de Resíduos \\
\hline MMS & Modelo Matemático Simplificado \\
\hline $\mathrm{Mg}^{2+}$ & Íon magnésio \\
\hline$M_{t}$ & Massa de substrato gerada/consumida por unidade de volume, $[\mathrm{M}] .\left[\mathrm{L}^{-3}\right]$ \\
\hline N-CSTR & Modelo teórico uniparamétrico de tanques em série \\
\hline $\mathrm{Na}+$ & Íon de sódio \\
\hline N_I & concentração de $\mathrm{N}$ no material inerte nos sistemas em batelada de lodo \\
\hline N_xc & concentração de $\mathrm{N}$ nos compostos e material inerte \\
\hline N_aa & concentração de $\mathrm{N}$ nos aminoácidos e em parte das proteínas \\
\hline N_bac & concentração de $\mathrm{N}$ na biomassa no sistema de lodo em batelada \\
\hline $\mathrm{NaOH}$ & Hidróxido de sódio \\
\hline $\mathrm{NH}_{3}$ & Amônia \\
\hline $\mathrm{N}-\mathrm{NH}_{4}+$ & Nitrogênio amoniacal, $[\mathrm{M}] \cdot\left[\mathrm{L}^{-3}\right]$ \\
\hline N-NTK & Nitrogênio total, $[\mathrm{M}] \cdot\left[\mathrm{L}^{-3}\right]$ \\
\hline PABR & Reator anaeróbio compartimentado \\
\hline PD & Modelo teórico uniparamétrico de pequena dispersão \\
\hline PCP & Pentaclorofenol, $[\mathrm{M}] \cdot\left[\mathrm{T}^{-1}\right]$ \\
\hline
\end{tabular}




\begin{tabular}{|c|c|}
\hline PCR & Polymerase Chain Reaction \\
\hline pH_UL_aa & Limite superior da inibição por pH no consumo de aminoácidos \\
\hline pH_LL_aa & Limite inferior da inibição por $\mathrm{pH}$ no consumo de aminoácidos \\
\hline pH_UL_ac & Limite superior da inibição por $\mathrm{pH}$ no consumo de acetato \\
\hline pH_LL_ac & Limite inferior da inibição por $\mathrm{pH}$ no consumo de acetato \\
\hline pH_UL_h2 & Limite superior da inibição por $\mathrm{pH}$ no consumo de hidrogênio \\
\hline pH_LL_h2 & Limite inferior da inibição por $\mathrm{pH}$ no consumo de hidrogênio \\
\hline P_gas_h2 & pressão parcial de gás hidrogênio, [bar] \\
\hline P_gas_ch4 & pressão parcial de gás metano, [bar] \\
\hline P_gas_co2 & pressão parcial de gás carbônico, [bar] \\
\hline $\mathrm{pH}$ & Potencial hidrogeniônico \\
\hline Pr- & Íon propionato \\
\hline P_atm & pressão atmosférica, [bar] \\
\hline p_gas_h2o & pressão de vapor de água, [bar] \\
\hline $\mathrm{Q}, q$ & Vazão média afluente, $\left[\mathrm{M}^{3}\right] \cdot\left[\mathrm{T}^{-1}\right]$ \\
\hline $\bar{Q}$ & Vazão média afluente, $\left[\mathrm{M}^{3}\right] \cdot\left[\mathrm{T}^{-1}\right]$ \\
\hline$Q_{i n}$ & Vazão afluente, $\left[\mathrm{M}^{3}\right] \cdot\left[\mathrm{T}^{-1}\right]$ \\
\hline$Q_{\text {out }}$ & Vazão efluente, $\left[\mathrm{M}^{3}\right] \cdot\left[\mathrm{T}^{-1}\right]$ \\
\hline $\mathrm{R}^{2}$ & Coeficiente de correlação (adimensional) \\
\hline$(-r a)$ & Termo cinético dependente do tipo de modelo cinético empregado \\
\hline $\mathrm{R}$ & constante da Lei dos Gases, $[$ bar $] \cdot\left[\mathrm{L}^{3}\right] \cdot\left[\mathrm{mol}^{-1}\right] \cdot\left[\mathrm{T}^{-1}\right]$ \\
\hline RAFF & Reator anaeróbio de filme fixo \\
\hline RAHLF & Reator anaeróbio horizontal de leito fixo \\
\hline $\mathrm{RC}$ & Reator de controle \\
\hline SDT & Sólidos dissolvidos totais, [M].[L-3] \\
\hline SDV & Sólidos dissolvidos voláteis, $[\mathrm{M}] .\left[\mathrm{L}^{-3}\right]$ \\
\hline SDF & Sólidos dissolvidos fixos, $[\mathrm{M}] .\left[\mathrm{L}^{-3}\right]$ \\
\hline SS & Sólidos suspensos, $[\mathrm{M}] .\left[\mathrm{L}^{-3}\right]$ \\
\hline SSF & Sólidos suspensos fixos, $[\mathrm{M}] \cdot\left[\mathrm{L}^{-3}\right]$ \\
\hline SST & Sólidos suspensos totais, $[\mathrm{M}] \cdot\left[\mathrm{L}^{-3}\right]$ \\
\hline SSV & Sólidos suspensos voláteis, $[\mathrm{M}] \cdot\left[\mathrm{L}^{-3}\right]$ \\
\hline ST & Sólidos totais, $[\mathrm{M}] \cdot\left[\mathrm{L}^{-3}\right]$ \\
\hline STV & Sólidos totais voláteis, $[\mathrm{M}] \cdot\left[\mathrm{L}^{-3}\right]$ \\
\hline
\end{tabular}




\begin{tabular}{|c|c|}
\hline STF & Sólidos totais fixos, $[\mathrm{M}] \cdot\left[\mathrm{L}^{-3}\right]$ \\
\hline Ssu & Concentração de monossacarídeos na forma solúvel, $[\mathrm{M}] \cdot\left[\mathrm{L}^{-3}\right]$ \\
\hline Saa & Concentração de aminoácidos na forma solúvel, $[\mathrm{M}] \cdot\left[\mathrm{L}^{-3}\right]$ \\
\hline Sfa & Concentração de ácidos graxos na forma solúvel, $[\mathrm{M}] .\left[\mathrm{L}^{-3}\right]$ \\
\hline Sva & Concentração de ácido valérico na forma solúvel, $[\mathrm{M}] .\left[\mathrm{L}^{-3}\right]$ \\
\hline Sbu & Concentração de ácido butírico na forma solúvel, $[\mathrm{M}] .\left[\mathrm{L}^{-3}\right]$ \\
\hline Spro & Concentração de ácido propiônico na forma solúvel, $[\mathrm{M}] \cdot\left[\mathrm{L}^{-3}\right]$ \\
\hline $\mathrm{Sac}$ & Concentração de ácido acético na forma solúvel, $[\mathrm{M}] \cdot\left[\mathrm{L}^{-3}\right]$ \\
\hline Sh2 & Concentração de gás hidrogênio na forma líquida, $[\mathrm{M}] \cdot\left[\mathrm{L}^{-3}\right]$ \\
\hline $\mathrm{SCH} 4$ & Concentração de gás metano na forma líquida, $[\mathrm{M}] \cdot\left[\mathrm{L}^{-3}\right]$ \\
\hline SIC & Concentração de carbono inorgânico, $[\mathrm{mol}] \cdot\left[\mathrm{L}^{-3}\right]$ \\
\hline SIN & Concentração de nitrogênio inorgânico, $[\mathrm{mol}] \cdot\left[\mathrm{L}^{-3}\right]$ \\
\hline SI & Concentração de inertes, $[\mathrm{M}] \cdot\left[\mathrm{L}^{-3}\right]$ \\
\hline$t$ & Tempo, $[\mathrm{T}]$ \\
\hline $\mathrm{T}$ & Temperatura, $\left[{ }^{\circ} \mathrm{C}\right]$ \\
\hline Top & temperature de operação, [K] \\
\hline $\mathrm{T}$ & Período de ajuste de alimentação, $\left[\mathrm{T}^{-1}\right]$ \\
\hline TCO & Taxa de carregamento orgânica, $[\mathrm{M}] \cdot\left[\mathrm{L}^{-3}\right] \cdot\left[\mathrm{T}^{-1}\right]$ \\
\hline $\mathrm{TDH} / \theta \mathrm{h}$ & Tempo de detenção hidráulica, $\left[\mathrm{T}^{-1}\right]$ \\
\hline$\theta \mathrm{c}$ & Tempo de retenção celular, [T] \\
\hline TIC & Trocador iônico composto \\
\hline Teflon & Fibra de politetrafluoretano \\
\hline$\sigma_{\theta}^{2}$ & Variância \\
\hline UASB & Upflow Anaerobic Sludge Blanket \\
\hline$v$ ou $\mathrm{V}$ & volume do reator, $\left[\mathrm{L}^{3}\right]$ \\
\hline Va- & Íon valerato \\
\hline$\vec{V}$ & Velocidade do escoamento através da superfície de controle $[\mathrm{M}] .\left[\mathrm{L}^{-1}\right]$ \\
\hline V_liq & volume do reator, $\left[\mathrm{L}^{-1}\right]$ \\
\hline V_gas & volume do gás, $\left[\mathrm{L}^{-1}\right]$ \\
\hline Y & Coeficiente de conversão de biomassa (adimensional) \\
\hline Y_aa & produção de biomassa a partir de aminoácidos, $[\mathrm{M}] .\left[\mathrm{M}^{-1}\right]$ \\
\hline Y_fa & produção de biomassa a partir de ácidos graxos de cadeia longa, $[\mathrm{M}] .\left[\mathrm{M}^{-1}\right]$ \\
\hline Y_su & produção de biomassa a partir de monossacarídeos, $[\mathrm{M}] \cdot\left[\mathrm{M}^{-1}\right]$ \\
\hline Y_c4 & produção de biomassa a partir de valerato e butirato, $[\mathrm{M}] .\left[\mathrm{M}^{-1}\right]$ \\
\hline
\end{tabular}




\begin{tabular}{|c|c|}
\hline Y_pro & produção de biomassa a partir de propionato, $[\mathrm{M}] .\left[\mathrm{M}^{-1}\right]$ \\
\hline Y_ac & produção de biomassa a partir de acetato, $[\mathrm{M}] .\left[\mathrm{M}^{-1}\right]$ \\
\hline Y_h2 & produção de biomassa a partir de hidrogênio, $[\mathrm{M}] .\left[\mathrm{M}^{-1}\right]$ \\
\hline$\omega$ & Frequiência da variação da vazão, $\left[\mathrm{T}^{-1}\right]$ \\
\hline$\rho_{i n}$ & Massa específica do afluente, $[\mathrm{M}] \cdot\left[\mathrm{L}^{-3}\right]$ \\
\hline$\rho_{\text {out }}$ & Massa específica do efluente, $[\mathrm{M}] \cdot\left[\mathrm{L}^{-3}\right]$ \\
\hline$\theta$ & Tempo adimensional \\
\hline$\delta$ & Fator de retenção de biomassa \\
\hline$\lambda$ & Comprimento de onda, $[\mathrm{n}] .[\mathrm{L}]$ \\
\hline$\alpha$ & Metade da amplitude decimal relativa da variação da vazão, (adimensional) \\
\hline$\sum S_{C^{+}}$ & Concentração equivalente total de cátions, $[\mathrm{mol}] .\left[\mathrm{L}^{-3}\right]$ \\
\hline$\sum S_{A^{-}}$ & Concentração equivalente total de ânions, $[\mathrm{mol}] .\left[\mathrm{L}^{-3}\right]$ \\
\hline$S_{\mathrm{NH}_{4}^{+}}$ & Concentração de íon amônio, [mol N]. $\left[\mathrm{L}^{-3}\right]$ \\
\hline$S_{H^{+}}$ & Concentração de íon hidrogênio, $\left[\mathrm{mol} \mathrm{H+]} \cdot\left[\mathrm{L}^{-3}\right]\right.$ \\
\hline $\mathrm{S}_{\mathrm{HCO}_{3}^{-}}$ & Concentração de íon carbonato, $[\mathrm{mol} \mathrm{C}] \cdot\left[\mathrm{L}^{-3}\right]$ \\
\hline$S_{A c^{-}}$ & Concentração de íon acetato, $[\mathrm{M}] \cdot\left[\mathrm{L}^{-3}\right]$ \\
\hline$S_{\mathrm{Pr}^{-}}$ & Concentração de íon propionato, $[\mathrm{M}] .\left[\mathrm{L}^{-3}\right]$ \\
\hline$S_{B u^{-}}$ & Concentração de íon butirato, $[\mathrm{M}] .\left[\mathrm{L}^{-3}\right]$ \\
\hline$S_{V a^{-}}$ & Concentração de íon valerato, $[\mathrm{M}] .\left[\mathrm{L}^{-3}\right]$ \\
\hline$S_{O H^{-}}$ & Concentração de íon hidróxido, $[\mathrm{M}] \cdot\left[\mathrm{L}^{-3}\right]$ \\
\hline $\mathrm{S}_{\mathrm{CO}_{2}}$ & concentração de gás carbônico, $[\mathrm{M}] \cdot\left[\mathrm{L}^{-3}\right]$ \\
\hline$S_{N H 3}$ & concentração de amônia, [mol N].[L-3 $]$ \\
\hline$S_{f a}$ & concentração de ácidos graxos voláteis, $[\mathrm{M}] .\left[\mathrm{L}^{-3}\right]$ \\
\hline$S_{I C}$ & concentração de carbono inorgânico, $[\mathrm{mol}] \cdot\left[\mathrm{L}^{-3}\right]$ \\
\hline$S_{I N}$ & concentração de nitrogênio inorgânico, $[\mathrm{mol}] .\left[\mathrm{L}^{-3}\right]$ \\
\hline $\mathrm{Xc}$ & concentração de material particulado, $[\mathrm{M}] \cdot\left[\mathrm{L}^{-3}\right]$ \\
\hline Xch & concentração de carboidratos na forma particulada, $[\mathrm{M}] \cdot\left[\mathrm{L}^{-3}\right]$ \\
\hline Xpr & concentração de proteínas na forma particulada, $[\mathrm{M}] \cdot\left[\mathrm{L}^{-3}\right]$ \\
\hline Xli & concentração de lipídeos na forma particulada, $[\mathrm{M}] \cdot\left[\mathrm{L}^{-3}\right]$ \\
\hline
\end{tabular}




$\begin{array}{ll}\text { Xsu } & \text { concentração de decompositores de monossacarídeos, }[\mathrm{M}] \cdot\left[\mathrm{L}^{-3}\right] \\ \text { Xaa } & \text { concentração de decompositores de aminoácidos, }[\mathrm{M}] \cdot\left[\mathrm{L}^{-3}\right] \\ \text { Xfa } & \text { concentração de decompositores de ácidos graxos de cadeia longa, }[\mathrm{M}] .\left[\mathrm{L}^{-3}\right] \\ \text { Xc4 } & \text { concentração de decompositores de valerato e butirato, }[\mathrm{M}] \cdot\left[\mathrm{L}^{-3}\right] \\ \text { Xpro } & \text { concentração de decompositores de propionato, }[\mathrm{M}] \cdot\left[\mathrm{L}^{-3}\right] \\ \text { Xac } & \text { concentração de decompositores de acetato, }[\mathrm{M}] \cdot\left[\mathrm{L}^{-3}\right] \\ \text { Xh2 } & \text { concentração de decompositores de hidrogênio, }[\mathrm{M}] \cdot\left[\mathrm{L}^{-3}\right] \\ \text { Xi } & \text { concentração de inertes na forma particulada, }[\mathrm{M}] \cdot\left[\mathrm{L}^{-3}\right]\end{array}$




\section{RESUMO}

CARVALHO, K. Q. (2006). Resposta dinâmica de reator UASB em escala piloto submetido a cargas orgânicas e hidráulicas cíclicas: modelos matemáticos e resultados experimentais. Tese (Doutorado) - Escola de Engenharia de São Carlos, Universidade de São Paulo, São Carlos, 2006.

Poucos estudos são reportados na literatura sobre o comportamento dinâmico do reator UASB submetido a variações cíclicas diárias, de cargas orgânicas e hidráulicas, em períodos curtos de duração - iguais ou menores que $24 \mathrm{~h}$, com os quais verifica-se queda na eficiência do reator, causada pela provável flotação dos grânulos, problemas com geração de odor e alta concentração de sólidos suspensos no efluente. Para melhor compreender a resposta dinâmica desses reatores submetidos a essas variações, foi desenvolvido o modelo MMS baseado no modelo hidrodinâmico de mistura completa em reatores em série, modelo cinético de $1^{\text {a }}$ ordem para consumo de substrato e para crescimento da biomassa e equacionamentos empíricos reportados na literatura. Esse modelo indicou a capacidade do reator de amortecer as variações impostas e a influência da cinética na eficiência de remoção da matéria orgânica. Para calibrar e validar o MMS, foi avaliado o desempenho de um reator UASB $(160 \mathrm{~L})$ no tratamento de esgoto sanitário municipal da cidade de São Carlos. Durante o período de operação, o reator foi submetido a variações senoidais cíclicas, de cargas orgânica e hidráulica, em valores inferiores e superiores a $40 \%$ e $60 \%$ da vazão afluente de 16,0 L.h ${ }^{-1}$. A produção média de gás metano e a eficiência média de remoção de DQO alcançadas pelo reator foram de aproximadamente: $1,83 \mathrm{~L} \cdot \mathrm{h}^{-1}$ e $61 \%$ para vazão afluente de $16 \mathrm{~L} \cdot \mathrm{h}^{-1}$, TDH de $10 \mathrm{~h} \mathrm{e}$ velocidade ascensional de $0,23 \mathrm{~m} \cdot \mathrm{h}^{-1} ; 2,24 \mathrm{~L}^{-\mathrm{h}^{-1}}$ e $48 \%$ para variação cíclica de $40 \%$ e 2,97 L.h ${ }^{-1}$ e $40 \%$ para variação cíclica de $60 \%$. O MMS indicou faixa de valores para a DQO efluente com diferença em relação aos resultados observados experimentalmente - de $37 \%$ para vazão afluente constante de $16{\mathrm{~L} . \mathrm{h}^{-1}}^{-1}$ e $59 \%$ e $56 \%$ para variações senoidais cíclicas de $40 \%$ e $60 \%$ da vazão afluente, respectivamente devido à limitação do modelo em considerar o arraste de sólidos no efluente que ocorreu ao longo de toda a operação do reator e mais acentuadamente quando foram aplicadas variações da vazão afluente. O modelo ADM1 proposto por Batstone et al. (2002a,b) apresentou menor similaridade com os resultados observados experimentalmente por não contemplar a variação horária e diária de alguns parâmetros de entrada, mas apenas a média aritmética dos valores.

Palavras Chave: comportamento dinâmico, variação cíclica da vazão, carga orgânica, carga hidráulica, modelação matemática, UASB. 


\section{ABSTRACT}

CARVALHO, K. Q. (2006). Dynamic response of a UASB reactor submitted to organic and hydraulic cyclical loads: mathematical models and experimental results.

Ph.D. Thesis - Escola de Engenharia de São Carlos - Universidade de São Paulo, São Carlos, 2006.

There are no extensive reports on the dynamic behaviour of UASB reactor submitted to cyclical daily variations of organic and hydraulic loads of short periods of time equal to or shorter than 24 hours - that can damage the reactor efficiency due to probable granule flotation, odor generation and high concentration of suspended solids in the effluent. Aiming to understand the dynamic response of these reactors when submitted to these variations, it was developed the MMS model based on the $\mathrm{N}$-continuous flow stirred tank reactors (CSTR) in series model, first order kinetics model for substrate consumption and biomass growth and empirical equations reported in the literature. The model indicated the reactor capacity on dampening the imposed flow rate variations and the influence of the kinetics in the organic matter removal efficiency. It was evaluated the response of a UASB in bench scale $(160 \mathrm{~L})$ treating sanitary sewage of São Carlos city in order to calibrate and validate the MMS. During the operation, the reactor was submitted to cyclical sinusoidal variations of organic and hydraulic loads in lesser and higher values of $40 \%$ and $60 \%$ of the influent flow rate of $16 \mathrm{~L} \cdot \mathrm{h}^{-1}$. The reactor achieved mean methane production and mean COD removal efficiency of: $1,83 \mathrm{~L}^{-1} \mathrm{~h}^{-1}$ and $61 \%$ to influent flow rate of $16{\mathrm{~L} . \mathrm{h}^{-1}}^{-}$HRT of $10 \mathrm{~h}$ and upflow velocity of $0,23 \mathrm{~m} \cdot \mathrm{h}^{-1} ; 2,24 \mathrm{~L} \cdot \mathrm{h}^{-1}$ and $48 \%$ to sinusoidal variation of $40 \% ; 2,97 \mathrm{~L} . \mathrm{h}^{-1}$ and $40 \%$ to sinusoidal variation of $60 \%$. The MMS model results indicated a range of effluent COD values with a difference of $37 \%$ to influent flow rate of $16{\mathrm{~L} . \mathrm{h}^{-1}}^{-1} 59 \%$ and $56 \%$ to sinusoidal variations of $40 \%$ and $60 \%$, respectively, in comparison with the experimental observed data. This probably occurred due to the model limitation in considering and predicting the solids washout in the effluent that was verified during all the operation, and also more significant when the sinusoidal variations were applied. The ADM1 reported by Batstone et al. (2002a,b) presented lesser similarity with the experimental observed results due to the fact that it does not consider hourly and daily variations of some input parameters, but only the arithmetical mean of the values.

Keywords: dynamic behavior, cyclical flow rate variation, organic load, hydraulic load, mathematical modeling, UASB. 


\section{INTRODUÇÃO}

De acordo com o Instituto Brasileiro de Geografia e Estatística (2002), o Brasil possui mais de 300 reatores anaeróbios operados em escala real tratando esgoto sanitário, principalmente no estado do Paraná. Em alguns casos, o tratamento anaeróbio de esgotos domésticos corresponde ao pré-tratamento biológico, seguido de algum polimento posterior para que os padrões de lançamento estabelecidos pela legislação ambiental vigente sejam alcançados. Apesar desse número de reatores em operação, a literatura é escassa de informações referentes ao comportamento de reatores UASB submetidos a variações cíclicas diárias de cargas orgânicas e hidráulicas comuns em pequenas instalações de tratamento.

Essas variações podem causar queda na eficiência do reator e conseqüentemente lançamento de efluentes com concentrações de poluentes superiores aos limites estabelecidos pela legislação ambiental vigente (PIRES et al., 2001). Com a aplicação das variações, a eficiência de remoção do reator pode ser afetada pela flotação dos grânulos, problemas com geração de odor e elevada concentração de sólidos suspensos no efluente.

Alguns estudos realizados com reator UASB mostraram sua capacidade em amortecer cargas hidráulicas e orgânicas às quais foi submetido após certo período de tempo (PAULA JR., 1992; OLIVA, 1997; BATISTA, 2000; AISSE et al., 2000; FLORENCIO et al., 2001; FRANCO et al., 2002a; FRANCO et al., 2002b; LEITÃO, 2004). Por outro lado, outros estudos indicaram que o comportamento hidrodinâmico do reator permaneceu desconhecido (BATISTA, 2000). Portanto é conveniente avaliar eventuais flutuações de comportamento resultantes de variações de cargas hidráulica e orgânica no projeto de reatores UASB.

Para melhor compreender os eventuais amortecimentos e atrasos nas respostas desses reatores quando submetidos a essas variações, Carvalho e Pires 
(2002) desenvolveram um modelo matemático simplificado (MMS) baseado no modelo hidrodinâmico de mistura completa em reatores em série, modelo cinético de primeira ordem para consumo de substrato e para crescimento da biomassa e equacionamentos empíricos reportados por Paula Jr. (1992) e Batista (2000). Esse modelo, que correspondeu a um aprimoramento do modelo desenvolvido por Carvalho (2002), indicou a capacidade do reator de amortecer as variações impostas e a influência da cinética na eficiência de remoção da matéria orgânica.

Devido à necessidade de validar o modelo matemático simplificado (MMS), foi avaliado o desempenho de um reator UASB em escala piloto, com capacidade de 160 L, no tratamento de esgoto sanitário municipal da cidade de São Carlos. O reator UASB foi instalado no Laboratório de Tratamento de Resíduos (LTR) da Universidade de São Paulo (área I) em São Carlos (EESC/USP).

Durante o período de operação, o reator UASB foi submetido a variações cíclicas diárias de cargas orgânica e hidráulica em valores inferiores e superiores a $40 \%$ e $60 \%$. Os resultados experimentais obtidos com a operação desse reator foram aplicados como dados de entrada para validação do modelo MMS e para calibração do modelo ADM1 (Anaerobic Digestion Model $n_{o}$ 1) proposto por Batstone et al. (2002a,b). 


\section{OBJETIVOS}

O principal objetivo deste trabalho foi validar o modelo matemático simplificado (MMS) desenvolvido por Carvalho e Pires (2002). Esse modelo é considerado simplificado quando comparado a outros modelos de digestão anaeróbia reportados na literatura, como por exemplo Bolle et al. (1986) e Batstone et al. (2002a,b), por contemplar apenas os processos de conversão do substrato em biomassa ativa e a remoção da matéria orgânica.

Os principais objetivos específicos corresponderam a:

- avaliação do comportamento do reator UASB, em escala piloto, no tratamento de esgoto sanitário, quando submetido a variações cíclicas diárias de cargas hidráulicas e orgânicas;

- estudo do regime hidrodinâmico do fluido no reator UASB devido à influência da variação de vazão;

- aplicação dos resultados obtidos durante a operação do reator UASB como dados de entrada para calibração do modelo ADM1 e validação do modelo MMS;

- comparação dos resultados da validação do modelo MMS com aqueles obtidos com a calibração do modelo ADM1. 


\section{REVISÃO DE LITERATURA}

Esse capítulo aborda inicialmente o comportamento dinâmico de reatores UASB (Upflow Anaerobic Sludge Blanket) submetidos a variações de cargas de origem orgânica e hidráulica, devido a variações na vazão e na composição dos esgotos ao longo do dia. Na sequiência são ainda abordados os efeitos da duração e freqüência dos distúrbios aplicados.

Para finalizar, são ainda abordadas algumas aplicações de modelos matemáticos de processos de digestão anaeróbia e do modelo ADM1 (Anaerobic Digestion Model $n_{o}$ 1).

\subsection{REATORES UASB (UPFLOW ANAEROBIC SLUDGE BLANKET)}

O reator UASB foi inicialmente proposto para tratamento de efluentes industriais de elevada concentração em temperaturas mesofílicas (LETTINGA et al., 1980). Devido ao sucesso no tratamento desses efluentes, passou a ser aplicado no tratamento de esgotos domésticos no início da década de 80 em diversos países como Colômbia, Brasil, México, Cuba, dentre outros.

Os processos anaeróbios (com ênfase no reator UASB) apresentam algumas vantagens e desvantagens em relação aos processos aeróbios convencionais (Tabela 1). Deve-se ressaltar, entretanto que as desvantagens citadas dependem principalmente das características da água residuária e das condições operacionais do processo, podendo muitas vezes ser minimizadas. 
Tabela 1. Algumas vantagens e desvantagens dos processos anaeróbios (reator UASB) em relação aos processos aeróbios convencionais

\begin{tabular}{c|c}
\hline vantagens & Desvantagens \\
\hline simplicidade de construção e operação & geração de maus odores \\
baixa demanda de área & longo intervalo de tempo necessário \\
baixos custos de energia elétrica & para partida (sem inóculo) \\
baixa produção de lodo & necessidade de pós-tratamento para \\
boa desidratabilidade do lodo & atender a legislação vigente \\
reúso do lodo em novos reatores & baixa remoção de nutrientes e patógenos \\
eficiência de remoção da & \\
matéria orgânica (65\% a 75\% - DQO) & \\
\hline
\end{tabular}

Fonte: adaptado de Foresti (2002); Seghezzo (2004)

O comportamento dos reatores UASB no tratamento de esgotos sanitários tem sido amplamente avaliado em instalações de bancada, piloto e real (PAULA JR., 1992; OLIVA, 1997; PASSIG et al., 2000; LEITÃO, 2004).

A Tabela 2 apresenta algumas aplicações de reatores UASB no tratamento de esgotos sanitários em diferentes escalas.

Os resultados reportados indicaram comportamento satisfatório desses reatores quando aplicados no tratamento de esgotos sanitários em regiões com temperatura superior a $20^{\circ} \mathrm{C}$, alcançando eficiências de remoção de DQO (Demanda Química de Oxigênio) variável na faixa de $65 \%$ a $80 \%$ para taxas de carregamento orgânicas inferiores a $3 \mathrm{kgDQO} \cdot \mathrm{m}^{-3} \cdot \mathrm{d}^{-1}$ e TDH (Tempo de detenção hidráulica) variando de $6 \mathrm{~h}$ a $10 \mathrm{~h}$ (PASSIG et al., 2000; FLORENCIO et al., 2001; TORRES e FORESTI, 2001; LEITÃO, 2004, LEITÃO et al., 2005). 
Tabela 2. Aplicações de reatores UASB no tratamento de esgotos sanitários

\begin{tabular}{|c|c|c|c|c|c|c|}
\hline \multirow{2}{*}{$\begin{array}{c}\mathbf{V} \\
\left(\mathrm{m}^{3}\right)\end{array}$} & \multirow{2}{*}{$\begin{array}{l}\mathbf{T} \\
{ }^{\circ} \mathrm{C}\end{array}$} & \multirow{2}{*}{$\begin{array}{c}\text { DQO } \\
\left(\mathrm{mg} . \mathrm{L}^{-1}\right)\end{array}$} & \multirow{2}{*}{$\begin{array}{r}\text { TDH } \\
\text { (h) } \\
\end{array}$} & \multicolumn{2}{|c|}{$\begin{array}{l}\text { Eficiência de } \\
\text { remoção }\end{array}$} & \multirow[t]{2}{*}{ Referências } \\
\hline & & & & $\begin{array}{c}\text { DQO } \\
(\%)\end{array}$ & $\begin{array}{r}\text { SST } \\
(\%) \\
\end{array}$ & \\
\hline 0,12 & $18-20$ & $\begin{array}{c}248-581 \\
190-\end{array}$ & 12 & 72 & - & $\begin{array}{l}\text { Lettinga et al. }(1983) \\
\text { de Man et al. }(1988)^{1} \text { apud }\end{array}$ \\
\hline 0,12 & $12-20$ & 1180 & $7-8$ & $30-75$ & - & Leitão (2004) \\
\hline 0,12 & $19-28$ & 627 & 4 & 74 & 72 & $\begin{array}{l}\text { Barbosa e Sant' Anna Jr. } \\
\text { (1989) }\end{array}$ \\
\hline 18 & $>20$ & 639 & 8 & $71-83$ & $71-85$ & Oliva (1997) \\
\hline 2,8 & $18-20$ & $297-855$ & 12 & $55-75$ & 75 & Passig et al. (2000) \\
\hline 0,145 & 21 & - & 6 & 71 & 62 & Torres (2000) \\
\hline 810 & 30 & 563 & 9,7 & 67 & 61 & Florêncio (2001) \\
\hline 0,12 & 25 & 816 & 6 & 57 & - & Leitão $(2004)^{*}$ \\
\hline 0,501 & 23 & 214 & 6 & $65-70$ & - & Seghezzo (2004)* \\
\hline 18,8 & 23 & 522 & 6 & 56 & - & Passig (2005) \\
\hline
\end{tabular}

*Os autores operaram reatores UASB com configurações diferentes daquela representada pela Figura 1 (UASB convencional)

$\mathrm{V}$ : volume do reator; T: temperatura de operação; TDH: tempo de detenção hidráulica.

$\mathrm{Na}$ literatura não existem relatos de falência do processo devido ao desbalanceamento entre o consumo e a produção de ácidos voláteis em reatores anaeróbios tratando esgotos domésticos (FORESTI, 2002). Para esse tipo de esgoto, com baixas concentrações, a produção de ácidos graxos voláteis não é significativa e assim suas concentrações são na maioria das vezes inferiores aos limites de inibição, permitindo que a metanogênese ocorra.

As sobrecargas hidráulicas ou projeto e operação inadequados dos reatores têm sido comumente relacionados à instabilidade dos reatores anaeróbios tratando esgotos domésticos. A instabilidade do processo pode ser evitada por exemplo, se valores adequados de TDH forem adotados.

\footnotetext{
${ }^{1}$ de Man, A.W.A.; van der Last, A.R.M.; Lettinga, G. (1988). The use of EGSB and UASB anaerobic systems or low strength soluble and complex wastewaters at temperatures ranging from 8 to $30^{\circ} \mathrm{C}$. IN: Proceedings of the $5^{\text {th }}$ International Symposium on Anaerobic Digestion, Hall, E.R.; and Hobson, P.N., eds., Bologna, Italy, 197-208.
} 
Mesmo com as vantagens reconhecidas da aplicação do processo anaeróbio, dúvidas sobre a estabilidade do reator e a variabilidade da qualidade do efluente ainda existem.

Em relação à estabilidade operacional do reator existe uma série de artigos que reportam os resultados do tratamento anaeróbio de esgoto doméstico (SEGHEZZO et al., 2002; HALALSHEH, 2002; LEW et al., 2004 e LEITÃO, 2004). Contudo cada artigo se refere a uma faixa restrita de condições operacionais, o que dificulta a comparação de diferentes investigações. Além disso, os dados disponíveis são limitados para reatores UASB tratando esgoto em condições extremas, como por exemplo, com baixas concentrações de matéria orgânica no afluente ou baixos tempos de detenção hidráulica.

Dentro desse contexto, há escassez de estudos na literatura sobre variações cíclicas diárias de cargas orgânicas e hidráulicas de curtos períodos de duração (iguais ou menores do que 24 h). Essas variações, típicas de esgotos domésticos, podem causar flotação dos grânulos do reator, problemas com geração de odor e elevada concentração de sólidos suspensos no efluente. Esses efeitos, por sua vez, podem promover queda na eficiência de remoção de alguns parâmetros de controle de reatores em estações de tratamento e conseqüentemente lançamento de efluentes com concentrações de poluentes superiores aos limites estabelecidos pela legislação ambiental vigente (PIRES et al., 2001).

Embora acarretando em maiores custos com instalação, operação ou ambos, alguns autores (MITRA et al., 1998 e BEHLING et al., 1997) estudaram mecanismos para amortecimento das variações de cargas hidráulicas e orgânicas.

Mitra et al. (1998) desenvolveram estudo com uso de trocadores iônicos compostos (TIC) para melhorar a eficiência de 3 reatores anaeróbios (de mesmo volume) submetidos a cargas de choque orgânicas (em termos de DBO). O íon polimérico utilizado, com textura e morfologia compatíveis ao meio biológico de elevada concentração de sólidos, é composto em massa por $80 \%$ de micro partículas esféricas fixadas em $20 \%$ de fibra de politetrafluoretano (Teflon). Esse íon é capaz de liberar lentamente os íons de hidrogênio capturados, estabilizando o pH e restabelecendo as condições de estabilidade dos reatores, sem necessidade de regeneração ou de cuidados especiais por parte dos operadores dos sistemas. 
Os autores submeteram três reatores tipo mistura completa a cargas de choque de DBO cinco vezes maiores que a carga normal aplicada. Os reatores foram mantidos à temperatura aproximada de $35 \pm 0,1^{\circ} \mathrm{C}$ e alimentados com $50 \mathrm{~mL}$ de uma mistura de glicose com concentração de $10000 \mathrm{mg} . \mathrm{L}^{-1}$ e alcalinidade de $1800 \mathrm{mg} . \mathrm{L}^{-1}$.

O primeiro reator (1) não continha TIC, enquanto os demais reatores (2) e (3) continham $77 \mathrm{~cm}^{2}$ e $155 \mathrm{~cm}^{2}$, respectivamente. Paralelamente, um reator de controle (RC) que não estava submetido às cargas de choque de DBO foi operado para verificar e comparar produção de metano, $\mathrm{pH}$, concentração de carbono orgânico total e alcalinidade com os demais reatores. O reator (RC) não demonstrou instabilidade operacional apresentada pelos demais reatores. Os reatores (1), (2) e (3) apresentaram diminuição dos valores de $\mathrm{pH}$, sendo que o reator (3) demonstrou lenta recuperação de seu estado estacionário após certo tempo de operação. Os autores observaram ainda repentino aumento da produção de metano com aumento da concentração do substrato nos reatores, inibição da atividade metanogênica no reator (1) e aumento dessa atividade no reator (3).

Behling et al. (1997) avaliaram o comportamento de um reator UASB em escala piloto com volume de $55 \mathrm{~L}$, alimentado com esgoto municipal doméstico ao longo de 200 dias. O reator, inoculado com lodo pré-granulado de cervejaria local, foi operado com tempo de detenção hidráulica de 7,6 h e vazão de alimentação constante de 7,2 L.h. ${ }^{-1}$.

Como o esgoto era bombeado para o reator, notou-se variação da taxa de carregamento orgânica entre 0,5 a 3,9 $\mathrm{kgDQO} \cdot \mathrm{m}^{-3} \cdot \mathrm{d}^{-1}$, a qual se estabilizou após o $18^{\circ}$ dia de operação com introdução de um tanque de equalização, responsável pelo recebimento e encaminhamento do esgoto afluente ao reator. Assim, a taxa de carregamento passou a ser constante e igual a $1,21 \mathrm{kgDQO} \cdot \mathrm{m}^{-3} \cdot \mathrm{d}^{-1}$. Os autores observaram a capacidade do tanque de equalização em amortecer as variações, por meio de determinação dos parâmetros DQO, sólidos suspensos, alcalinidade, produção de metano e ácidos voláteis. A introdução do tanque de equalização promoveu aumento da produção de biogás e decréscimo gradativo na DQO efluente, as quais alcançaram condições de equilíbrio a $28 \mathrm{~L}^{\mathrm{d}} \mathrm{d}^{-1}$ e $56 \mathrm{mg} . \mathrm{d}^{-1}$, respectivamente. 


\subsection{COMPORTAMENTO DE REATORES ANAERÓBIOS SUBMETIDOS A CARGAS DE CHOQUE}

Diversos pesquisadores estudaram os efeitos das variações operacionais e ambientais no comportamento de sistemas anaeróbios visando aprimorar o conhecimento sobre a estabilidade e a confiabilidade desses sistemas no tratamento de águas residuárias.

O comportamento dinâmico dos reatores anaeróbios submetidos a essas variações depende diretamente do tipo, da magnitude, da duração e da freqüência das variações impostas.

Variações de um ou mais parâmetros tais como vazão afluente, tipo e concentração de esgoto, tempo de retenção celular, disponibilidade de nutrientes, temperatura e pH são comuns em estações de tratamento de esgotos. Alguns desses parâmetros podem ser previstos e/ou controlados, auxiliando no projeto dos reatores.

Os sistemas de tratamento de esgotos podem ser expostos a diversas variações, tais como: variações na composição dos esgotos ao longo do dia devido à natureza cíclica das atividades humanas (METCALF e EDDY, 1991; HANAI, 1997; OLIVA, 1997); variações de vazão ao longo do ano devido à presença de população flutuante em períodos de férias em áreas turísticas; sobrecargas hidráulicas e orgânicas resultantes de procedimentos operacionais adotados nas estações de tratamento de esgotos (BORJA e BANKS, 1995; OLIVA, 1997; BRITO E MELO, 1999).

Os reatores anaeróbios podem apresentar como resposta às variações impostas: queda na eficiência de remoção de alguns parâmetros de controle, acúmulo de ácidos voláteis, queda no pH e consumo de alcalinidade, alteração na composição e produção de biogás e arraste de lodo. 


\subsubsection{VARIAÇÕES NA VAZÃO E COMPOSIÇÃO DOS ESGOTOS AO LONGO DO DIA}

O esgoto doméstico geralmente apresenta variações em sua composição devido à influência de fatores como número de habitantes, usos e costumes da população, clima, topografia, contribuições comerciais e industriais e contribuições clandestinas de águas pluviais.

Hanai (1997) e Oliva (1997) verificaram contribuições simultâneas de águas residuárias e de águas pluviais (clandestinas) nas cidades de Araraquara e de São Carlos, respectivamente, que causaram choques hidráulicos tanto no sistema coletor como nas unidades de tratamento de esgotos, prejudicando os processos biológicos devido ao aumento da DQO afluente, principalmente em dias chuvosos. Os mesmos autores observaram que as contribuições de esgoto industrial promoveram variação dos parâmetros DQO, pH e temperatura, sendo que Hanai (1997) verificou picos de máximo iguais a $3076 \mathrm{mg} . \mathrm{L}^{-1}, 11$ e $35^{\circ} \mathrm{C}$, respectivamente.

Orhon et al. (1997) notaram concentrações elevadas de detergentes (160 mg. $\mathrm{L}^{-1}$ a $\left.760 \mathrm{mg} . \mathrm{L}^{-1}\right)$ e de cloro $\left(1000 \mathrm{mg} . \mathrm{L}^{-1}\right)$ em áreas que recebiam contribuições industriais de um complexo de curtumes na cidade de Istambul (Turquia).

Em relação aos usos e costumes da população, Oliva (1997) constatou variações nas concentrações do esgoto doméstico (em termos de DQO) de 117\% ao longo das horas do dia e de $103 \%$ ao longo dos dias da semana.

Campos e von Sperling (1996) ao realizarem estudos de caracterização de águas residuárias da cidade de Belo Horizonte/MG observaram variações de vazão mais elevadas do que àquelas usadas para o projeto de estações de tratamento, maior duração das variações em áreas de classe mais alta e variações na composição das águas residuárias em função da hora do dia e do dia da semana, dependendo do salário familiar, padrão de vida e tipo de ocupação do solo.

Orhon et al. (1997) verificaram concentração média de matéria orgânica de aproximadamente $1000 \mathrm{mgDQO} . \mathrm{L}^{-1} \mathrm{em}$ área residencial menos favorecida da região metropolitana de Istambul, que sofre com falta de abastecimento de água. 


\subsubsection{EFEITOS DAS VARIAÇÕES DAS CARGAS ORGÂNICAS E HIDRÁULICAS}

Um delicado balanço existe entre os processos primários (hidrólise e acidogênese) e a conversão de produtos ácidos em metano e dióxido de carbono pelas bactérias acetogênicas e arquéias metanogênicas na digestão anaeróbia.

De acordo com diversas pesquisas, variações na vazão e na concentração do afluente podem afetar a eficiência de reatores UASB. O efeito das variações em cargas hidráulicas e orgânicas depende do tempo de detenção hidráulica, do tempo de retenção celular, da intensidade e duração das variações, das propriedades do lodo e do projeto de reatores, principalmente da configuração dos separadores de fases.

$\mathrm{O}$ acúmulo de ácidos voláteis (AGV) pode ser uma das respostas do reator quando submetido a variações nas taxas de carregamento hidráulica e orgânica. A pressão parcial de hidrogênio representa importante papel no controle das proporções de vários produtos intermediários das reações anaeróbias. Em condições de sobrecargas ou de variações, pode haver desequilíbrio na razão entre microrganismos que produzem e que consomem AGV, acarretando produção de quantidades significativas de dióxido de carbono e de hidrogênio no biogás. Devido as menores taxas de crescimento dos microrganismos metanogênicos, em relação aos acetogênicos, estes não conseguem consumir rapidamente o gás hidrogênio produzido pelos microrganismos hidrogenotróficos, que pode acarretar acúmulo de propionato, butirato e lactato. Outro tipo de efeito durante situações de estresse é a mudança na composição e na taxa de produção do biogás (CHUA et al., 1997).

Borja e Banks (1995) avaliaram o efeito de cargas de choque hidráulicas e orgânicas na eficiência de um reator anaeróbio de leito fluidificado. O reator, operado com TDH de $8 \mathrm{~h}$, foi alimentado com água residuária de indústria de sorvete com TCO de 15,6 kgDQO. $\mathrm{m}^{-3} \cdot \mathrm{d}^{-1}$. A vazão afluente foi aumentada em $100 \%$ e $150 \%$ por períodos de seis e doze horas, acarretando em queda do $\mathrm{pH}$ de 7,1 para 6,6 e da alcalinidade do sistema, com aumento da concentração de AGV e de DQO no efluente durante a aplicação do choque. A produção de biogás aumentou, porém com decréscimo do conteúdo de metano devido à inibição da metanogênese e diminuição da solubilidade do $\mathrm{CO}_{2}$ em baixos valores de $\mathrm{pH}$. Para as cargas de choque 
orgânicas, os autores aumentaram a DQO afluente em 100\% e $150 \%$ por períodos de seis e doze horas que causaram efeitos similares àqueles verificados com variações de cargas hidráulicas. $\mathrm{O}$ pH do sistema permaneceu estável devido a maior capacidade de tamponamento da água residuária de maior concentração. $\mathrm{O}$ choque orgânico mais severo aplicado ao sistema (150\% da DQO afluente) por doze horas, causou aumento da DQO efluente em $180 \%$, porém o sistema apresentou capacidade de recuperação após $6 \mathrm{~h}$ a 11 h do término do choque.

Chua et al. (1997) avaliaram a resposta de um reator anaeróbio de filme fixo (RAFF) alimentado com água residuária sintética, simulando água residuária de laticínio com $3000 \mathrm{mgDQO} . \mathrm{L}^{-1}$ e submetido a cargas de choque hidráulicas. O reator, composto por coluna de vidro recheada com esferas cerâmicas, com volume de $3 \mathrm{~L}$, foi mantido à temperatura de aproximadamente $30^{\circ} \mathrm{C}$. Após o estado de equilíbrio dinâmico aparente ter sido alcançado com tempo de detenção hidráulica de $5 \mathrm{~d}$, o reator foi submetido a sobrecargas hidráulicas com redução do TDH para 1,25 d, $1,0 \mathrm{~d}$ e $0,5 \mathrm{~d}$, com TCO constante e DQO reduzida à metade do valor inicial.

Os autores concluíram que, para sobrecargas hidráulicas de até 5 vezes (TDH de 1 d), houve redução na eficiência de remoção de DQO de $98 \%$ para $88 \%$ e acúmulo dos ácidos etanóico $\left(24 \mathrm{mg} . \mathrm{L}^{-1}\right)$ e propiônico $\left(70 \mathrm{mg} \cdot \mathrm{L}^{-1}\right)$. Com sobrecarga hidráulica 10 vezes superior (TDH de 0,5 d), a eficiência de remoção de DQO diminuiu para $70 \%$, ocorrendo acidificação $(\mathrm{pH}$ de 5,5) do reator com elevadas concentrações dos ácidos etanóico $\left(250 \mathrm{mg} . \mathrm{L}^{-1}\right)$ e propiônico $\left(312 \mathrm{mg} . \mathrm{L}^{-1}\right)$ e redução na produção de biogás de $0,5 \mathrm{~L} \cdot \mathrm{d}^{-1}$ para $0,25 \mathrm{~L} \cdot \mathrm{d}^{-1}$. Ao longo de toda a operação do reator, a concentração de sólidos suspensos voláteis no efluente manteve-se na faixa de $40 \mathrm{mg} . \mathrm{L}^{-1}$ a $70 \mathrm{mg} . \mathrm{L}^{-1}$. A recuperação e a estabilidade do sistema foram possíveis após 3 dias do restabelecimento das condições iniciais (TDH de 5 d) de operação e atribuídas ao emprego de biofilme imobilizado.

Oliva (1997) operou reator UASB protótipo $\left(18 \mathrm{~m}^{3}\right)$ tratando esgoto sanitário proveniente da rede coletora da cidade de São Carlos - SP com o objetivo de avaliar os efeitos de sobrecargas hidráulicas no tratamento de esgotos sanitários e a continuidade dos possíveis efeitos dessas sobrecargas por meio de simulação de variação de vazão. Após ter alcançado o estado de equilíbrio dinâmico aparente, o reator foi operado com TDH de $8 \mathrm{~h}$, vazão média afluente de $2,25 \mathrm{~m}^{3} \cdot \mathrm{h}^{-1}$, taxa de 
aplicação volumétrica média de $2,7 \mathrm{kgDQO} . \mathrm{m}^{-3}$ e taxa de carregamento orgânica média de $48 \mathrm{kgDQO} . \mathrm{d}^{-1}$. Nessas condições operacionais, o reator apresentou eficiências médias de remoção de $71 \%$ a $83 \%$ para DQO bruta e $80 \%$ a $91 \%$ para DQO filtrada.

A autora realizou ensaios de resposta dinâmica com aplicação de sobrecarga hidráulica de cinqüenta por cento $\left(3,4 \mathrm{~m}^{3} \cdot \mathrm{h}^{-1}\right)$ em relação à vazão normal de operação $\left(2,25 \mathrm{~m}^{3} \cdot \mathrm{h}^{-1}\right)$, verificando que esse pulso de vazão não causou resposta significativa e imediata no desempenho do processo. A autora observou ainda que, logo após a aplicação do pulso não ocorreram picos sistemáticos de vazão pela manhã; porém picos superiores de DQO afluente no período da tarde em relação aos verificados no período da manhã. As eficiências médias obtidas para remoção de DQO variaram de $76 \%$ a $86 \%$ às $9 \mathrm{~h}$, de $74 \%$ a $80 \%$ às $12 \mathrm{~h}$, de $62 \%$ a $75 \%$ às $17 \mathrm{~h}$ e de $61 \%$ a $75 \%$ às $20 \mathrm{~h}$.

Também foram realizados ensaios de resposta dinâmica com aplicação de sobrecargas hidráulicas de cem por cento $\left(4,5 \mathrm{~m}^{3} \cdot \mathrm{h}^{-1}\right)$, que provocou aumento de DQO afluente inicial durante os primeiros 15 minutos após sua aplicação, acarretando em arraste de sólidos no efluente do reator. Esse aumento continuou até que o pulso fosse finalizado. A confiabilidade do sistema de tratamento foi destacada por meio das eficiências médias obtidas para remoção de DQO variando de $68 \%$ a $83 \%$ às 9 h e de $61 \%$ a $76 \%$ às $13 \mathrm{~h}$, que indicaram sua capacidade de amortecimento às sobrecargas impostas.

Castillo et al. (1997) estudaram o comportamento de um reator UASB submetido a variações de TDH de $1,5 \mathrm{~h}, 3 \mathrm{~h}, 6 \mathrm{~h}$ e $7,5 \mathrm{~h}$ no verão $\left(\sim 20^{\circ} \mathrm{C}\right)$ e no inverno $\left(\sim 13^{\circ} \mathrm{C}\right)$. O reator em escala piloto (volume de $750 \mathrm{~L}$ ) foi alimentado com esgoto doméstico com DQO afluente de $600 \mathrm{mg} . \mathrm{L}^{-1}$.

Os autores observaram que as eficiências de remoção de DQO total, DQO solúvel e DQO em suspensão aumentaram com o aumento do TDH para ambas as estações do ano. Além disso foi possível verificar que, quando o reator foi operado no inverno, as eficiências de remoção de matéria orgânica (DQO total) foram inferiores de $5 \%$ a $15 \%$ àquelas observadas para o período de verão. Após cada variação de TCO (devido aos aumentos do TDH), o reator demonstrou período de instabilidade antes de alcançar o estado de equilíbrio dinâmico aparente. 
Kalyuzhnyi et al. (1996) investigaram o desempenho de um reator UASB em escala de laboratório (2,7 L), alimentado com substrato sintético à base de glicose e mantido à temperatura de $35^{\circ} \mathrm{C}$. $\mathrm{O}$ reator foi continuamente alimentado com taxa de carregamento orgânico (TCO) variando de 3,4 gDQO.L ${ }^{-1} \cdot \mathrm{d}^{-1}$ a 44,9 gDQO.L $\mathrm{L}^{-1} \cdot \mathrm{d}^{-1}$, tempo de detenção hidráulica (TDH) variando de 4,0 h a 22,5 h e DQO afluente variando de 3,21 g.L. $\mathrm{L}^{-1}$ a 7,5 g.L $\mathrm{L}^{-1}$. Quando o reator alcançou eficiência de $98 \%$ na remoção da DQO afluente (estado quase estacionário), a TCO foi lentamente aumentada de 3,4 gDQO.L $\mathrm{L}^{-1} \cdot \mathrm{d}^{-1}$ para 44,9 gDQO. $\mathrm{L}^{-1} \cdot \mathrm{d}^{-1}$ com acréscimo da vazão ou da DQO afluente. O estudo mostrou que o estado quase estacionário pode ser alcançado dentro de uma ampla faixa de mudanças de TCO. Aparecimento de bolhas de gás na zona da manta de lodo, flotação parcial do lodo, destruição dos grânulos, acumulação de AGV e eficiência de remoção de DQO de aproximadamente $65 \%$ foram observados quando sobrecargas foram impostas ao reator. $\mathrm{O}$ reator alcançou eficiência de remoção de DQO de 96\% quando foi aplicado TDH variando de $12 \mathrm{~h}$ a $15 \mathrm{~h}$ e TCO igual a 21 gDQO. $\mathrm{L}^{-1} \cdot \mathrm{d}^{-1}$. Para TCO igual a 44,9 gDQO.L $\mathrm{L}^{-1} \cdot \mathrm{d}^{-1}$ foi necessário aplicar TDH de $30 \mathrm{~h}$ para que o reator alcançasse eficiência de remoção de DQO igual a $97 \%$.

De acordo com os autores, a biomassa rapidamente se adaptou aos aumentos sucessivos da TCO, o que promoveu elevada eficiência da conversão do substrato. Com aumento lento da TCO, houve aumento da concentração de biomassa na faixa de 28 gSSV.L ${ }^{-1}$ a 38 gSSV.L ${ }^{-1}$ no volume total do reator e na faixa de 60 gSSV.L ${ }^{-1}$ a 70 gSSV.L ${ }^{-1}$ na zona de manto de lodo. Quando foi aplicada TCO de 44,9 gDQO.L ${ }^{-1} \cdot \mathrm{d}^{-1}$ e TDH de 4 h, o reator apresentou eficiência de remoção de DQO de $97 \%$ e taxa de produção de metano de $14,7 \mathrm{~L} \cdot \mathrm{L}^{-1} \cdot \mathrm{d}^{-1}$.

Pires et al. (2001), analisando o trabalho realizado por Batista (2000), avaliaram o comportamento dinâmico de um reator UASB $(10,5 \mathrm{~L})$, em escala de laboratório, submetido a variações cíclicas diárias de cargas orgânicas e hidráulicas de esgoto sintético simulando esgoto real. O reator foi inoculado com lodo anaeróbio proveniente de reator UASB em escala real tratando esgoto doméstico e mantido à temperatura de aproximadamente $30 \pm 1^{\circ} \mathrm{C}$. Para avaliar a eficiência de remoção de DQO durante intervalos de tempo de 24 h e 48 h e verificar a influência da variação 
da vazão afluente, o reator foi submetido à variação senoidal cíclica diária de valores inferiores e superiores a 30\%, $45 \%$ e $60 \%$ da vazão média afluente de 1,31 L.h ${ }^{-1}$.

$\mathrm{O}$ reator alcançou o estado de equilíbrio dinâmico aparente após $12 \mathrm{~h}$ da aplicação das variações senoidais cíclicas de $30 \%$ e $45 \%$ que resultaram em eficiências de remoção da DQO afluente de $500 \mathrm{mg} . \mathrm{L}^{-1}$ iguais a $82 \%$ e $84 \%$, respectivamente. O tempo de resposta (estabilização) do reator à variação de $60 \%$ foi alcançado após $20 \mathrm{~h}$ de sua aplicação com aproximadamente $79 \%$ de remoção da DQO afluente. Como os autores verificaram que a estabilidade do reator em relação à eficiência de remoção de DQO não foi influenciada pela aplicação da variação horária da vazão afluente, foi necessário aumentar a concentração da matéria orgânica para $1000 \mathrm{mgDQO} . \mathrm{L}^{-1}$ e a variação da vazão média afluente para $60 \%$. Com aplicação dessas condições operacionais, o reator apresentou menor eficiência na remoção de DQO bruta $(65 \%)$ e resposta similar às variações de vazão.

Os autores concluíram ainda que, as sobrecargas hidráulicas promoveram diminuição da eficiência de remoção de DQO e prejudicaram a remoção dos sólidos suspensos e dissolvidos. Posteriormente notou-se que os efeitos da tensão superficial na saída do reator, que interferem no regime do escoamento, podem ter sido influenciados pela diminuta escala do reator.

Leitão (2004) avaliou o comportamento de 11 reatores UASB, em escala piloto com volume de $120 \mathrm{~L}$ (cada unidade), baseado na eficiência de remoção de DQO, variabilidade da qualidade do efluente e estabilidade operacional e do $\mathrm{pH}$. Após os reatores terem alcançado o estado estacionário, o experimento foi realizado com 3 conjuntos de reatores, sendo: conjunto 1 formado por 5 reatores operados com TDH de $6 \mathrm{~h}$ e alimentados com diferentes concentrações de esgoto doméstico prépeneirado (92 $\pm 10 \mathrm{mg} . \mathrm{L}^{-1}, 195 \pm 15 \mathrm{mg} . \mathrm{L}^{-1}, 298 \pm 19 \mathrm{mg} . \mathrm{L}^{-1}, 555 \pm 36 \mathrm{mg} . \mathrm{L}^{-1} \mathrm{e}$ $816 \pm 45 \mathrm{mg} . \mathrm{L}^{-1}$, em termos de DQO); conjunto 2 composto por 4 reatores alimentados com mesma DQO afluente ( $\left.800 \mathrm{mg} . \mathrm{L}^{-1}\right)$, porém operados com diferentes TDH (6 h, 4 h, 2 h, 1 h); conjunto 3 formado por 4 reatores operados com mesma TCO $\left(\sim 3,3 \pm 0,2 \mathrm{kgDQO} \cdot \mathrm{m}^{-3} \cdot \mathrm{d}^{-1}\right)$ e TDH iguais aos aplicados no conjunto 2 .

O autor observou decréscimo na eficiência de remoção de matéria orgânica nos reatores alimentados com DQO inferior a $300 \mathrm{mg} . \mathrm{L}^{-1}$. Para os reatores alimentados com DQO superior a $300 \mathrm{mg} . \mathrm{L}^{-1}$, máximas eficiências foram alcançadas 
tanto para remoção de DQO bruta (59\%) quanto para DQO sedimentada (77\%). Mesmo alimentado com baixa concentração $\left(92 \pm 10 \mathrm{mg} . \mathrm{L}^{-1}\right)$, o reator foi capaz de remover aproximadamente $66 \%$ de DQO sedimentada devido à elevada eficiência de remoção de SS (97\%). Contudo, as baixas concentrações do substrato causaram variações na eficiência do reator com eventuais arrastes de sólidos no efluente, na variabilidade da DQO sedimentada no efluente e na eficiência de remoção de DQO.

As eficiências de remoção de DQO e de SS aumentaram com o aumento do TDH de $1 \mathrm{~h}$ para $6 \mathrm{~h}$. Porém os menores TDH causaram arraste de lodo no efluente, diminuindo a eficiência de remoção de SS de 93\% (TDH de 6 h) para 60\% (TDH de 1 h). Além disso, os menores tempos de contato e de retenção celular acarretaram em hidrólise incompleta do substrato. Os resultados também mostraram que a eficiência de remoção de DQO (sedimentada) tornou-se constante e igual a 77\% para valores de TDH superiores a $4 \mathrm{~h}$. Os experimentos mostraram que para TDH de $6 \mathrm{~h}$, os reatores UASB mantiveram aproximadamente a mesma eficiência de remoção de DQO independentemente da concentração do substrato. De acordo com o autor, a estabilidade do pH não foi característica do sistema anaeróbio aplicado, mas das características da água residuária. Algumas evidências de instabilidade do $\mathrm{pH}$ foram notadas apenas em condições operacionais extremas, tais como TDH de $2 \mathrm{~h}$ e/ou concentração do substrato menor do que $200 \mathrm{mg} . \mathrm{L}^{-1}$.

\subsubsection{EFEITO DA DURAÇÃO E FREQÜÊNCIA DOS DISTÚRBIOS}

Distúrbios tanto na forma de pulso quanto em degrau podem ocorrer devido a variações na concentração do poluente nas águas residuárias (HAMODA e ALSHAREKH, 1999; CABRAL, 2000; FRANCO et al., 2000a), na vazão (NACHAIYASIT e STUCKEY, 1997a,b; SKIADAS e LYBERATOS, 1998; FRANCO et al., 2000b), na temperatura, na capacidade de tamponamento, no pH, dentre outros fatores.

Em alguns casos, as variações na qualidade e na quantidade de esgotos domésticos podem ser amortecidas sem prejuízos à operação dos sistemas de tratamento. Em outros momentos, as flutuações ocorrem na forma de choques e os sistemas passam a necessitar de amortecimento para absorver essas mudanças 
instantâneas, caso contrário apresentarão redução na qualidade de seu efluente ou mesmo colapso em casos extremos.

Vários pesquisadores estudaram o comportamento dinâmico de diversas configurações de reatores anaeróbios submetidos a distúrbios na carga orgânica e hidráulica tanto na forma de pulso quanto em degrau (NACHAIYASIT e STUCKEY, 1997a,b; SKIADAS e LYBERATOS, 1998; EL-FARHAN e SHIEH, 1999; HAMODA e AL-SHAREKH, 1999).

Nachaiyasit e Stuckey (1997a) verificaram que o reator anaeróbio compartimentado submetido a cargas de choque orgânicas em degrau apresentou capacidade de tamponamento e de recuperação das condições iniciais após certo período de tempo. A estrutura compartimentada do reator não permitiu exposição da biomassa a baixos valores de $\mathrm{pH}$, e foi verificada predominância de microrganismos produtores de acetato e butirato.

Ao estudarem o comportamento do mesmo reator submetido a cargas de choque hidráulicas transientes (tipo pulso) e em degrau, Nachaiyasit e Stuckey (1997b) observaram que o reator apresentou queda na eficiência de remoção de DQO devido ao arraste de biomassa e surgimento de caminhos preferenciais no leito de lodo. Porém, os autores ressaltaram que o reator apresentou estabilidade operacional e pode ser submetido a cargas de carregamento elevadas.

Skiadas e Lyberatos (1998) avaliaram a influência das variações do período de ajuste de alimentação de um reator anaeróbio compartimentado (PABR). O reator (15 L) foi alimentado inicialmente com TCO de $0,2 \mathrm{gDQO} \cdot \mathrm{L}^{-1} \cdot \mathrm{d}^{-1}$ (glicose), mantido à temperatura de $35^{\circ} \mathrm{C}$ e período de ajuste de alimentação de $1 \mathrm{~d}$. Após essa etapa, o comportamento do reator foi avaliado para três períodos de ajuste de alimentação iguais a $1 \mathrm{~d}, 1,5 \mathrm{~d}$ e $2 \mathrm{~d}$, TCO de 4,55 gDQO.L $\mathrm{L}^{-1} \cdot \mathrm{d}^{-1}$ e TDH de $4 \mathrm{~d}$.

Os autores observaram que o reator demonstrou capacidade de adaptação às sobrecargas impostas, pois apresentou estabilidade em relação à eficiência de remoção de DQO dissolvida (98\% a 94\%) e à taxa de produção de biogás (de 2,9 L.L ${ }^{-1} \cdot d^{-1}$ para $\left.2,4 \mathrm{~L} \cdot \mathrm{L}^{-1} \cdot \mathrm{d}^{-1}\right)$.

El-Farhan e Shieh (1999) submeteram um reator anaeróbio com leito fluidizado a sobrecargas orgânicas de pulsos simples (16 h, 25 h e 60 h) e múltiplos (aumento triplo no pulso e duração igual a três vezes os tempos de detenção 
hidráulica de 6 h e 12 h). O reator foi alimentado com 6 g.L $L^{-1} \cdot d^{-1}$ de glicose e mantido à temperatura de aproximadamente $35^{\circ} \mathrm{C}$. Apesar de ter sido verificado acúmulo dos ácidos acético (100 mg. $\left.\mathrm{L}^{-1}\right)$ e propiônico $\left(60 \mathrm{mg} . \mathrm{L}^{-1}\right)$ no efluente, o reator apresentou eficiência de remoção do carbono orgânico total superior a $90 \%$ na aplicação do pulso simples de $60 \mathrm{~h}$.

Quando foram aplicados pulsos múltiplos de duração total de $30 \mathrm{~h}$ e $60 \mathrm{~h}$, o reator apresentou capacidade de remover a carga orgânica total em mais de $89 \%$, porém com concentrações dos ácidos acético (pico de $375 \mathrm{mg} . \mathrm{L}^{-1}$ ) e propiônico (pico de $270 \mathrm{mg} . \mathrm{L}^{-1}$ ) no efluente. Os autores notaram que as condições de estabilidade inicial foram alcançadas após $140 \mathrm{~h}$ da aplicação dos pulsos múltiplos. O reator amorteceu o efeito de arraste de biomassa devido à utilização de partículas do meio suporte poroso na retenção da biomassa e à aplicação de elevada taxa de recirculação no reator.

Cabral (2000) avaliou o desempenho e a estabilidade de um reator anaeróbio horizontal de leito fixo submetido a aumento progressivo da concentração de matéria orgânica afluente (2000 mgDQO.L ${ }^{-1}, 3000$ mgDQO.L ${ }^{-1}, 4000 \mathrm{mgDQO} . \mathrm{L}^{-1} \mathrm{e}$ 5000 mgDQO. $\mathrm{L}^{-1}$ ) e a cargas de choque orgânicas (três vezes superior às concentrações afluentes). A autora verificou que não houve significativa variação das concentrações de DQO e de ácidos voláteis no efluente do reator; o reator absorveu as cargas de choque aplicadas estabilizando-se após 15 h do início de sua aplicação; a eficiência de remoção de DQO do reator aumentou, mesmo com aplicação de concentração máxima do afluente.

Ribeiro et al. (2001) testaram cargas de choque orgânicas (aumento de cinco vezes a DQO afluente de 4 g.L $\mathrm{L}^{-1}$ ) e hidráulicas (1/5 do tempo de detenção hidráulica de $16 \mathrm{~h}$ ) em filtro anaeróbio de escoamento ascendente alimentado com substrato a base de ácido oléico. O filtro anaeróbio de $15 \mathrm{~L}$ foi inoculado com lodo de digestor anaeróbio municipal e mantido à temperatura de $35 \pm 1^{\circ} \mathrm{C}$. Com a aplicação das cargas orgânicas, os autores verificaram queda da eficiência de remoção de DQO de $22 \%$ e aumento da concentração de SSV para aproximadamente $7200 \mathrm{mg} . \mathrm{L}^{-1}$ no efluente. A minimização dos efeitos dos choques foi possível com o aumento da velocidade ascendente de $0,12 \mathrm{~m} \cdot \mathrm{h}^{-1}$ para $0,21 \mathrm{~m} \cdot \mathrm{h}^{-1}$. Para choques hidráulicos, os autores observaram redução de $43 \%$ na eficiência de remoção de DQO quando a velocidade 
ascendente aumentou de $0,12 \mathrm{~m} \cdot \mathrm{h}^{-1}$ para $0,41 \mathrm{~m} \cdot \mathrm{h}^{-1}$ e diminuição da concentração de SSV para $1860 \mathrm{mg} . \mathrm{L}^{-1}$ no efluente. Os autores obtiveram menor produção de biogás

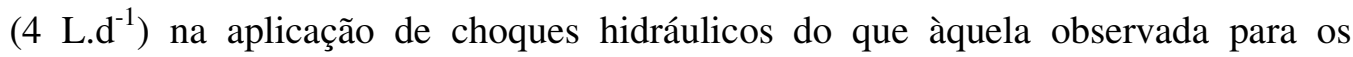
choques orgânicos $\left(7,7 \mathrm{~L} \mathrm{~d}^{-1}\right)$, possivelmente devido à redução da concentração de substrato que poderia ser mineralizado.

Stamatelatou et al. (2003a) operaram um reator anaeróbio compartimentado (PABR) de volume igual a $15 \mathrm{~L}$, mantido a temperatura de $35^{\circ} \mathrm{C}$, com TDH de $4 \mathrm{de}$ período de ajuste de alimentação de 2 d. Em três etapas distintas de operação, os autores submeteram o reator a aumentos sucessivos da carga orgânica afluente de glicose de 12,5 gDQO.L $\mathrm{L}^{-1}$ para 25 gDQO.L ${ }^{-1}, 50$ gDQO.L ${ }^{-1}$ e 75 gDQO.L ${ }^{-1}$ durante $20 \mathrm{~d}, 15 \mathrm{~d}$ e $7 \mathrm{~d}$, respectivamente. Esses aumentos foram mantidos até que o reator alcançasse o estado de equilíbrio dinâmico aparente em cada etapa.

Os autores verificaram que o reator apresentou queda na eficiência de remoção de DQO de $28 \%$ quando a concentração de matéria orgânica foi aumentada de 12,5 gDQO.L $\mathrm{L}^{-1}$ para 75 gDQO.L $\mathrm{L}^{-1}$. A capacidade de tamponamento do reator nessa etapa foi insuficiente na concentração de 75 gDQO. $\mathrm{L}^{-1}$, pois os autores verificaram concentrações dos ácidos acético e propiônico de aproximadamente $2000 \mathrm{mg} . \mathrm{L}^{-1}$ e dos ácidos butírico e valérico de aproximadamente $4000 \mathrm{mg} . \mathrm{L}^{-1}$ no efluente, que acarretou no decréscimo do $\mathrm{pH}$ para 4,0 e conseqüente desbalanceamento entre as etapas do processo.

Dentro desse contexto alguns autores avaliaram o comportamento de reatores UASB submetidos a variações de cargas de choque orgânicas e hidráulicas (PAULA JR, 1992; GAVALA et al., 1999; PALENZUELA-ROLLON et al., 2001; FRANCO et al., 2002a; FRANCO et al., 2002b; SANCHEZ et al., 2005).

Para avaliar o desempenho de reatores anaeróbios submetidos a aumentos progressivos na DQO e concentração de sulfeto, Paula Jr. (1992) operou dois reatores UASB (10,5 L cada), inoculados com lodo anaeróbio digerido proveniente de uma estação de tratamento de águas residuárias. Os reatores foram alimentados com substrato sintético com concentração inicial de matéria orgânica de $2000 \mathrm{mgDQO} . \mathrm{L}^{-1}$ à base de água, glicose, mistura de micronutrientes, acetato de amônia, metanol e sulfato de níquel e operados com tempo de detenção hidráulica igual a 15,6 h e vazão de alimentação constante de 16,0 L.d $\mathrm{d}^{-1}$. 
A DQO foi aumentada progressivamente a cada 15 dias para $2000 \mathrm{mg} . \mathrm{L}^{-1}$, 4000 mg.L ${ }^{-1}$, 6000 mg.L $L^{-1}, 8000$ mg.L ${ }^{-1}$, 10000 mg.L ${ }^{-1}$ e 12000 mg.L.$^{-1}$. O reator (1) apresentou diminuição na eficiência de remoção de DQO de aproximadamente $20 \%$ quando as concentrações afluentes variaram de $1780 \mathrm{mg} . \mathrm{L}^{-1}$ a $9700 \mathrm{mg} . \mathrm{L}^{-1}$ e as cargas orgânicas volumétricas variaram de 2,7 kgDQO. $\mathrm{m}^{-3} \cdot \mathrm{d}^{-1}$ a $14,8 \mathrm{kgDQO} \cdot \mathrm{m}^{-3} \cdot \mathrm{d}^{-1}$. O autor verificou menor produção de biogás e maior concentração de sólidos suspensos no efluente, provavelmente devido à inibição da atividade metanogênica pela concentração de ácidos voláteis no reator. O reator (2) foi submetido a aumentos progressivos na concentração de sulfeto no substrato sintético que resultaram de 10 mg.L. $\mathrm{L}^{-1}, 25 \mathrm{mg} . \mathrm{L}^{-1}$, $50 \mathrm{mg} . \mathrm{L}^{-1}, 100 \mathrm{mg} . \mathrm{L}^{-1}, 150 \mathrm{mg} . \mathrm{L}^{-1}$, $200 \mathrm{mg} . \mathrm{L}^{-1}$, 300 mg.L $\mathrm{L}^{-1}$, $500 \mathrm{mg} . \mathrm{L}^{-1}$ e $800 \mathrm{mg} . \mathrm{L}^{-1}$, a cada 15 ou 20 dias após a adaptação do reator às dosagens aplicadas.

$\mathrm{O}$ autor verificou que houve aumento na DQO afluente e efluente quando foram aplicadas as concentrações mais elevadas de sulfeto e variação nas eficiências de remoção de DQO de $98 \%$ a $70 \%$ para concentrações de sulfeto variando de zero a $500 \mathrm{mg} . \mathrm{L}^{-1}$. Ele concluiu que, de maneira geral, ambos os reatores foram capazes de absorver os aumentos progressivos das cargas a que foram submetidos.

Gavala et al. (1999) estudaram o comportamento de um reator UASB (10 L) alimentado com água residuária diluída de laticínio com 2500 mgDQO.L ${ }^{-1}$. Com o objetivo de determinar a taxa de carregamento orgânica máxima possível (TCO) a ser aplicada no reator UASB, os autores aumentaram gradualmente a DQO afluente (reduzindo a taxa de recirculação de $52 \mathrm{~mL} \cdot \mathrm{min}^{-1}$ ) e variaram o TDH para obter eficiência de remoção de DQO. Os autores observaram que o reator alcançou máxima eficiência de remoção de DQO, de aproximadamente $98 \%$, quando operado com TDH de 6 d e DQO afluente igual a 37 g.L $\mathrm{L}^{-1}$ (TCO igual a 6,2 gDQO.L ${ }^{-1} \cdot \mathrm{d}^{-1}$ ). Quando a DQO afluente aumentou para 42 g.L $\mathrm{L}^{-1}$ (TCO igual a 7,5 gDQO.L $\mathrm{L}^{-1} \cdot \mathrm{d}^{-1}$ ), a eficiência de remoção de DQO diminuiu para a faixa de $85 \%$ a 90\%. Para valores de DQO afluente superiores a 42 g.L $\mathrm{L}^{-1}$, o reator apresentou queda na eficiência de remoção de DQO, na produção de biogás e nos valores de $\mathrm{pH}$.

Os autores operaram paralelamente um digestor convencional (8 L $)$ alimentado com água residuária não diluída de laticínio com 60 gDQO.L ${ }^{-1}$ e redução progressiva do TDH para comparar seu desempenho com o do reator UASB. Foi 
possível verificar que o digestor alcançou máxima TCO igual a 2,3 gDQO.L $\mathrm{L}^{-1} \cdot \mathrm{d}^{-1}$ quando operado com TDH igual a 26 d. A eficiência de remoção de DQO variou de $83 \%$ a $92 \%$ com TDH variável na faixa de 26 d a $40 \mathrm{~d}$.

Palenzuela-Rollon et al. (2001) compararam o desempenho de dois reatores UASB, mantidos à temperatura de aproximadamente $30^{\circ} \mathrm{C}$, inoculados com lodo anaeróbio proveniente de estação de tratamento de água residuária de cervejaria e alimentados com substrato sintético que simulava água residuária de processamento de peixes com diferentes concentrações de lipídeos.

Os autores verificaram que o reator 1 (3,6 L), operado com TDH igual a 11,3 h, TCO igual a 5,4 gDQO. $\mathrm{L}^{-1}$ e DQO afluente igual a $2718 \mathrm{mg} . \mathrm{L}^{-1}$, alcançou eficiências de remoção de DQO e de conversão de DQO a metano iguais a 78\% e $61 \%$, respectivamente. As concentrações de STV e de ST no efluente mantiveram-se na faixa de 5 g.L - $^{-1}$ a 8 g.L $L^{-1}$ e de 8 g.L $L^{-1}$ a 12 g.L - $^{-1}$, respectivamente. O reator $2(2 \mathrm{~L})$, operado com TDH igual a 12,3 h, TCO igual a 8,3 gDQO.L $\mathrm{L}^{-1}$ e DQO afluente igual a $3529 \mathrm{mg} . \mathrm{L}^{-1}$, apresentou eficiências de remoção de DQO e de conversão de DQO a metano iguais a $92 \%$ e $47 \%$, respectivamente. As concentrações de sólidos voláteis e de sólidos totais no efluente mantiveram-se na faixa de 7 g.L ${ }^{-1}$ a 16 g.L ${ }^{-1}$ e de 20 g.L $L^{-1}$ a 30 g. $L^{-1}$, respectivamente.

Também foi operado um sistema de duas fases composto por dois reatores UASB submetidos à elevada concentração do mesmo esgoto, sendo o reator 2 da etapa anterior responsável pela primeira fase desse sistema. No sistema, o reator 2 $(8,8 \mathrm{~L})$ foi operado com TDH igual a $6,1 \mathrm{~h}$, TCO igual a 15,1 gDQO.L ${ }^{-1}$ e DQO afluente igual a $4025 \mathrm{mg} \cdot \mathrm{L}^{-1}$. Os autores observaram eficiência de remoção de DQO variável de $55 \%$ a $58 \%$ para reator operado individualmente e combinado a outro reator. Os autores recomendaram a aplicação de reatores UASB no tratamento de águas residuárias contendo baixas concentrações de lipídeos e aplicação de sistema de duas fases para tratamento de águas residuárias com elevada concentração desses compostos.

Franco et al. (2002a) operaram três reatores UASB com volume igual a 0,8 L e mantidos a temperatura de $37^{\circ} \mathrm{C}$. Os reatores foram inoculados com lodo floculento de reator UASB tratando água residuária de indústria de enlatados de peixes e alimentados com solução de dextrose monohidratada de 5 gDQO.L ${ }^{-1}$. Os dois 
primeiros reatores (P1 e P2) foram equipados com um aparato de pulsação, confeccionado em membrana elástica, que controlava a taxa de recirculação e a vazão afluente. $\mathrm{O}$ aparato de pulsação de membrana elástica (PME) consiste de um tubo elástico conectado a uma válvula com operação controlada por timer ou sistema computadorizado. Os reatores P1 (taxa de recirculação) e P2 foram operados com vazão pulsante e TDH igual a 0,7 d e o terceiro reator foi operado sem pulsação (NP) e TDH igual a 1,4 d. As taxas de carregamento orgânicas aplicadas foram iguais a 12,5 kgDQO. $\mathrm{m}^{-3} \cdot \mathrm{d}^{-1}, 14,0 \mathrm{kgDQO} \cdot \mathrm{m}^{-3} \cdot \mathrm{d}^{-1}$ e $6,0 \mathrm{kgDQO} \cdot \mathrm{m}^{-3} \cdot \mathrm{d}^{-1}$ nos reatores P1, P2 e $\mathrm{NP}$, respectivamente.

$\mathrm{O}$ reator $\mathrm{P} 2$ apresentou melhor capacidade de tamponamento do meio ao longo de todo o experimento, enquanto que no reator NP foi necessário diminuir a TCO para 2,0 kgDQO. $\mathrm{m}^{-3} \cdot \mathrm{d}^{-1}$ para que o reator recuperasse sua condição de estabilidade inicial.

A eficiência de remoção de DQO do reator P1 diminui de $98 \%$ para $85 \%$ (em média) quando operado com TCO superior a $8,0 \mathrm{kgDQO} \cdot \mathrm{m}^{-3} \cdot \mathrm{d}^{-1}$. O reator P2 alcançou eficiência de aproximadamente $95 \%$ ao longo de todo o experimento, mesmo com aplicação de valores elevados de TCO. O reator NP obteve menor eficiência de remoção de DQO (aproximadamente 50\%) devido ao arraste de sólidos no efluente. De acordo com os autores, a vazão pulsante contribuiu para a desgaseificação do manto de lodo, o que evitou perda de biomassa no efluente quando a produção de biogás era elevada.

Franco et al. (2002b) estudaram a influência da vazão de pulsação na partida e operação do mesmo aparato experimental usado por Franco et al. (2002a). Na primeira fase de operação, o volume do reator P1 foi mantido constante com decréscimo da taxa de recirculação e aumento da concentração de substrato e o volume do reator P2 foi aumentado proporcionalmente à taxa de carregamento orgânico (TCO). Na segunda fase, a freqüência de pulsação foi diminuída para P1 e aumentada para $\mathrm{P} 2$.

Na primeira fase, os reatores P1, P2 alcançaram eficiência de remoção de DQO de $94 \%$ e o reator NP de $85 \%$; porém quando a TCO foi aumentada para 12,5 kgDQO. $\mathrm{m}^{-3} \cdot \mathrm{d}^{-1}$, houve queda de $10 \%$ na eficiência de remoção de DQO do reator P2. Com o aumento da TCO para 20,0 kgDQO. $\mathrm{m}^{-3} \cdot \mathrm{d}^{-1}$ (DQO afluente igual a $10 \mathrm{~g} . \mathrm{L}^{-1}$ ), 
P1 e P2 alcançaram 95\% de eficiência de remoção de DQO; enquanto que no reator NP a eficiência decresceu para 50\% devido ao arraste de biomassa do reator causada pelo aumento da produção de biogás. Outro fator que contribuiu para a queda da eficiência do reator foi a presença de ácido acético $\left(0,82\right.$ g. $\left.\mathrm{L}^{-1}\right)$ e de ácido propiônico $\left(0,47\right.$ g.L $\left.L^{-1}\right)$ no efluente de NP.

Nos reatores P1 e P2 na segunda fase, os autores observaram que a pulsação favoreceu a saída de gás do manto de lodo quando a produção de biogás aumentou, o que evitou arraste de biomassa no efluente, a formação de caminhos preferenciais no manto de lodo e melhorou a transferência de massa. O reator NP apresentou menor eficiência de remoção de DQO, em torno de $80 \%$.

Sanchez et al. (2005) avaliaram o comportamento de um reator anaeróbio de manta de lodo em escala de laboratório (5 L) alimentado com água residuária contendo mistura de fezes e urina de suínos (rica em carboidratos). O substrato apresentou valores médios de pH, DQO total e concentração de SSV iguais a

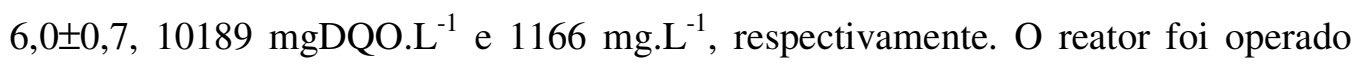
com vazão média afluente de 0,625 L.d $\mathrm{d}^{-1}$ e TDH de $8 \mathrm{~h}$ e mantido a temperatura de $30 \pm 3^{\circ} \mathrm{C}$. Os autores variaram as taxas de carregamento orgânicas volumétricas de 1,$0 ; 1,4 ; 1,6 ; 2,0 ; 2,7 ; 4,1$ a 8,1 gDQO.L ${ }^{-1} \cdot \mathrm{d}^{-1}$ (TDH de 8, 6, 5, 4, 3, 2 a 1 d) durante 7 semanas para cada variação.

Os autores verificaram que o sistema apresentou queda na eficiência de remoção de DQO bruta de 18,6\%, DQO filtrada de 19,7\%, SST de 27,1\% e SSV de $42,6 \%$, com aplicação da taxa máxima de carregamento orgânica volumétrica de 8,1 gDQO.L $\mathrm{L}^{-1} \cdot \mathrm{d}^{-1}$. O sistema não apresentou capacidade de tamponamento, com conseqüente aumento na concentração de ácidos graxos voláteis (1211 mg. $\left.\mathrm{L}^{-1}\right) \mathrm{e}$ queda do $\mathrm{pH}$. A produção de gás metano decresceu 33\% e a concentração de gás carbônico aumentou 63\%. Para as taxas de carregamento orgânica volumétrica que variaram de 1,$0 ; 1,4 ; 1,6 ; 2,0 ; 2,7$ a 4,1 gDQO. $\mathrm{L}^{-1} \cdot \mathrm{d}^{-1}$, o sistema apresentou capacidade de tamponamento com $\mathrm{pH}$ variável de 7,4 a 7,2 e eficiências de remoção de DQO bruta de $40 \%$, DQO filtrada de $45 \%$ a $86 \%$, SST de $84 \%$ a $41 \%$ e SSV de $83 \%$ a $58 \%$. As produções de gás metano e de gás carbônico variaram de $66 \%$ a $46 \%$ e de $32 \%$ a $61 \%$, respectivamente. Os autores concluíram que o aumento da taxa de carregamento orgânica volumétrica promoveu queda da eficiência de remoção de 
DQO bruta, DQO filtrada, SST e SSV e produção de gás metano, devido ao aumento da concentração de matéria orgânica e ácidos graxos voláteis no efluente.

\subsection{MODELOS MATEMÁTICOS}

Modelos de processos biológicos têm sido desenvolvidos com o objetivo de melhorar a compreensão das etapas envolvidas na conversão biológica e conseqüentemente otimizar os projetos de sistemas de tratamento. Além disso, os dados experimentais obtidos visam validar os modelos e auxiliar na comparação entre diferentes sistemas.

Como os processos anaeróbios são suscetíveis a mudanças operacionais que podem causar a falência do processo, é de fundamental importância a aplicação de modelos matemáticos que possam prever possíveis falhas do processo antes que elas ocorram. Com a previsão das falhas é possível tomar medidas de proteção para que o sistema seja capaz de recuperar suas condições iniciais (MARSILI-LIBELLI e BENI, 1996).

Apesar de nos últimos anos ter havido um progresso significativo na modelação matemática de processos anaeróbios de tratamento, apenas recentemente foi apresentado um modelo abrangente para a digestão anaeróbia (BATSTONE et al., 2002a,b).

De modo geral, os modelos até então limitavam-se a descrever sistemas específicos para substratos também particulares. Apesar dessas limitações, alguns desses modelos resultaram em equacionamentos práticos e ainda úteis, especialmente para avaliação preliminar de respostas dinâmicas desses reatores. Alguns dos modelos propostos incorporaram as características hidrodinâmicas do reator, enquanto outros tiveram como objetivo apenas a descrição do fenômeno da digestão anaeróbia. Este é o caso do modelo ADM 1 proposto por Batstone et al. (2002a,b). O ADM1 pode ser incorporado a qualquer tipo de reator, desde que o processo de transporte dos componentes, entre diferentes regiões do reator, seja conhecido e utilizado no balanço geral de massa.

A descrição detalhada do modelo ADM1 será apresentada posteriormente no item Material e Métodos, uma vez que o modelo foi aplicado como ferramenta 
computacional para melhor compreender o comportamento do reator UASB operado nessa pesquisa.

Provavelmente, um dos primeiros modelos matemáticos de caráter abrangente para aplicação em reatores UASB foi proposto por Bolle et al. (1986) na Holanda. Nesse modelo, o reator é dividido em três compartimentos em série, sendo que o leito e o manto de lodo são considerados perfeitamente misturados em relação à fase líquida e o sedimentador interno é modelado como tubular ideal. O modelo considera cinética de Andrews para conversão de ácidos graxos a dióxido de carbono e metano e regime de escoamento contínuo. Os autores apresentam respostas para variáveis de estado observáveis ou difíceis de serem observadas como: altura do leito de lodo, concentração de lodo no manto, fluxos de curto-circuito, eficiência, pH e DQO em estados pseudo-estacionário e transiente.

A partir de simulações que utilizaram esse modelo, Bolle et al. (1986) concluíram que as variações na vazão afluente contribuíam para crescimento da produção gasosa e da DQO efluente. Com o aumento da eficiência do sedimentador interno, o arraste de biomassa no efluente do reator poderia ter sido evitado e as cargas de choque hidráulicas amortecidas.

Desde então, diversos modelos são encontrados na literatura, alguns preparados para casos específicos, como por exemplo Labib et al. (1993), Edgehill (1998), Skiadas et al. (2000), Stamatelatou e Lyberatos (2002), Stamatelatou et al. (2003b), outros para aplicação geral, como por exemplo Thomas e Nordstedt (1993) e Marsili-Libelli e Beni (1996).

Tradicionalmente, a cinética da digestão anaeróbia tem sido representada por modelos de $1^{\text {a }}$ ordem e tipo Monod para consumo de substrato e crescimento microbiano por autores como Paula Jr. e Foresti (1992), Zaiat (1996), Castillo et al. (1999), Batstone et al. (2002a,b), Rodríguez-Martínez et al. (2002) e Chavéz et al. (2005).

Thomas e Nordstedt (1993) desenvolveram um modelo de digestão anaeróbia para vários tipos de reatores alimentados com substratos de fácil e de difícil degradabilidade. Aplicaram o método de integração de Runge-Kutta de $4^{\mathrm{a}}$ ordem, modelo cinético tipo Monod para as velocidades de crescimento bacteriano e decaimento endógeno e modelo cinético de $1^{\mathrm{a}}$ ordem para velocidades de consumo 
de substrato. Os reatores de leito fixo e fluxo contínuo foram considerados como mistura completa (formados por vários compartimentos de mesmo tamanho), com tempo de retenção celular de 50 d e tempo de detenção hidráulica de 6 h. Considerando apenas dois parâmetros na descrição do substrato, admitiram que os resíduos sólidos foram digeridos pela microbiota em longos tempos de retenção celular.

Os autores validaram o modelo ao compararem as respostas obtidas nas simulações com dados reportados na literatura. Os dados obtidos para a produção de metano apresentaram correlação de 95\%, que indicou resposta favorável do modelo aplicado como ferramenta na avaliação de valores de eficiências de conversão e de parâmetros cinéticos de diversos tipos de reatores e substratos.

Labib et al. (1993) descreveram as respostas em estado estacionário e transiente de consórcio anaeróbio, utilizando butirato e acetato como substrato para simulação de sobrecargas de ácidos. A equação de Monod foi empregada para descrever a conversão de butirato pelos organismos acetogênicos produtores de hidrogênio. As reações de crescimento microbiano e de consumo de substrato somadas a balanços de massa, resultaram em equações diferenciais ordinárias para reator de mistura completa, as quais foram resolvidas numericamente. O reator foi submetido a mudanças de carga orgânica com concentração elevada de acetato e concentração constante de butirato.

Os autores verificaram que, com aumento da concentração de acetato, houve perda de biomassa e acúmulo de ácidos, o que causou queda do $\mathrm{pH}$ e colapso do sistema. As sobrecargas de hidrogênio não influenciaram a estabilidade do sistema, uma vez que a pressão parcial desse gás foi controlada pela atividade dos microrganismos hidrogenotróficos. O modelo foi eficiente na previsão da resposta do sistema a sobrecargas orgânicas.

Marsili-Libelli e Beni (1996) desenvolveram modelo matemático simplificado para reatores anaeróbios submetidos a cargas de choque orgânicas. $O$ modelo considerou o substrato dissolvido e convertido em ácidos graxos voláteis e $\mathrm{CO}_{2}$. Os ácidos foram divididos em dois grupos, um representado pelo ácido acético e outro, pelos ácidos propiônico e butírico. As equações do modelo foram obtidas por meio de equações de balanço de massa em reator de mistura completa, biomassa 
imobilizada e variáveis representativas do consumo de substrato, crescimento de microrganismos acidogênicos e metanogênicos e dinâmica do dióxido de carbono. Os autores utilizaram a expressão de Monod modificada para o consumo de substrato, incorporando fatores de produção de biomassa acidogênica, ácidos graxos voláteis e $\mathrm{CO}_{2}$. O modelo cinético de inibição de Haldane foi aplicado na produção de ácido acético.

Quando o reator foi submetido a cargas de choque de ácido acético, os autores verificaram maior atividade dos microrganismos metanogênicos, decréscimo do pH e possibilidade de recuperação do sistema após 10 h. Os autores concluíram que o modelo apresentou concordância satisfatória com os dados experimentais, podendo ser empregado na previsão de cargas de choque e no controle de processos.

Edgehill (1998) monitorou a resposta de um filtro percolador em escala de laboratório submetido a variações em degrau (150 mg.L $\mathrm{L}^{-1}, 165 \mathrm{mg} . \mathrm{L}^{-1}$ e $\left.366 \mathrm{mg} . \mathrm{L}^{-1}\right)$ na concentração do substrato a base de pentaclorofenol (PCP) durante 300 dias. Os modelos para reator de mistura completa e tubular ideal, adotando velocidade específica de crescimento microbiano constante $\left(0,15 \mathrm{mg} \cdot \mathrm{mg}^{-1}\right)$ e concentração mínima de PCP (0,5 mg. $\left.\mathrm{L}^{-1}\right)$ antes da aplicação das cargas de choque foram adotados no ajuste dos dados experimentais obtidos.

O modelo para reator em mistura completa apresentou acuracidade em seis das sete curvas de resposta da concentração efluente variando no tempo. Esse modelo adotou como parâmetros velocidade específica de crescimento, concentração de biomassa e tempo de detenção hidráulica $(0,37 \mathrm{~h})$. O modelo para mistura completa apresentou melhor desempenho que o modelo tubular ideal tanto para sobrecargas (degrau) na concentração de PCP variando de $12 \mathrm{mg} . \mathrm{L}^{-1}$ a $165 \mathrm{mg} . \mathrm{L}^{-1}$, quanto para cargas de choque repetitivas variando de $20 \mathrm{mg} . \mathrm{L}^{-1}$ a $150 \mathrm{mg} . \mathrm{L}^{-1}$.

$\mathrm{O}$ autor concluiu que a aproximação do modelo usada nesse estudo parece ter aplicabilidade limitada na previsão e controle de processos devido a contínua eficiência observada experimentalmente, mesmo quando o filtro foi submetido a aumento da carga de choque. Com o ajuste de dados, os parâmetros estimados podem ser úteis na comparação com àqueles obtidos e na aplicação de outros modelos mais detalhados que contemplem efeitos de difusão. 
Skiadas et al. (2000) desenvolveram modelo dinâmico para reator anaeróbio compartimentado com alimentação periódica operado por Skiadas e Lyberatos (1998). A principal diferença entre os resultados do modelo e os resultados experimentais da operação do reator foi atribuída ao elevado grau de retenção de biomassa por precipitação em seus compartimentos. Assim, os autores estimaram valores ótimos para um fator de retenção de biomassa $(\delta)$ através da simulação dos resultados experimentais de DQO efluente, sem manipulação dos parâmetros cinéticos. O modelo considerou comportamento hidrodinâmico de quatro reatores de mistura completa em série; modelo cinético de Monod para degradação da glicose a metano; equivalência das concentrações de glicose e dos produtos de sua conversão (lactato, produto intermediário desconhecido, propionato, acetato) em cada um dos quatro compartimentos em relação às concentrações efluentes do mesmo compartimento.

$\mathrm{O}$ valor de $\delta$ foi estimado por meio de ajuste dos resultados experimentais obtidos por Skiadas e Lyberatos (1998) em três estados estacionários periódicos pelo método dos mínimos quadrados, ou seja, para períodos de ajuste de alimentação (T) iguais a $1 \mathrm{~d}, 1,5 \mathrm{~d}$ e $2 \mathrm{~d}$. O sistema de equações diferenciais foi resolvido pelo método de Runge-Kutta de $4^{\mathrm{a}}$ ordem. Para tempo de ajuste de alimentação de $1 \mathrm{~d}$, os autores obtiveram valor de $\delta$ igual a 0,936 e verificaram similaridade entre as concentrações de biomassa obtidas com o modelo $\left(34\right.$ g. $\left.\mathrm{L}^{-1}\right)$ e com a operação do reator $\left(31 \mathrm{~g} . \mathrm{L}^{-1}\right)$.

O modelo indicou valores ótimos de TDH para cada período de ajuste de alimentação nas simulações para seis diferentes tempos de detenção hidráulica ( 2 h, 3 h, 4 h, 5 h, 6 h); maior taxa de remoção de DQO e de produção de metano nas simulações com menores valores de T e de TDH; menor taxa de produção de metano em relação à taxa produzida experimentalmente, uma vez que o modelo não considerou a taxa de metano produzida a partir do $\mathrm{H}_{2}$ e do $\mathrm{CO}_{2}$.

Stamatelatou e Lyberatos (2002) desenvolveram modelo para simulação das condições operacionais de um reator anaeróbio compartimentado $(15 \mathrm{~L})$ alimentado periodicamente com substrato à base de gelatina $\left(12,5\right.$ g.L $\left.\mathrm{L}^{-1}\right)$ e submetido à variação de $100 \%$ na concentração do substrato ou no tempo de detenção hidráulica e em estado estacionário. $\mathrm{O}$ modelo considera o reator dividido em duas partes: inferior 
(maior concentração de biomassa) e superior (menor concentração de biomassa, que pode ser considerada uniformemente distribuída devido à mistura causada pela produção de biogás). Ao modelo foi incorporada cinética de degradação da gelatina, limitada pela ação de quatro grupos de microrganismos (acidogênicos, acetogênicos, acetoclásticos e metanogênicos hidrogenotróficos). Os parâmetros cinéticos $v_{\text {máx }}$ igual a $10,7 \mathrm{~d}^{-1}$ e $\mathrm{K}_{\mathrm{m}}$ igual a $246,78 \mathrm{mg} \cdot \mathrm{L}^{-1}$ (gelatina) foram determinados por regressão linear dos dados do trabalho de Breure et al. (1986) ${ }^{2}$ apud Stamatelatou e Lyberatos (2002).

O modelo considerou taxa de transferência ascensional de cada grupo de microrganismo ocasionada principalmente pelo fluxo ascensional líquido, proporcional à taxa de produção de biogás da parte inferior; taxa de transferência de sólidos descendente ocasionada parcialmente pelo efeito da gravidade nas partículas de lodo; concentração de biomassa e velocidade de sedimentação como parâmetros de ajuste do modelo.

Os autores verificaram que não foi necessário realizar ajustes dos parâmetros cinéticos para melhorar a resposta dinâmica do modelo. A simulação do estado transiente demonstrou arraste de biomassa no efluente do reator imediatamente após a redução do $\mathrm{TDH}$, provavelmente devido à produção intensa de biogás. O modelo indicou que o reator degradou a gelatina durante operação periódica estacionária e de sobrecarga e foi capaz de predizer com sucesso as variações da resposta oscilante do reator.

Stamatelatou et al. (2003b) desenvolveram modelo de digestão anaeróbia para o aparato experimental reportado por Stamatelatou et al. (2003a). O modelo considerou cada compartimento do reator dividido em duas seções de volume variável, que interagiam, porém com volume total constante. A seção inferior possuía maior concentração de biomassa em relação à seção superior, enquanto que a concentração de biomassa foi considerada uniformemente distribuída na seção superior, devido à mistura causada pela produção de biogás. A biomassa responsável

2 Breure et al. (1983). Acidogenic fermentation of protein carbohydrate mixtures by bacterial-populations adapted to one of the substances in anaerobic chemostat cultures. Appl. Microbiology Biotechnology, 23, n.3-4, p. 245-249, janeiro. 
pela conversão da glicose no modelo foi dividida em microrganismos acidogênicos, acetogênicos e metanogênicos. Foi utilizado o modelo cinético modificado $<$ METHANE $>$ descrito por Vavilin et al. (2000) para reatores de mistura completa e modelo cinético de Monod para inibição dos microrganismos devido à presença de substrato. O modelo aplicou os resultados experimentais obtidos por Vavilin et al. (1995) como valores para os parâmetros cinéticos $\mathrm{Y}, \mathrm{K}_{\mathrm{S}}, \mathrm{k}_{\mathrm{d}}$ (coeficiente de decaimento) e $\rho_{\mathrm{m}}$ (taxa específica máxima de consumo de substrato limitante). As constantes de inibição $\left(\mathrm{K}_{\mathrm{I}}\right)$ e a concentração inicial de biomassa foram determinadas por calibração visual do modelo.

O modelo indicou maior inibição dos microrganismos acetogênicos que degradam ácido propiônico, seguidos pelos microrganismos acetogênicos que degradam butirato e metanogênicos acetoclásticos; maior tolerância dos microrganismos acidogênicos a concentrações elevadas de ácidos graxos voláteis.

Os autores concluíram que o modelo apresentou respostas que apresentaram concordância com os dados experimentais apresentados por Stamatelatou et al. (2003a) no qual foram efetuadas simulações de três aumentos sucessivos na taxa de carregamento orgânico.

\subsection{ANAEROBIC DIGESTION MODEL No 1}

Batstone et al. (2002a,b) desenvolveram modelo generalizado de digestão anaeróbia (ADM 1) para diversos tipos de sistemas, o qual inclui etapas bioquímicas representadas pela desintegração de partículas homogêneas em carboidratos (aplicados comumente em sistemas de alta taxa), proteínas e lipídeos; hidrólise desses substratos particulados em aminoácidos, açúcares e ácidos graxos de cadeia longa; acidogênese de açúcares e aminoácidos em ácidos graxos voláteis e hidrogênio; acetogênese de ácidos graxos de cadeia longa e ácidos graxos voláteis em acetato e metanogênese de acetato e hidrogênio/ $\mathrm{CO}_{2}$; além disso, o modelo também considerou etapas físico-químicas representadas pela associação e dissociação iônica e por transferência gasosa. Os modelos cinéticos de Monod e de $1^{\mathrm{a}}$ ordem foram aplicados na descrição do crescimento microbiano e do consumo de substrato, respectivamente. 
O modelo apresenta limitações devido à grande quantidade de variáveis de entrada que devem ser conhecidas, sendo algumas de difícil determinação, tais como: caracterização detalhada dos componentes do esgoto (monossacarídeos, aminoácidos, ácidos graxos de cadeia longa), parâmetros cinéticos de crescimento celular e de consumo de substrato, parâmetros físico-químicos, constantes de inibição, dentre outros.

Algumas aplicações do modelo ADM1 tem sido reportadas na literatura a fim de ilustrar: o comportamento de reatores anaeróbios no tratamento de águas residuárias dos mais diversos tipos, a acuracidade do modelo ADM1, as dificuldades e limitações do modelo, propostas de metodologias para padronização do código do modelo de modo a viabilizar sua aplicação em diversos simuladores.

Bernard et al. (2006) propuseram uma metodologia para determinar a estrutura de uma matriz $K$ pseudo-estacionária de um modelo baseado em equações de balanço de massa. A estrutura da matriz consiste na estimativa do número de reações (ou biomassas) independentes que representem a transferência de massa que ocorre dentro do reator, fornecendo assim a dimensão da matriz $K$. Os autores consideraram as concentrações e os balanços de vazão afluente e efluente medidos durante intervalo de tempo e variáveis com o tempo. O método foi aplicado no modelo proposto por Bernard et al. (2001) que considera uma ou duas reações e no modelo ADM1 que considera sete reações envolvidas no processo de digestão anaeróbia.

No modelo de Bernard et al. (2001), o método proposto utilizou os dados experimentais obtidos com a operação de um reator anaeróbio de leito fixo, em escala piloto, com volume de $1 \mathrm{~m}^{3}$. Em análise de variância foi verificado que o coeficiente de variabilidade resultou de $83,2 \%$ e 97,8\% para uma reação (biomassa) e duas biomassas, respectivamente. Essa análise indicou a capacidade do modelo de reproduzir os dados experimentais considerando apenas uma biomassa envolvida no processo.

O modelo ADM1 foi implementado com utilização do programa computacional Matlab Simulink e calibrado apenas com alterações no tempo de retenção celular. Os autores consideraram os dados gerados pelo modelo para representar virtualmente o processo de tratamento. Esse modelo apresenta maior 
complexidade por descrever mais detalhadamente as várias etapas envolvidas no processo de digestão anaeróbia. O modelo apresentou resultados similares àqueles obtidos experimentalmente. Por contemplar maior número de reações, esse modelo apresentou resultados mais detalhados dos ácidos voláteis, sendo capaz de prever possíveis acúmulos de ácido propiônico.

Bernard et al. (2006) ressaltaram ainda que mesmo modelos mais simples podem reproduzir algumas variáveis com acuracidade. Já os modelos mais complexos podem ser simplificados, o que justifica sua aplicação como base para algoritmos de controle, programas de sensores e falha de detecção. Quanto mais complexos os modelos, maiores serão as possibilidades de aplicação em condições reais. Assim seria possível prever antecipadamente o comportamento dos processos, reduzindo o número de longos e dispendiosos experimentos a serem realizados.

De Gracia et al. (2006) propuseram uma metodologia sistemática com balanços de massa e de cargas em modelos dinâmicos para determinação dos parâmetros estequiométricos e de conversão. A metodologia foi baseada no fracionamento das massas e das cargas e na estimativa da DQO. Esta aproximação tornou mais simples o cálculo automático de todos os coeficientes estequiométricos em diferentes unidades de medida, bem como o estudo da DQO, carga ou fluxos de massa.

O modelo ADM1 foi aplicado como exemplo dessa metodologia para caracterizar os componentes envolvidos no processo e calcular os parâmetros de conversão para identificação de possíveis desequilíbrios. A visualização dos processos envolvidos foi possível pela matriz estequiométrica de Petersen e pela construção dos fluxos de massa. A implementação do ADM1 em equações diferenciais considerou 39 componentes, 22 processos biológicos, 3 processos de transferência cinética de gás-líquido e 6 processos cinéticos de ácido-base. Os autores obtiveram 60,16 gDQO de $\mathrm{CH}_{4}$ (equivalente a 0,94 mols) e 21,27 g de $\mathrm{CO}_{2}$ (equivalente a 0,48 mols), o que indicou coerência com os dados reportados por Gujer e Zhender (1983) ${ }^{3}$ apud de Gracia et al. (2006).

\footnotetext{
${ }^{3}$ Gujer, W e Zhender, A. (1983). Conversion process in anaerobic digestion. Water Science and Technology, v.15, p.127-167.
} 
Os autores observaram adaptação do modelo ADM1 à metodologia proposta, o que facilitou no fracionamento do substrato e na análise do material residual presente nos produtos finais por meio dos fluxos de massas obtidos. A metodologia proposta pode ser uma ferramenta de ajuda para a padronização da modelação matemática de processos biológicos de tratamento.

Gernaey et al. (2006) ressaltaram que devem ser realizadas extensivas codificações para tornar independente a implementação de modelos de simulações de processos que envolvam o meio ambiente. Os autores destacaram estudos recentes que demonstram a dificuldade de obter modelos sem erros, como por exemplo, digitação dos códigos, escolha da DQO como base para diversos processos no modelo, aproximações de parâmetros estequiométricos e ainda dificuldade de troca entre os diversos simuladores Aquasim 2.0, Matlab, GPS-X, SIMBA e WEST.

Os autores propuseram a plataforma independente SBML para padronizar a codificação dos modelos, implementando o modelo de maneira mais eficiente devido a redução do tempo de trabalho.

O modelo ADM1 tem sido aplicado para ilustrar o processo de digestão de lodos de esgoto (COPP et al., 2005, SOTEMANN et al., 2005, SHANG et al., 2005 e PICIOREANU et al., 2005) e de tratamento de esgotos industriais (BATSTONE e KELLER, 2003).

De modo geral é possível concluir que os modelos matemáticos apresentam limitações quanto à aplicação em casos generalizados, pois são em sua maioria específicos para um determinado tipo de tratamento, de substrato e de microrganismos, exigindo conhecimento significativo dos processos envolvidos e definição das variáveis de entrada a serem determinadas experimentalmente. Por outro lado, os modelos matemáticos auxiliam no dimensionamento e na avaliação do comportamento de sistemas de tratamento. 


\section{MATERIAL E MÉTODOS}

Esse capítulo descreve a metodologia aplicada no desenvolvimento do projeto de doutorado para realização dos objetivos propostos. A metodologia foi dividida em duas partes: experimental e teórica. A parte experimental compreendeu as etapas de projeto, confecção, montagem, instalação e operação de reator UASB, em escala piloto, e de seu sistema de alimentação, realização de ensaios experimentais e de exames microbiológicos. A parte teórica compreendeu as etapas de análise e preparação dos resultados experimentais obtidos e de sua aplicação como variáveis (dados) de entrada para a calibração dos modelos MMS e ADM1 e validação do modelo MMS.

\subsection{PARTE EXPERIMENTAL}

A parte experimental da pesquisa foi dividida em quatro etapas: A primeira etapa compreendeu a partida e operação do reator UASB de 146 L com cargas hidráulica e orgânica constantes com vazão média afluente de 18,2 L.h ${ }^{-1}$ e tempo de detenção hidráulica igual a $8 \mathrm{~h}$. Nessa etapa, os resultados das análises de monitoramento possibilitaram constatar arraste de sólidos e aumento da DQO no efluente do reator, com conseqüente queda na eficiência de remoção de DQO do sistema. Uma das possíveis explicações para o arraste de sólidos na saída do reator seria o aumento da velocidade ascensional de fluxo, causada pelo estrangulamento da parte superior do separador de fases. Para minimizar esse arraste optou-se por instalar um separador de fases com maior abertura para a passagem do efluente.

A segunda etapa correspondeu à operação e monitoramento do reator UASB com o novo separador de fases, volume total de $160 \mathrm{~L}$, tempo de detenção hidráulica de 10 h e vazão média afluente de $16,0 \mathrm{~L} \cdot \mathrm{h}^{-1}$. 
A terceira e quarta etapas corresponderam à operação e monitoramento do reator UASB submetido a variações cíclicas diárias de cargas orgânica e hidráulica em valores inferiores e superiores a $40 \%$ e $60 \%$, respectivamente.

Em todas as etapas de operação foram realizados ensaios experimentais para monitorar o comportamento do reator no tratamento de águas residuárias, exames microbiológicos da biomassa, ensaios hidrodinâmicos e análises dos resultados obtidos.

Os resultados experimentais obtidos com a realização das análises serviram como base para comparação com os resultados das outras etapas.

\subsubsection{ETAPA I}

\subsubsection{REATOR UASB EM ESCALA PILOTO (146 L)}

A confecção e a montagem do reator UASB em escala piloto foram realizadas na oficina mecânica da Universidade de São Paulo (área I) em São Carlos (EESC/USP).

O reator UASB foi instalado no Laboratório de Tratamento de Resíduos (LTR) da Universidade de São Paulo (área I) em São Carlos (EESC/USP).

O reator UASB com capacidade de 146 L era constituído de uma coluna cilíndrica em PVC com diâmetro de 0,30 m e altura de 1,86 m, e de um separador trifásico (gás-sólido-líquido) em aço inox, com altura total de 0,34 m. O separador de fases estava acoplado à coluna cilíndrica à distância de $1,86 \mathrm{~m}$ da base do reator (Figura 1.a). O reator possuía seis pontos de amostragem, espaçados de $19 \mathrm{~cm}$ (pontos 1 e 2) e $37 \mathrm{~cm}$ (pontos 3, 4, 5 e 6), ao longo da altura do reator.

O sistema de coleta de gás era composto por mangueira de silicone acoplada a saída de gás do reator, selo hídrico em PVC e medidor de vazão de biogás produzido. A mangueira de silicone ligava a saída de gás do reator ao selo hídrico, que foi conectado ao medidor por mangueira de silicone (Figura 1.b). 

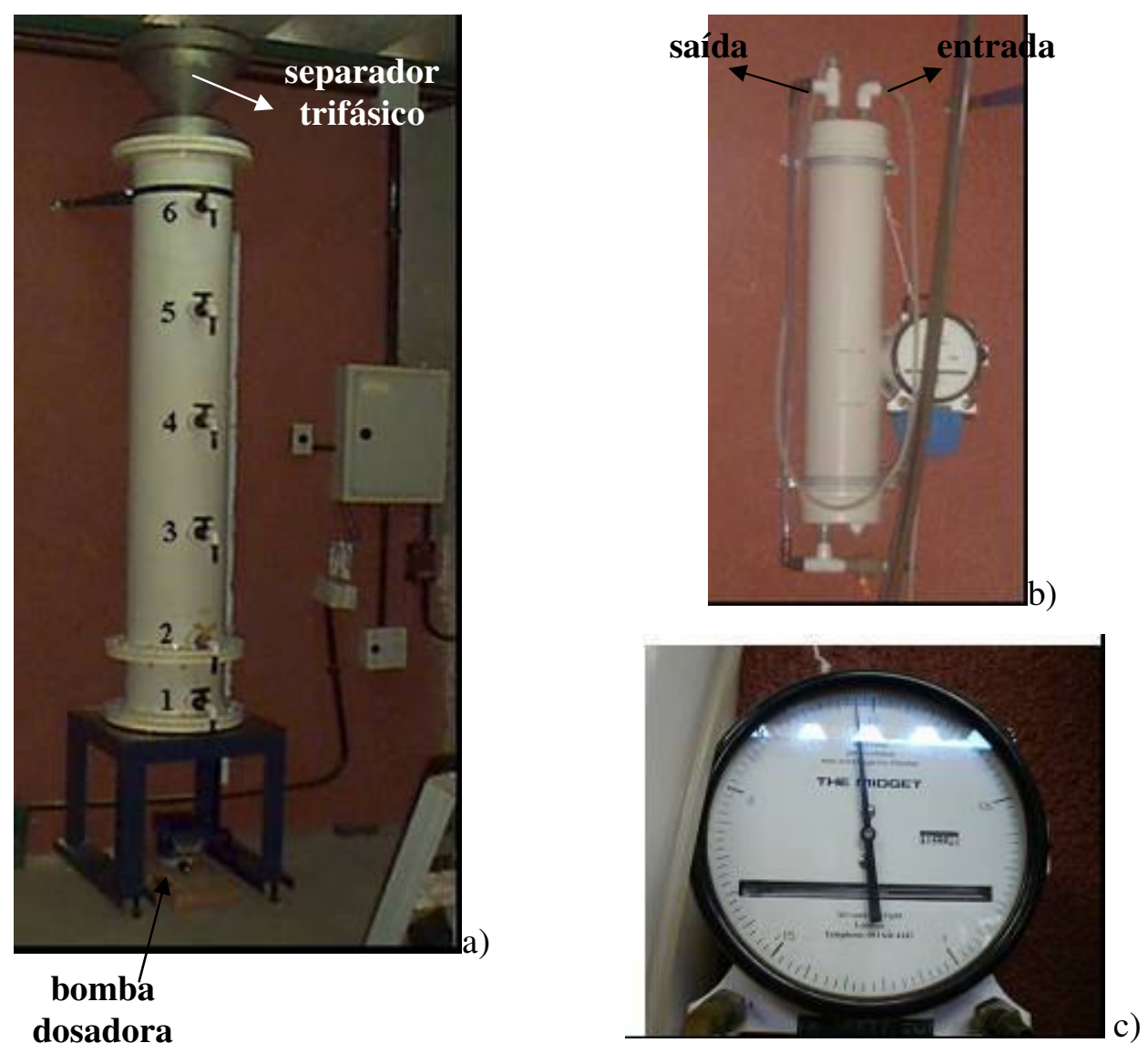

Figura 1. a) Reator UASB e pontos de coleta de amostras. b) Sistema de coleta de gás. c) Medidor de biogás.

O selo hídrico confeccionado em PVC com 0,05 m de diâmetro e 0,80 m de altura foi projetado para manter a pressão de gás a 0,26 mca nas calhas de coleta do reator e manter uma superfície de separação das fases gás/líquido e gás/sólido dentro do sistema de coleta de gás. Uma solução de hidróxido de sódio $(\mathrm{NaOH})$ com concentração de 5 molar foi colocada no interior do sistema de coleta de gás para medir apenas a vazão do gás metano. O medidor de biogás com contador de giro da marca The Midget (Figura 1.c) utilizado no experimento indicava a vazão diária de biogás produzida.

O esgoto sanitário coletado para alimentar o reator foi armazenado em dois tanques de equalização em série, com capacidades de 350 L e 240 L, respectivamente. Esses tanques possibilitaram o armazenamento do esgoto bruto proveniente do sistema de recalque em períodos de $24 \mathrm{~h}$, sua suplementação e a possibilidade de manutenção da qualidade do substrato para controle das condições de entrada do reator (Figura 2). 


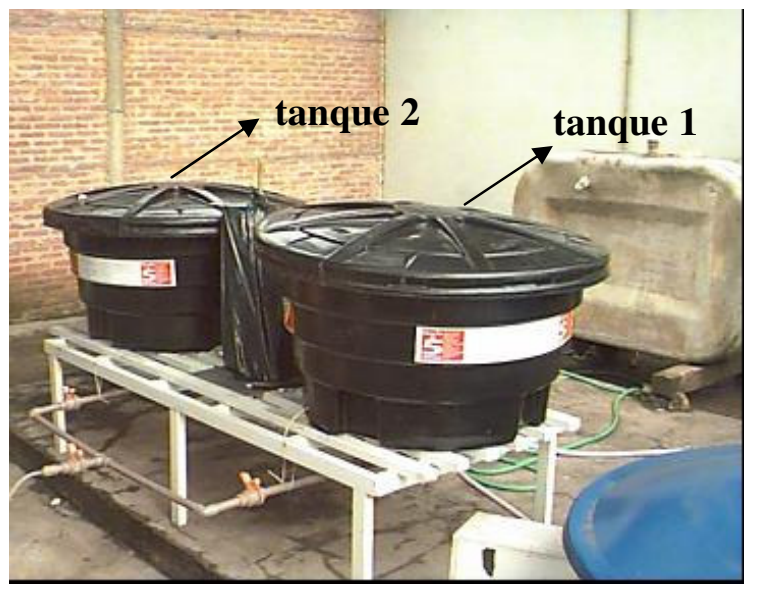

Figura 2. Tanques de armazenamento

Partindo do segundo tanque de armazenamento, o substrato foi introduzido no reator por meio de bomba dosadora eletromagnética (série BLA/5), automatizada, da marca Blowair, dotada de amortecedor de pulso na linha de alimentação, para diminuir os eventuais distúrbios causados pela pulsação.

\subsubsection{ETAPA II}

\subsubsection{REATOR UASB EM ESCALA PILOTO (160 L)}

O novo separador de fases gás-sólido-líquido foi confeccionado em PVC, com 0,60 m de altura e 0,30 m de diâmetro. Com a instalação do novo separador de fases, o volume do reator UASB passou a ser de $160 \mathrm{~L}$ (Figura 3).

Com a maior abertura do separador de fases para passagem do efluente, houve diminuição da velocidade ascensional do líquido, que contribuiria para evitar o arraste de sólidos e conseqüentemente a queda de eficiência do sistema. 


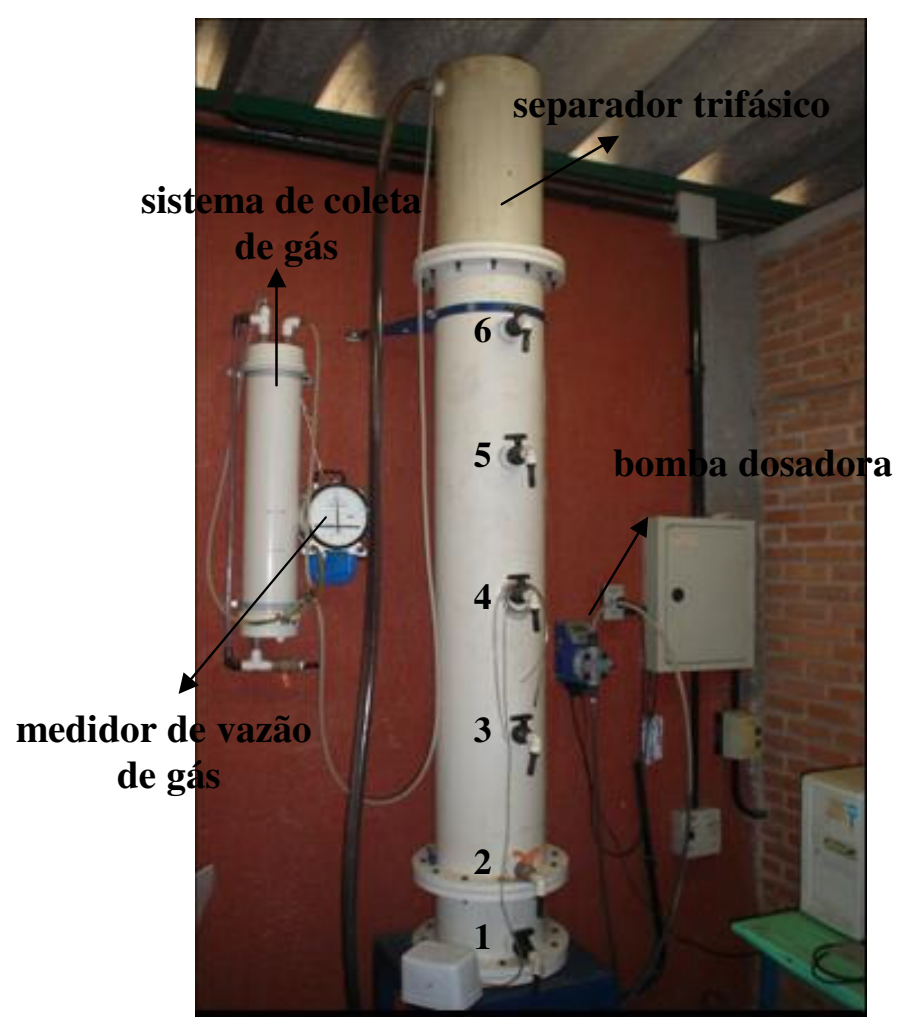

Figura 3. Reator UASB com novo separador de fases

\subsubsection{SUBSTRATO}

O substrato utilizado na alimentação do reator UASB foi composto de esgoto sanitário coletado na estação elevatória do Laboratório de Tratamento de Resíduos (LTR) suplementado com esgoto sintético simulando esgoto real.

O esgoto bruto utilizado na alimentação do reator era proveniente de um bairro de classe média e zona comercial da cidade de São Carlos, com muitos habitantes por metro quadrado e elevado consumo de água per capita, o que provavelmente contribuiu para sua diluição. Esse esgoto sanitário caracterizava-se pela baixa concentração de matéria orgânica afluente, variável na faixa de $140 \mathrm{mg} . \mathrm{L}^{-1}$ a $400 \mathrm{mg} . \mathrm{L}^{-1}$ (em termos de DQO), o que justificou a necessidade de suplementação com esgoto sintético. Assim, a suplementação do esgoto bruto com esgoto sintético, simulando esgoto real, foi realizada para elevar a DQO afluente para a faixa de $450 \mathrm{mg} . \mathrm{L}^{-1}$ a $700 \mathrm{mg} \cdot \mathrm{L}^{-1}$. 
O controle da concentração de matéria orgânica afluente em faixa conhecida era de suma importância para que a avaliação do comportamento do reator UASB ao longo do experimento não fosse prejudicada.

A composição do esgoto sintético suplementar utilizado baseou-se na composição reportada por Torres (1992), para valor médio de DQO de aproximadamente $300 \mathrm{mg} \cdot \mathrm{L}^{-1}$. Essa composição é apresentada na Tabela 3.

Tabela 3. Composição do esgoto sintético para DQO média igual a 300mg. $\mathrm{L}^{-1}$

\begin{tabular}{ccc}
\hline Componente & Concentração $\left(\mathrm{mg}^{-\mathrm{L}^{-1}}\right)$ & DQO $\left(\mathrm{mg.L}^{-1}\right)$ \\
\hline carboidratos & 22,82 & 26,0 \\
Sacarose & 70,63 & 74,35 \\
Amido de milho & & \\
$\quad$ lipídeos & 32,6 & 31,96 \\
Óleo de soja & 11 gotas. $\mathrm{L}^{-1}(240 \mathrm{~L})$ & 5,0 \\
Detergente para emulsão & 25 gotas. $\mathrm{L}^{-1}(350 \mathrm{~L})$ & \\
proteínas & & 162,52 \\
Extrato de carne & 271,74 &
\end{tabular}

Fonte: adaptado de Torres (1992)

A preparação do esgoto sintético concentrado consistiu de pesagem dos componentes; cozimento do amido com $300 \mathrm{~mL}$ de água de torneira em forno de microondas por aproximadamente $1 \frac{1}{2} 2 \mathrm{~min}$; mistura de todos os componentes; diluição da mistura em $700 \mathrm{~mL}$ de água de torneira e pelo lançamento nos tanques de armazenamento.

Análises de DQO foram realizadas para adaptar a concentração de matéria orgânica afluente desejada àquela reportada por Torres (1992) de aproximadamente $300 \mathrm{mgDQO} . \mathrm{L}^{-1}$, sempre mantendo a proporcionalidade de cada componente do esgoto sintético.

A estabilidade do substrato (esgoto bruto + esgoto sintético) armazenado nos tanques de equalização foi analisada por análises de DQO realizadas durante período de 5 dias. 
As determinações das concentrações dos parâmetros de controle: DQO (bruta e filtrada), ácidos voláteis, alcalinidades total e a bicarbonato, sólidos totais e suspensos e $\mathrm{pH}$ foram realizadas para caracterizar o substrato. A metodologia utilizada para a realização dessas análises encontra-se descrita no item 4.1.5 - Operação e Monitoramento do reator UASB do capítulo Material e Métodos.

\subsubsection{INÓCULO}

O reator foi inoculado com lodo anaeróbio granular, proveniente de reator anaeróbio que trata água residuária de abatedouro de aves (Avícola Dacar), situado no município de Tietê, no estado de São Paulo.

A escolha do lodo foi justificada por sua utilização em diversas pesquisas no Laboratório de Processos Biológicos (área I) da Universidade de São Paulo em São Carlos (EESC/USP), devido principalmente à grande diversidade microbiana apresentada (HIRASAWA, 2003).

Utilizou-se $55 \mathrm{~L}$ de lodo para inoculação, correspondente a aproximadamente $34 \%$ do volume total do reator (Figura 4).

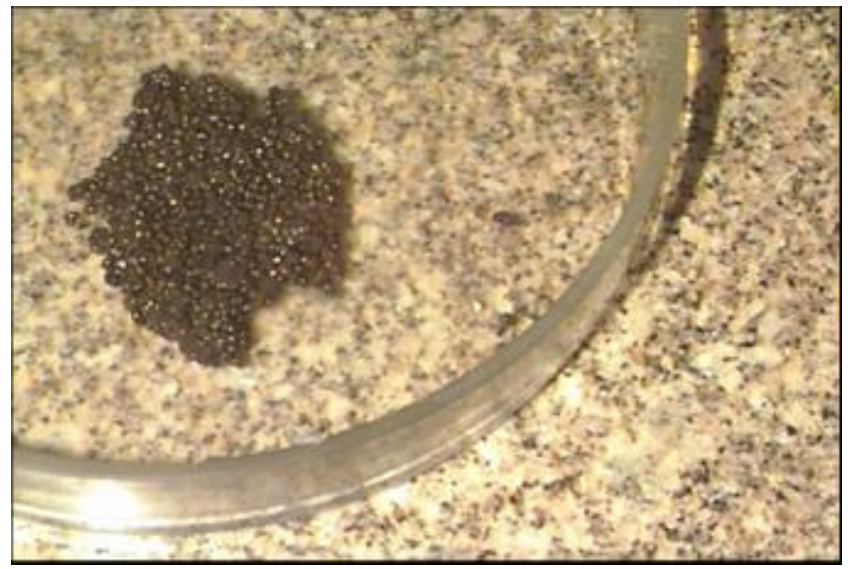

\section{Figura 4. Lodo anaeróbio granular utilizado como inóculo}

Exames microscópicos e determinações das concentrações de sólidos totais e voláteis foram realizados durante todo o período de operação do reator para avaliar o comportamento do manto de lodo e da microbiota ao longo da altura do reator. 
O procedimento adotado na coleta e no preparo das amostras para realização dos exames microscópicos está descrito no item 4.1.6 - Exames Microbiológicos do capítulo Material e Métodos.

As determinações de sólidos totais, sólidos totais voláteis e de sólidos totais fixos foram realizadas com amostras líquidas de $100 \mathrm{~mL}$ nos seis pontos de amostragem ao longo da altura do reator. As metodologias para determinação das concentrações de sólidos foram realizadas de acordo com Standard Methods for the Examination of Water and Wastewater (1998).

\subsubsection{OPERAÇÃO E MONITORAMENTO DO REATOR UASB}

\subsubsection{OPERAÇÃO DO REATOR UASB}

A operação, bem como o monitoramento do reator UASB, foi dividida em quatro etapas para facilitar a apresentação e compreensão dos resultados.

A Tabela 4 apresenta um resumo das etapas de operação do reator UASB.

Tabela 4. Etapas de operação do reator UASB

\begin{tabular}{cccccc}
\hline etapa & $\begin{array}{c}\text { período de } \\
\text { operação }\end{array}$ & Q & TDH & $\begin{array}{c}\text { velocidade } \\
\text { ascensional }\end{array}$ & $\begin{array}{c}\mathrm{n}^{\circ} \text { de perfis } \\
\text { de } \\
\text { amostragem } \\
\text { temporal }\end{array}$ \\
\hline inicial & 0 a 1 & batelada & - & - & - \\
\hline I & 2 a 13 & 12,1 & 12 & 0,17 & 2 \\
\cline { 2 - 5 } & 14 a 291 & 18,2 & 8 & 0,26 & 2 \\
\hline II & 292 a 309 & 16,0 & 10 & 0,23 & 2 \\
\hline III & 310 a 344 & mín $=14,5$ & 11 & 0,21 & 2 \\
\hline \multirow{2}{*}{ IV } & 345 a 372 & máx $=17,5$ & 9 & 0,25 & 2 \\
\hline
\end{tabular}


ETAPA INICIAL - Inoculação e partida do reator UASB. Após a inoculação, o reator UASB (146 L) foi alimentado com esgoto bruto, por um período de $24 \mathrm{~h}$, em regime de batelada.

ETAPA I - Essa etapa teve início com a operação do reator em regime de fluxo contínuo, com vazão média afluente de aproximadamente $12,1{\mathrm{~L} . \mathrm{h}^{-1}}^{-1}$, velocidade ascensional de $0,17 \mathrm{~m} \cdot \mathrm{h}^{-1}$ e tempo de detenção hidráulica de $12 \mathrm{~h}$ por um período de dez dias. Nesse período, o reator foi alimentado apenas com esgoto bruto. A partir do $14^{\circ}$ dia de operação, o reator foi operado com vazão média afluente de aproximadamente 18,2 L.h ${ }^{-1}$, velocidade ascensional de $0,26 \mathrm{~m} \cdot \mathrm{h}^{-1}$ e tempo de detenção hidráulica de $8 \mathrm{~h}$ e alimentado com esgoto bruto suplementado com esgoto sintético, até atingir o estado de equilíbrio dinâmico aparente, no $90^{\circ}$ dia de operação. Os perfis de amostragem temporal foram realizados no $181^{\circ}$ dia e no $189^{\circ}$ dia de operação.

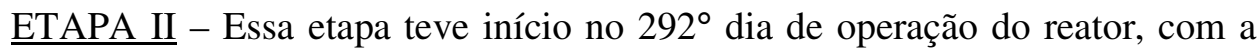
substituição do separador de fases. Essa modificação foi acompanhada de alterações das condições operacionais do reator: vazão média afluente de aproximadamente 16,0 L.h ${ }^{-1}$, velocidade ascensional de $0,23 \mathrm{~m} \cdot \mathrm{h}^{-1}$ e tempo de detenção hidráulica de 10 h. Após o alcance do estado de equilíbrio dinâmico aparente no $303^{\circ}$ dia, o reator foi avaliado por dois perfis de amostragem temporal efetuados no $304^{\circ}$ dia e no $309^{\circ}$ dia de operação.

ETAPA III - A etapa III teve início no $310^{\circ}$ dia de operação do reator, com aplicação de variação senoidal cíclica da carga hidráulica em valores inferiores e superiores a 40\%, da vazão média afluente de 16,0 L.h ${ }^{-1}$. As variações impostas nessa etapa foram acompanhadas com conseqüente variação de carga orgânica, visto que o esgoto afluente era mantido em tanques de equalização. Nessa etapa também foram realizados dois perfis de amostragens temporais, no $320^{\circ}$ e no $344^{\circ}$ dia, após o reator ter alcançado o estado de equilíbrio dinâmico aparente no $319^{\circ}$ dia de operação.

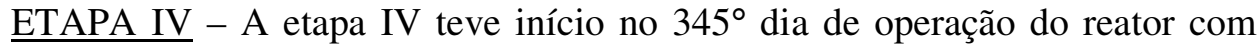
aplicação da variação senoidal cíclica da carga hidráulica em valores inferiores e superiores a $60 \%$ da vazão média afluente de $16,0 \mathrm{~L} \cdot \mathrm{h}^{-1}$. Nessa etapa também foram realizados dois perfis de amostragens temporais no $349^{\circ}$ e no $370^{\circ}$ dia de operação após o reator ter alcançado o estado de equilíbrio dinâmico aparente (348 dia). 
Como pode ser observado na Tabela 4, a vazão afluente aplicada ao reator UASB submetido a variações cíclicas senoidais de amplitude de $40 \%$ alcançou picos de mínimo e de máximo iguais a 14,5 L.h ${ }^{-1}$ e 17,5 L.h ${ }^{-1}$, respectivamente, na etapa III. $\mathrm{Na}$ etapa IV, a vazão afluente alcançou picos de mínimo e de máximo iguais a 13,7 L.h ${ }^{-1}$ e 18,3 L.h ${ }^{-1}$, respectivamente, com aplicação das variações cíclicas de carga hidráulica de $60 \%$.

A aplicação da variação senoidal de vazão foi realizada por programa computacional que alterava percentualmente a vazão média afluente em intervalos de 15 min, em período total de $24 \mathrm{~h}$. A Figura 5 apresenta as variações senoidais de $40 \%$ e $60 \%$ da vazão média afluente de $16,0 \mathrm{~L} \cdot \mathrm{h}^{-1}$.

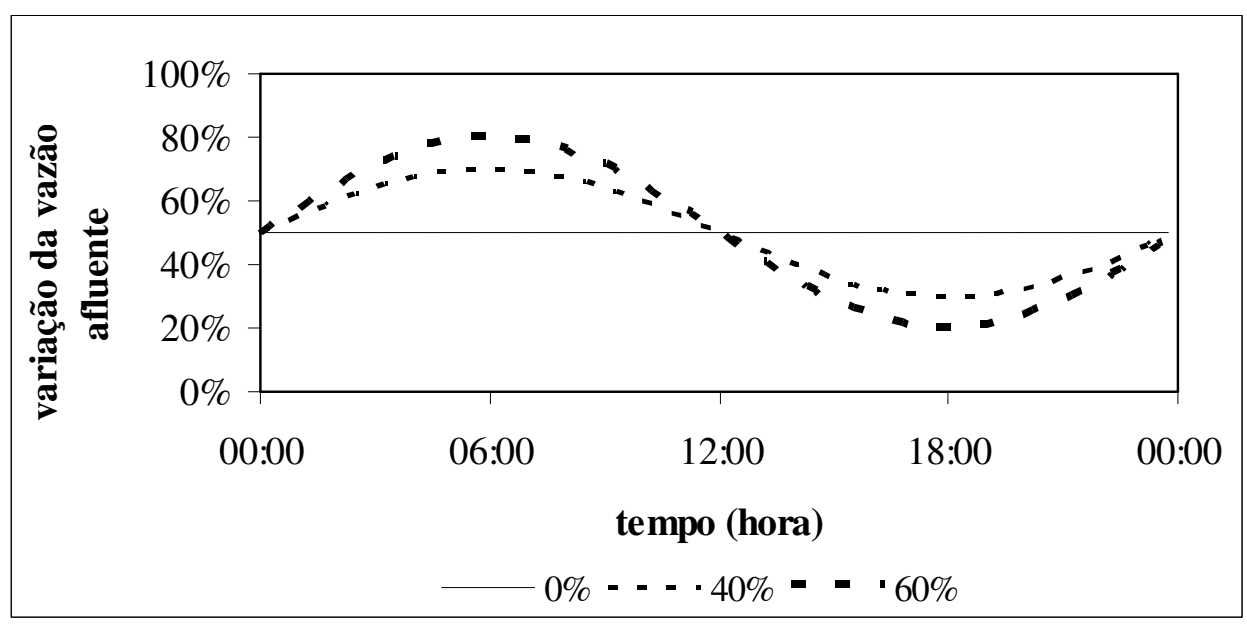

Figura 5. Variações senoidais da vazão média afluente com amplitudes de $40 \%$ e de $60 \%$

\subsubsection{MONITORAMENTO DO REATOR}

Todas as análises físico-químicas realizadas nesse trabalho foram feitas no Laboratório de Processos Biológicos (LPB) da Universidade de São Paulo (área I) em São Carlos (EESC/USP).

Nas etapas I, II, III e IV, o comportamento do reator foi avaliado por determinações dos parâmetros de controle em amostras do afluente (substrato) e do efluente (Tabela 5): DQO (bruta e filtrada), pH, alcalinidade total e a bicarbonato, ácidos voláteis, sólidos suspensos fixos (SST), sólidos suspensos voláteis (SSV), 
sólidos totais fixos (STF) e sólidos totais voláteis (STV). A Tabela 6 apresenta a freqüência adotada para a realização das análises de monitoramento do reator. A mesma frequiência para realização das análises foi adotada em todas as etapas de operação.

Em cada etapa de operação após o reator ter alcançado o estado de equilíbrio dinâmico aparente foram realizados dois perfis de amostragem temporal, com intervalos de $3 \mathrm{~h}$ entre as coletas em período de $24 \mathrm{~h}$. O alcance do estado de equilíbrio dinâmico aparente foi verificado por meio dos mesmos parâmetros determinados no monitoramento do reator.

Nos perfis de amostragem temporal, além da determinação dos parâmetros de controle do monitoramento, foram determinadas DBO e concentrações de nitrogênio total (N-NTK), nitrogênio amoniacal $\left(\mathrm{N}-\mathrm{NH} 4^{+}\right)$e carboidratos com coleta de amostras compostas de mesma alíquota para o afluente e efluente do reator.

Nas etapas III e IV, as coletas das amostras para realização dos perfis de amostragens temporais foram realizadas no primeiro dia da aplicação da nova amplitude. Os resultados obtidos nessas etapas possibilitaram a avaliação do comportamento do reator quando submetido a variações de carga orgânica ou hidráulica e a comparação com os resultados experimentais obtidos nas etapas anteriores.

Os parâmetros analisados no substrato, efluente, pontos intermediários e inóculo, seus respectivos métodos e bibliografia utilizada são apresentados na Tabela 5.

Além da aplicação do método titulométrico para determinação da concentração total de ácidos descrito por Dillalo e Albertson (1961), foi empregado o método de cromatografia gasosa com utilização do cromatógrafo HP 6890 para identificação da composição individual de cada ácido.

A composição do biogás em termos de porcentagem dos gases metano, gás carbônico, nitrogênio e oxigênio gerados pelo sistema foi avaliada por cromatografia gasosa utilizando cromatógrafo Gow-Mac. O cromatógrafo tem coluna empacotada com Porapak Q (partículas de 80 a 100 mesh) com comprimento de 2 m e diâmetro interno de $1 / 4$ " e detector de condutividade térmica. 
Tabela 5. Parâmetros analisados, seus respectivos métodos e metodologia utilizada

\begin{tabular}{|c|c|c|c|}
\hline Parâmetros & Método de Análise & Método $\mathrm{N}^{\circ}$ & Referência \\
\hline $\begin{array}{l}\text { Temperatura } \\
\text { pH }\end{array}$ & $\begin{array}{c}- \\
\text { Potenciométrico }\end{array}$ & 4500_ $\mathrm{H}^{+}$ & APHA, 1998 \\
\hline Alcalinidade & Titulométrico & - & $\begin{array}{c}\text { Dillalo e Albertson (1961) } \\
\text { modificado por Ripley et } \\
\text { al. }(1986)\end{array}$ \\
\hline DQO & Espectrofotométrico & 5220_D & APHA (1998) \\
\hline DBO & Titulométrico & 5210_D & APHA (1998) \\
\hline $\begin{array}{l}\text { Sólidos } \\
\text { suspensos }\end{array}$ & Gravimétrico & 2540_G & APHA (1998) \\
\hline $\begin{array}{l}\text { Sólidos } \\
\text { totais }\end{array}$ & Gravimétrico & 2540_E & APHA (1998) \\
\hline $\begin{array}{l}\text { Ácidos } \\
\text { voláteis }\end{array}$ & $\begin{array}{l}\text { Titulométrico } \\
\text { (concentração) }\end{array}$ & - & Dillalo e Albertson (1961) \\
\hline & $\begin{array}{l}\text { Cromatografia Gasosa } \\
\text { (composição) }\end{array}$ & - & - \\
\hline N-NTK & Titulométrico & 4500_N $\mathrm{NRG}_{\text {OR }}$ & APHA (1998) \\
\hline $\mathrm{N}-\mathrm{NH}_{4}{ }^{+}$ & Titulométrico & 4500_ $\mathrm{NO}_{3}^{-}$ & APHA (1998) \\
\hline Gases & Cromatografia gasosa & - & - \\
\hline Carboidratos & Espectrofotométrico & - & Blundi e Gadelha (2001) \\
\hline
\end{tabular}

Os parâmetros para monitoramento do reator durante o período de partida, bem como suas respectivas freqüências de análises, são apresentados na Tabela 6 .

Tabela 6. Parâmetros analisados e suas freqüências (partida do reator)

\begin{tabular}{|c|c|c|c|c|}
\hline \multirow[t]{2}{*}{ Parâmetro } & \multirow[b]{2}{*}{ unidade } & \multicolumn{3}{|c|}{ Freqüência de amostragem } \\
\hline & & afluente & reator & efluente \\
\hline composição de biogás & $\% \mathrm{CH} 4$ & - & semanal & - \\
\hline temperatura & ${ }^{\circ} \mathrm{C}$ & diária & diária & diária \\
\hline $\mathrm{pH}$ & - & diária & diária & diária \\
\hline alcalinidade a bicarbonato & $\mathrm{mg} \cdot \mathrm{L}^{-1}$ & $3 \mathrm{x}$ semana & - & $3 \mathrm{x}$ semana \\
\hline alcalinidade total & $\mathrm{mg} \cdot \mathrm{L}^{-1}$ & $3 \mathrm{x}$ semana & - & $3 \mathrm{x}$ semana \\
\hline ácidos voláteis & $\mathrm{mg} \cdot \mathrm{L}^{-1}$ & $3 \mathrm{x}$ semana & - & $3 \mathrm{x}$ semana \\
\hline sólidos suspensos e totais - fixos/voláteis & $\mathrm{mg} . \mathrm{L}^{-1}$ & $3 \mathrm{x}$ semana & - & $3 \mathrm{x}$ semana \\
\hline DQO (bruta e filtrada) & mg. $L^{-1}$ & $3 \mathrm{x}$ semana & - & $3 \mathrm{x}$ semana \\
\hline
\end{tabular}


As amostras de biogás foram coletadas em seringas plásticas $(50 \mathrm{~mL})$ diretamente da mangueira de silicone da saída de gás do reator e 0,5 mL foram injetados no cromatógrafo. O procedimento de coleta e injeção das amostras de biogás foi realizado em triplicata.

Após atingir o estado estacionário em cada etapa de operação, o sistema foi monitorado duas vezes por semana por meio dos mesmos parâmetros apresentados na Tabela 6.

Os resultados experimentais obtidos em todas as fases ao longo da operação do reator foram empregados para demonstração do comportamento do sistema, por meio de gráficos e equações empíricas de correlação e foram utilizados na calibração dos modelos matemáticos.

\subsubsection{EXAMES MICROBIOLÓGICOS}

Os exames microbiológicos do inóculo e das amostras de lodo coletadas do reator UASB foram realizados por microscopia ótica comum, de fluorescência e de contraste de fase com microscópio Leica DM LB (ob 100x), sistema de câmera digital Leica DC 200 e programa computacional Image Pro-Plus na versão 4.5.0. Esse programa foi utilizado para aquisição e armazenamento das imagens dos tipos morfológicos observados com o microscópio e câmera digital no Laboratório de Processos Biológicos da Universidade de São Paulo (área I) em São Carlos.

As amostras de lodo do reator UASB foram coletadas nos seis pontos de amostragem ao longo da altura do reator, após o sistema atingir o estado de equilíbrio dinâmico aparente em cada etapa de operação, a fim de que pudesse ser avaliada a microbiota presente no sistema.

As amostras foram colocadas em frascos contendo pérolas de vidro os quais sofreram agitação para promover quebra dos grânulos existentes nessas amostras. Com a ruptura dos grânulos, as amostras líquidas foram colocadas em lâminas de vidro com ágar para observação no microscópio. 


\subsubsection{ENSAIOS DE ATIVIDADE METANOGÊNICA}

Os ensaios de atividade metanogênica foram realizados com o objetivo de avaliar a influência das variações senoidais da vazão no comportamento das populações microbianas ao longo da operação do reator.

As amostras de lodo do reator UASB foram submetidas a ensaios de atividade metanogênica específica (AME), com base na metodologia descrita por Steil et al. (2004), adaptada de Dubourguier (1989) ${ }^{4}$ apud Vazoller (1989) e Chernicharo (1997).

As amostras da manta de lodo foram coletadas no $308^{\circ}$ dia (etapa II), $343^{\circ}$ dia (etapa III) e $369^{\circ}$ dia (etapa IV), após o reator ter alcançado o estado de equilíbrio dinâmico aparente em cada etapa de operação.

O ensaio de AME consistiu na determinação periódica por cromatografia gasosa da concentração de metano presente no biogás produzido no volume livre de frascos-reatores após a adição de mistura dos ácidos acético, propiônico, butírico e fórmico na relação 2:1:1:1. A mistura desses ácidos foi escolhida porque corresponde aos principais produtos intermediários gerados no processo de digestão anaeróbia de esgotos domésticos. Paralelamente buscou-se disponibilizar todos os substratos comumente presentes na metanogênese e assim possibilitar a determinação da AME total.

O ensaio foi dividido em duas etapas: Na primeira etapa a amostra proveniente do ponto de coleta n. 2 foi testada para três relações substrato/microrganismo: 0,25 ; 0,50 e 0,75 gDQO. $\mathrm{g}^{-1} \mathrm{SV}$ (inicial) a fim de se determinar a melhor relação para esse tipo de amostra. Na segunda etapa, amostras de três pontos de amostragem do reator (Figura 27) foram coletadas durante a aplicação das variações cíclicas de vazão de $40 \%$ e de $60 \%$ após o reator ter atingido o estado de equilíbrio dinâmico aparente. Posteriormente as amostras foram submetidas ao ensaio, mantendo-se a relação inicial de substrato/microrganismo de 0,25 gDQO.g ${ }^{-1} \mathrm{SV}$.

Os frascos-reatores com as amostras foram mantidos nas condições do ensaio de AME até que a produção de metano se estabilizasse antes da adição do substrato

${ }^{4}$ DUBOURGUIER H.C., PRENSIER, G., SAMAIN, E. e ALBAGNAC, G. (1989). Granular Methanogenic Sludge: Microbial and Structural Analysis. In: $3^{\text {th }}$ INTERNATIONAL CONFERENCE ON BIOMASS, Venice, Italy, Proceedings. p. 542-546. 
para que a matéria orgânica remanescente da própria amostra fosse consumida e não interferisse nos resultados finais de AME.

A concentração de sólidos voláteis (SV) das amostras foi determinada nesse momento e o valor obtido foi utilizado para calcular a quantidade de substrato a ser adicionada e a atividade metanogênica específica $\left(\mathrm{mmolCH}_{4} \cdot \mathrm{g}^{-1} \mathrm{SV} \cdot \mathrm{d}^{-1}\right)$ ao final do ensaio. Os ensaios foram conduzidos em triplicata e frascos-reatores sem adição de substrato serviram como controle.

\subsubsection{ANÁLISE DA COMUNIDADE MICROBIANA}

A análise da comunidade microbiana foi realizada para estudar a diversidade de microrganismos presente no reator submetido a diferentes condições operacionais.

As amostras para realização dos exames foram coletadas dos mesmos pontos utilizados para os ensaios de atividade metanogênica (Figura 27).

A estrutura da comunidade microbiana foi avaliada por meio de técnica de eletroforese em gel com gradiente desnaturante (DGGE), de acordo com metodologia descrita em Brucha (2002), em conjunto com a M.Sc. Lara Steil no Laboratório de Processos Biológicos da Universidade de São Paulo (área I) em São Carlos (EESC/USP).

A técnica do PCR (Polymerase Chain Reaction) consiste na extração e amplificação de ácidos nucléicos de amostras de células cultivadas ou não-cultivadas. Após os processos de extração e amplificação, os fragmentos de DNA de mesmo comprimento e sequiência diferente, são separados pela técnica do DGGE (Denaturing Gradient Gel Eletrophoresis).

No presente trabalho, o DNA total foi extraído das amostras e os DNAr 16S foram amplificados por PCR com utilização de primers universais para os Domínios Archaea e Bacteria. Os produtos de PCR foram então separados por DGGE, com decréscimo da mobilidade eletroforética da dupla hélice da molécula de DNA. A molécula de DNA permanece parcialmente fundida no gel de poliacrilamida, que contém gradiente linear desnaturante (mistura de uréia e formamida) (MUYZER et al., 1993). Os primers usados para o Domínio Bacteria foram descritos por Nielsen et al. (1999) e os do Domínio Archaea por Kudo et al. (1997). 


\subsubsection{ENSAIOS HIDRODINÂMICOS}

Para avaliar a influência das variações senoidais cíclicas de $40 \%$ e de $60 \%$ da vazão afluente no comportamento do reator UASB, foram realizados levantamentos da resposta hidrodinâmica nas três condições operacionais utilizadas (etapas II, III e IV). Os resultados experimentais obtidos foram comparados aos modelos matemáticos de uso corrente na literatura para avaliação hidrodinâmica de reatores.

Dois perfis hidrodinâmicos tipo pulso foram realizados em cada etapa de operação do reator com volume de 160 L. Os ensaios hidrodinâmicos da primeira etapa foram realizados com aplicação de vazão média afluente constante e igual a $16,0 \mathrm{~L} \cdot \mathrm{h}^{-1}$ e tempo de detenção hidráulica médio constante e igual a $10 \mathrm{~h}$. Os ensaios hidrodinâmicos da segunda etapa foram realizados com aplicação de variação cíclica senoidal de $40 \%$ da vazão média afluente. Na terceira etapa, o ensaio hidrodinâmico foi realizado com aplicação de variação cíclica senoidal de $60 \%$ da vazão média afluente. Os procedimentos adotados para realização dos ensaios de estímulo-resposta tipo pulso foram divididos em três etapas (Tabela 7).

$\mathrm{O}$ reator foi alimentado continuamente com esgoto doméstico com concentração de matéria orgânica variando na faixa de $470 \mathrm{mg} . \mathrm{L}^{-1}$ a $800 \mathrm{mg} . \mathrm{L}^{-1}$ (em termos de DQO) em todas as etapas dos ensaios de estímulo-resposta e mantido à temperatura ambiente.

Todos os ensaios foram realizados com o corante Eosina Y como traçador, após o reator UASB ter alcançado o estado de equilíbrio dinâmico aparente em cada etapa. O método colorimétrico de leitura de absorbância foi aplicado para determinação da concentração de eosina Y nas amostras do efluente do reator. As leituras dos comprimentos de ondas foram realizadas em espectrofotômetro Hach uv-vis, modelo DR/2000, com comprimento de onda $(\lambda)$ de $516 \mathrm{~nm}$.

As condições operacionais do reator, a concentração e a massa molecular do traçador são apresentadas na Tabela 7. O volume de injeção do traçador foi de aproximadamente $20 \mathrm{~mL}$ em cada ensaio e o tempo de injeção foi de aproximadamente $50 \mathrm{~s}$.

O tempo total de duração dos ensaios foi determinado de tal forma que as

amostras fossem coletadas pelo menos durante três vezes o tempo de detenção 
hidráulico teórico, com intervalos não superiores a uma hora. As amostras coletadas foram centrifugadas por cerca de 4 minutos para evitar a interferência da presença de sólidos na leitura das absorbâncias pelo método espectrofotométrico.

Tabela 7. Características dos ensaios de estímulo-resposta realizados no reator UASB

\begin{tabular}{|c|c|c|c|c|c|c|}
\hline Etapas & Ensaios & $\begin{array}{l}\theta \mathrm{h} \\
(\mathrm{h})\end{array}$ & $\begin{array}{c}\text { Vazão } \\
\text { afluente } \\
\text { aplicada } \\
\left({\mathrm{L} . \mathrm{h}^{-1}}^{-1}\right)\end{array}$ & $\begin{array}{l}\text { Massa de } \\
\text { Eosina Y } \\
\text { aplicada } \\
(\mathrm{mg})\end{array}$ & $\begin{array}{c}\text { Massa } \\
\text { Molecular de } \\
\text { Eosina Y } \\
\left(\text { g.g-mol }{ }^{-1}\right)\end{array}$ & $\begin{array}{c}\text { Concentração } \\
\text { de traçador } \\
\left(\mathrm{mg} .20 \mathrm{~mL}^{-1}\right)\end{array}$ \\
\hline \multirow[t]{2}{*}{1} & 1 & 10 & 16,0 & 800 & & 40,0 \\
\hline & 2 & 10 & 16,0 & 442 & & 22,1 \\
\hline \multirow[t]{2}{*}{2} & 3 & var. ${ }^{1}$ & $* 40 \% . Q$ & 706 & 692,0 & 35,3 \\
\hline & 4 & var. & $* 40 \% . \mathrm{Q}$ & 436 & & 21,8 \\
\hline 3 & 5 & var. & $* * 60 \% . Q$ & 458 & & 22,9 \\
\hline
\end{tabular}

* Vazão senoidal cíclica com valores superiores e inferiores a 40\% da vazão média afluente ** Vazão senoidal cíclica com valores superiores e inferiores a $60 \%$ da vazão média afluente ${ }^{1}$ var. Valor variável

As curvas experimentais de concentração de traçador ao longo do tempo, $\mathrm{C}(\mathrm{t})$, foram normalizadas de acordo com Levenspiel (1999), resultando em curvas de distribuição do tempo de detenção hidráulica $\left(\mathrm{E}_{\theta}\right.$ em função do tempo adimensional $\theta)$, que possibilitaram o cálculo da variância para cada ensaio $\left(\sigma_{\theta}{ }^{2}\right)$. Os modelos teóricos uniparamétricos, de dispersão de pequena (PD) e de grande intensidade (GD) e de tanques em série (N-CSTR), foram utilizados para ajustar as curvas experimentais de distribuição do tempo de detenção hidráulica em função do tempo adimensional. A Tabela 8 apresenta os modelos hidrodinâmicos uniparamétricos de dispersão utilizados no ajuste das curvas experimentais de concentração de Eosina Y ao longo do tempo. 
Tabela 8. Modelos hidrodinâmicos uniparamétricos de dispersão (LEVENSPIEL, 1999)

\begin{tabular}{lcc}
\hline Modelo & Parâmetro & equação \\
\hline $\begin{array}{l}\text { Dispersão } \\
\text { de pequena } \\
\text { intensidade }\end{array}$ & $\sigma^{2}{ }_{\theta}=2\left(\frac{D}{u \cdot L}\right)$ & $E_{\theta}=\frac{1}{2 \sqrt{\pi(D / u \cdot L)}} \exp \left[-\frac{(1-\theta)^{2}}{4(D / u \cdot L)}\right]$ \\
\hline $\begin{array}{l}\text { Dispersão } \\
\text { de grande }\end{array}$ & $\sigma_{\theta, t a}^{2}=2\left(\frac{D}{u \cdot L}\right)+8\left(\frac{D}{u \cdot L}\right)^{2}$ & $E_{\theta, t a}=\frac{1}{2 \sqrt{\pi(D / u \cdot L)}} \exp \left[-\frac{(1-\theta)^{2}}{4 \theta(D / u \cdot L)}\right]$ \\
intensidade \\
(tanque \\
aberto) \\
$\begin{array}{c}\text { Tanques de } \\
\text { mistura } \\
\text { completa } \\
\text { em série }\end{array}$ \\
\hline
\end{tabular}

\section{Fonte: adaptado de Levenspiel (1999)}

Com aplicação das variações senoidais da vazão média afluente, foi necessário corrigir o valor da vazão em função de cada intervalo de tempo (t). Como a variação da vazão afluente a cada 15 min era realizada por programa computacional, foi possível adotar o valor da vazão corrigido em cada intervalo de tempo nos modelos teóricos uniparamétricos e posteriormente multiplicá-lo pela concentração medida de Eosina Y.

\subsection{PARTE TEÓRICA}

A parte teórica compreendeu a aplicação dos resultados experimentais obtidos com a operação do reator UASB, em escala piloto (160L), submetido a variações cíclicas diárias de cargas orgânicas e hidráulicas, como dados de entrada do modelo ADM1 (Anaerobic Digestion Model 1) desenvolvido por Batstone et al. (2002a,b) e do modelo matemático simplificado (MMS) desenvolvido por Carvalho e Pires (2002). 
Com o objetivo de estudar o modelo ADM1, um estágio de doutoramento foi

realizado no Centro Avançado de Gerenciamento de Águas Residuárias (Advanced Wastewater Management Centre/AWMC) da Universidade de Queensland na cidade de Brisbane, estado de Queensland na Austrália, no período de 22 de Novembro de 2004 a 23 de Junho de 2005.

A doutoranda contou em termos de supervisão dos estudos no exterior com a cooperação do Professor Dr. Jurg Keller na análise, interpretação, preparação e aplicação dos dados experimentais obtidos com a operação do reator UASB e dos dados teóricos obtidos com as simulações do modelo matemático ADM1; do Professor Associado Dr. Paul Lant na interpretação dos dados experimentais obtidos e no desenvolvimento e verificação dos balanços de massa do reator UASB; do Professor Associado Dr. Zhiguo Yuan na aplicação da ferramenta computacional Matlab para os ajustes necessários do modelo ADM1 no caso estudado.

\subsubsection{MODELO DE DIGESTÃO ANAERÓBIA (ADM1)}

O modelo ADM1 é um modelo matemático cuja estrutura é baseada na Demanda Química de Oxigênio (DQO), por essa medida corresponder a base unitária comumente aplicada na caracterização de águas residuárias.

Batstone et al. (2002a,b) desenvolveram esse modelo generalizado de digestão anaeróbia para diversos tipos de sistemas, considerando processos bioquímicos como processos irreversíveis e processos físico-químicos como reversíveis. O modelo descreve o processo de digestão anaeróbia em reator de mistura completa com fluxo contínuo.

A Figura 6 apresenta a sequiência dos processos envolvidos na digestão anaeróbia de compostos orgânicos particulados e solúveis do modelo ADM1. 


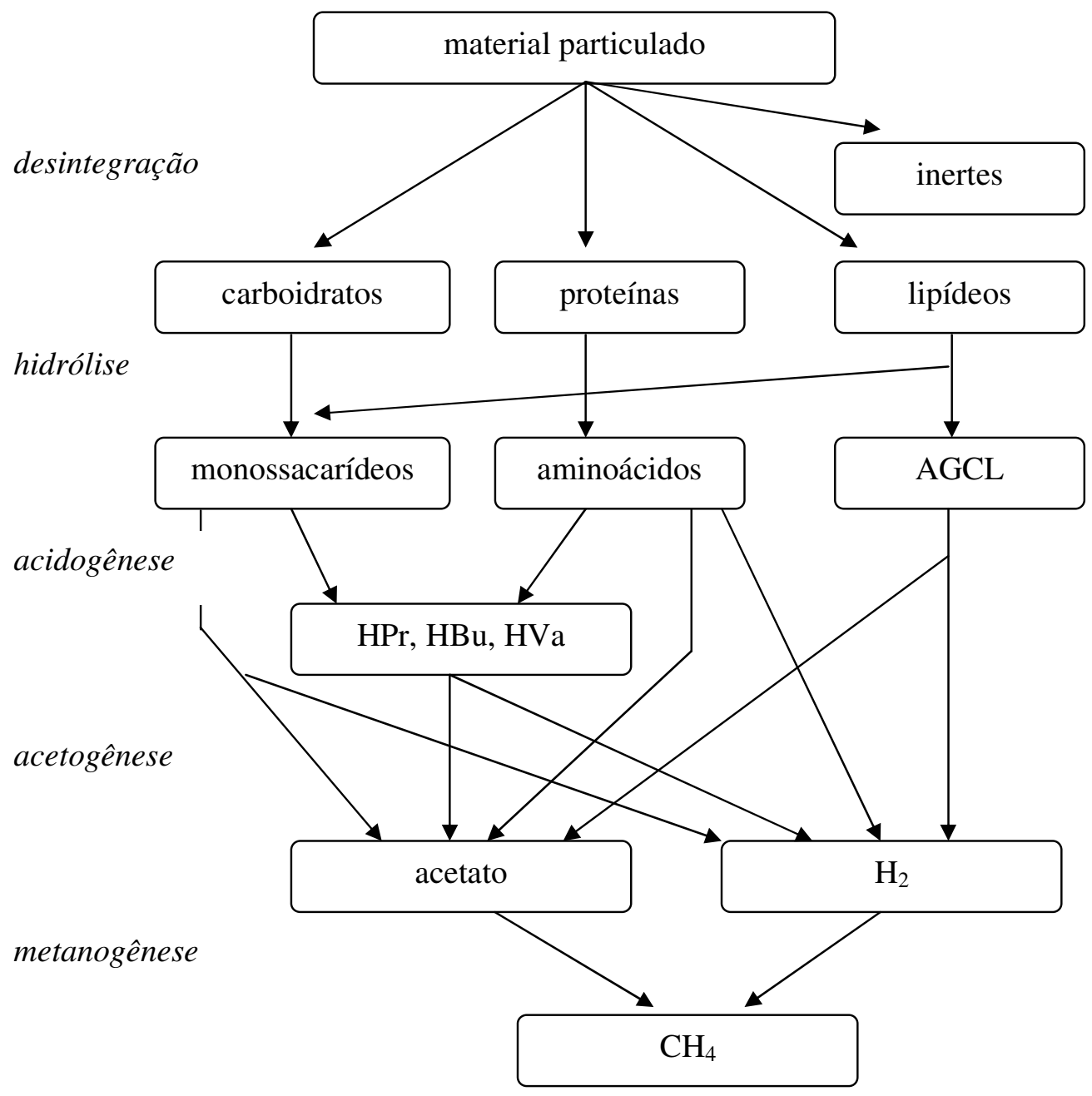

Figura 6. Sequiência de processos da digestão anaeróbia de macro moléculas complexas. Fonte: adaptado de Batstone et al. (2002a,b)

As etapas de desintegração e hidrólise são processos não biológicos e biológicos extracelulares, respectivamente, responsáveis pela quebra e solubilização da matéria orgânica complexa em substrato solúvel. A desintegração corresponde à etapa não biológica que converte o substrato particulado (matéria orgânica complexa, carboidratos, proteínas e lipídeos particulados) em carboidratos, proteínas e lipídeos particulados e em material inerte (solúvel e particulado). A inclusão dessa etapa no modelo ADM1 foi considerada inovadora em relação a outros modelos de digestão anaeróbia reportados na literatura técnico-científica, pois permite diversificar a aplicação do modelo para diversas unidades de tratamento, representar a "quebra" do 
lodo biológico e do material orgânico complexo (em carboidratos, proteínas e lipídeos) e recircular a biomassa anaeróbia "morta" (inerte).

A etapa da hidrólise foi representada pelo modelo conceitual de aderência dos microrganismos anaeróbios à superfície da partícula, que ocorre geralmente em sistemas de cultura mista. Esses microrganismos produzem enzimas na superfície da partícula e se beneficiam dos produtos solúveis liberados com a reação enzimática (VAVILIN, 1996; SANDERS, 2000). Os produtos da hidrólise enzimática de carboidratos, proteínas e lipídeos são monossacarídeos, aminoácidos e ácidos graxos de cadeia longa, respectivamente. Essas três sub-etapas hidrolíticas foram incluídas no modelo para diferenciar as velocidades da hidrólise desses substratos particulados definidos.

As etapas da acidogênese de açúcares e aminoácidos em ácidos graxos voláteis e hidrogênio e da acetogênese de ácidos graxos de cadeia longa e ácidos graxos voláteis (valerato, butirato e propionato) em acetato e da metanogênese de acetato e hidrogênio/gás carbônico são considerados processos intracelulares.

A etapa da acidogênese é geralmente definida como etapa intracelular de produção de ácidos sem a presença de um doador ou aceptor adicional de elétrons. Essa etapa inclui a degradação de monossacarídeos e aminoácidos solúveis em produtos mais simples. A degradação de ácidos graxos de cadeia longa é uma reação de oxidação com aceptor externo de elétrons. As reações da acidogênese podem ocorrer com concentrações elevadas de hidrogênio ou de formiato e elevada produção de biomassa, por não necessitarem de aceptor adicional de elétrons e pela elevada produção de energia livre.

O modelo ADM1 considerou a glicose como substrato da acidogênese de monossacarídeos e os ácidos acetato, propionato e butirato como produtos finais, por sua degradação em vias diferentes no processo de digestão anaeróbia e pela possibilidade de medição por cromatografia gasosa. Apesar de serem também produtos da acidogênese da glicose, o lactato e o etanol não foram contemplados no modelo devido às baixas concentrações encontradas na maioria dos reatores anaeróbios.

A acidogênese de aminoácidos foi considerada no modelo como reações de óxido-redução Stickland por serem reações mais rápidas do que as reações de 
oxidação de um aminoácido por íons de hidrogênio ou dióxido de carbono como aceptor externo de elétrons (BARKER, 19815 apud BATSTONE, et al., 2002a,b). Como as reações Stickland não são geralmente inibidas pela presença de hidrogênio, não foram consideradas funções reguladoras de hidrogênio ou de inibição na acidogênese de aminoácidos.

A acetogênese de ácidos graxos de cadeia longa em acetato é um processo de oxidação, sem a presença de aceptores internos de elétrons. Assim, os microrganismos que oxidam os ácidos voláteis de cadeia longa necessitam de aceptor adicional de elétrons como íons de hidrogênio e dióxido de carbono para produzir gás hidrogênio ou formiato, respectivamente. Esses transportadores de elétrons devem ser mantidos em baixa concentração para que a reação de oxidação seja termodinamicamente possível e para que o hidrogênio e o formiato sejam consumidos pelos organismos metanogênicos (arquéias). O modelo ADM1 adotou apenas o hidrogênio como transportador de elétrons. O modelo cinético de inibição não-competitiva pela presença de hidrogênio é adotado na acetogênese para reduzir a complexidade e aumentar a flexibilidade de uso do modelo ADM1.

O decaimento celular é descrito como produção de material inerte e de matéria orgânica degradada (compostos), o qual retorna à etapa de desintegração.

O modelo ADM 1 considerou três grupos de microrganismos acetogênicos que degradam separadamente butirato/valerato, propionato e ácidos graxos de cadeia longa devido às dificuldades de transporte e às diferenças de características físico-químicas dessas macromoléculas. Foram ainda considerados um grupo de microrganismos metanogênicos hidrogenotróficos e um grupo de microrganismos metanogênicos acetoclásticos. Todos os grupos de microrganismos possuem diferentes parâmetros cinéticos e de inibição que dependem do tipo de aplicação e de observações experimentais.

O modelo cinético de primeira ordem foi adotado para as etapas extracelulares de desintegração (parcialmente não-biológica) e hidrólise enzimática de proteínas, carboidratos e lipídeos. A aplicação desse modelo cinético para essas etapas é justificada pelo uso em diversas pesquisas reportadas na literatura técnico-científica,

${ }^{5}$ Barker, H.A. (1981). Amino acid degradation by anaerobic bacteria. Ann. Rev. Biochem, v.50, p.23-40. 
pela diversidade e complexidade dessas etapas que não permitem uma aproximação fundamental para um modelo genérico.

As etapas intracelulares são descritas pelas expressões de consumo de substrato, crescimento e decaimento microbiano. A equação principal do modelo é relacionada ao consumo de substrato baseado no modelo cinético de Monod para possibilitar a separação dos termos de crescimento microbiano e de consumo de substrato. O termo de decaimento microbiano é representado pelo modelo cinético de primeira ordem.

\subsubsection{PROCESSOS EXCLUÍDOS DO MODELO ADM1}

Alguns processos foram excluídos do modelo a fim de reduzir sua complexidade, tais como: produção de lactato a partir da fermentação de glicose; redução de sulfato e inibição por sulfeto; redução de nitrato; inibição por ácidos graxos de cadeia longa; consumo competitivo de $\mathrm{H}_{2}$ e de $\mathrm{CO}_{2}$ entre as arquéias metanogênicas hidrogenotróficas e os microrganismos homoacetogênicos (significantes em sistemas psicrofílicos); precipitação de sólidos devido a alcalinidade elevada ou a outras reações de precipitação química.

Outros processos que também foram excluídos do ADM1 são apresentados no APÊNDICE 8.1.

\subsubsection{MODELOS DE INIBIÇÃO}

A toxicidade pela presença de ácidos graxos de cadeia longa, detergentes, aldeídos, compostos de nitrogênio e antibióticos foi considerada como processo irreversível no modelo. Como a toxicidade pode influenciar na taxa de decaimento celular é muito importante separá-la da inibição na modelação, que pode influenciar na cinética de consumo de substrato e de crescimento celular (velocidade máxima de consumo de substrato, coeficiente de produção e de meia saturação).

Os modelos de inibição reversíveis foram adotados devido à presença dos produtos das reações, do par ácido fraco/base (ácidos graxos voláteis, amônia e gás sulfídrico), do $\mathrm{pH}$ e de outros fatores que podem prejudicar o equilíbrio do sistema.

Os modelos cinéticos de inibição considerados no modelo ADM1 correspondem: às formas reversíveis propostas por Lehninger (1975) com uso 
extensivo do modelo de inibição não-competitiva; influência do inibidor no crescimento e decaimento microbiano; duas fórmulas empíricas usadas para inibição pelo $\mathrm{pH}$; consumo competitivo, considerado como complemento apesar de não ser modelo de inibição; modelo cinético de Monod para substrato secundário necessário para descrever a diminuição do crescimento celular pela limitada concentração de nitrogênio (incluído como complemento no modelo e não como modelo de inibição).

Poucos mecanismos de inibição foram considerados para reduzir a complexidade do ADM1, conforme apresentado na Tabela 9.

Tabela 9. Formas de inibição

\begin{tabular}{|c|c|c|}
\hline descrição & equação & usos \\
\hline Inibição não-competitiva & $I=\frac{1}{1+S_{I} / K_{I}}$ & $\begin{array}{l}\text { Inibição por amônia } \\
\text { livre e hidrogênio }\end{array}$ \\
\hline Inibição Acompetitiva & $\rho_{j}=\frac{k_{m} X S}{K_{S}+S\left(1+\frac{K_{I}}{S_{I}}\right)}$ & Não usada \\
\hline Inibição Competitiva & $\rho_{j}=\frac{k_{m} X S}{K_{S}+S\left(1+\frac{K_{I}}{S_{I}}\right)+S}$ & Não usada \\
\hline Redução na produção & $Y=f\left(S_{I}\right)$ & \\
\hline $\begin{array}{l}\text { Aumento da velocidade } \\
\text { de decaimento biológico }\end{array}$ & $k_{d e c}=f\left(S_{I}\right)$ & Não usada \\
\hline $\begin{array}{c}\text { Inibição empírica } \\
\text { (valores altos e baixos de } \\
\text { pH) }\end{array}$ & $I=\frac{1+2 \times 10^{0.5\left(p H_{L L}-p H_{U L}\right)}}{1+10^{\left(p H-p H_{U L}\right)}+10^{\left(p H_{L L}-p H\right)}}$ & Inibição pelo pH \\
\hline $\begin{array}{c}\text { Inibição empírica } \\
\text { (valores baixos de } \mathrm{pH} \text { ) }\end{array}$ & $I=\exp \left(-3\left(\frac{p H-p H_{U L}}{p H_{U L}-p H_{L L}}\right)^{2}\right)$ & Inibição pelo $\mathrm{pH}$ \\
\hline Consumo competitivo & $I=\frac{1}{1+S_{I} / S}$ & $\begin{array}{c}\text { Competição de } \\
\text { butirato e valerato } \\
\text { por microrganismos } \\
\text { (C4) }\end{array}$ \\
\hline $\begin{array}{l}\text { Substrato secundário } \\
\text { (baixa concentração de } \\
\text { nitrogênio inorgânico) }\end{array}$ & $I=\frac{1}{1+K_{I} / S_{I}}$ & $\begin{array}{l}\text { Todos os consumos, } \\
\text { para inibir consumo }\end{array}$ \\
\hline
\end{tabular}

Fonte: adaptado de Batstone et al. (2002a,b) 
O modelo de inibição não-competitiva foi aplicado no ADM1 por ser amplamente reportado na literatura técnico-científica, possibilitando a obtenção de alguns parâmetros de inibição diretamente aplicáveis a esse modelo. Outros modelos de inibição devem ser mais adequados para inibição pela presença de hidrogênio ou de ácidos orgânicos, porém há ainda falta de conhecimento mais aprofundado que permita tal implementação.

$\mathrm{O}$ modelo de inibição pelo $\mathrm{pH}$ considerou a diminuição do equilíbrio do sistema (homeostase) e o aumento da concentração de ácidos fracos em sistemas com baixo pH, ou inibição pela presença de bases fracas e limitações de transporte de substrato em sistemas com elevado $\mathrm{pH}$. O modelo de inibição pelo $\mathrm{pH}$ foi usado nas equações de consumo de substrato para todos os processos intracelulares no ADM1 $\left(\mathrm{I}_{\mathrm{pH}}\right)$ com diferentes parâmetros para os microrganismos acidogênicos e acetogênicos, metanogênicos hidrogenotróficos e metanogênicos acetoclásticos. A inibição devido a altos e baixos valores de $\mathrm{pH}$ pode ser aplicada em sistemas tamponados pela presença de amônia ou por outras bases com valores de $\mathrm{pH}$ superiores a 8. A segunda função para $\mathrm{pH}$ é mais flexível e pode ser usada quando ocorre inibição devido a baixos valores de $\mathrm{pH}$ no sistema. Baixos ou elevados valores de $\mathrm{pH}$ podem inibir a hidrólise devido à desnaturação parcial das enzimas, porém esse modelo de inibição não foi considerado no ADM1.

Os efeitos da inibição pela presença de ácidos orgânicos livres foram inclusos implicitamente no modelo empírico de $\mathrm{pH}$. A inibição pela presença de amônia livre pode ser incluída empiricamente na função de altos e baixos valores de $\mathrm{pH}$ ou explicitamente na função de inibição pela presença de amônia livre. A inibição pela presença de gás sulfídrico não foi contemplada no ADM1 uma vez que a redução de sulfato também não foi incluída no modelo.

A inibição dos microrganismos acetogênicos pela presença de hidrogênio e dos microrganismos metanogênicos acetoclásticos pela presença de amônia foram descritos no ADM1 como modelos de inibição não-competitivos.

O efeito tóxico dos ácidos graxos de cadeia longa não foi contemplado no modelo de digestão anaeróbia, pois o ADM1 não descreve o comportamento de reatores submetidos a elevadas concentrações desses ácidos devido à complexidade dessas macromoléculas e a baixa freqüência desse tipo de inibição. 


\subsubsection{EFEITO DA TEMPERATURA}

O ADM1 considera um valor ótimo para a temperatura baseado na equação de Arrhenius. Os sistemas contemplados pelo modelo foram: sistema com pequenas variações de temperatura e sem dependência da temperatura de operação, com parâmetros ajustados para a temperatura de operação; sistema com variação da temperatura em faixa conhecida (mesofílica e termofílica) com aplicação da equação de Arrhenius para descrever o rápido decréscimo da atividade microbiana em elevadas temperaturas; sistema com variações de temperatura entre as faixas mesofílica e termofílica, com variações regulares das populações microbianas e dos caminhos das reações.

Diferentes valores para os parâmetros velocidades de crescimento e de decaimento microbiano foram considerados pelo modelo nas condições mesofílicas e termofílicas.

Alterações na cinética de primeira ordem das etapas de desintegração e de hidrólise podem ocorrer devido a variações da temperatura. O modelo ADM1 considera possível explicar essas variações com o uso da equação de Arrhenius. A conversão direta de hidrogênio e acetato a metano foi contemplada no modelo, sem as etapas de homoacetogênese e de oxidação de acetato.

\subsubsection{PROCESSOS FÍSICO-QUÍMICOS}

Os processos físico-químicos descritos que incluem associação e dissociação iônica (processos líquido-líquido) e transferência da fase gasosa para a líquida (processos gasoso-líquido) foram contemplados no ADM1. Os processos de precipitação/solubilização (processo sólido-líquido) não foram considerados no ADM1 devido à complexidade de aplicação, apesar de serem de suma importância em sistemas com formação de precipitados de cálcio $\left(\mathrm{Ca}^{2+}\right)$ e magnésio $\left(\mathrm{Mg}^{2+}\right)$.

A correção do comportamento não ideal dos íons que poderia influenciar nos processos físico-químicos não foi considerada no ADM1. As espécies iônicas 
consideradas no modelo e seus coeficientes de equilíbrio são apresentadas na Tabela 10.

Tabela 10. Coeficientes de equilíbrio do par ácido/base $\left(\mathrm{pK}_{\mathrm{a}}\right)$

\begin{tabular}{|c|c|c|c|}
\hline par ácido/base & $\begin{array}{c}\mathrm{pK}_{\mathrm{a}} \\
(298 \mathrm{~K})\end{array}$ & $\tilde{\Delta} \mathrm{H}\left(\mathrm{J} \cdot \mathrm{mole}^{-1}\right)$ & $\left.\theta\left(=\Delta \mathrm{H}^{0} / \mathrm{RT}_{1}^{2}\right)\right) ; \mathrm{T} 1=298 \mathrm{~K}$ \\
\hline $\mathrm{CO}_{2} / \mathrm{HCO}_{3}^{-}$ & 6,35 & 7646 & 0,010 \\
\hline $\mathrm{NH} 4_{+} / \mathrm{NH} 3$ & 9,25 & 51965 & 0,070 \\
\hline $\mathrm{H}_{2} \mathrm{~S} / \mathrm{HS}$ & 7,05 & 21670 & 0,029 \\
\hline $\mathrm{H}_{2} \mathrm{O} /\left(\mathrm{OH}^{-}+\mathrm{H}^{+}\right)$ & 14,00 & 55900 & 0,076 \\
\hline $\mathrm{Hac} / \mathrm{Ac}^{-}$ & 4,76 & máximo de 4,81 (333 K) & $\mathrm{n} / \mathrm{a}$ \\
\hline $\mathrm{HPr} / \mathrm{Pr}^{-}$ & 4,88 & máximo de 4,94 (333 K) & $\mathrm{n} / \mathrm{a}$ \\
\hline $\mathrm{n}-\mathrm{HBu} / \mathrm{Bu}^{-}$ & 4,82 & máximo de 4,92 (333 K) & $\mathrm{n} / \mathrm{a}$ \\
\hline $\mathrm{i}-\mathrm{HBu} / \mathrm{Bu}^{-}$ & 4,86 & - & $\mathrm{n} / \mathrm{a}$ \\
\hline $\mathrm{n}-\mathrm{Hva} / \mathrm{Va}^{-}$ & 4,86 & - & $\mathrm{n} / \mathrm{a}$ \\
\hline $\mathrm{i}-\mathrm{HVa} / \mathrm{Va}^{-}$ & 4,78 & - & $\mathrm{n} / \mathrm{a}$ \\
\hline
\end{tabular}

Fonte: adaptado de Batstone et al. (2002a,b)

O processo físico-químico de stripping dos compostos gasosos: hidrogênio, metano e gás carbônico foi incluído no modelo para representar a produção de biogás.

\subsubsection{BALANÇO DE CARGA}

O balanço de carga foi aplicado no ADM1 para formular as equações que descrevem as reações ácido/base devido a maior facilidade de compreensão e ao valor educacional dessa aplicação. O balanço de carga foi expresso como a diferença entre as somatórias das concentrações de cátions e ânions (Equação 1).

$\sum S_{C^{+}}-\sum S_{A^{-}}=0$ 
em que: $\sum S_{C^{+}}$representa a concentração equivalente total de cátions e $\sum S_{A^{-}}$ representa a concentração equivalente total de ânions. A concentração equivalente de cada íon corresponde a sua valência multiplicada pela concentração molar.

No balanço de carga, os denominadores dos ácidos orgânicos representam a concentração de matéria orgânica em termos de DQO por carga (Equação 2).

$S_{\mathrm{Cat}^{+}}+S_{\mathrm{NH}_{4}{ }^{+}}+S_{\mathrm{H}^{+}}-S_{\mathrm{HCO}_{3}{ }^{-}}-\frac{S_{\mathrm{Ac}^{-}}}{64}-\frac{S_{\mathrm{Pr}^{-}}}{112}-\frac{S_{\mathrm{Bu}^{-}}}{160}-\frac{S_{\mathrm{Va}^{-}}}{208}-S_{\mathrm{OH}^{-}}-S_{\mathrm{An}^{-}}=0 \quad$ Equação 2

em que:

$S_{\mathrm{Cat}^{+}}$e $S_{\mathrm{An}^{-}}$representam as concentrações de íons metálicos, tais como $\mathrm{Na}^{+}$e $\mathrm{Cl}^{-}$, adotados como ácidos e bases fortes;

$S_{\mathrm{NH}_{4}{ }^{+}}$representa a concentração de íons amônio, $[\mathrm{kmol} \mathrm{N}] \cdot\left[\mathrm{m}^{-3}\right]$;

$S_{H^{+}}$representa a concentração de íons hidrogênio, $\left[\mathrm{kmol} \mathrm{H} \mathrm{H}^{+}\right] \cdot\left[\mathrm{m}^{-3}\right]$;

$S_{\mathrm{HCO}_{3}^{-}}$a concentração de íons carbonato, $[\mathrm{kmol} \mathrm{C}] \cdot\left[\mathrm{m}^{-3}\right]$;

$S_{A c^{-}}$a concentração de íons acetato, $[\mathrm{kgDQO}] \cdot\left[\mathrm{m}^{-3}\right]$;

$S_{\mathrm{Pr}^{-}}$a concentração de íons propionato, [kgDQO].[m" $\left.{ }^{-3}\right]$;

$S_{B u^{-}}$a concentração de íons butirato, $[\mathrm{kgDQO}] .\left[\mathrm{m}^{-3}\right]$;

$S_{V a^{-}}$a concentração de íons valerato, $[\mathrm{kgDQO}] \cdot\left[\mathrm{m}^{-3}\right]$;

$S_{O H^{-}}$a concentração de íons hidróxido, [kgDQO].[m" $\left.{ }^{-3}\right]$;

Por outro lado, $S_{\mathrm{Cat}^{+}}$e $S_{\mathrm{An}^{-}}$podem ser considerados como compostos inertes sem termos de consumo ou de reação.

Os ácidos graxos de cadeia longa (AGCL) não foram considerados como parte do sistema ácido/base do modelo devido ao pequeno número de sítios de cargas por grama de DQO. Por outro lado, esses ácidos devem ser considerados como ácidos graxos voláteis (AGV), se estiverem em elevada concentração ou se foram considerados inibidores.

As reações ácido/base devido à presença de aminoácidos não foram incluídas no modelo devido à baixa concentração desses compostos comumente encontrada nos 
reatores, às elevadas velocidades de acidogênese e à ampla faixa de valores de $\mathrm{pK}_{\mathrm{a}}$ para aminoácidos.

Se as equações do par ácido/base forem aplicadas no modelo como um conjunto de equações algébricas, a concentração combinada do par ácido/base deve ser expressa como variável de estado. Para o carbono inorgânico a variável resulta em

$$
\begin{array}{ll}
S_{I C}-S_{\mathrm{CO}_{2}}-S_{\mathrm{HCO}_{3}^{-}}=0 & \text { Equação 3 }
\end{array}
$$

As equações algébricas remanescentes podem ser formuladas a partir de equações de equilíbrio do par ácido/base, por exemplo para o par gás carbônico/carbonato de cálcio (Equação 4).

$S_{\mathrm{HCO}_{3}^{-}}-\frac{K_{a, \mathrm{CO}_{2}} S_{I C}}{K_{a, \mathrm{CO}_{2}}+S_{\mathrm{H}^{+}}}=0$

\section{Equação 4}

em que: $\mathrm{K}_{a, \mathrm{CO}_{2}}$ corresponde ao coeficiente de equilíbrio.

Para os ácidos orgânicos, nitrogênio inorgânico e hidróxido, as equações algébricas foram formuladas de acordo com as equações 5, 6 e 7 .

$S_{V F A^{-}}-\frac{K_{a, V F A} S_{V F A, t o t a l}}{K_{a, V F A}+S_{H^{+}}}=0$

Equação 5

$S_{N H_{4}^{+}}-\frac{S_{H^{+}} S_{I N}}{K_{a, N H_{4}}+S_{H^{+}}}=0$

Equação 6

$S_{O H^{-}}-\frac{K_{W}}{S_{H^{+}}}=0$

Equação 7

Assim quando reações de ácidos e bases são aplicadas como um conjunto de equações algébricas implícitas, as formas livre $\left(\mathrm{S}_{\mathrm{CO}_{2}}\right)$ e iônica $\left(\mathrm{S}_{\mathrm{HCO}_{3}^{-}}\right)$são agrupadas como uma única variável de estado $\left(S_{I C} \equiv S_{3}\right.$ ). Portanto, a Equação 3 é suficiente para calcular a concentração do par ácido/base se for aplicada em outra parte do modelo ADM1. Os ácidos e bases calculados no ADM1 são $S_{\mathrm{CO}_{2}}$ e $S_{\mathrm{NH}_{3}}$.

Se as equações físico-químicas forem implementadas como equações diferenciais, as formas livre e total dos ácidos e bases são aplicadas como variáveis de 
estado, a forma agrupada é redundante e uma equação cinética de velocidade é adicionada para as reações ácido-base.

A concentração de hidróxido $\left(S_{O_{H^{-}}}\right)$da Equação 7 deve ser substituída na equação do balanço de carga para que a variável $S_{H^{+}}$(concentração de íons de hidrogênio) seja a única incógnita da Equação 2. Um método de solução mista também pode ser utilizado, com um número de reações físico-químicas aplicadas como equações cinéticas de velocidade, e a parte restante como um conjunto de equações algébricas implícitas.

Os gases hidrogênio $\left(\mathrm{H}_{2}\right)$, metano $\left(\mathrm{CH}_{4}\right)$ e dióxido de carbono $\left(\mathrm{CO}_{2}\right)$ foram considerados importantes como produtos intermediários nos processos biológicos. $\mathrm{O}$ gás sulfidrico $\left(\mathrm{H}_{2} \mathrm{~S}\right)$ não foi considerado no $\mathrm{ADM} 1$ porque a redução de sulfato não foi incluída como processo bioquímico no modelo. A amônia $\left(\mathrm{NH}_{3}\right)$ é tão solúvel que o fluxo de massa para gás não é considerado quando comparado àquele no efluente.

\subsubsection{EFEITO DO pH}

$\mathrm{O}$ cálculo do $\mathrm{pH}$ é baseado em seis processos físico-químicos adicionais, que descrevem o equilíbrio ácido/base de carbonato/bicarbonato, íon amônio/amônia, ácido acético/acetato, ácido propiônico/propionato, ácido butírico/butirato e ácido valérico/valerato.

As variáveis de estado que representam as concentrações de cátions e ânions foram introduzidas no modelo para demonstrar a influência das cargas iônicas positivas e negativas no $\mathrm{pH}$ do sistema.

\subsubsection{ESTRUTURA DO MODELO}

O comportamento do reator é definido por 26 ou 32 variáveis de estado, dependendo do tipo de implementação adotado. O modelo ADM1 expressa todo o sistema anaeróbio como uma matriz de equações de taxa, tal como o modelo ASM1 (Anaerobic Sludge Model 1) proposto por Henze et al. (1987). 


\subsubsection{VARIÁVEIS DE ESTADO DINÂMICO}

O modelo ADM1 é formado por 32 variáveis de estado dinâmico de concentração, envolvendo 19 processos bioquímicos de taxas e de transferência da fase gasosa para líquida e 6 processos cinéticos adicionais do par ácido-base, quando considerado como conjunto de equações diferenciais ordinárias (EDO).

Os estados dinâmicos de concentração de ácidos graxos voláteis $\left(S_{f a}\right)$, carbono inorgânico $\left(S_{I C}\right)$ e nitrogênio inorgânico $\left(S_{I N}\right)$ são divididos em dois componentes na dissociação dos ácidos e bases em sistemas aquáticos.

\subsubsection{MATRIZ DE EQUAÇÃO DE TAXA}

A Tabela 11 e a Tabela 12 apresentam as 32 variáveis de estado estruturadas na forma matricial com coeficientes para reações bioquímicas e cinéticas.

A matriz original proposta por Batstone et al. (2002a,b) foi modificada para incluir as reações físico-químicas que descrevem o efeito dos estados físico-químicos, tais como $\mathrm{pH}$ nas reações bioquímicas. 
Tabela 11. Coeficientes bioquímicos $\left(v_{i}, j\right)$ e equações cinéticas $\left(\rho_{j}\right)$ para os compostos solúveis $(i=1-12 ; j=1-19)$

\begin{tabular}{|c|c|c|c|c|c|c|c|c|c|c|c|c|c|c|c|c|c|}
\hline & componente $\rightarrow \mid \mathbf{i}$ & 1 & 2 & 3 & 4 & 5 & 6 & 7 & 8 & 9 & 10 & 11 & 12 & 13 & 14 & 15 & $\operatorname{taxa}\left(\rho j, k g\right.$ DQO.m $\left.{ }^{-3} \cdot d^{-1}\right)$ \\
\hline $\mathbf{j}$ & processo $\downarrow$ & $\mathrm{S}_{\mathrm{su}}$ & $\mathrm{S}_{\mathrm{aa}}$ & $\mathrm{S}_{\mathrm{fa}}$ & $S_{\text {hva }}$ & $\mathrm{S}_{\mathrm{va}}$ & $\mathrm{S}_{\mathrm{hbu}}$ & $S_{\mathrm{bu}}$ & $S_{\text {hpro }}$ & $\mathrm{S}_{\mathrm{pro}}$ & $\mathrm{S}_{\text {hac }}$ & $\mathrm{S}_{\mathrm{ac}}$ & $S_{\mathrm{h} 2}$ & $\mathrm{~S}_{\mathrm{ch} 4}$ & $\mathrm{~S}_{\mathrm{CO} 2}$ & $\mathrm{~S}_{\mathrm{HCO} 3}$ & \\
\hline 1 & desintegração & & & & & & & & & & & & & & & & $k_{\text {diss }} \cdot X_{c}$ \\
\hline 2 & hidrólise de carboidratos & 1 & & & & & & & & & & & & & & & $k_{h v d, c h} \cdot X_{c h}$ \\
\hline 3 & hidrólise de proteínas & & 1 & & & & & & & & & & & & & & $k_{h y d, p r} \cdot X_{p r}$ \\
\hline 4 & hidrólise de lipídeos & $\left(1-f_{f a, l i}\right)$ & & $f_{f a, l i}$ & & & & & & & & & & & & & $k_{h v d d i} \cdot X_{l i}$ \\
\hline 5 & consumo de su & -1 & & & & & & $\left(1-Y_{s u}\right) f_{b u, s u}$ & & $\left(1-Y_{s u}\right) f_{p r o, s u}$ & & $\left(1-Y_{s u}\right) f_{a c, s u}$ & $\left(1-Y_{s u}\right) f_{h 2, s u}$ & & & $\sum_{i=1-13,16-30} C_{i} V_{i, 5}$ & $k_{m, s u} \cdot \frac{S_{s u}}{K_{S, s u}+S_{s u}} \cdot X_{s u} \cdot I_{5}$ \\
\hline 6 & consumo de aa & & -1 & & & $\left(1-Y_{a a}\right) f_{v a, a a}$ & & $\left(1-Y_{a a}\right) f_{b u, a a}$ & & $\left(1-Y_{a a}\right) f_{p r o, a a}$ & & $\left(1-Y_{a a}\right) f_{a c, a a}$ & $\left(1-Y_{a a}\right) f_{h 2, a a}$ & & & $-\sum_{i=1-13,16-30} C_{i} v_{i, 6}$ & $k_{m, a a} \cdot \frac{S_{a a}}{K_{S, a a}+S_{a a}} \cdot X_{a a} \cdot I_{6}$ \\
\hline 7 & consumo de fa & & & -1 & & & & & & & & $\left(1-Y_{f a}\right) 0.7$ & $\left(1-Y_{f a}\right) 0.3$ & & & & $k_{m, f a} \cdot \frac{S_{f a}}{K_{S, f a}+S_{f a}} \cdot X_{f a} \cdot I_{7}$ \\
\hline 8 & consumo de va & & & & & -1 & & & & $\left(1-Y_{c 4}\right) 0.54$ & & $\left(1-Y_{c 4}\right) 0.31$ & $\left(1-Y_{c 4}\right) 0.15$ & & & & $k_{m, c 4} \cdot \frac{S_{v a}}{K_{S, c 4}+S_{v a}} \cdot X_{c 4} \cdot \frac{S_{v a}}{S_{b u}+S_{v a}+1 e^{-6}} I_{8}$ \\
\hline 9 & consumo de bu & & & & & & & -1 & & & & $\left(1-Y_{c 4}\right) 0.8$ & $\left(1-Y_{c 4}\right) 0.2$ & & & & $k_{m, c 4} \cdot \frac{S_{b u}}{K_{S, c 4}+S_{b u}} \cdot X_{c 4} \cdot \frac{S_{b u}}{S_{b u}+S_{v a}+1 e^{-6}} I_{9}$ \\
\hline 10 & consumo de pro & & & & & & & & & -1 & & $\left(1-Y_{p r o}\right) 0.57$ & $\left(1-Y_{\text {pro }}\right) 0.43$ & & & $\sum_{i=1-13,16-30} C_{i} v_{i, 10}$ & $k_{m, p r o} \cdot \frac{S_{p r o}}{K_{S, p r o}+S_{p r o}} \cdot X_{p r o} \cdot I_{10}$ \\
\hline 11 & consumo de ac & & & & & & & & & & & -1 & & $\left(1-Y_{a c}\right)$ & & $\sum_{i=1-13,16-30} C_{i} V_{i, 11}$ & $k_{m, a c} \cdot \frac{S_{a c}}{K_{S, a c}+S_{a c}} \cdot X_{a c} \cdot I_{11}$ \\
\hline 12 & consumo de $\mathrm{h}_{2}$ & & & & & & & & & & & & & $\left(1-Y_{h 2}\right)$ & & $\sum_{i=1-13,16-30} C_{i} v_{i, 12}$ & $k_{m, h 2} \cdot \frac{S_{h 2}}{K_{S, h 2}+S_{h 2}} \cdot X_{h 2} \cdot I_{12}$ \\
\hline 13 & decaimento de $\mathrm{X}_{\mathrm{su}}$ & & & & & & & & & & & & & & & $\sum_{i=19232^{2}-29} C_{i} v_{i, 13}$ & $k_{d e c, x s u} \cdot X_{s u}$ \\
\hline 14 & decaimento de $X_{\text {aa }}$ & & & & & & & & & & & & & & & $-\sum_{i=19,23-29} C_{i} V_{i, 14}$ & $k_{d e c, x a a} \cdot X_{a a}$ \\
\hline 15 & decaimento de $\mathrm{X}_{\mathrm{fa}}$ & & & & & & & & & & & & & & & $\sum_{i=10223-29} C_{i} v_{i, 15}$ & $k_{d e c, x f a} \cdot X_{f a}$ \\
\hline 16 & decaimento de $\mathrm{X}_{\mathrm{C} 4}$ & & & & & & & & & & & & & & & $\sum_{i=1023-20} C_{i} V_{i, 16}$ & $k_{d e c, x c 4} \cdot X_{c 4}$ \\
\hline 17 & decaimento de $X_{\text {pro }}$ & & & & & & & & & & & & & & & $\sum_{i=19,23-29} C_{i} V_{i, 17}$ & $k_{\text {dec,xpro }} \cdot X_{\text {pro }}$ \\
\hline 18 & decaimento de $X_{\mathrm{ac}}$ & & & & & & & & & & & & & & & $\sum_{i=19.23-29} C_{i} v_{i, 18}$ & $k_{d e c a c} \cdot X_{a c}$ \\
\hline 19 & decaimento de $\mathrm{X}_{\mathrm{h} 2}$ & & & & & & & & & & & & & & & $-\sum_{i=19,23-29} C_{i} v_{i, 19}$ & $k_{\text {dec } h 2} \cdot X_{h 2}$ \\
\hline A4 & ácido-base va & & & & 1 & -1 & & & & & & & & & & & $k_{A, B v a}\left(S_{v a}-\left(K_{a, v a}+S_{H^{+}}\right)-k_{a, v a} S_{v a}\right.$ \\
\hline A5 & ácido-base bu & & & & & & 1 & -1 & & & & & & & & & $k_{A, B b u}\left(S_{b u}-\left(K_{a, b u}+S_{H^{+}}\right)-k_{a, b u} S_{b u}\right.$ \\
\hline A6 & ácido-base pro & & & & & & & & 1 & -1 & & & & & & & $k_{A, \text { Bpro }}\left(S_{\text {pro }}-\left(K_{a, p r o}+S_{H^{+}}\right)-k_{a, p r o} S_{p r o}\right.$ \\
\hline A7 & ácido-base ac & & & & & & & & & & 1 & -1 & & & & & $k_{A, B a c}\left(S_{a c}-\left(K_{a, a c}+S_{H^{+}}\right)-k_{a, a c} S_{a c}\right.$ \\
\hline A10 & ácido-base CI & & & & & & & & & & & & & & 1 & -1 & $k_{A, B c o 2}\left(S_{h c o 3}-\left(K_{a, c o 2}+S_{H^{+}}\right)-k_{a, c o 2} S_{I C}\right.$ \\
\hline A11 & ácido-base NI & & & & & & & & & & & & & & & & $k_{A, B I N}\left(S_{n h 3}-\left(K_{a, I N}+S_{H^{+}}\right)-k_{a, I N} S_{I N}\right.$ \\
\hline & $\begin{array}{l}\text { unidades: } \\
\text { *kgDQO.m }{ }^{-3} \\
\text { **k-molC.m }{ }^{-3}\end{array}$ & 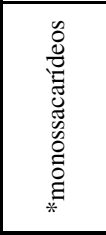 & 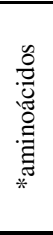 & 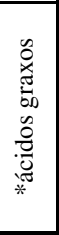 & 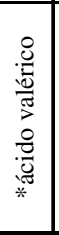 & 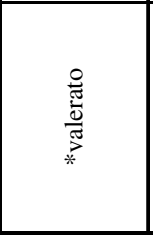 & 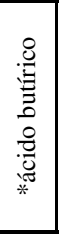 & 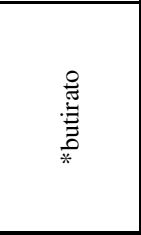 & 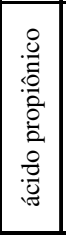 & 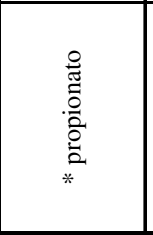 & 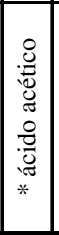 & 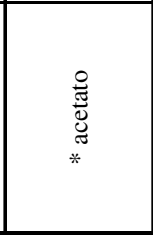 & 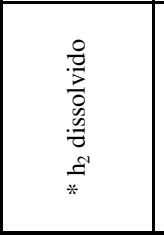 & 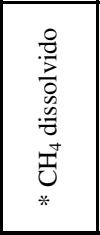 & 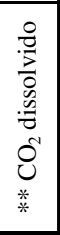 & 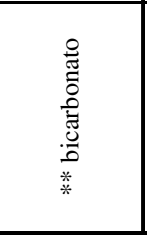 & $\begin{array}{l}I_{5,6}=I_{p H, a a} \cdot I_{I N, \lim } \\
I_{7}=I_{p H, a a} \cdot I_{I N, \lim } \cdot I_{h 2, f a} \\
I_{8,9}=I_{p H, a a} \cdot I_{I N, \lim } \cdot I_{h 2, c 4} \\
I_{10}=I_{p H, a a} \cdot I_{I N, \lim } \cdot I_{h 2, p r o} \\
I_{11}=I_{p H, a c} \cdot I_{I N, \lim } \cdot I_{n h 3} \\
I_{12}=I_{p H, h 2} \cdot I_{I N, \lim }\end{array}$ \\
\hline
\end{tabular}


Tabela 12. Coeficientes bioquímicos $\left(v_{i}, \mathbf{j}\right)$ e equações cinéticas $\left(\rho_{j}\right)$ para os compostos particulados $(i=13-24 ; j=1-19)$

\begin{tabular}{|c|c|c|c|c|c|c|c|c|c|c|c|c|c|c|c|c|c|c|c|}
\hline & componente $\rightarrow \mid$ i & 16 & 17 & 18 & 19 & 20 & 21 & 22 & 23 & 24 & 25 & 26 & 27 & 28 & 29 & 30 & 31 & 32 & $\operatorname{taxa}\left(\rho j, k g\right.$ DQO. $\left.\mathrm{m}^{-3} . \mathrm{d}^{-1}\right)$ \\
\hline $\mathbf{j}$ & $\begin{array}{r}\text { processo } \downarrow \\
\end{array}$ & $\mathrm{S}_{\mathrm{NH} 4}$ & $\mathrm{~S}_{\mathrm{NH} 3}$ & $\mathrm{~S}_{\mathrm{I}}$ & $X_{c}$ & $\mathrm{X}_{\mathrm{ch}}$ & $X_{\mathrm{pr}}$ & $\mathrm{X}_{\mathrm{li}}$ & $\mathrm{X}_{\mathrm{su}}$ & $X_{a a}$ & $\mathrm{X}_{\mathrm{fa}}$ & $X_{\mathrm{c} 4}$ & $\mathrm{X}_{\mathrm{pro}}$ & $\mathrm{X}_{\mathrm{ac}}$ & $\mathrm{X}_{\mathrm{h} 2}$ & $\mathrm{X}_{\mathrm{I}}$ & $\mathrm{S}_{\mathrm{CAT}}$ & $\mathrm{S}_{\mathrm{AN}}$ & \\
\hline 1 & desintegração & & & $f_{s I, x c}$ & -1 & $f_{c h, x c}$ & $f_{p r x c}$ & $f_{l i x y c}$ & & & & & & & & $f_{x i, x c}$ & & & $k_{\text {diss }} \cdot X_{c}$ \\
\hline 2 & hidrólise de carboidratos & & & & & -1 & & & & & & & & & & & & & $k_{h v d, c h} \cdot X_{c h}$ \\
\hline 3 & hidrólise de proteínas & & & & & & -1 & & & & & & & & & & & & $k_{h v d, p r} \cdot X_{p r}$ \\
\hline 4 & hidrólise de lipídeos & & & & & & & -1 & & & & & & & & & & & $k_{h v d l i} \cdot X_{l i}$ \\
\hline 5 & consumo de su & $-\left(Y_{s u}\right) N_{b a c}$ & & & & & & & $Y_{s u}$ & & & & & & & & & & $k_{m, s u} \cdot \frac{S_{s u}}{K_{S, s u}+S_{s u}} \cdot X_{s u} \cdot I_{5}$ \\
\hline 6 & consumo de aa & $N_{a a}-Y_{a a} N_{b a c}$ & & & & & & & & $Y_{a a}$ & & & & & & & & & $k_{m, a a} \cdot \frac{S_{a a}}{K_{S, a a}+S_{a a}} \cdot X_{a a} \cdot I_{6}$ \\
\hline 7 & consumo de fa & $-\left(Y_{f a}\right) N_{b a c}$ & & & & & & & & & $Y_{f a}$ & & & & & & & & $k_{m, f a} \cdot \frac{S_{f a}}{K_{S, f a}+S_{f a}} \cdot X_{f a} \cdot I_{7}$ \\
\hline 8 & consumo de va & $-\left(Y_{c 4}\right) N_{b a c}$ & & & & & & & & & & $Y_{c 4}$ & & & & & & & $k_{m, c 4} \cdot \frac{S_{v a}}{K_{S, c 4}+S_{v a}} \cdot X_{c 4} \cdot \frac{S_{v a}}{S_{b u}+S_{v a}+1 e^{-6}} I_{8}$ \\
\hline 9 & consumo de bu & $-\left(Y_{c 4}\right) N_{b a c}$ & & & & & & & & & & $Y_{c 4}$ & & & & & & & $k_{m, c 4} \cdot \frac{S_{b u}}{K_{S, c 4}+S_{b u}} \cdot X_{c 4} \cdot \frac{S_{b u}}{S_{b u}+S_{v a}+1 e^{-6}} I_{9}$ \\
\hline 10 & consumo de pro & $-\left(Y_{p r o}\right) N_{b a c}$ & & & & & & & & & & & $Y_{\text {pro }}$ & & & & & & $k_{m, p r o} \cdot \frac{S_{p r o}}{K_{S . p r o}+S_{p r o}} \cdot X_{p r o} \cdot I_{10}$ \\
\hline 11 & consumo de ac & $-\left(Y_{a c}\right) N_{b a c}$ & & & & & & & & & & & & $Y_{a c}$ & & & & & $k_{m, a c} \cdot \frac{S_{a c}}{K_{S, a c}+S_{a c}} \cdot X_{a c} \cdot I_{11}$ \\
\hline 12 & consumo de $\mathrm{h}_{2}$ & $\begin{array}{l}-\left(Y_{b 2}\right) N_{b a c} \\
-\quad \sum N v_{b u} \\
\end{array}$ & & & 1 & & & & & & & & & & $Y_{h 2}$ & & & & $k_{m, h 2} \cdot \frac{S_{h 2}}{K_{S, h 2}+S_{h 2}} \cdot X_{h 2} \cdot I_{12}$ \\
\hline 13 & decaimento de $\mathrm{X}_{\mathrm{su}}$ & $i=19,23-29$ & & & 1 & & & & -1 & & & & & & & & & & $k_{d e c, x s u} \cdot X_{s u}$ \\
\hline 14 & decaimento de $\mathrm{X}_{\mathrm{aa}}$ & $\sum_{i=19,23-29} N_{i} V_{i, 14}$ & & & 1 & & & & & -1 & & & & & & & & & $k_{d e c, x a a} \cdot X_{a a}$ \\
\hline 15 & decaimento de $\mathrm{X}_{\mathrm{fa}}$ & $-\sum_{i=19,23-29} N_{i} v_{i, 15}$ & & & 1 & & & & & & -1 & & & & & & & & $k_{d e c, x f a} \cdot X_{f a}$ \\
\hline 16 & decaimento de $\mathrm{X}_{\mathrm{C} 4}$ & $\sum_{i=19,23-29} N_{i} v_{i, 16}$ & & & 1 & & & & & & & -1 & & & & & & & $k_{d e c, x c 4} \cdot X_{c 4}$ \\
\hline 17 & decaimento de $X_{\text {pro }}$ & $\sum_{i=19,23-29} N_{i} v_{i, 17}$ & & & 1 & & & & & & & & -1 & & & & & & $k_{\text {dec,xpro }} \cdot X_{\text {pro }}$ \\
\hline 18 & decaimento de $\mathrm{X}_{\mathrm{ac}}$ & $-\sum_{i=19,23-29} N_{i} V_{i, 18}$ & & & 1 & & & & & & & & & -1 & & & & & $k_{d e c, a c} \cdot X_{a c}$ \\
\hline 19 & decaimento de $X_{\mathrm{h} 2}$ & $-\sum_{i=19,23-29} N_{i} V_{i, 19}$ & & & 1 & & & & & & & & & & -1 & & & & $k_{d e c, h 2} \cdot X_{h 2}$ \\
\hline $\mathbf{A 4}$ & ácido-base va & & & & & & & & & & & & & & & & & & $k_{A, B v a}\left(S_{v a}-\left(K_{a, v a}+S_{H^{+}}\right)-k_{a, v a} S_{v a}\right.$ \\
\hline A5 & ácido-base bu & & & & & & & & & & & & & & & & & & $k_{A, B b u}\left(S_{b u}-\left(K_{a, b u}+S_{u^{+}}\right)-k_{a, b u} S_{b u}\right.$ \\
\hline $\mathbf{A 6}$ & ácido-base pro & & & & & & & & & & & & & & & & & & $k_{A, B p r o}\left(S_{p r o}-\left(K_{a, p r o}+S_{H^{+}}\right)-k_{a, p r o} S_{p r o}\right.$ \\
\hline A7 & ácido-base ac & & & & & & & & & & & & & & & & & & $k_{A, B a c}\left(S_{a c}-\left(K_{a, a c}+S_{H^{+}}\right)-k_{a, a c} S_{a c}\right.$ \\
\hline $\mathbf{A 1 0}$ & ácido-base CI & & & & & & & & & & & & & & & & & & $k_{A, B c o 2}\left(S_{h c o 3}-\left(K_{a, c o 2}+S_{H^{+}}\right)-k_{a, c o 2} S_{I C}\right.$ \\
\hline A11 & ácido-base NI & 1 & -1 & & & & & & & & & & & & & & & & $k_{A, B I N}\left(S_{n h 3}-\left(K_{a, I N}+S_{H^{+}}\right)-k_{a, I N} S_{I N}\right.$ \\
\hline & $\begin{array}{l}\text { unidades: } \\
* \text { kgDQO.m }{ }^{-3} \\
* * \mathrm{k}-\mathrm{mol} \cdot \mathrm{m}^{-3}\end{array}$ & 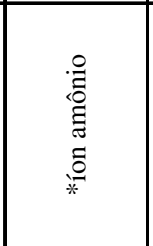 & 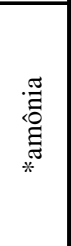 & 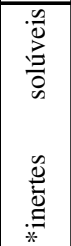 & $\begin{array}{l}\text { ? } \\
0 \\
0 \\
0 \\
\vdots \\
0 \\
0 \\
*\end{array}$ & 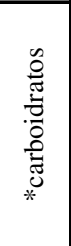 & 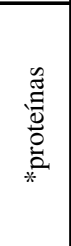 & $\frac{\tilde{0}}{0}$ & 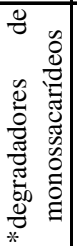 & 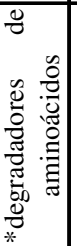 & 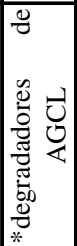 & 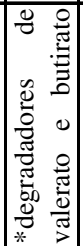 & 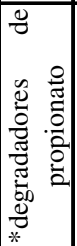 & 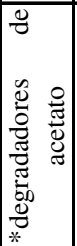 & 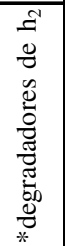 & 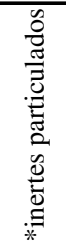 & 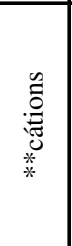 & $\begin{array}{l}\stackrel{0}{0} \\
\stackrel{\Xi}{*} \\
* \\
*\end{array}$ & $\begin{array}{l}I_{5,6}=I_{p H, a a} \cdot I_{I N, \lim } \\
I_{7}=I_{p H, a a} \cdot I_{I N, \lim } \cdot I_{h 2, f a} \\
I_{8,9}=I_{p H, a a} \cdot I_{I N, \lim } \cdot I_{h 2, c 4} \\
I_{10}=I_{p H, a a} \cdot I_{I N, \lim } \cdot I_{h 2, p r o} \\
I_{11}=I_{p H, a c} \cdot I_{I N, \lim } \cdot I_{n h 3} \\
I_{12}=I_{p H, h 2} \cdot I_{I N, \lim }\end{array}$ \\
\hline
\end{tabular}




\subsubsection{CÁLCULO DAS DERIVADAS}

O não acúmulo de biomassa pelo sistema e a igualdade entre os tempos de detenção hidráulica e de retenção celular foram considerações adotadas no modelo ADM1.

A Equação 8 apresenta o cálculo das variáveis de estado que indica volume líquido constante no reator.

$\frac{d S_{l i q, i}}{d t}=\frac{q S_{i n, i}}{V_{l i q}}-\frac{q S_{l i q, i}}{V_{l i q}}+\sum_{j=1-19} \rho_{i} v_{i j}$

\section{Equação 8}

em que: $\sum_{j=1-19} \rho_{i} v_{i j}$ corresponde a soma das taxas específicas cinéticas para processo $j$, multiplicado pelo coeficiente estequiométrico $v_{i, j}$ (Tabela 11 e Tabela 12); $V_{l i q}$ corresponde ao volume líquido do reator, ${ }^{q}$ corresponde a vazão afluente e efluente do reator; $S_{i n, i}$ corresponde a concentração afluente do material solúvel (ou $X_{i n, i}$ corresponde a concentração afluente do material particulado) e $S_{l i q, i}$ corresponde a concentração do material solúvel (ou $X_{l i q, i}$ corresponde a concentração do material particulado).

\subsubsection{VARIÁVEIS DE ESTADO DOS GASES}

As variáveis de estado dos gases foram contempladas no sistema para evitar a adição de outro reator para o gás na estrutura matricial do ADM1, que poderia dificultar o desenvolvimento do modelo.

As três variáveis adicionais de estado dos gases foram calculadas de acordo com as variáveis algébricas, vazão de gás e taxa de transferência gasosa.

A composição do biogás foi descrita por pressões parciais de metano $\left(p_{g a s, C H_{4}}\right)$, dióxido de carbono $\left(p_{g a s, C O_{2}}\right)$ e hidrogênio $\left(p_{g a s, H_{2}}\right)$, assim como por pressão de vapor de água $\left(p_{g a s, H_{2} O}\right)$. 


\subsubsection{EQUILÍBRIO DO PAR ÁCIDO/BASE}

As taxas de ácido/base são aplicadas para as equações diferenciais de ácidos graxos voláteis e carbono inorgânico como apresentado pelas Equações 9 e 10.

$$
\begin{aligned}
& \frac{d S_{l i q, i}}{d t}=\frac{q S_{i n, i}}{V_{l i q}}-\frac{q S_{l i q, i}}{V_{l i q}}+\rho_{A / B, i} \\
& \mathrm{e} \\
& \frac{d S_{l i q, i-}}{d t}=\frac{q S_{i n, i-}}{V_{l i q}}-\frac{q S_{l i q, i-}}{V_{l i q}}+\sum_{j=1-19} \rho_{j} v_{i, j}-\rho_{A / B, i}
\end{aligned}
$$

\section{Equação 9}

\section{Equação 10}

em que: i e i- representam as formas livre e iônica para os ácidos orgânicos e bicarbonato, respectivamente.

Por outro lado, o equilíbrio do par ácido/base do nitrogênio inorgânico é aplicado diferentemente. $\mathrm{O}$ termo da equação referente a taxa bioquímica $\sum_{j=1-19} \rho_{i} v_{i j}$ é aplicado ao íon amônio ao invés da amônia.

O uso dessa configuração foi motivado pela percepção que é mais apropriado aplicar o termo de equação de taxa para a forma dominante quantitativamente das variáveis de estado separadas, do que para a forma que representa apenas uma pequena parcela do respectivo componente. Assume-se que esta consideração acarreta menor número possível de problemas numéricos. A comprovação dessa consideração baseou-se em inúmeros testes, onde grande acuracidade foi alcançada pelos autores com simulações dessa condição particular.

\subsubsection{TESTES DE CONSISTÊNCIA}

Os balanços de massa para carbono e nitrogênio foram realizados adotando coeficientes estequiométricos e parâmetros sugeridos por Batstone et al. (2002a,b). Algumas modificações foram feitas para reduzir ou eliminar as discrepâncias encontradas nos balanços desses compostos. 


\subsubsection{BALANÇO DE DEMANDA QUÍMICA DE OXIGÊNIO (DQO)}

O balanço de DQO está implícito na matriz de equação de taxa. Nenhum ajuste ou produto a partir de substrato é necessário e assim nenhum balanço interno foi calculado.

\subsubsection{BALANÇO DE CARBONO}

O coeficiente de taxa para carbono inorgânico é expresso como termo de balanço. O termo é originalmente aplicado para consumo de açúcares, aminoácidos, propionato, acetato e hidrogênio uma vez que o carbono inorgânico pode ser fonte de carbono (anabolismo) ou produto desses processos (catabolismo). Devido à aplicação do modelo como sistema de equações diferenciais ordinárias (EDO) com maior número de variáveis de estado, o termo foi estendido com variáveis de estado adicionais (Equação 11).

$$
v_{15, j}=-\sum_{i=1-13,16-30} C_{i} v_{i, j}
$$

\section{Equação 11}

em que: $C_{i}$ corresponde ao conteúdo de carbono (mol C.DQO $\left.{ }^{-1}\right)$ do componente i e $v_{15, j}$ corresponde ao coeficiente estequiométrico do carbono inorgânico para o processo $\mathrm{j}$.

Além disso, o termo de balanço do carbono inorgânico para os processos de decaimento foi introduzido. As checagens iniciais de balanço para o carbono revelaram que a parcela de carbono inorgânico liberada devido ao decaimento celular é "perdida" no sistema. O ciclo do carbono "fecha" quando é considerado que a biomassa "morta" permanece como composto particulado no sistema, o qual é então parcialmente desintegrado em material particulado mais simples e consequientemente hidrolisado em substrato solúvel.

Contudo, o conteúdo de carbono presente na biomassa e nos compostos particulados na alimentação difere significantemente. Para resolver essa discrepância foi introduzido o termo da Equação 12 que substitui o carbono inorgânico liberado no decaimento celular para o estado de carbono inorgânico dissolvido.

$$
v_{15, j}=-\sum_{i=19,23-29} C_{i} v_{i, j}
$$

Equação 12 


\subsubsection{BALANÇO DE NITROGÊNIO}

Como há diferença entre a concentração de nitrogênio presente na biomassa e no afluente do sistema, o termo de balanço foi usado para "fechar" o balanço de nitrogênio o qual relaciona as "perdas" de nitrogênio com a concentração de nitrogênio inorgânico. A relação que corrige a diferença entre as concentrações de nitrogênio presentes na biomassa e no composto particulado é representada na Equação 13.

$$
v_{16, j}=-\sum_{i=19,23-29} N_{i} v_{i, j}
$$

\section{Equação 13}

em que: ${ }^{N_{i}}$ corresponde ao conteúdo de nitrogênio (mol N.DQO ${ }^{-1}$ ) do componente i $\mathrm{e}^{v_{16, j}}$ corresponde ao coeficiente estequiométrico do nitrogênio inorgânico para o processo $\mathrm{j}$.

\subsubsection{APLICAÇÃo}

A aplicação do modelo ADM1 foi desenvolvida com o uso da ferramenta computacional Matlab/Simulink e o conjunto de parâmetros cinéticos e estequiométricos reportados por Batstone et al. (2002a,b). As simulações foram realizadas para verificar a acuracidade numérica do modelo para um conjunto de dados de entrada constante.

As condições operacionais, as características do reator, os dados de entrada e os conjuntos de parâmetros foram precisamente os mesmos nas simulações. A resolução dos algoritmos nas simulações do sistema foi feita pelo método de RungeKutta de $4^{\mathrm{a}}$ ordem com a função solver ODE 15s e passo variável baseado em fórmulas de diferenciação numérica.

\subsubsection{ESTIMATIVA DE PARÂMETROS}

Os valores iniciais dos parâmetros foram obtidos dos resultados experimentais de operação do reator UASB e de dados reportados por Batstone et al. (2002a,b). 
Os coeficientes estequiométricos presentes na matriz de equações de taxa foram obtidos no Scientific and Technical Report no. 13 (BATSTONE et al., 2002a,b). As concentrações de carbono e de nitrogênio dos componentes do sistema foram recalculadas após a aplicação dos termos de balanço na matriz de equações de taxa com o objetivo de fechar o balanço de carbono e nitrogênio.

Os parâmetros físico-químicos, tais como coeficientes de equilíbrio e constantes, foram obtidos do Scientific and Technical Report no. 13 (BATSTONE et al., 2002a,b).

Os parâmetros cinéticos foram considerados constantes por apresentarem variabilidade limitada em sistemas anaeróbios (BATSTONE, 2000). Muitos parâmetros cinéticos reportados no Scientific and Technical Report no. 13 (BATSTONE et al., 2002a,b) foram revisados e comparados com valores reportados na literatura por Batstone $(2000)^{6}$, Costello $(1989)^{7}$, Romli (1995) $)^{8}$ e Ramsay (1997) ${ }^{9}$ apud Batstone et al. (2002a). Valores com pequena sensibilidade foram preferencialmente retirados desses estudos, para reduzir o grau de liberdade que dificultaria a estimativa de um conjunto de parâmetros.

Em sistemas de pequena escala é aceito considerar os valores dos parâmetros físicos, tais como $k_{L} a$ e pressão total de gás no headspace. Assim, valores idênticos foram adotados para o parâmetro $k_{L} a$ para os três gases e para constante de pressão do gás no headspace.

Esse modelo apresenta algumas limitações devido à quantidade de variáveis de entrada que deve ser conhecida, tais como, parâmetros cinéticos de crescimento celular e consumo de substrato, constantes de inibição, concentração de proteínas, carboidratos e lipídeos, concentrações de ácidos graxos voláteis, produção gasosa, dentre outras.

\footnotetext{
${ }^{6}$ Batstone, D. (2000). High-rate Anaerobic Treatment of Complex Wastewater. PhD thesis, University of Queensland, Brisbane.

${ }^{7}$ Costello, D.J., Greenfield, P.F., Lee, P.L. (1991). Dynamic modeling of a single-stage highrate anaerobic reactor. I. Model development. Water Research, n.25, p.859-871.

${ }^{8}$ Romli, M., Keller, J., Lee, P.L., Greenfield, P.F. (1995). Model prediction and verification of a two-stage high-rate anaerobic wastewater treatment system subjected to shock loads. Process Saf. Environ. Protect., n.73, p.151-154.

9 Ramsay, I.R. (1997). Modelling and Control of High-Rate Anaerobic Wastewater Treatment Systems. PhD thesis, University of Queensland, Brisbane.
} 


\subsubsection{APLICAÇÃO DOS DADOS EXPERIMENTAIS NO MODELO ADM1}

O modelo ADM1 foi aplicado como um conjunto de equações diferenciais ordinárias, as quais foram resolvidas numericamente pela função solver ODE $15 \mathrm{~s}$ da ferramenta computacional Matlab/Simulink (versão 6.5). O método aplicado para resolução das equações diferenciais ordinárias foi o Método de Runge-Kutta de $4^{\mathrm{a}}$ ordem.

A Figura 7 apresenta o arquivo.m correspondente à representação visual da resolução do modelo ADM1 no Matlab/Simulink.

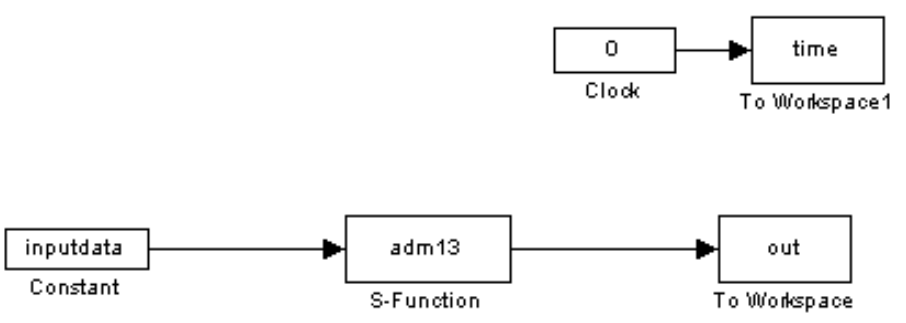

Figura 7. Representação visual em Matlab/Simulink do modelo ADM1

\subsubsection{PARÂMETROS DE SIMULAÇÃO}

Os parâmetros adotados para as simulações mantiveram-se constantes e iguais a: tempo de simulação variável, iniciando de 0 (tempo inicial) até 370 dias (tempo total de operação do sistema); tipo de resolução (solver) das equações diferenciais ordinárias (EDO) com passo variável e função ODE15s; tamanho do passo máximo $=1$; tamanho do passo mínimo $=$ automático (modelo decide qual o melhor tamanho do passo); valor do passo inicial = automático (modelo decide qual o melhor tamanho do passo).

Como o modelo é sensível à tolerância numérica usada pelo tipo de resolução (solver), os valores de acuracidade absoluta e relativa adotados foram iguais a $1 \times 10^{-6}$. Esse tipo de solver escolhido leva em torno de aproximadamente $15 \mathrm{~s}$ para resolver as simulações em um computador Pentium 4 com 448 MB de memória RAM. 


\subsubsection{INPUTDATA}

$\mathrm{O}$ arquivo de função inputdata.m corresponde ao arquivo do Matlab com os dados de entrada para a primeira etapa de operação do reator UASB, ou seja, operação com vazão média afluente e tempo de detenção hidráulica constantes. Esse arquivo contém 27 variáveis de estado de concentração.

Os dados de entrada utilizados nesse arquivo correspondem aos resultados experimentais obtidos com operação do reator UASB, com unidades s convertidas de acordo com àquelas exigidas pelo modelo ADM1. A Figura 8 apresenta as concentrações adotadas para os dados de entrada do modelo ADM1.

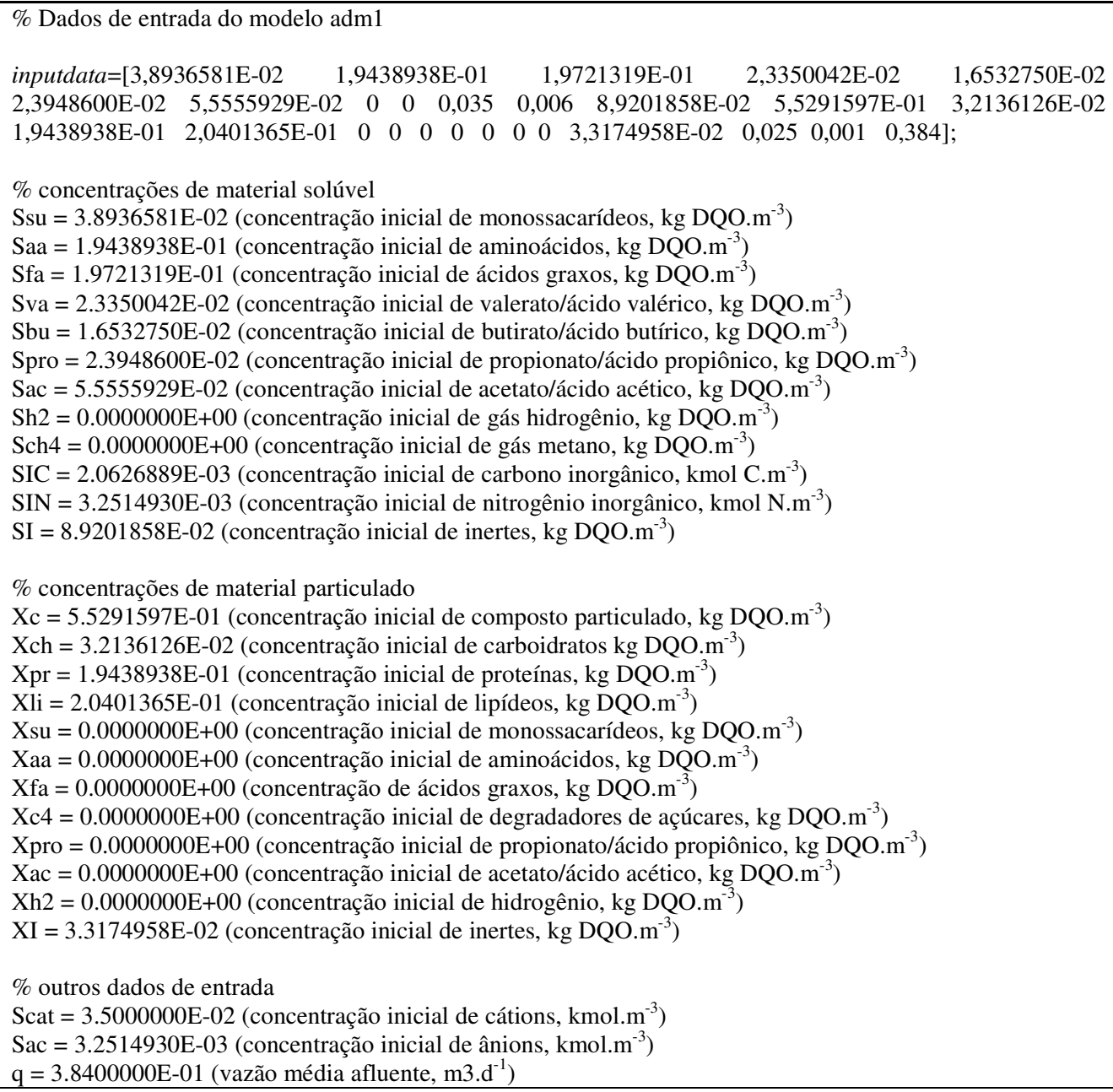

Figura 8. Dados de entrada do modelo ADM1 


\subsubsection{S-FUNCTION - ADM13}

$\mathrm{O}$ arquivo do tipo m (extensão do Matlab) de função $\mathrm{S}$ corresponde ao arquivo que contém todas as equações diferenciais ordinárias (EDO) responsáveis pelo processo de digestão.

O APÊNDICE 8.2 apresenta as equações de taxas do processo bioquímico (Equações 15 a 32).

\subsection{MODELO MATEMÁTICO SIMPLIFICADO APRIMORADO (MMS)}

Carvalho (2002) desenvolveu um modelo matemático simplificado para verificar eventuais amortecimentos e atrasos na resposta de reator UASB quando submetido a variações cíclicas diárias de cargas orgânicas e hidráulicas.

Nesse modelo o reator UASB foi dividido em apenas dois compartimentos distintos, considerados isotérmicos. O primeiro compartimento correspondia à base do manto de lodo com alta concentração de biomassa e o segundo compartimento correspondia à camada superior do leito de lodo com menor densidade de biomassa. Não havia diferença no equacionamento dos dois compartimentos, apenas alterações nos coeficientes cinéticos aplicados a cada um deles.

O comportamento hidrodinâmico de mistura completa foi adotado nesse modelo por ser comumente a primeira consideração adotada no desenvolvimento de equações de balanço de massa e pela simplicidade da resolução do equacionamento quando comparado ao equacionamento do balanço de massa para modelo hidrodinâmico tipo tubular ideal.

Os dados de entrada aplicados para realização das simulações no modelo foram: DQO afluente de $500 \mathrm{mg} . \mathrm{L}^{-1}$, vazão média afluente de $1,32 \mathrm{~L} \cdot \mathrm{h}^{-1}$, variação de vazão de 50\% e volume do reator de 10,5 L, de acordo com Batista (2000).

Os parâmetros cinéticos intrínsecos do modelo de Monod $\mathrm{q}_{\text {máx }}$ igual a 0,005 mgDQO. $\mathrm{mg}^{-1} \mathrm{SSV} . \mathrm{h}^{-1}, \mathrm{~K}_{\mathrm{s}}$ igual a $82 \mathrm{mg} . \mathrm{L}^{-1}$ foram obtidos de Paula Jr. e Foresti (1992) para degradação de matéria orgânica (DQO), com emprego de equacionamentos empíricos encontrados na literatura. A princípio, não foram considerados ajustes nos coeficientes estequiométricos. 
Os efeitos de transferência de massa foram desprezados quando havia mudança na velocidade de escoamento.

Carvalho (2002) verificou que o modelo indicou a capacidade de amortecimento do reator UASB às sobrecargas impostas após certo período de tempo, mesmo quando submetido à variação da carga hidráulica e com baixa eficiência na remoção da matéria orgânica.

Como um dos objetivos da tese de doutoramento é validar o modelo matemático simplificado, o modelo desenvolvido por Carvalho (2002) foi modificado e aprimorado. O reator foi dividido em quatro compartimentos em série, com os três primeiros empregados para reação propriamente dita e o quarto compartimento como um simples separador proporcional da biomassa que, em parte, retorna para o segundo compartimento (Figura 9.a.). Esse último compartimento, apesar de possuir volume, não acumula biomassa ou substrato. Essa configuração foi adotada por simplificar o equacionamento matemático.

O modelo é baseado no regime de escoamento contínuo de mistura completa em reatores em série com cinética de reação de primeira ordem para consumo de substrato e cinética de Monod para crescimento da biomassa, conforme exemplos da literatura (BATSTONE et al., 1997 e CASTILLO et al., 1999).

O retorno para o segundo compartimento foi escolhido para simular o escoamento do lodo que ocorre em um reator UASB. Nesses reatores, parte do lodo que eventualmente atinge o separador de sólidos é relativamente denso e flutua apenas por ter sido aderido a uma bolha de biogás. Quando essa bolha se desprende, o lodo sedimenta, atravessa a camada 3 formada por um manto pouco denso e atinge a camada 2 onde se localiza o leito de lodo mais denso. Dificilmente o lodo que flutuou chega a atingir, em seu retorno, a primeira camada, bastante adensada.

Do ponto de vista da verificação que se pretendia fazer, efeito da cinética da reação, essa configuração, além de eliminar regiões mortas e recirculações hidráulicas, proporciona um fator de segurança. Esses fenômenos hidráulicos, ao contrário dos curto-circuitos, provocam, por si, algum amortecimento no tempo de resposta do reator e, nesse caso, interessava conhecer qual era o amortecimento inerente às reações químicas e não aquele proporcionado pelo escoamento no reator (PIRES et al., 2002). 
A resolução numérica das equações diferenciais ordinárias (EDO), correspondentes aos balanços de massa, foi realizada pelo método de Runge-Kutta de $4^{\mathrm{a}}$ ordem com aplicação do programa computacional Matlab. Os resultados foram apresentados na forma de gráficos que mostravam a variação de DQO efluente ao longo do tempo $(\mathrm{t})$.

No balanço simplificado foram considerados apenas dois componentes, substrato e biomassa ativa. Assim, conceitualmente há apenas um processo envolvido, a conversão do substrato em biomassa ativa e a remoção da matéria orgânica (Figura 9.b.). O substrato é expresso como demanda química de oxigênio (DQO) e a biomassa ativa como concentração de sólidos suspensos voláteis (SSV). Com essas simplificações, os termos de consumo de substrato e produção de biomassa ativa puderam ser modelados conforme procedimentos bem definidos, descritos, por exemplo, em Olsson e Newell (1999) ou Dochain e Vanrolleghem (2001).

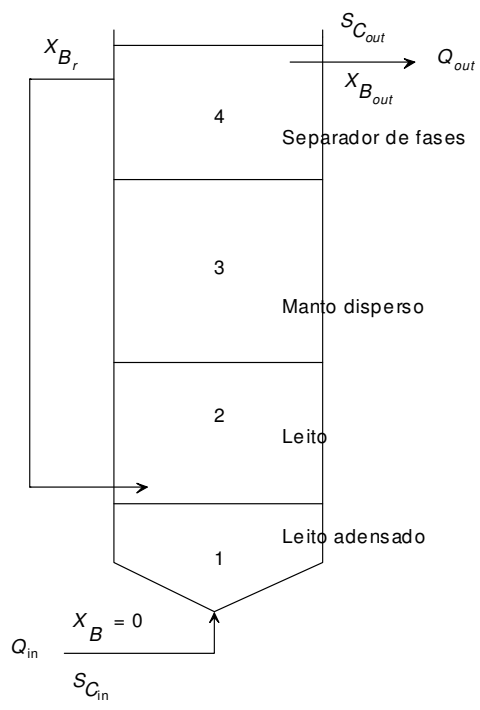

(a)

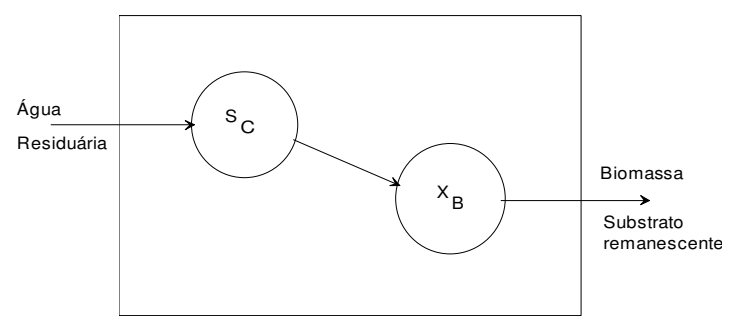

Figura 9. Esquema conceitual do reator UASB (a) e das conversões do substrato (b) para desenvolvimento do modelo matemático $\left(S_{C}\right.$ é a concentração de substrato solúvel e $X_{B}$ a concentração da biomassa ativa). Fonte: adaptado de Dochain e Vanrolleghem (2001)

Para simular a variação horária da vazão afluente considerou-se que essa variável possui comportamento senoidal, com período de $24 \mathrm{~h}$ e estabeleceu-se a amplitude como uma das variáveis estudadas (Equação 14). Considerou-se que o 
reator possui volume constante. Estabelecidas as condições de trabalho foi possível deduzir o balanço de massa para cada um dos componentes de interesse.

Dessa forma, o balanço hidráulico é o mesmo para os quatro compartimentos e se resume a:

$$
Q_{\text {in }}=Q_{\text {out }}=\bar{Q}(1+\alpha \operatorname{sen} \omega t)
$$

\section{Equação 14}

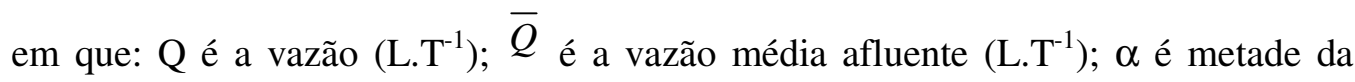
amplitude decimal relativa da variação da vazão, que pode assumir valores entre zero e um (adimensional); $\omega$ é a frequiência da variação da vazão $\left(\mathrm{T}^{-1}\right)$. Os índices in e out indicam os dados de entrada e os dados de saída do reator, respectivamente.

A Tabela 13 apresenta as equações de balanço de massa para o substrato e a biomassa dos compartimentos 1 a 4 .

Tabela 13. Equações de balanço de massa dos compartimentos 1 a 4

\begin{tabular}{|c|c|c|}
\hline substrato & & Biomassa \\
\hline \multicolumn{3}{|c|}{ compartimentos 1 e 3} \\
\hline$\frac{d S_{C 1}}{d t}=\frac{Q}{V_{1}}\left(S_{C i n}-S_{C 1}\right)-\frac{1}{Y_{B}} \mu_{\text {max } 1}$ & $\left(\frac{\mathrm{S}_{\mathrm{C} 1}}{\mathrm{~K}_{\mathrm{S} 1}+S_{\mathrm{C} 1}}\right) \mathrm{X}_{\mathrm{B} 1}$ & $\frac{\mathrm{dX}_{\mathrm{B} 1}}{\mathrm{dt}}=-\frac{\mathrm{Q}}{\mathrm{V}_{1}} \mathrm{X}_{\mathrm{B} 1}+\mu_{\text {máx } 1}\left(\frac{\mathrm{S}_{\mathrm{C} 1}}{\mathrm{~K}_{\mathrm{S} 1}+\mathrm{S}_{\mathrm{C} 1}}\right) \mathrm{X}_{\mathrm{B} 1}$ \\
\hline$\frac{d S_{C 3}}{d t}=\frac{Q}{V_{3}}\left(S_{C 2}-S_{C 3}\right)-\frac{1}{Y_{B}} \mu_{\text {máx }}$ & $\left(\frac{\mathrm{S}_{\mathrm{C} 3}}{\mathrm{~K}_{\mathrm{S} 3}+S_{\mathrm{C} 3}}\right) \mathrm{X}_{\mathrm{B} 3}$ & $\frac{d X_{B 3}}{d t}=\frac{Q}{V_{3}}\left(X_{B 2}-X_{B 3}\right)+\mu_{\text {máx3 }}\left(\frac{\mathrm{S}_{\mathrm{C} 3}}{\mathrm{~K}_{\mathrm{S} 3}+S_{C 3}}\right) \mathrm{X}_{\mathrm{B} 3}$ \\
\hline \multicolumn{3}{|c|}{ compartimento 2} \\
\hline$\frac{d S_{C 2}}{d t}=\frac{Q}{V_{2}}\left(S_{C 1}-S_{C 2}\right)-\frac{1}{Y_{B}} \mu_{\text {máx }}$ & $\left(\frac{\mathrm{S}_{\mathrm{C} 2}}{\mathrm{~K}_{\mathrm{S} 2}+S_{C 2}}\right) \mathrm{X}_{\mathrm{B} 2}$ & $\frac{d X_{B 2}}{d t}=\frac{Q}{V_{2}}\left(X_{B 1}-X_{B 2}\right)+C_{S} Q \frac{X_{B 3}}{V_{4}}+\mu_{\max 2}\left(\frac{\mathrm{S}_{\mathrm{C} 2}}{\mathrm{~K}_{\mathrm{S} 2}+S_{C 2}}\right) \mathrm{X}_{\mathrm{B} 2}$ \\
\hline \multicolumn{3}{|c|}{ compartimento 4} \\
\hline $\mathrm{S}_{\mathrm{C}_{\text {out }}}=\mathrm{S}_{\mathrm{C}_{4}}=\mathrm{S}_{\mathrm{C}}$ & & $X_{B_{4}}=X_{B_{3}}\left(1-C_{S}\right)$ \\
\hline
\end{tabular}

\section{Fonte: adaptado de Carvalho e Pires (2002)}

Com o objetivo de verificar os efeitos do comportamento senoidal da vazão (Equação 14), sobre a remoção de DQO modelou-se o experimento relatado por Pires et al. (2001). Sendo assim, também foi possível averiguar se os resultados 
experimentais reportados foram influenciados por efeitos da escala do reator, conforme suposições dos autores. Para os parâmetros cinéticos necessários ao modelo, foram utilizados, como valores iniciais, aqueles determinados por Paula Jr. e Foresti (1992), que operaram reator UASB com características físicas similares as do reator empregado por Pires et al. (2001).

Como parâmetro de calibração do modelo matemático foi empregado o valor de $\mu_{\text {máx }}$, uma vez que estudos anteriores mostraram ser esse o parâmetro de maior influência sobre o resultado. Seu valor foi ajustado para que a simulação matemática ficasse próxima dos resultados experimentais obtidos anteriormente. Os valores numéricos dos parâmetros do modelo são apresentados na Tabela 14. Nessas simulações todos os parâmetros cinéticos e estequiométricos foram considerados constantes ao longo do reator, uma vez que não foram coletados dados experimentais por Pires et al. (2001) que permitissem qualquer suposição quanto à suas variações espaciais ou temporais.

Tabela 14. Simbologia empregada, valores numéricos dos parâmetros do modelo e unidades

\begin{tabular}{|c|c|c|c|}
\hline Símbolo & Significado & Valor & Unidade \\
\hline$\alpha$ & Metade da amplitude da vazão & $0 ; 0,25$ e 0,5 & - \\
\hline $\mathrm{C}_{\mathrm{S}}$ & Coeficiente de separação (separador de fases) & 0,8 & - \\
\hline $\mathrm{K}_{\mathrm{S}}^{1}$ & Constante de meia saturação para o substrato & 82 & mgDQO.L $\mathrm{L}^{-1}$ \\
\hline$Q_{\text {média }}$ & Vazão média & 1,31 & L.h $\mathrm{h}^{-1}$ \\
\hline$\mu_{\max }^{1}$ & $\begin{array}{l}\text { Velocidade máxima de crescimento de } \\
\text { biomassa }\end{array}$ & $\begin{array}{c}0,001^{2} \\
0,0005^{3}\end{array}$ & L.h ${ }^{-1}$ \\
\hline$S_{C}$ & Concentração de substrato afluente & 500 e 1.000 & mgDQO.L $\mathrm{L}^{-1}$ \\
\hline$V_{1}$ & Volume do compartimento 1 (leito adensado) & 1,5 & $\mathrm{~L}$ \\
\hline$V_{2}$ & Volume do compartimento 2 (leito) & 2,5 & $\mathrm{~L}$ \\
\hline$V_{3}$ & Volume do compartimento 3 (manto disperso) & 3,0 & $\mathrm{~L}$ \\
\hline$V_{4}$ & $\begin{array}{l}\text { Volume do compartimento } 4 \text { (separador de } \\
\text { fases) }\end{array}$ & 3,5 & $\mathrm{~L}$ \\
\hline $\mathrm{X}_{\mathrm{B}}$ & Concentração inicial de biomassa ativa & 30 & $\operatorname{mgSSV} . \mathrm{L}^{-1}$ \\
\hline $\mathrm{Y}_{\mathrm{B}}$ & $\begin{array}{c}\text { Coeficiente de conversão de substrato em } \\
\text { biomassa }\end{array}$ & 0,15 & $\operatorname{mgSSV} .(\mathrm{mgDQO})^{-1}$ \\
\hline
\end{tabular}

${ }^{1}$ valores obtidos de Paula Jr. e Foresti (1992); ${ }^{2}$ para $S_{C}$ afluente de $500 \mathrm{mgDQO} . \mathrm{L}^{-1}$; ${ }^{3}$ para $S_{C}$ afluente de $1000 \mathrm{mgDQO} . \mathrm{L}^{-1}$.

Como um dos objetivos da tese de doutoramento era validar o modelo matemático simplificado, mais modificações foram realizadas com o objetivo de aprimorar o modelo MMS. 
A primeira modificação do modelo foi em relação ao termo referente ao comportamento hidrodinâmico. Com a realização dos ensaios hidrodinâmicos em cada etapa de operação do reator UASB foi possível aplicar os resultados obtidos com o ajuste dos modelos teóricos uniparamétricos no termo referente ao comportamento hidrodinâmico do modelo. Novamente optou-se por adotar o regime de escoamento contínuo de mistura completa em reatores em série, devido a maior simplicidade no equacionamento e na resolução matemática desse modelo quando comparado aos modelos de pequena e grande dispersão.

No desenvolvimento das equações de balanço de massa do modelo MMS, o número de equações variava em função do número de reatores de mistura completa em série (N-CSTR) obtidos nos ensaios hidrodinâmicos para cada etapa de operação do reator. Vale ressaltar que foi mantida a consideração do último compartimento como separador proporcional de biomassa no MMS em todas as configurações obtidas nos ensaios hidrodinâmicos, sem acúmulo de biomassa ou substrato.

Outra modificação do modelo MMS é a consideração do modelo cinético de primeira ordem para consumo de substrato e crescimento microbiano.

A Tabela 15 apresenta as equações de balanço de massa para o substrato e a biomassa dos compartimentos 1 a 4 .

Tabela 15. Equações de balanço de massa dos compartimentos 1 a 4

\begin{tabular}{cc}
\hline substrato & biomassa \\
\hline$\frac{d S_{C 1}}{d t}=\frac{Q}{V_{1}}\left(S_{C i n}-S_{C 1}\right)-k_{1} S_{C 1}$ & $\frac{d X_{B 1}}{d t}=-\frac{Q}{V_{1}} X_{B 1}+Y_{B} k_{1} S_{C 1}$ \\
$\frac{d S_{C 3}}{d t}=\frac{Q}{V_{3}}\left(S_{C 2}-S_{C 3}\right)-k_{3} S_{C 3}$ & $\frac{d X_{B 3}}{d t}=\frac{Q}{V_{3}}\left(X_{B 2}-X_{B 3}\right)+Y_{B} k_{3} S_{C 3}$ \\
\hline$\frac{d S_{C 2}}{d t}=\frac{Q}{V_{2}}\left(S_{C 1}-S_{C 2}\right)-k_{2} S_{C 2}$ & compartimento 2 \\
\hline $\mathrm{S}_{\mathrm{C}_{\text {out }}}=\mathrm{S}_{\mathrm{C}_{4}}=\mathrm{S}_{\mathrm{C}_{3}}$ & compartimento 4 \\
\hline
\end{tabular}

No aprimoramento do MMS foi desenvolvida uma rotina computacional com o auxílio da ferramenta Matlab para calibrar o valor da constante cinética aparente de primeira ordem $\left(\mathrm{k}_{1}\right)$. Assim, foi adotada uma função objetivo $(F)$ que considera a 
minimização da soma do quadrado da diferença dos valores de DQO efluente obtidos experimentalmente com a operação do reator UASB $\left(\mathrm{DQO}_{\mathrm{e}}\right)$ e os observados nas simulações $\left(\mathrm{DQO}_{\mathrm{s}}\right)$ do MMS (Equação 15).

$$
F=\operatorname{Min} \sum(D Q O e-D Q O s)^{2}
$$

\section{Equação 15}

A Tabela 16 apresenta a simbologia, os valores numéricos dos parâmetros e unidades empregadas no aprimoramento do modelo.

Tabela 16. Simbologia empregada, valores numéricos dos parâmetros do modelo e unidades

\begin{tabular}{|c|c|c|c|}
\hline Símbolo & Significado & Valor & Unidade \\
\hline$\alpha$ & Metade da amplitude da vazão & $0 ; 40$ e 60 & $\%$ \\
\hline $\mathrm{C}_{\mathrm{S}}$ & $\begin{array}{l}\text { Coeficiente de separação (separador de } \\
\text { fases) }\end{array}$ & 0,8 & - \\
\hline $\mathrm{k}_{1}{ }^{1}$ & Constante cinética de $1^{\mathrm{a}}$ ordem & $f(F)$ & $\mathrm{h}^{-1}$ \\
\hline $\mathrm{Q}$ & Vazão média afluente & 16 & $L . h^{-1}$ \\
\hline$S_{\text {Cin }}^{2}$ & Concentração de substrato afluente & variável & $\operatorname{mgDQO} . \mathrm{L}^{-1}$ \\
\hline$S_{C n^{3}}{ }^{3}$ & Concentração de substrato efluente & variável & $\operatorname{mgDQO} . \mathrm{L}^{-1}$ \\
\hline$V_{\mathrm{n}}^{4}$ & Volume do compartimento n & variável & $\mathrm{L}$ \\
\hline$V_{\mathrm{n}+1}^{5}$ & $\begin{array}{l}\text { Volume do último compartimento } \\
\text { (separador de fases) }\end{array}$ & variável & $\mathrm{L}$ \\
\hline $\mathrm{X}_{\mathrm{B}}{ }^{6}$ & Concentração inicial de biomassa ativa & variável & $\operatorname{mgSSV} . \mathrm{L}^{-1}$ \\
\hline$Y_{B}$ & $\begin{array}{c}\text { Coeficiente de conversão de substrato em } \\
\text { biomassa }\end{array}$ & 0,15 & mgSSV.(mgDQO) $)^{-1}$ \\
\hline \multicolumn{4}{|c|}{$\begin{array}{l}\text { valores obtidos pela função de minimização } F ;{ }^{2} \text { DQO afluente obtida } \\
\text { experimentalmente nos perfis de amostragem temporal; }{ }^{3} \text { DQO efluente obtida } \\
\text { experimentalmente nos perfis de amostragem temporal; }{ }^{4} \text { volume de cada } \\
\text { compartimento variável em função do número de câmaras em série; }{ }^{5} \text { volume do } \\
\text { último compartimento variável em função do número de câmaras em séries; } \\
6 \text { concentração de SSV obtida experimentalmente nos perfis de amostragem temporal }\end{array}$} \\
\hline
\end{tabular}




\section{RESULTADOS E DISCUSSÃO}

Esse capítulo descreve os resultados e discussões parciais mencionados no capítulo Material e Métodos para cada etapa de operação do reator UASB. Os resultados e discussões correspondem a 372 dias de operação do reator UASB e são divididos em: parte experimental e parte teórica para facilitar a compreensão da metodologia. A parte experimental compreendeu os seguintes itens:

- Caracterização do esgoto sanitário;

- Operação e monitoramento do reator UASB (146 L) com vazão constante - ETAPA I;

- Operação e monitoramento do reator UASB (160 L) com vazão constante - ETAPA II;

- Operação e monitoramento do reator UASB (160 L) com variação senoidal cíclica da vazão média afluente em $40 \%$ - ETAPA III;

- Operação e monitoramento do reator UASB (160 L) com variação senoidal cíclica da vazão média afluente em 60\% - ETAPA IV;

- Ensaios hidrodinâmicos.

A parte teórica compreende as seguintes etapas:

- Análise e preparação dos resultados experimentais em cada etapa de operação dos reatores UASB de 146 L e de 160 L;

- Aplicação dos dados experimentais como variáveis (dados) de entrada nos modelos ADM1 e MMS;

- Calibração do modelo ADM1;

- Calibração e validação do modelo MMS;

É importante ressaltar que os pontos dos gráficos (tipo dispersão (XY)) apresentados nesse trabalho foram ligados por linhas suaves com o único objetivo de facilitar a visualização do comportamento das curvas. Não foram realizadas 
medições intermediárias, nem efetuados ajustes nas curvas, não havendo portanto garantia de que os valores intermediários entre dois pontos consecutivos possam ser obtidos por interpolação de valores.

Em alguns casos foram utilizados valores médios dos parâmetros monitorados, seguidos do desvio padrão. Nesse caso, considerou-se que 68,26\% dos pontos medidos estão compreendidos no intervalo citado.

\subsection{CARACTERIZAÇAO DO ESGOTO SANITÁRIO}

Conforme discutido previamente no capítulo Material e Métodos, o esgoto sanitário utilizado na alimentação do reator UASB foi suplementado com esgoto sintético simulando esgoto real, para que fosse mantida concentração de matéria orgânica afluente em termos de DQO na faixa conhecida de $450 \mathrm{mg} . \mathrm{L}^{-1}$ a $700 \mathrm{mg} . \mathrm{L}^{-1}$.

Daltro (1988), Povinelli (1994) e Nour (1996) utilizaram o esgoto sanitário coletado na mesma estação elevatória de esgoto em suas pesquisas e obtiveram valores de DQO média afluente iguais a $534 \pm 65 \mathrm{mg} . \mathrm{L}^{-1}, 475 \pm 225 \mathrm{mg} . \mathrm{L}^{-1}$ e $433 \pm 112 \mathrm{mg} \cdot \mathrm{L}^{-1}$, respectivamente. É possível verificar diminuição da concentração média de matéria orgânica com o passar dos anos. Essa diminuição pode ter ocorrido devido ao aumento do número de estabelecimentos comerciais e de residências com padrão de classe média nessa região da cidade de São Carlos, que contribuíram para diluição do esgoto sanitário.

Ensaios de determinação da variação da concentração de matéria orgânica, em termos de DQO, foram realizados ao longo do mês de maio de 2003. Foi possível notar que a DQO não atingiu a concentração de 400 mg.L $\mathrm{L}^{-1}$, mesmo com o aumento da concentração de matéria orgânica afluente às 18:00h, indicando a necessidade de suplementação do esgoto bruto.

A suplementação do esgoto sanitário foi realizada com esgoto sintético, simulando esgoto real para valor médio de DQO de aproximadamente $300 \mathrm{mg}$. $\mathrm{L}^{-1}$, de acordo com metodologia proposta por Torres (1992). A Figura 10 apresenta os resultados da DQO para cada um dos componentes do esgoto sintético, proporcionais àqueles reportados por Torres (1992) para DQO média de aproximadamente $300 \mathrm{mg} \cdot \mathrm{L}^{-1}$. 


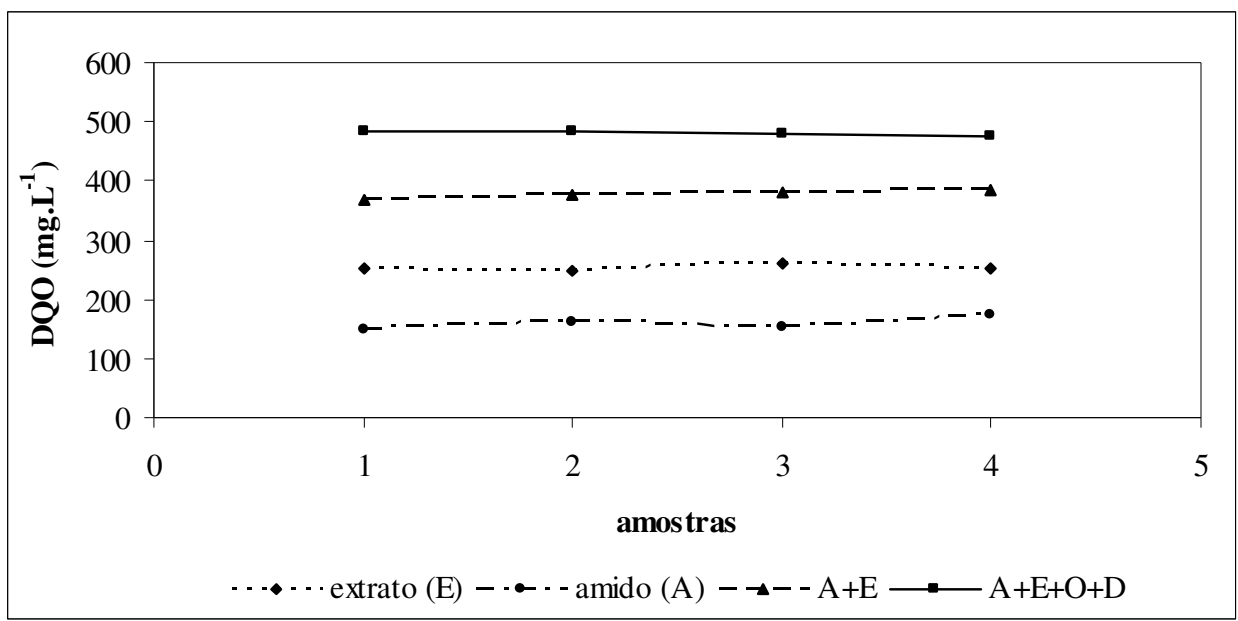

Figura 10. Valores de DQO para os componentes do substrato (500 $\left.\mathrm{mg}^{-\mathrm{L}^{-1}}\right)$, sendo: $E$ - extrato de carne em pasta; $A$ - amido de milho; $A+E$ - solução de amido de milho e extrato de carne; $\mathrm{A}+\mathrm{E}+\mathrm{O}+\mathrm{D}$ - solução de amido de milho, extrato de carne, óleo e detergente

Como o armazenamento do substrato (esgoto bruto + esgoto sintético) era feito nos tanques de equalização durante o período de operação do reator, ensaios de DQO foram realizados para verificar a degradação de matéria orgânica durante período de $24 \mathrm{~h}$.

A Figura 11 apresenta a degradação média do substrato nos tanques de armazenamento.

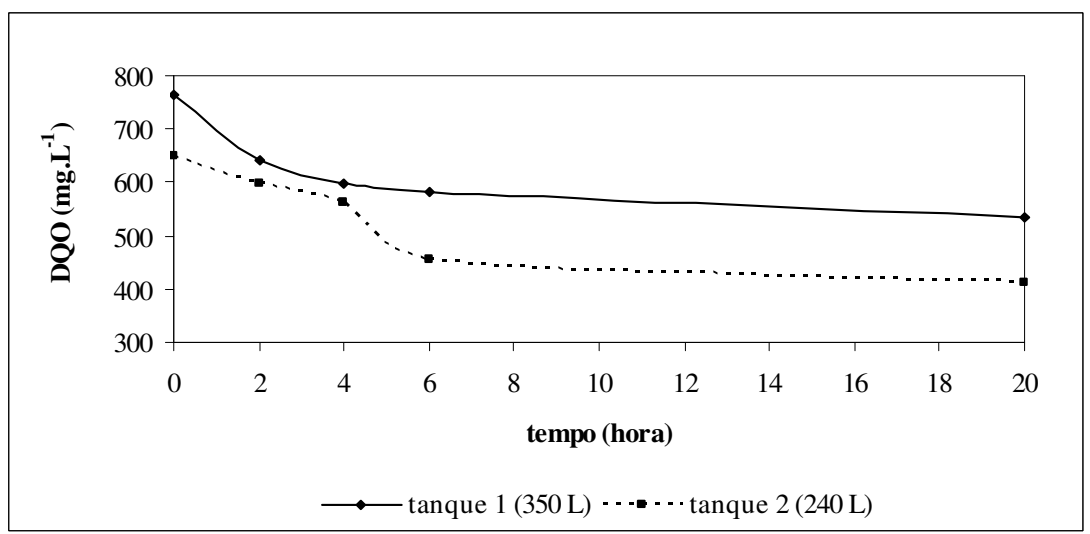

Figura 11. Perfil temporal de degradação média de DQO nos tanques de armazenamento

Pela Figura 11 é possível verificar degradação do substrato nos tanques de armazenamento ao longo de um dia, pois no primeiro tanque, a concentração de 
DQO afluente decresceu aproximadamente $30 \%$, ou seja, de 764 mg.L ${ }^{-1}$ para $580 \mathrm{mg} . \mathrm{L}^{-1}$ nas primeiras 6 horas. Nesse mesmo período de tempo, no segundo tanque, a DQO afluente decresceu aproximadamente 36\%, variando de $650 \mathrm{mg} . \mathrm{L}^{-1}$ para $457 \mathrm{mg} . \mathrm{L}^{-1}$. Após $20 \mathrm{~h}$ da suplementação, foi possível verificar decréscimo da DQO afluente para aproximadamente $534 \mathrm{mg} . \mathrm{L}^{-1}$ e $410 \mathrm{mg} . \mathrm{L}^{-1}$, no primeiro e segundo tanque, respectivamente.

A caracterização do esgoto sanitário e do substrato foi baseada nos resultados experimentais obtidos em todo o monitoramento do sistema e nas oito campanhas de amostragem de perfis temporais realizados no período de 25/10/2003 a 26/10/2004.

A Tabela 17 apresenta a caracterização do esgoto sanitário e do substrato durante o monitoramento do reator UASB.

Tabela 17. Características do esgoto sanitário e do substrato afluente ao reator UASB (monitoramento)

\begin{tabular}{|c|c|c|c|c|c|c|c|c|c|c|}
\hline \multirow[t]{2}{*}{ PARÂMETROS } & \multicolumn{5}{|c|}{ ESGOTO BRUTO } & \multicolumn{5}{|c|}{ SUBSTRATO } \\
\hline & $\mathrm{N}$ & $\bar{X}$ & DP & Min & Máx & $\mathrm{N}$ & $\bar{X}$ & DP & Min & Máx \\
\hline $\mathrm{pH}$ & 5 & 7,3 & 0,1 & 7,2 & 7,3 & 40 & 6,6 & 0,3 & 6,1 & 7,3 \\
\hline alc total $\left(\mathrm{mg} \mathrm{CaCO} 3 \cdot \mathrm{L}^{-1}\right)$ & 5 & 136 & 18 & 112 & 157 & 40 & 189 & 48 & 104 & 322 \\
\hline DQO bruta $\left(\mathrm{mg} \cdot \mathrm{L}^{-1}\right)$ & 5 & 219 & 36 & 176 & 264 & 40 & 536 & 177 & 227 & 969 \\
\hline DQO filtrada (mg.L $\left.{ }^{-1}\right)$ & 5 & 124 & 22 & 106 & 155 & 40 & 312 & 115 & 69 & 532 \\
\hline $\mathrm{ST}\left(\mathrm{mg} \cdot \mathrm{L}^{-1}\right)$ & 5 & 437 & 75 & 360 & 509 & 40 & 619 & 164 & 300 & 1088 \\
\hline STF $\left(m g \cdot L^{-1}\right)$ & 5 & 256 & 174 & 144 & 457 & 40 & 228 & 152 & 0 & 600 \\
\hline STV (mg.L $\left.L^{-1}\right)$ & 5 & 181 & 115 & 52 & 274 & 40 & 391 & 173 & 100 & 843 \\
\hline $\operatorname{SST}\left(\mathrm{mg} \cdot \mathrm{L}^{-1}\right)$ & 5 & 118 & 44 & 53 & 144 & 40 & 149 & 93 & 48 & 383 \\
\hline $\mathrm{SSF}\left(\mathrm{mg} \cdot \mathrm{L}^{-1}\right)$ & 5 & 26 & 11 & 15 & 36 & 40 & 21 & 19 & 1 & 372 \\
\hline $\mathrm{SSV}\left(\mathrm{mg} \cdot \mathrm{L}^{-1}\right)$ & 5 & 92 & 27 & 61 & 108 & 40 & 128 & 90 & 46 & 372 \\
\hline DBO bruta (mg.L $\left.\mathrm{L}^{-1}\right)$ & - & - & - & - & - & 6 & 291 & 24 & 253 & 318 \\
\hline
\end{tabular}

É possível notar na Tabela 17 que a DQO média do substrato (após suplementação) foi de $536 \pm 177 \mathrm{mg} . \mathrm{L}^{-1}$ e a DBO média foi de $291 \pm 24 \mathrm{mg} . \mathrm{L}^{-1}$, resultando um valor de 0,54 para a relação DBO/DQO. Esse valor é similar àqueles geralmente reportados na literatura para esgoto sanitário (ORHON et al., 1997; CASTILLO et al., 1999; PASSIG et al., 2000; FLORENCIO et al., 2001 e PASSIG, 2005).

A Figura 12 apresenta o fluxograma da distribuição da concentração de sólidos totais, sólidos suspensos e de sólidos dissolvidos, calculado a partir dos dados do substrato da Tabela 17. 


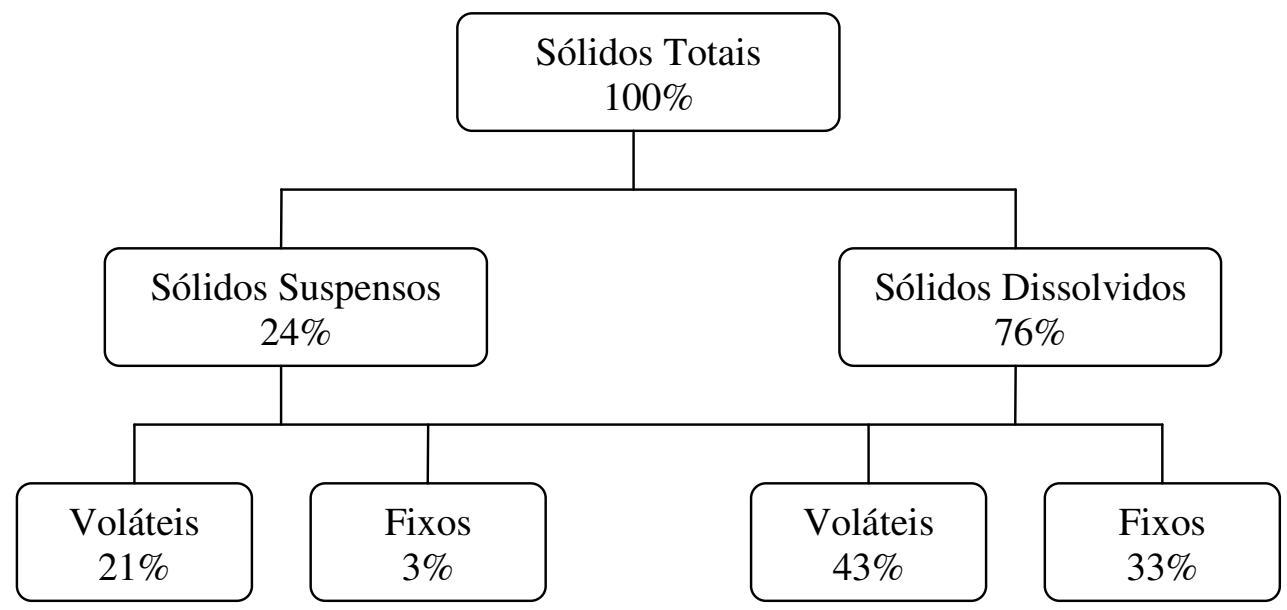

Figura 12. Fluxograma da distribuição percentual da concentração de sólidos no afluente do reator UASB

A Tabela 18 apresenta a composição típica e a classificação do esgoto doméstico quanto aos constituintes físicos e químicos de acordo com Metcalf e Eddy (2003).

Tabela 18. Composição típica do esgoto sanitário

\begin{tabular}{c|ccc}
\hline PARÂMETROS & \multicolumn{3}{|c}{ ESGOTO SANITÁRIO } \\
& Fraco & Médio & Forte \\
\hline DQO total $\left(\mathrm{mg} \cdot \mathrm{L}^{-1}\right)$ & 250 & 430 & 800 \\
DBO $\left(\mathrm{mg} \cdot \mathrm{L}^{-1}\right)$ & 110 & 190 & 350 \\
ST $\left(\mathrm{mg} \cdot \mathrm{L}^{-1}\right)$ & 390 & 720 & 1230 \\
STD $\left(\mathrm{mg} \cdot \mathrm{L}^{-1}\right)$ & 270 & 500 & 860 \\
SDF $\left(\mathrm{mg} \cdot \mathrm{L}^{-1}\right)$ & 160 & 300 & 520 \\
SDV $\left(\mathrm{mg} \cdot \mathrm{L}^{-1}\right)$ & 110 & 200 & 340 \\
SST $\left(\mathrm{mg} \cdot \mathrm{L}^{-1}\right)$ & 120 & 210 & 400 \\
SSF $\left(\mathrm{mg} \cdot \mathrm{L}^{-1}\right)$ & 25 & 50 & 85 \\
SSV $\left(\mathrm{mg} \cdot \mathrm{L}^{-1}\right)$ & 95 & 160 & 315 \\
\hline
\end{tabular}

Fonte: adaptado de Metcalf e Eddy (2003)

Ao comparar os resultados da DQO e da DBO da Tabela 18 e Tabela 17, é possível verificar que o afluente do reator UASB apresentou composição de esgoto "fraco" antes da suplementação com esgoto sintético. Porém após a suplementação, os resultados da DQO e da DBO indicaram composição de esgoto "médio", de acordo com Metcalf e Eddy (2003). 
Em relação às concentrações de ST, STV, STF, SST, SSV e de SSF, os valores obtidos indicam que o esgoto é "fraco", provavelmente devido as características, previamente citadas, do bairro contribuinte desse esgoto e ao tratamento preliminar (gradeamento, poço de sucção e tanques de equalização) pelo qual passa antes de ser usado na alimentação do reator.

A Figura 13 apresenta a caracterização do substrato nas oito campanhas de amostragem de perfis temporais realizados no período de 25/10/2003 a 26/10/2004 . As curvas representam algumas características do substrato obtidas pelas médias horárias (em função da hora do dia) das amostragens temporais do substrato do reator UASB. Podem ser observadas as variações temporais de $\mathrm{pH}$, alcalinidade a bicarbonato, DQO bruta e filtrada, concentração de sólidos totais (ST) e de sólidos suspensos totais (SST).

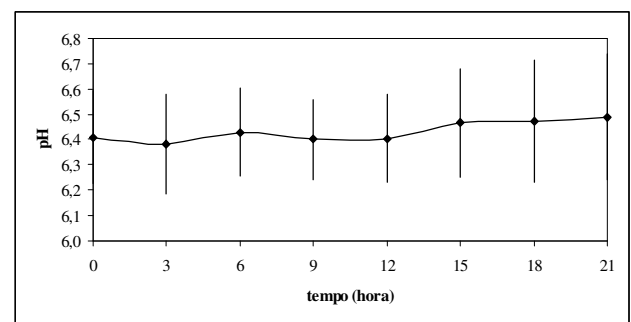

(a)

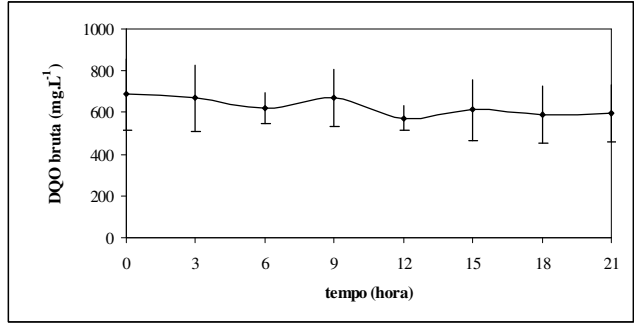

(c)

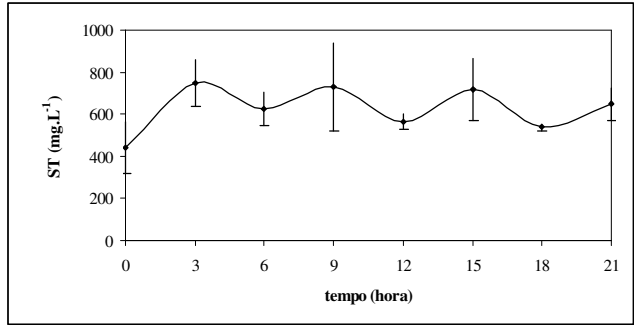

(e)

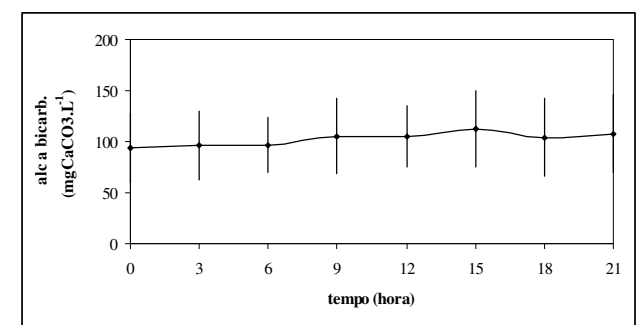

(b)

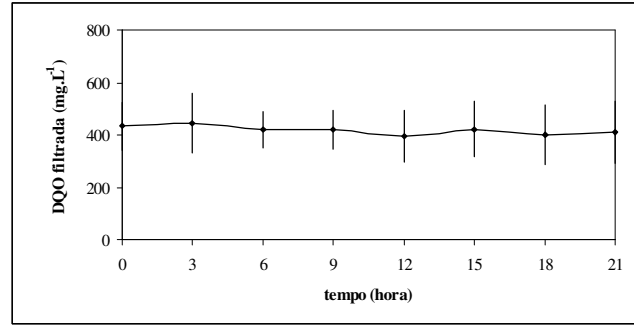

(d)

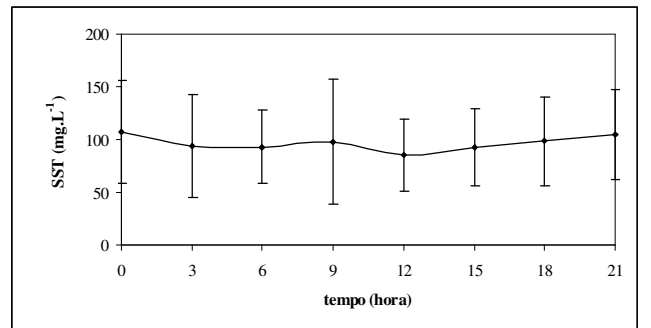

(f)

Figura 13.Caracterização do substrato (média horária) do reator UASB: a) pH, b) alcalinidade a bicarbonato, c) DQO bruta, d) DQO filtrada, e) concentração de sólidos totais, f) concentração de sólidos suspensos totais. *O tempo 0 dos gráficos corresponde às $9 \mathrm{~h}$. 
A Tabela 19 apresenta um resumo das características do substrato nas 8 campanhas de perfis temporais.

Tabela 19. Resumo das características do substrato do reator UASB (perfis temporais de amostragem - 1 a 8 )

\begin{tabular}{|c|c|c|c|c|c|}
\hline \multirow[t]{2}{*}{ PARÂMETROS } & \multicolumn{5}{|c|}{ SUBSTRATO } \\
\hline & $\mathrm{N}$ & $\bar{X}$ & DP & Min & Máx \\
\hline $\mathrm{pH}$ & 64 & 6,4 & 0,0 & 6,4 & 6,5 \\
\hline Alc total $\left(\mathrm{mgCaCO}_{3} \cdot \mathrm{L}^{-1}\right)$ & 64 & 191 & 9 & 181 & 206 \\
\hline DQO bruta $\left(\mathrm{mg} . \mathrm{L}^{-1}\right)$ & 64 & 628 & 40 & 573 & 687 \\
\hline DQO filtrada $\left(\mathrm{mg} \cdot \mathrm{L}^{-1}\right)$ & 64 & 419 & 19 & 394 & 447 \\
\hline $\mathrm{ST}\left(\mathrm{mg} \cdot \mathrm{L}^{-1}\right)$ & 64 & 627 & 62 & 442 & 747 \\
\hline STV (mg.L $\left.L^{-1}\right)$ & 64 & 453 & 76 & 307 & 578 \\
\hline $\mathrm{STF}\left(\mathrm{mg} \cdot \mathrm{L}^{-1}\right)$ & 64 & 174 & 34 & 135 & 205 \\
\hline $\mathrm{SST}\left(\mathrm{mg} \cdot \mathrm{L}^{-1}\right)$ & 64 & 97 & 9 & 85 & 107 \\
\hline $\mathrm{SSV}\left(\mathrm{mg} \cdot \mathrm{L}^{-1}\right)$ & 64 & 85 & 8 & 75 & 94 \\
\hline $\operatorname{SSF}\left(m g . L^{-1}\right)$ & 64 & 12 & 6 & 8 & 19 \\
\hline
\end{tabular}

N: número de amostras; $\bar{X}$ : média aritmética; DP: desvio padrão;

Min: valor mínimo; Máx: valor máximo

\subsection{OPERAÇÃO DO REATOR UASB (146 L)- ETAPA I;}

Conforme descrito na Metodologia, a etapa I compreendeu o início da operação do reator (27/10/2003) até a troca do separador de fases no $291^{\circ}$ dia de operação. Dois perfis de amostragem temporal (181 e $189^{\circ}$ dias de operação) foram realizados nesse período para comparar o desempenho do reator com vazão constante e posteriormente com aplicação de variação cíclica de vazão.

$\mathrm{Na}$ Figura 14 podem ser observadas as variações temporais de $\mathrm{pH}$, alcalinidade a bicarbonato, concentração de ácidos voláteis, DQO bruta e filtrada, concentração de sólidos suspensos totais (SST), concentração de sólidos suspensos voláteis (SSV) e relação SSV/SST. 


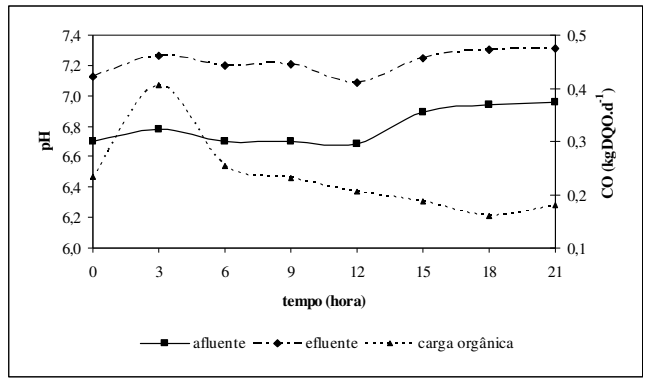

(a)

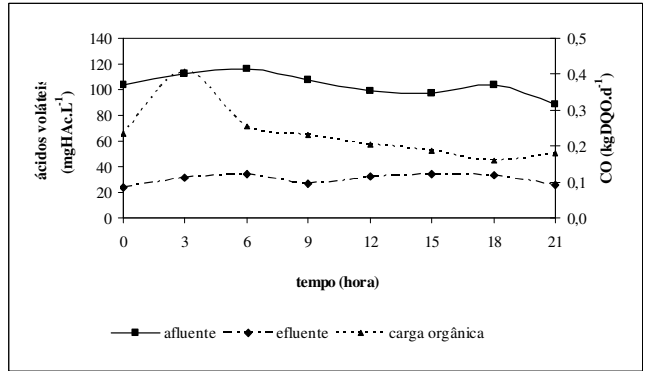

(c)

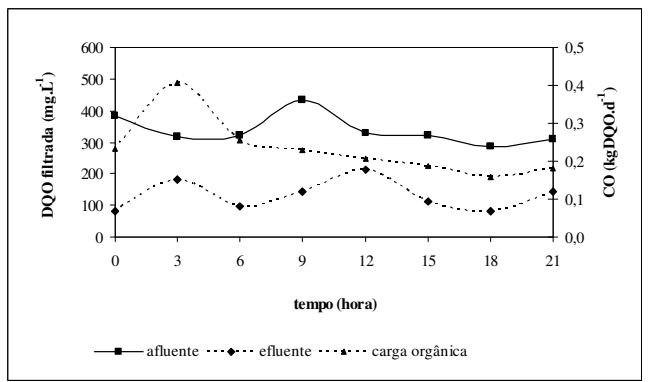

(e)

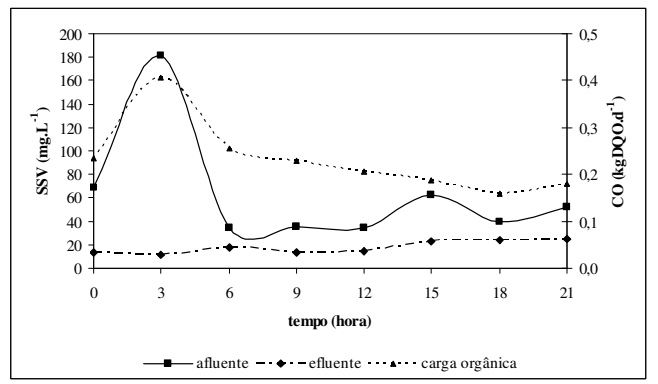

(g)

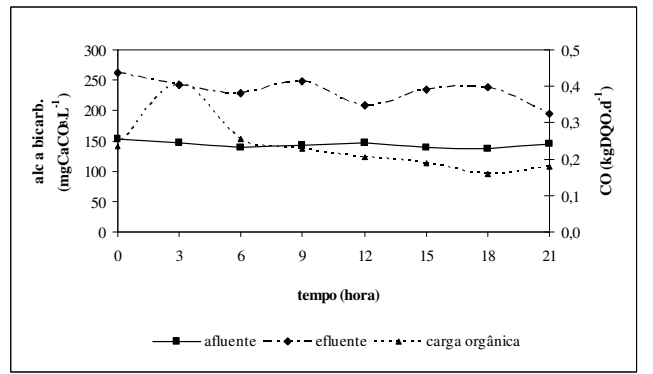

(b)

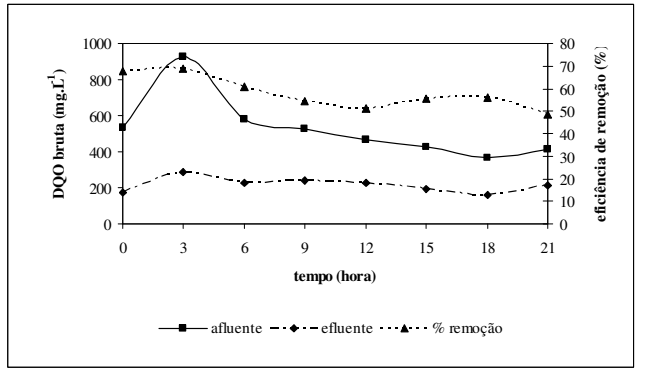

(d)

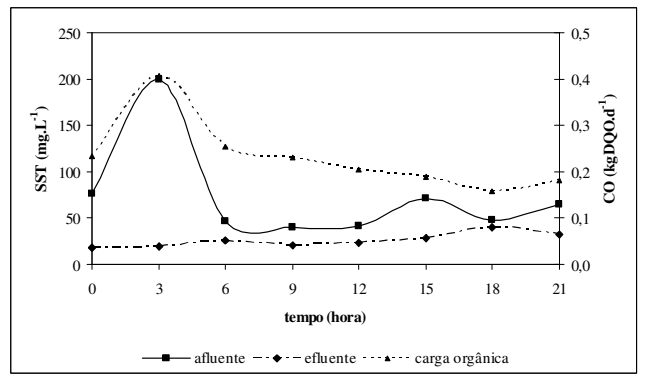

(f)

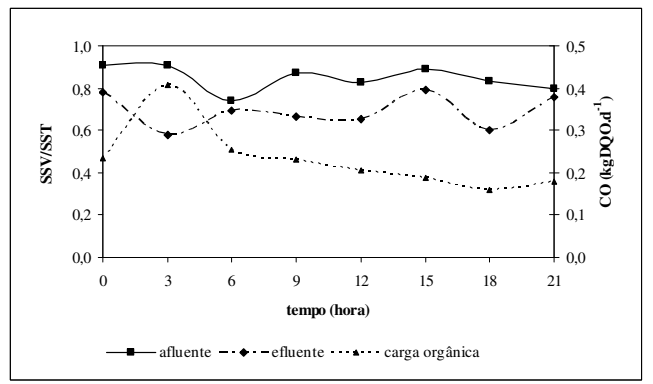

(h)

Figura 14. Resultados do perfil temporal de 24 h do reator: a) pH, b) alcalinidade a bicarbonato, c) concentração de ácidos voláteis, d) DQO bruta, e) DQO filtrada, f) concentração de sólidos suspensos totais, g) concentração de sólidos suspensos voláteis, h) relação SSV/SST (ETAPA I - TDH $=8 \mathrm{~h}$; Vasc $=$ $0,26 \mathrm{~m}^{-h^{-1}}$ ). *O tempo 0 dos gráficos corresponde às $9 \mathrm{~h}$.

Os valores médios obtidos para as temperaturas ambiente e do efluente (líquido) do reator foram de $24,3 \pm 1,3^{\circ} \mathrm{C}$ e $22,8 \pm 0,5^{\circ} \mathrm{C}$, respectivamente. 
Os valores de $\mathrm{pH}$ variaram de 6,7 a 7,0 no afluente e de 7,1 a 7,3 no efluente do reator. Os resultados obtidos para $\mathrm{pH}$ do afluente (Figura 14.a) estão em faixa recomendada para o processo de digestão anaeróbia (SPEECE, 1995).

A alcalinidade total para o afluente e efluente do reator variou de 207 a $228 \mathrm{mgCaCO}_{3} \cdot \mathrm{L}^{-1}$ e de 213 a $280 \mathrm{mgCaCO}_{3} \cdot \mathrm{L}^{-1}$, respectivamente. A alcalinidade a bicarbonato para o afluente e efluente do reator variou na faixa de 137 a $152 \mathrm{mgCaCO}_{3} \cdot \mathrm{L}^{-1}$ e de 195 a $263 \mathrm{mgCaCO}_{3} \cdot \mathrm{L}^{-1}$, respectivamente. É possível observar que os valores de alcalinidades no efluente foram superiores àqueles obtidos no afluente do reator, indicando capacidade do sistema de tamponar o meio.

A concentração de ácidos voláteis manteve-se abaixo de $35 \mathrm{mg} . \mathrm{L}^{-1}$, o que indica possível "equilíbrio" entre as bactérias acetogênicas e as arquéias metanogênicas existentes no sistema.

A concentração de matéria orgânica em termos de DQO bruta no afluente variou significativamente ao longo do tempo de operação do reator, atingindo picos de mínimo e de máximo de $364 \mathrm{mg} . \mathrm{L}^{-1}$ e $928 \mathrm{mg} . \mathrm{L}^{-1}$, respectivamente. Essa variação foi menos acentuada no efluente, atingindo picos de mínimo de $160 \mathrm{mg} . \mathrm{L}^{-1}$ e de máximo de $288 \mathrm{mg} . \mathrm{L}^{-1}$.

O maior pico de concentração de matéria orgânica ocorreu após 3 h do início do perfil devido à alimentação do sistema seguida de agitação que pode ter causado revolvimento dos sólidos suspensos totais e voláteis presentes no fundo dos tanques de armazenamento. É possível observar que a eficiência de remoção do reator foi influenciada diretamente pela concentração de matéria orgânica afluente no período das 3 h às 12 h (Figura 14.d), pois houve variação de 48\% a 68\% para DQO bruta. Por outro lado, o reator foi capaz de absorver essa concentração variável, pois não houve aumento da concentração da matéria orgânica no efluente. Segundo Metcalf e Eddy (1991) isso pode ocorrer devido à capacidade de amortecimento do reator quando operado com maiores tempos de detenção hidráulica.

A carga orgânica imposta ao reator variou na faixa de 0,16 a 0,41 kgDQO.d $\mathrm{d}^{-1}$, obtendo-se média de aproximadamente $0,23 \mathrm{kgDQO} \cdot \mathrm{d}^{-1}$. A taxa de carregamento orgânica resultou na faixa variável de 1,09 a 2,79 $\mathrm{kgDQO} \cdot \mathrm{m}^{-3} \mathrm{~d}^{-1}$, com valor médio de aproximadamente $1,59 \mathrm{kgDQO} \cdot \mathrm{m}^{-3} \mathrm{~d}^{-1}$. O sistema obteve eficiência de remoção de DBO de aproximadamente $79 \%$ para a amostra composta do perfil temporal de $24 \mathrm{~h}$. 
As concentrações de matéria orgânica em termos de DQO filtrada variaram na faixa de $364 \mathrm{mg} . \mathrm{L}^{-1}$ a $433 \mathrm{mg} . \mathrm{L}^{-1}$, para o afluente e na faixa de $82 \mathrm{mg} . \mathrm{L}^{-1}$ a $211 \mathrm{mg} . \mathrm{L}^{-1}$, para o efluente do reator. A eficiência de remoção de DQO filtrada variou de $35 \%$ a $78 \%$, obtendo-se o valor médio de $60 \pm 15 \%$ (Figura 14.e). É importante ressaltar que os valores obtidos para a DQO filtrada no efluente reforçam a importância de um sistema de filtração ou de processo de pós-tratamento para remoção da fração suspensa da DQO.

As concentrações de sólidos suspensos totais variaram de 40 a $200 \mathrm{mg} . \mathrm{L}^{-1}$ para o afluente e de 18 a $40 \mathrm{mg} . \mathrm{L}^{-1}$ para o efluente do reator, com eficiência média de remoção de aproximadamente $53 \pm 22 \%$. Para as concentrações de sólidos suspensos voláteis foram obtidos valores variáveis na faixa de 34 a $181 \mathrm{mg} . \mathrm{L}^{-1}$ para o afluente e de 7 a $25 \mathrm{mg} . \mathrm{L}^{-1}$ para o efluente do reator, com eficiência média de remoção de $82 \pm 12 \%$. É possível notar pela Figura 14.f e Figura 14.g que o pico de máxima concentração de matéria orgânica ocorreu devido à presença de sólidos suspensos totais e de sólidos suspensos voláteis. A parcela volátil dos sólidos suspensos correspondeu aproximadamente a $85 \%$ e $69 \%$ da concentração de sólidos suspensos totais no afluente e efluente do reator, respectivamente.

As concentrações de sólidos totais atingiram picos de mínimo e de máximo iguais a 528 e $876 \mathrm{mg} . \mathrm{L}^{-1}$ e de 290 e $943 \mathrm{mg} . \mathrm{L}^{-1}$ no afluente e no efluente do reator, respectivamente. Para as concentrações de sólidos totais voláteis houve variação de 336 a 754 mg. $\mathrm{L}^{-1}$ para o afluente e de 145 a $743 \mathrm{mg} . \mathrm{L}^{-1}$ para o efluente, respectivamente.

O aumento da concentração de matéria orgânica em termos de DQO ocorreu devido à suplementação do esgoto bruto com esgoto sintético, sem aumento da concentração de sólidos suspensos no afluente. Por outro lado, Mahmoud et al. (2003) ressaltaram que baixas concentrações de sólidos suspensos coincidem com baixas concentrações de matéria orgânica, acarretando em menor oportunidade de colisão dos sólidos do afluente com o manto de lodo. Além disso, pior comportamento é esperado devido às limitações de transferência de massa em concentrações baixas de matéria orgânica.

As concentrações de nitrogênio total (N-NTK) resultaram em $86 \mathrm{mg} . \mathrm{L}^{-1}$ no afluente e $67 \mathrm{mg} . \mathrm{L}^{-1}$ no efluente do reator. As concentrações de nitrogênio amoniacal 
$\left(\mathrm{N}-\mathrm{NH}_{4}{ }^{+}\right)$foram de $66 \mathrm{mg} . \mathrm{L}^{-1}$ no afluente e de $61 \mathrm{mg} . \mathrm{L}^{-1}$ no efluente do reator, ou seja, a eficiência de remoção não foi significativa.

A Tabela 20 apresenta um resumo dos resultados obtidos durante a realização do perfil de amostragem temporal do $181^{\circ}$ dia de operação do reator. Nesse perfil foram coletadas amostras do afluente e do efluente do sistema a cada $3 \mathrm{~h}$ durante o período total de $24 \mathrm{~h}$.

Tabela 20. Resumo dos resultados obtidos no perfil de 24 h do $181^{\circ}$ dia de operação (ETAPA I - TDH $=8 \mathrm{~h}$; Vasc $=0,26 \mathrm{~m} \cdot \mathrm{h}^{-1}$ )

\begin{tabular}{|c|c|c|c|c|c|c|c|c|c|c|}
\hline \multirow[t]{2}{*}{ PARÂMETROS } & \multicolumn{5}{|c|}{ AFLUENTE } & \multicolumn{5}{|c|}{ EFLUENTE } \\
\hline & $\mathrm{N}$ & $\bar{X}$ & DP & Min & Máx & $\mathrm{N}$ & $\bar{X}$ & DP & Min & Máx \\
\hline $\mathrm{pH}$ & 8 & 6,8 & 0,1 & 6,7 & 7,0 & 8 & 7,2 & 0,1 & 7,1 & 7,3 \\
\hline Temperatura do líquido $\left({ }^{\circ} \mathrm{C}\right)$ & - & - & - & - & - & 8 & 22,8 & 0,5 & 22,0 & 23,0 \\
\hline Alc parcial $\left(\mathrm{mgCaCO}_{3} \cdot \mathrm{L}^{-1}\right)$ & 8 & 118 & 6 & 111 & 127 & 8 & 200 & 10 & 180 & 216 \\
\hline Alc total $\left(\mathrm{mgCaCO}_{3} \cdot \mathrm{L}^{-1}\right)$ & 8 & 217 & 8 & 207 & 228 & 8 & 254 & 21 & 213 & 280 \\
\hline Alc bicarbonato $\left(\mathrm{mgCaCO}_{3} \cdot \mathrm{L}^{-1}\right)$ & 8 & 143 & 5 & 137 & 152 & 8 & 232 & 22 & 195 & 263 \\
\hline Ácidos voláteis $\left(\mathrm{mgHAC} . \mathrm{L}^{-1}\right)$ & 8 & 103 & 9 & 88 & 116 & 8 & 30 & 4 & 24 & 35 \\
\hline DQO bruta $\left(\mathrm{mg} \cdot \mathrm{L}^{-1}\right)$ & 8 & 530 & 176 & 364 & 928 & 8 & 215 & 41 & 160 & 288 \\
\hline \% remoção DQO bruta & - & - & - & - & - & - & 58 & - & - & - \\
\hline DQO filtrada (mg. $\left.\mathrm{L}^{-1}\right)$ & 8 & 337 & 47 & 364 & 433 & 8 & 132 & 48 & 82 & 211 \\
\hline $\mathrm{DBO}\left(\mathrm{mg} \cdot \mathrm{L}^{-1}\right)$ & & 215 & (amostr: & posta) & & & 46 & (amostr & posta) & \\
\hline \% remoção DBO & - & - & - & - & - & - & 79 & - & - & - \\
\hline $\mathrm{ST}\left(\mathrm{mg} \cdot \mathrm{L}^{-1}\right)$ & 8 & 681 & 127 & 528 & 876 & 8 & 500 & 194 & 290 & 943 \\
\hline STV $\left(m g . L^{-1}\right)$ & 8 & 499 & 128 & 336 & 754 & 8 & 297 & 187 & 145 & 743 \\
\hline STF (mg.L $\left.L^{-1}\right)$ & 8 & 182 & 44 & 122 & 258 & 8 & 203 & 33 & 145 & 258 \\
\hline SST (mg. $\left.\mathrm{L}^{-1}\right)$ & 8 & 74 & 53 & 40 & 200 & 8 & 29 & 8 & 18 & 40 \\
\hline SSV (mg.L -1 $\left.^{-1}\right)$ & 8 & 64 & 49 & 34 & 181 & 8 & 16 & 7 & 7 & 25 \\
\hline $\mathrm{SSF}\left(\mathrm{mg} \cdot \mathrm{L}^{-1}\right)$ & 8 & 10 & 5 & 5 & 19 & 8 & 12 & 8 & 4 & 28 \\
\hline
\end{tabular}

N: número de amostras; $\quad \bar{X}$ : média aritmética; DP: desvio padrão; Min: valor mínimo; Máx: valor máximo

A Figura 15 apresenta as variações temporais de $\mathrm{pH}$, alcalinidade a bicarbonato, concentração de ácidos voláteis, DQO de amostras brutas, DQO de amostras filtradas, concentração de sólidos suspensos totais (SST), concentração de sólidos suspensos voláteis (SSV) e relação SSV/SST. 


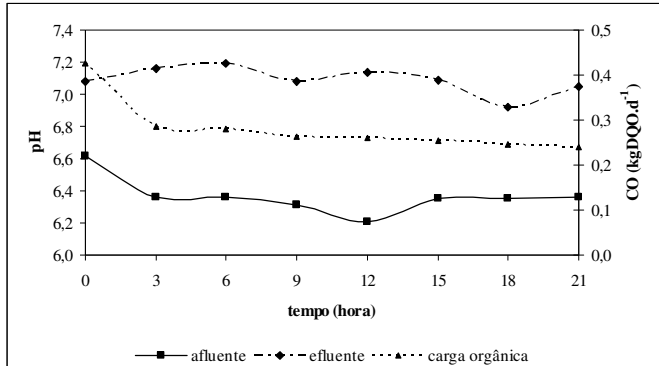

a)

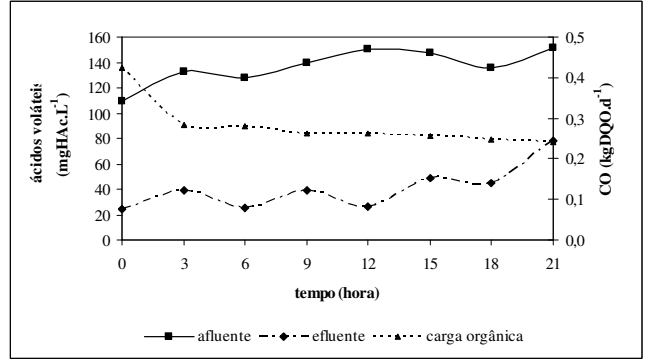

c)

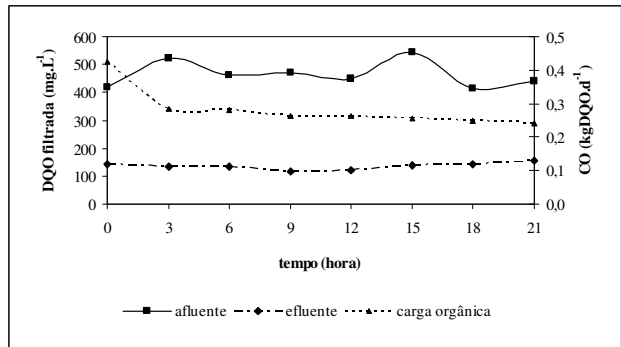

e)

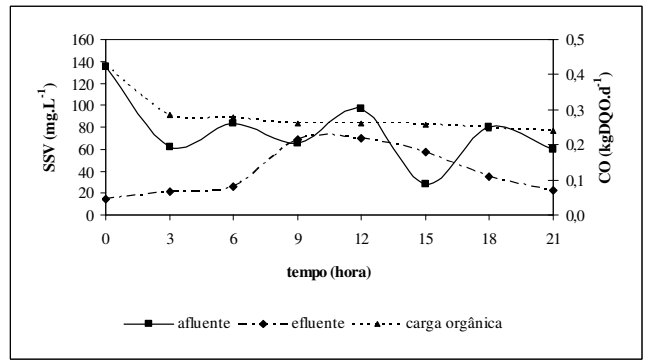

g)

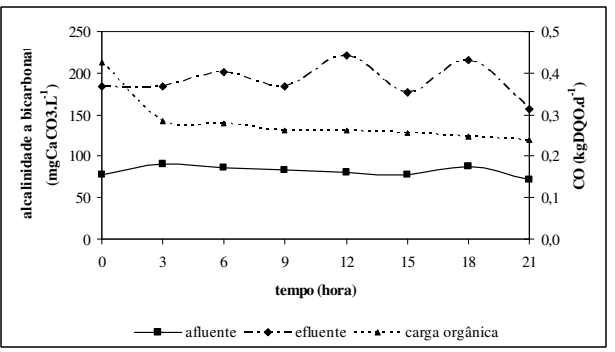

b)

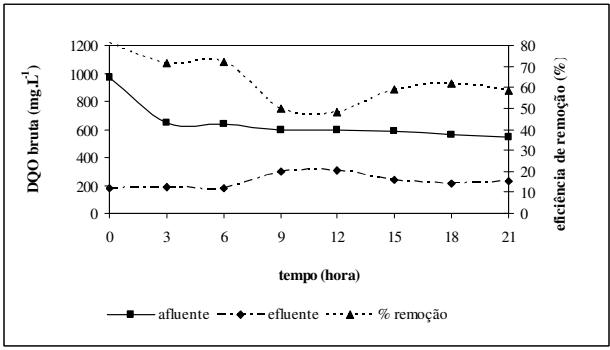

d)

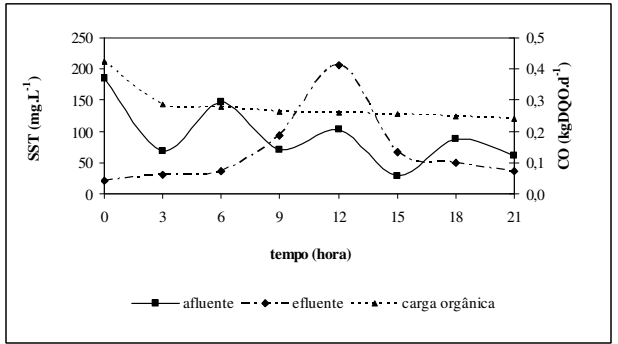

f)

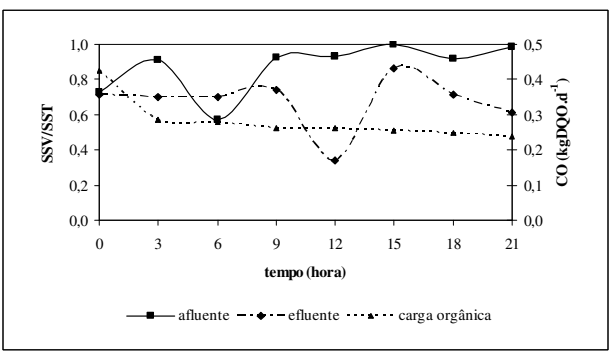

h)

Figura 15. Resultados do perfil de $24 \mathrm{~h}$ de amostragem temporal do reator a) pH, b) alcalinidade a bicarbonato, c) concentração de ácidos voláteis, d) DQO bruta, e) DQO filtrada, f) concentração de sólidos suspensos totais, g) concentração de sólidos suspensos voláteis, h) relação SSV/SST (ETAPA I TDH $=8 \mathrm{~h}$; Vasc $\left.=0,26 \mathrm{~m} \cdot \mathrm{h}^{-1}\right)$. *O tempo 0 dos gráficos corresponde às $9 \mathrm{~h}$.

Os valores médios obtidos para temperatura ambiente e para a temperatura do efluente (líquido) do reator foram de $22,8 \pm 1,7^{\circ} \mathrm{C}$ e $20,9 \pm 0,7^{\circ} \mathrm{C}$, respectivamente. 
Os valores de $\mathrm{pH}$ variaram de 6,2 a 6,6 no afluente e de 6,9 a 7,2 no efluente do reator (Figura 15.a).

A alcalinidade total para o afluente e efluente do reator variou de 155 a $187 \mathrm{mgCaCO}_{3} \cdot \mathrm{L}^{-1}$ e de 201 a $248 \mathrm{mgCaCO}_{3} \mathrm{~L}^{-1}$, respectivamente. A alcalinidade a bicarbonato para o afluente e efluente do reator variou na faixa de 72 a $90 \mathrm{mgCaCO}_{3} \cdot \mathrm{L}^{-1}$ e de 156 a $221 \mathrm{mgCaCO}_{3} \cdot \mathrm{L}^{-1}$, respectivamente. É possível observar na Figura 15.b que os valores de alcalinidades para o efluente do sistema resultaram superiores àqueles obtidos para as alcalinidades do afluente, o que indicou capacidade de tamponamento do sistema.

As concentrações de ácidos voláteis variaram de 109 a $151 \mathrm{mg} \cdot \mathrm{L}^{-1}$ e de 25 a $78 \mathrm{mg} . \mathrm{L}^{-1}$ no afluente e efluente do reator, respectivamente. Na Figura 15.c é possível observar o aumento da concentração de ácidos voláteis no efluente para $77 \mathrm{mg} . \mathrm{L}^{-1}$ às $21 \mathrm{~h}$, o que acarretou diminuição da concentração de alcalinidade nesse período.

As concentrações de matéria orgânica em termos de DQO bruta variaram de 547 a $969 \mathrm{mg} . \mathrm{L}^{-1}$ (em torno de 56\%) no afluente e de 118 a $299 \mathrm{mg} . \mathrm{L}^{-1}$ no efluente (em torno de $39 \%$ ). O pico máximo de DQO afluente ocorreu às $0 \mathrm{~h}$, provavelmente devido às concentrações elevadas de sólidos suspensos totais $\left(185 \mathrm{mg} . \mathrm{L}^{-1}\right)$ e de sólidos suspensos voláteis (135 mg.L $\left.\mathrm{L}^{-1}\right)$ no afluente nesse período (Figura 15.f e Figura 15.g). Esse pico influenciou a concentração de matéria orgânica no efluente devido à diminuição da eficiência de remoção do sistema. A eficiência de remoção de matéria orgânica do sistema variou de $50 \%$ a $87 \%$ em termos de DQO bruta, obtendo-se valor médio de aproximadamente $64 \pm 11 \%$.

A carga orgânica imposta ao reator variou na faixa de 0,24 a 0,42 kgDQO.d $\mathrm{d}^{-1}$, obtendo-se média de aproximadamente $0,28 \mathrm{kgDQO}^{-1}$. A taxa de carregamento orgânica variou na faixa de 1,64 a 2,91 kgDQO.m $\mathrm{m}^{-3} \mathrm{~d}^{-1}$, com valor médio de aproximadamente $1,93 \mathrm{kgDQO} \cdot \mathrm{m}^{-3} \mathrm{~d}^{-1}$. A eficiência média de remoção de DBO resultou em $79 \pm \%$ para a amostra composta do perfil temporal de $24 \mathrm{~h}$.

As concentrações de matéria orgânica em termos de DQO filtrada mantiveram-se nas faixas de 413 a $545 \mathrm{mg} . \mathrm{L}^{-1}$ para o afluente e de 118 a $157 \mathrm{mg} . \mathrm{L}^{-1}$ para o efluente do reator. A eficiência de remoção de DQO filtrada variou de $64 \%$ a $75 \%$, com valor médio de aproximadamente 70 $\pm 5 \%$ (Figura 15.e). 
As concentrações de sólidos suspensos totais resultaram em valores de mínimo e de máximo de 28 a $185 \mathrm{mg} . \mathrm{L}^{-1}$ e de 21 a $206 \mathrm{mg} . \mathrm{L}^{-1}$ no afluente e efluente do reator, respectivamente, com eficiência média de remoção de aproximadamente $61 \pm 20 \%$. Para as concentrações de sólidos suspensos voláteis os valores obtidos foram de 28 a $135 \mathrm{mg} . \mathrm{L}^{-1}$ para o afluente e de 15 a $70 \mathrm{mg} . \mathrm{L}^{-1}$ para o efluente, com eficiência média de remoção de aproximadamente 62 $20 \%$. Na Figura 15.f e Figura 15.g observou-se arraste de SST e SSV do sistema no período de 18 h às $24 \mathrm{~h}$. A parcela volátil dos sólidos suspensos correspondeu a aproximadamente $87 \%$ e $67 \%$ da concentração de sólidos suspensos totais no afluente e efluente do reator, respectivamente.

As concentrações de sólidos totais variaram de $403 \mathrm{mg} . \mathrm{L}^{-1}$ a $824 \mathrm{mg} . \mathrm{L}^{-1}$ para o afluente e de $353 \mathrm{mg} . \mathrm{L}^{-1}$ a $552 \mathrm{mg} . \mathrm{L}^{-1}$ para o efluente do reator. Os resultados obtidos para as concentrações de sólidos totais voláteis foram de 223 a $635 \mathrm{mg} . \mathrm{L}^{-1} \mathrm{e}$ de 152 a $332 \mathrm{mg} . \mathrm{L}^{-1}$ para o afluente e efluente do reator, respectivamente.

As concentrações de nitrogênio total (N-NTK) resultaram em $62 \mathrm{mg} . \mathrm{L}^{-1} \mathrm{e}$ $49 \mathrm{mg} . \mathrm{L}^{-1}$ para o afluente e efluente do reator, respectivamente. As concentrações de nitrogênio amoniacal $\left(\mathrm{N}-\mathrm{NH}_{4}{ }^{+}\right)$resultaram em $39 \mathrm{mg} . \mathrm{L}^{-1}$ para o afluente e $30 \mathrm{mg} . \mathrm{L}^{-1}$ para o efluente do reator. As análises de nitrogênio total (N-NTK) e de nitrogênio amoniacal $\left(\mathrm{N}-\mathrm{NH}_{4}{ }^{+}\right)$também foram realizadas com amostras compostas do perfil temporal.

A eficiência de remoção de DQO foi prejudicada nessa etapa de operação devido à elevada concentração de sólidos no efluente do reator. O arraste ocorreu provavelmente pela formação de "bolsões de biogás" que carreavam os sólidos para a saída do reator. Esse fenômeno foi presenciado algumas vezes durante a realização dos perfis temporais de amostragem do reator. Portanto, verificou-se a necessidade de substituir o separador de fases utilizado por outro separador com maior abertura para a passagem do efluente, diminuindo a velocidade ascensional do fluxo.

A Tabela 21 apresenta um resumo dos resultados obtidos durante a realização do perfil temporal realizado no $189^{\circ}$ dia de operação do reator. Nesse perfil também foram coletadas amostras do afluente e do efluente do sistema a cada $3 \mathrm{~h}$ durante o período total de $24 \mathrm{~h}$. 
Tabela 21. Resumo dos resultados obtidos no perfil de 24 h do $189^{\circ}$ dia de operação (ETAPA I - TDH $=8 \mathrm{~h}$; Vasc $=0,26 \mathrm{~m}^{-\mathrm{h}^{-1}}$ )

\begin{tabular}{|c|c|c|c|c|c|c|c|c|c|c|}
\hline \multirow[t]{2}{*}{ PARÂMETROS } & \multicolumn{5}{|c|}{ AFLUENTE } & \multicolumn{5}{|c|}{ EFLUENTE } \\
\hline & $\mathrm{N}$ & $\bar{X}$ & DP & Min & Máx & $\mathrm{N}$ & $\bar{X}$ & DP & Min & Máx \\
\hline $\mathrm{pH}$ & 8 & 6,4 & 0,1 & 6,2 & 6,6 & 8 & 7,1 & 0,1 & 6,9 & 7,2 \\
\hline Temperatura do líquido $\left({ }^{\circ} \mathrm{C}\right)$ & - & - & - & - & - & 8 & 20,9 & 0,7 & 20,0 & 22,0 \\
\hline Alc parcial $\left(\mathrm{mgCaCO}_{3} \cdot \mathrm{L}^{-1}\right)$ & 8 & 75 & 4 & 70 & 83 & 8 & 169 & 6 & 160 & 179 \\
\hline Alc total $\left(\mathrm{mgCaCO}_{3} \cdot \mathrm{L}^{-1}\right)$ & 8 & 179 & 10 & 155 & 187 & 8 & 219 & 16 & 201 & 248 \\
\hline Alc bicarbonato $\left(\mathrm{mgCaCO}_{3} \cdot \mathrm{L}^{-1}\right)$ & 8 & 82 & 6 & 72 & 90 & 8 & 190 & 21 & 156 & 221 \\
\hline Ácidos voláteis (mgHAC.L $\left.\mathrm{L}^{-1}\right)$ & 8 & 137 & 14 & 109 & 151 & 8 & 41 & 18 & 25 & 78 \\
\hline DQO bruta $\left(\mathrm{mg} \cdot \mathrm{L}^{-1}\right)$ & 8 & 643 & 136 & 547 & 969 & 8 & 221 & 63 & 118 & 310 \\
\hline \% remoção DQO bruta & - & - & - & - & - & - & 64 & - & - & - \\
\hline DQO filtrada (mg. $\left.\mathrm{L}^{-1}\right)$ & 8 & 465 & 47 & 413 & 545 & 8 & 136 & 13 & 118 & 157 \\
\hline $\mathrm{DBO}\left(\mathrm{mg} \cdot \mathrm{L}^{-1}\right)$ & & 477 & (amostra & posta) & & & 73 & (amostr & posta) & \\
\hline \% remoção DBO & - & - & - & - & - & - & 85 & - & - & - \\
\hline ST $\left(\mathrm{mg} \cdot \mathrm{L}^{-1}\right)$ & 8 & 591 & 117 & 403 & 824 & 8 & 432 & 70 & 353 & 552 \\
\hline STV $\left(\mathrm{mg} \cdot \mathrm{L}^{-1}\right)$ & 8 & 389 & 119 & 223 & 635 & 8 & 247 & 65 & 152 & 332 \\
\hline STF (mg.L $\left.L^{-1}\right)$ & 8 & 202 & 19 & 180 & 239 & 8 & 185 & 30 & 129 & 220 \\
\hline SST (mg.L $\left.\mathrm{L}^{-1}\right)$ & 8 & 93 & 50 & 28 & 185 & 8 & 68 & 61 & 21 & 206 \\
\hline $\operatorname{SSV}\left(\mathrm{mg} \cdot \mathrm{L}^{-1}\right)$ & 8 & 76 & 31 & 28 & 135 & 8 & 40 & 23 & 15 & 70 \\
\hline $\operatorname{SSF}\left(\mathrm{mg} \cdot \mathrm{L}^{-1}\right)$ & 8 & 17 & 25 & 0 & 63 & 8 & 28 & 44 & 6 & 136 \\
\hline
\end{tabular}

N: número de amostras; $\bar{X}$ : média aritmética; DP: desvio padrão; Min: valor mínimo; Máx: valor máximo

A concentração variável do substrato utilizado na alimentação foi outro fator que influenciou na estabilidade do sistema. Mesmo com a suplementação do esgoto bruto com esgoto sintético na concentração $300 \mathrm{mg} . \mathrm{L}^{-1}$, não havia controle da concentração de matéria orgânica do esgoto bruto (em termos de DQO) afluente à estação elevatória do laboratório.

\subsection{OPERAÇÃO DO REATOR UASB (160 L)- ETAPA II;}

A etapa II compreendeu o início da operação do reator com novo separador de fases entre os dias $292^{\circ}$ e $319^{\circ}$ dia de operação do reator. As condições operacionais do sistema sofreram alterações para vazão média afluente de 16,0 L.h ${ }^{-1}$ e tempo de detenção hidráulica de 10 h com a substituição do separador de fases. $\mathrm{O}$ principal objetivo da troca do separador de fases e da redução da vazão média afluente de 18,2 L.h ${ }^{-1}$ para 16,0 L.h ${ }^{-1}$ foi evitar o arraste de biomassa no efluente do sistema, diminuindo a velocidade ascensional de fluxo.

Dois perfis temporais de amostragem foram realizados nos dias $304^{\circ}$ dia e $309^{\circ}$, após o reator ter atingido o estado de equilíbrio dinâmico aparente no $303^{\circ}$ dia de operação. 
O desempenho do reator foi avaliado por meio da determinação dos mesmos parâmetros de controle da etapa I. Determinações de nitrogênio total (N-NTK) e de nitrogênio amoniacal $\left(\mathrm{N}-\mathrm{NH}_{4}{ }^{+}\right)$de amostras compostas do afluente e efluente foram realizadas nesses perfis.

A Figura 16 apresenta as variações temporais de $\mathrm{pH}$, alcalinidade a bicarbonato, concentração de ácidos voláteis, DQO de amostras brutas, DQO de amostras filtradas, concentração de sólidos suspensos totais (SST), concentração de sólidos suspensos voláteis (SSV) e relação SSV/SST.

Os valores médios obtidos para temperatura ambiente e para a temperatura do efluente (líquido) do reator foram de $23,0 \pm 1,9^{\circ} \mathrm{C}$ e $23,9 \pm 1,0^{\circ} \mathrm{C}$, respectivamente.

Os valores de $\mathrm{pH}$ variaram de 6,2 a 6,4 nas amostras do afluente e de 6,8 a 7,1 nas amostras do efluente do reator (Figura 16.a).

Os valores de alcalinidade total variaram de 244 a $295 \mathrm{mg} \mathrm{CaCO}_{3} \cdot \mathrm{L}^{-1}$ no efluente do reator e foram superiores àqueles obtidos para o afluente, que variaram de 184 a $206 \mathrm{mg} \mathrm{CaCO}_{3} \mathrm{~L}^{-1}$. O mesmo comportamento foi observado para a alcalinidade a bicarbonato, que variou de 52 a $117 \mathrm{mg} \mathrm{CaCO}_{3} \cdot \mathrm{L}^{-1}$ para o afluente e de 211 a $261 \mathrm{mg} \mathrm{CaCO}_{3} \cdot \mathrm{L}^{-1}$ para o efluente do reator. Assim, o sistema manteve a capacidade de tamponamento do meio, analogamente ao comportamento observado na etapa $\mathrm{I}$.

A concentração de ácidos voláteis foi inferior a $54 \mathrm{mgHAc} . \mathrm{L}^{-1}$ no efluente do sistema, com concentração variável de 26 a 54 mgHAc. $\mathrm{L}^{-1}$. Na amostra das $18 \mathrm{~h}$ verificou-se geração de ácidos voláteis no afluente, provavelmente devido à prévia degradação do substrato nos tanques de alimentação do sistema.

$\mathrm{O}$ pico de maior concentração de matéria orgânica afluente ocorreu às $15 \mathrm{~h}$ devido à alimentação do sistema. As concentrações de matéria orgânica em termos de DQO bruta variaram ao longo do tempo de operação do reator na faixa de 588 a 909 mg.L $\mathrm{L}^{-1}$ (em torno de 65\%) no afluente e de 207 a 360 mg.L $\mathrm{L}^{-1}$ (em torno de 57\%) no efluente. A eficiência média de remoção de matéria orgânica foi de $61 \pm 11 \%$, com variação de $39 \%$ a $74 \%$ para DQO bruta. 


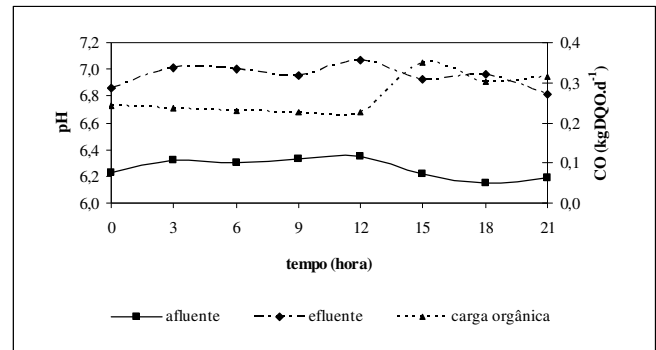

a)

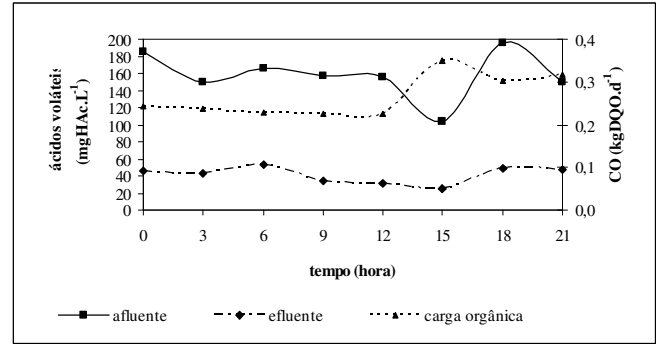

c)

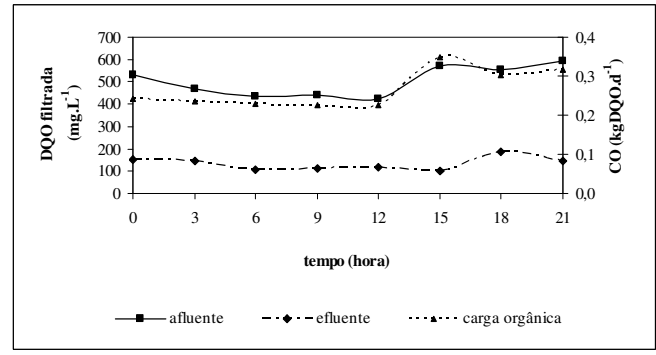

e)

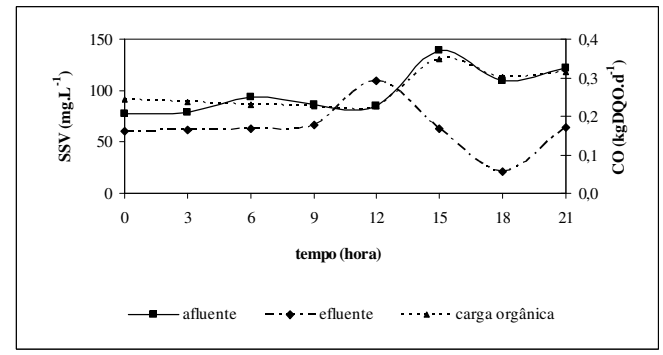

g)

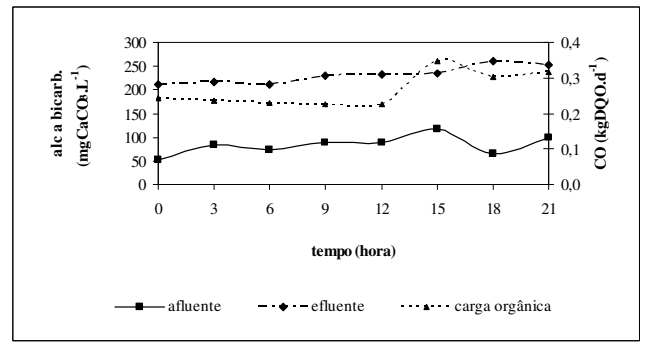

b)

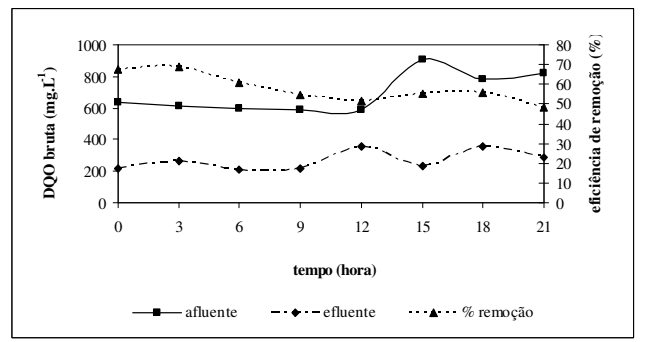

d)

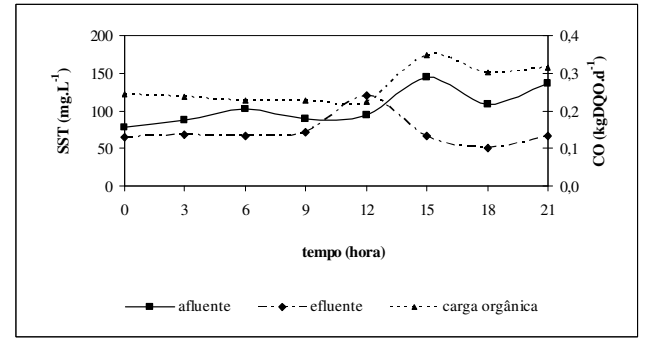

f)

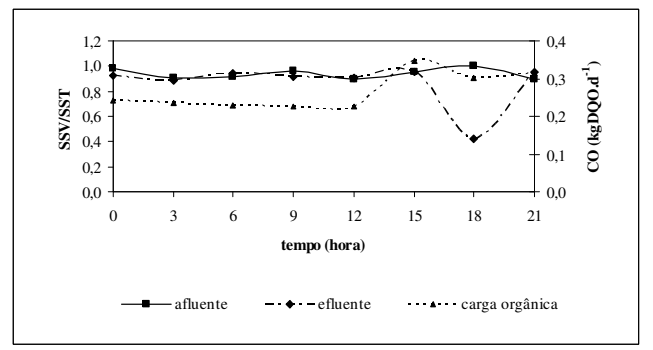

h)

Figura 16. Resultados do perfil de $24 \mathrm{~h}$ de amostragem temporal do reator no dia $304^{\circ}$ dia a) $\mathrm{pH}$, b) alcalinidade a bicarbonato, c) concentração de ácidos voláteis, d) DQO bruta, e) DQO filtrada, f) concentração de sólidos suspensos totais, g) concentração de sólidos suspensos voláteis, h) relação SSV/SST. (ETAPA II- TDH $=10 \mathrm{~h} ;$ Vasc $\left.=0,23 \mathrm{~m} \cdot \mathrm{h}^{-1}\right)$. *O tempo 0 dos gráficos corresponde às $9 \mathrm{~h}$.

A carga orgânica imposta ao reator variou de 0,23 a 0,35 kgDQO.d $\mathrm{d}^{-1}$, obtendo-se média de aproximadamente $0,27 \mathrm{kgDQO} \cdot \mathrm{d}^{-1}$. A taxa de carregamento 
orgânica resultou na faixa variável de 1,41 a 2,18 $\mathrm{kgDQO} \cdot \mathrm{m}^{-3} \mathrm{~d}^{-1}$, com valor médio de aproximadamente $1,66 \mathrm{kgDQO} \cdot \mathrm{m}^{-3} \mathrm{~d}^{-1}$.

As concentrações de matéria orgânica em termos de DQO filtrada variaram de $426 \mathrm{mg} . \mathrm{L}^{-1}$ a $595 \mathrm{mg} . \mathrm{L}^{-1}$ para o afluente e de $99 \mathrm{mg} . \mathrm{L}^{-1}$ a $189 \mathrm{mg} . \mathrm{L}^{-1}$ para o efluente do reator. A eficiência de remoção de DQO filtrada variou de $66 \%$ a $83 \%$,

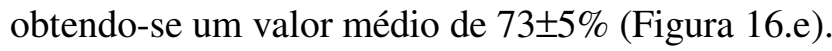

As concentrações de sólidos suspensos totais resultaram em faixa variável de 78 a $145 \mathrm{mg} . \mathrm{L}^{-1}$ para o afluente e de 50 a $120 \mathrm{mg} . \mathrm{L}^{-1}$ para o efluente do reator, com eficiência média de remoção de aproximadamente $36 \pm 17 \%$. Para as concentrações de sólidos suspensos voláteis foram obtidos valores variáveis na faixa de 77 a $139 \mathrm{mg} . \mathrm{L}^{-1}$ para o afluente e de 21 a $109 \mathrm{mg} . \mathrm{L}^{-1}$ para o efluente do reator, com eficiência média de remoção de $40 \pm 15 \%$. É possível notar pela Figura 16.f e Figura 16.g que houve arraste de sólidos suspensos totais e de sólidos suspensos voláteis no período das $10 \mathrm{~h}$ às $13 \mathrm{~h}$.

$\mathrm{O}$ arraste de sólidos no efluente do reator no período das $10 \mathrm{~h}$ às $13 \mathrm{~h}$ pode ter ocorrido devido à formação de "bolsões" de biogás no manto de lodo do reator. O menor volume de substrato presente nos tanques de armazenamento antes do período de alimentação do sistema às $15 \mathrm{~h}$ e conseqüentemente a maior concentração de sólidos (SST, SSV) depositada no fundo desses tanques foi outro fator que pode ter contribuído no aumento do arraste de sólidos no efluente do reator. Para minimizar o carreamento dos sólidos presentes no fundo dos tanques, que além de causar o entupimento da bomba e das tubulações de alimentação, poderiam contribuir para a pré-degradação do substrato, optou-se pela realização de limpeza periódica semanal.

Como parte do procedimento de alimentação, após a suplementação com esgoto sintético, era realizada agitação manual dos tanques para promover maior mistura entre o esgoto bruto e o esgoto sintético. Essa agitação acarretava no revolvimento da biomassa presente no fundo dos tanques de alimentação e conseqüentemente no aumento da concentração de sólidos no afluente do sistema.

A parcela volátil dos sólidos suspensos correspondeu a aproximadamente 94\% e $86 \%$ da concentração de sólidos suspensos totais no afluente e efluente do reator, respectivamente. 
As concentrações de nitrogênio total (N-NTK) e de nitrogênio amoniacal (N$\left.\mathrm{NH}_{4}{ }^{+}\right)$no afluente e efluente do perfil temporal do reator resultaram em $63 \mathrm{mg} \cdot \mathrm{L}^{-1} \mathrm{e}$ $54 \mathrm{mg} . \mathrm{L}^{-1}$ e de $38 \mathrm{mg} . \mathrm{L}^{-1}$ e $31 \mathrm{mg} . \mathrm{L}^{-1}$, respectivamente.

A Tabela 22 apresenta o resumo dos resultados obtidos durante a realização do perfil de amostragem temporal no dia $304^{\circ}$ de operação do reator. Nesse perfil foram coletadas amostras do afluente e do efluente do sistema a cada $3 \mathrm{~h}$ durante o período total de $24 \mathrm{~h}$.

Tabela 22. Resumo dos resultados obtidos no perfil de 24 h do $304^{\circ}$ dia de operação (ETAPA II - TDH = 10h; Vasc $=0,23 \mathrm{~m} \cdot \mathrm{h}^{-1}$ )

\begin{tabular}{|c|c|c|c|c|c|c|c|c|c|c|}
\hline \multirow[t]{2}{*}{ PARÂMETROS } & \multicolumn{5}{|c|}{ AFLUENTE } & \multicolumn{5}{|c|}{ EFLUENTE } \\
\hline & $\mathrm{N}$ & $\bar{X}$ & $\mathrm{DP}$ & Min & Máx & $\mathrm{N}$ & $\bar{X}$ & DP & Min & Máx \\
\hline $\mathrm{pH}$ & 8 & 6,3 & 0,1 & 6,2 & 6,4 & 8 & 6,9 & 0,1 & 6,8 & 7,1 \\
\hline Temperatura do líquido $\left({ }^{\circ} \mathrm{C}\right)$ & - & - & - & - & - & 8 & 23,9 & 1,0 & 22,0 & 25,0 \\
\hline Alc parcial $\left(\operatorname{mgCaCO} 3 . \mathrm{L}^{-1}\right)$ & 8 & 65 & 5 & 59 & 73 & 8 & 179 & 10 & 168 & 195 \\
\hline Alc total $\left(\mathrm{mgCaCO} 3 \cdot \mathrm{L}^{-1}\right)$ & 8 & 196 & 8 & 184 & 206 & 8 & 261 & 19 & 244 & 295 \\
\hline Alc bicarbonato $\left(\mathrm{mgCaCO} 3 \cdot \mathrm{L}^{-1}\right)$ & 8 & 84 & 20 & 52 & 117 & 8 & 231 & 18 & 211 & 261 \\
\hline Ácidos voláteis $\left(\operatorname{mgHAC} . \mathrm{L}^{-1}\right)$ & 8 & 145 & 28 & 103 & 196 & 8 & 41 & 10 & 26 & 54 \\
\hline DQO bruta $\left(\mathrm{mg} \cdot \mathrm{L}^{-1}\right)$ & 8 & 693 & 127 & 588 & 909 & 8 & 267 & 62 & 207 & 360 \\
\hline \% remoção DQO bruta & - & - & - & - & - & - & 61 & - & - & - \\
\hline DQO filtrada (mg. $\left.\mathrm{L}^{-1}\right)$ & 8 & 502 & 69 & 426 & 595 & 8 & 134 & 30 & 99 & 189 \\
\hline $\operatorname{SST}\left(\mathrm{mg} \cdot \mathrm{L}^{-1}\right)$ & 8 & 105 & 24 & 78 & 145 & 8 & 72 & 20 & 50 & 120 \\
\hline $\operatorname{SSV}\left(\mathrm{mg} \cdot \mathrm{L}^{-1}\right)$ & 8 & 99 & 22 & 77 & 139 & 8 & 63 & 24 & 21 & 109 \\
\hline $\mathrm{SSF}\left(\mathrm{mg} \cdot \mathrm{L}^{-1}\right)$ & 8 & 6 & 5 & 0 & 14 & 8 & 9 & 9 & 3 & 29 \\
\hline
\end{tabular}

A Figura 17 apresenta as variações temporais de $\mathrm{pH}$, alcalinidade a bicarbonato, concentração de ácidos voláteis, DQO de amostras brutas, DQO de amostras filtradas, concentração de sólidos suspensos totais (SST), concentração de sólidos suspensos voláteis (SSV) e relação SSV/SST.

Os valores médios obtidos para temperatura ambiente e para a temperatura do efluente (líquido) do reator foram de $25,1 \pm 3,4^{\circ} \mathrm{C}$ e $24,1 \pm 1,0^{\circ} \mathrm{C}$, respectivamente.

Os valores de $\mathrm{pH}$ variaram de 6,2 a 6,3 no afluente e de 6,8 a 7,0 no efluente do reator (Figura 17.a).

Os valores de alcalinidade total variaram de 228 a $281 \mathrm{mgCaCO}_{3} \cdot \mathrm{L}^{-1}$ no efluente do reator e foram superiores àqueles obtidos para o afluente, que variaram de 194 a $226 \mathrm{mgCaCO}_{3} \cdot \mathrm{L}^{-1}$. O mesmo comportamento foi observado para a alcalinidade a bicarbonato, que variou de 206 a $259 \mathrm{mgCaCO}_{3} \cdot \mathrm{L}^{-1}$ para o efluente e de 105 a $151 \mathrm{mgCaCO}_{3} \cdot \mathrm{L}^{-1}$ para o afluente do reator. Assim, conforme observado nas etapas anteriores, o sistema apresentou capacidade de tamponamento do meio. 


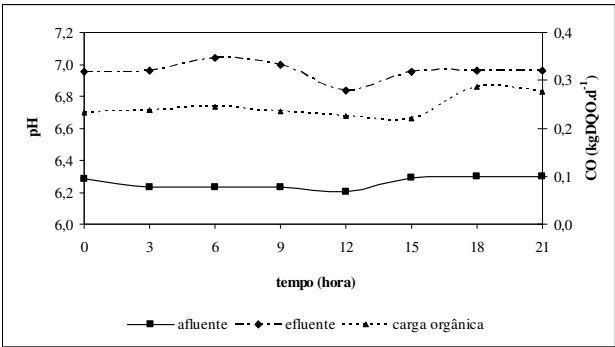

a)

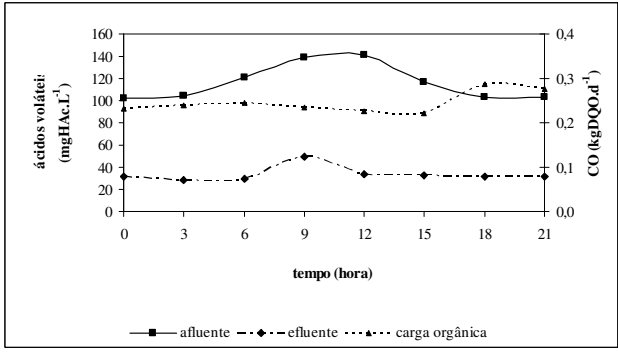

c)

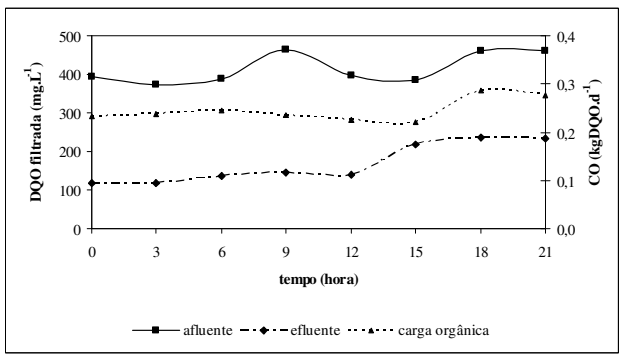

e)

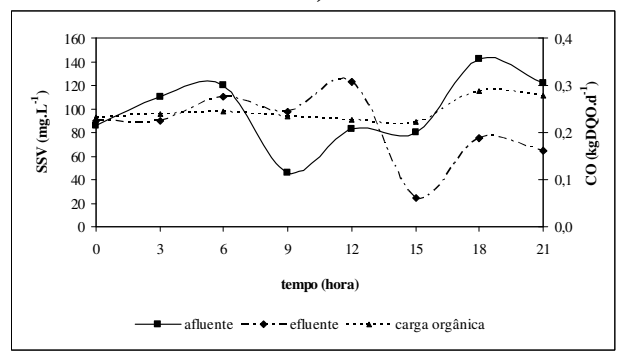

g)

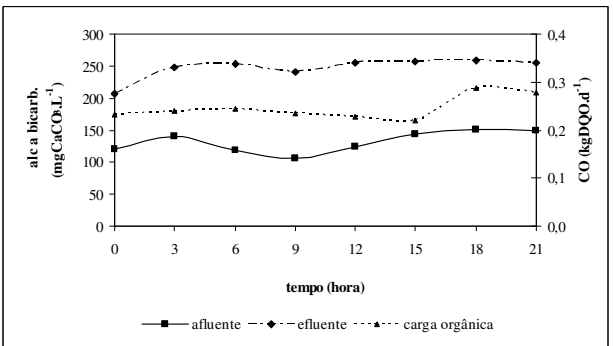

b)

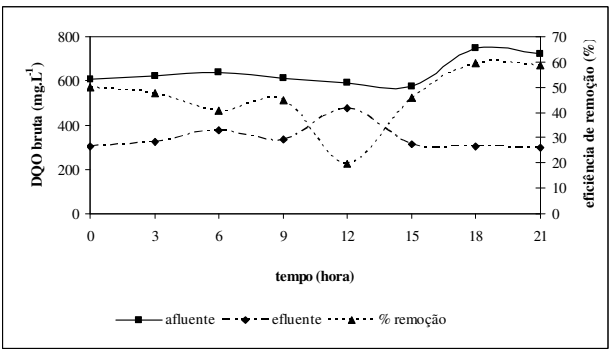

d)

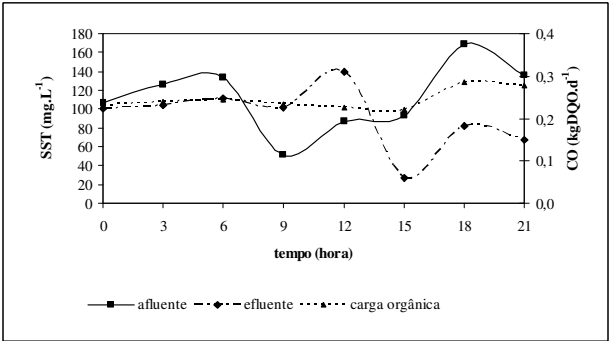

f)

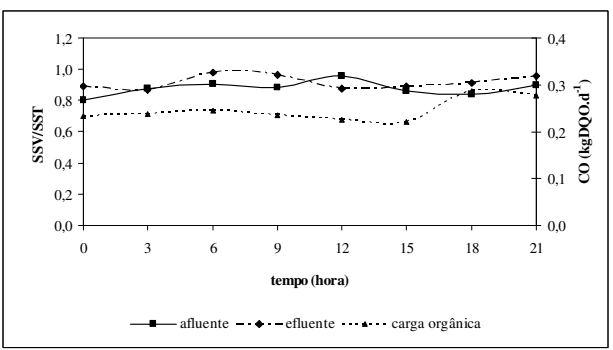

h)

Figura 17. Resultados do perfil de $24 \mathrm{~h}$ de amostragem temporal do reator no dia $309^{\circ}$ a) pH, b) alcalinidade a bicarbonato, c) concentração de ácidos voláteis, d) DQO bruta, e) DQO filtrada, f) concentração de sólidos suspensos totais, g) concentração de sólidos suspensos voláteis, h) relação SSV/SST. (ETAPA II$\left.\mathrm{TDH}=8 \mathrm{~h} ; \operatorname{Vasc}=0,23 \mathrm{~m} \cdot \mathrm{h}^{-1}\right)$. $* \mathrm{O}$ tempo 0 dos gráficos corresponde às $9 \mathrm{~h}$.

A concentração média de ácidos voláteis resultou em 33 mgHAc. $\mathrm{L}^{-1}$ no efluente do sistema, com concentração variável de 28 a 49 mgHAc. $\mathrm{L}^{-1}$.

$\mathrm{O}$ pico de maior concentração de matéria orgânica afluente ocorreu às $18 \mathrm{~h}$ (747 mg.L $\left.\mathrm{L}^{-1}\right)$ devido à alimentação do sistema. As concentrações de matéria orgânica 
em termos de DQO bruta variaram ao longo do tempo de operação do reator na faixa de 577 a $747 \mathrm{mg} . \mathrm{L}^{-1}$ (em torno de $77 \%$ ) no afluente e na faixa de 300 a $475 \mathrm{mg} . \mathrm{L}^{-1}$ (em torno de 63\%) no efluente. A eficiência média de remoção de matéria orgânica foi de $46 \pm 12 \%$, com variação de $20 \%$ a $60 \%$ para DQO bruta. Porém a média da remoção de matéria orgânica não é representativa nesse perfil, uma vez que a eficiência de remoção de matéria orgânica do sistema foi prejudicada pelo arraste de sólidos suspensos totais e de sólidos suspensos voláteis no efluente no período de $9 \mathrm{~h}$ às $12 \mathrm{~h}$.

A carga orgânica imposta ao reator variou de 0,22 a 0,29 kgDQO.d $\mathrm{d}^{-1}$, obtendo-se média de aproximadamente $0,25 \mathrm{kgDQO} \cdot \mathrm{d}^{-1}$. A taxa de carregamento orgânica resultou na faixa variável de 1,38 a 1,79 $\mathrm{kgDQO} \cdot \mathrm{m}^{-3} \mathrm{~d}^{-1}$, com valor médio de aproximadamente $1,53 \mathrm{kgDQO} \cdot \mathrm{m}^{-3} \mathrm{~d}^{-1}$.

As concentrações de matéria orgânica em termos de DQO filtrada variaram de $371 \mathrm{mg} . \mathrm{L}^{-1}$ a $464 \mathrm{mg} . \mathrm{L}^{-1}$ para o afluente e de $117 \mathrm{mg} . \mathrm{L}^{-1}$ a $236 \mathrm{mg} . \mathrm{L}^{-1}$ para o efluente do reator. A eficiência de remoção de DQO filtrada variou de $43 \%$ a $70 \%$, obtendo-se um valor médio de $60 \pm 11 \%$ (Figura 17.e).

As concentrações de sólidos suspensos totais resultaram em faixa variável igual de 52 a $169 \mathrm{mg} . \mathrm{L}^{-1}$ para o afluente e de 27 a $140 \mathrm{mg} . \mathrm{L}^{-1}$ para o efluente do reator, com eficiência média de remoção de aproximadamente $48 \pm 22 \%$. Para as concentrações de sólidos suspensos voláteis foram obtidos valores variáveis na faixa de 46 a $142 \mathrm{mg} . \mathrm{L}^{-1}$ para o afluente e de 24 a $123 \mathrm{mg} . \mathrm{L}^{-1}$ para o efluente do reator, com eficiência média de remoção de $46 \pm 21 \%$. É possível notar pela Figura 17.f e Figura 17.g que houve arraste de sólidos suspensos totais e de sólidos suspensos voláteis aproximadamente no período das $9 \mathrm{~h}$ às $12 \mathrm{~h}$, que prejudicou a eficiência do sistema.

Como foi necessário realizar a alimentação do sistema às $18 \mathrm{~h}$, o arraste de sólidos pode ter sido causado devido à falta de volume de substrato nos tanques de armazenamento e a maior concentração de SST e de SSV depositada no fundo dos tanques de armazenamento nesse período. No período das $18 \mathrm{~h}$ às $21 \mathrm{~h}$, a concentração de SST e de SSV permaneceu elevada no afluente, provavelmente devido à agitação promovida após a alimentação dos tanques de armazenamento do substrato. 
A parcela volátil dos sólidos suspensos em relação à concentração de sólidos suspensos totais correspondeu a aproximadamente $88 \%$ no afluente e $92 \%$ no efluente do reator.

As concentrações de nitrogênio total (N-NTK) foram de $59 \mathrm{mg} . \mathrm{L}^{-1} \mathrm{e}$ $56 \mathrm{mg} . \mathrm{L}^{-1}$ nas amostras compostas do afluente e do efluente, respectivamente. As amostras compostas do afluente e do efluente resultaram em $36 \mathrm{mg} . \mathrm{L}^{-1}$ e $29 \mathrm{mg} . \mathrm{L}^{-1}$ para nitrogênio amoniacal $\left(\mathrm{N}-\mathrm{NH}_{4}{ }^{+}\right)$.

A Tabela 23 apresenta o resumo dos resultados obtidos durante a realização do perfil de amostragem temporal no dia $309^{\circ}$ de operação do reator. Nesse perfil foram coletadas amostras do afluente e do efluente do sistema a cada $3 \mathrm{~h}$ durante o período total de $24 \mathrm{~h}$.

Tabela 23. Resumo dos resultados obtidos no perfil de 24 h do $309^{\circ}$ dia de operação (ETAPA II - TDH = 10h; Vasc $=0,23$ m.h ${ }^{-1}$ )

\begin{tabular}{|c|c|c|c|c|c|c|c|c|c|c|}
\hline \multirow[t]{2}{*}{ PARÂMETROS } & \multicolumn{5}{|c|}{ AFLUENTE } & \multicolumn{5}{|c|}{ EFLUENTE } \\
\hline & $\mathrm{N}$ & $\bar{X}$ & DP & Min & Máx & $\mathrm{N}$ & $\bar{X}$ & $\mathrm{DP}$ & Min & Máx \\
\hline$\overline{\mathrm{pH}}$ & 8 & 6,3 & 0,0 & 6,2 & 6,3 & 8 & 7,0 & 0,1 & 6,8 & 7,0 \\
\hline Temperatura do líquido $\left({ }^{\circ} \mathrm{C}\right)$ & - & - & - & - & - & 8 & 24,1 & 1,0 & 23,0 & 25,5 \\
\hline Alc parcial $\left(\mathrm{mgCaCO} 3 . \mathrm{L}^{-1}\right)$ & 8 & 90 & 15 & 70 & 103 & 8 & 193 & 7 & 183 & 202 \\
\hline Alc total $\left(\mathrm{mgCaCO} 3 \cdot \mathrm{L}^{-1}\right)$ & 8 & 214 & 12 & 194 & 226 & 8 & 271 & 18 & 228 & 281 \\
\hline Alc bicarbonato (mgCaCO3. $\left.\mathrm{L}^{-1}\right)$ & 8 & 131 & 17 & 105 & 151 & 8 & 247 & 18 & 206 & 259 \\
\hline Ácidos voláteis (mgHAC.L $\left.\mathrm{L}^{-1}\right)$ & 8 & 116 & 16 & 102 & 141 & 8 & 33 & 7 & 28 & 49 \\
\hline DQO bruta $\left(\mathrm{mg} \cdot \mathrm{L}^{-1}\right)$ & 8 & 639 & 62 & 577 & 747 & 8 & 341 & 60 & 300 & 475 \\
\hline \% remoção DQO bruta & - & - & - & - & - & - & 46 & - & - & - \\
\hline DQO filtrada $\left(\mathrm{mg} \cdot \mathrm{L}^{-1}\right)$ & 8 & 415 & 39 & 371 & 464 & 8 & 168 & 52 & 117 & 236 \\
\hline $\mathrm{SST}\left(\mathrm{mg} \cdot \mathrm{L}^{-1}\right)$ & 8 & 113 & 36 & 52 & 169 & 8 & 92 & 34 & 27 & 140 \\
\hline $\operatorname{SSV}\left(m g \cdot L^{-1}\right)$ & 8 & 99 & 31 & 46 & 142 & 8 & 84 & 31 & 24 & 123 \\
\hline $\mathrm{SSF}\left(\mathrm{mg} \cdot \mathrm{L}^{-1}\right)$ & 8 & 14 & 7 & 4 & 27 & 8 & 8 & 6 & 2 & 17 \\
\hline
\end{tabular}

\subsection{INFLUÊNCIA DA VARIAÇÃO SENOIDAL CÍCLICA DA VAZÃo MÉDIA AFLUENTE EM 40\% NO COMPORTAMENTO DO REATOR UASB (160 L) - ETAPA III;}

A etapa III compreendeu o período entre os dias $320^{\circ}$ dia e $348^{\circ}$ de operação do reator, com aplicação de variação senoidal cíclica da vazão média afluente em $40 \%$.

Dois perfis de amostragem temporal foram realizados nos dias $320^{\circ}\left(1^{\circ}\right.$ dia da aplicação da variação senoidal de $40 \%$ ) e $344^{\circ}$ de operação. Foi escolhido um 
intervalo de tempo de duas semanas entre os perfis, pois esperava-se que a introdução de uma perturbação mantida continuamente, fosse absorvida pelo reator ao alcançar um novo estado de equilíbrio dinâmico aparente. O comportamento do reator foi avaliado por meio de determinação dos mesmos parâmetros de controle das etapas anteriores.

A Figura 18 apresenta as variações temporais de $\mathrm{pH}$, alcalinidade a bicarbonato, concentração de ácidos voláteis, DQO de amostras brutas, DQO de amostras filtradas, concentração de sólidos suspensos totais (SST), concentração de sólidos suspensos voláteis (SSV) e relação SSV/SST.

Os valores médios obtidos para temperatura ambiente e para a temperatura do efluente (líquido) do reator variaram de $27,0 \pm 2,0^{\circ} \mathrm{C}$ e $26,0 \pm 1,1^{\circ} \mathrm{C}$, respectivamente.

Os valores de $\mathrm{pH}$ variaram de 6,3 a 6,5 nas amostras do afluente e de 6,9 a 7,2 nas amostras do efluente do reator (Figura 18.a).

Os valores de alcalinidade total variaram de 183 a $325 \mathrm{mg} \mathrm{CaCO} 3 . \mathrm{L}^{-1}$ no afluente e de 217 a $339 \mathrm{mg} \mathrm{CaCO}_{3} \mathrm{~L}^{-1}$ no efluente do reator. Os valores obtidos para a alcalinidade a bicarbonato variaram de 85 a $173 \mathrm{mg} \mathrm{CaCO}_{3} \cdot \mathrm{L}^{-1}$ para o afluente e de 124 a $295 \mathrm{mg} \mathrm{CaCO} 3 . \mathrm{L}^{-1}$ para o efluente do reator. A capacidade de tamponamento do meio pôde ser observada pelos valores superiores de alcalinidade total e de alcalinidade a bicarbonato no efluente em relação àqueles observados no afluente do sistema (Figura 18.b).

A concentração média de ácidos voláteis foi de $57 \pm 29 \mathrm{mgHAc} . \mathrm{L}^{-1}$ no efluente do sistema, com concentração variável na faixa de 32 a $131 \mathrm{mgHAc}^{-1}$. Às $10 \mathrm{~h}$ houve um pico máximo de ácidos voláteis no efluente com concentração de 131 mgHAc. $\mathrm{L}^{-1}$. Porém após esse horário o reator apresentou capacidade de recuperação das condições iniciais com o tamponamento do sistema. 


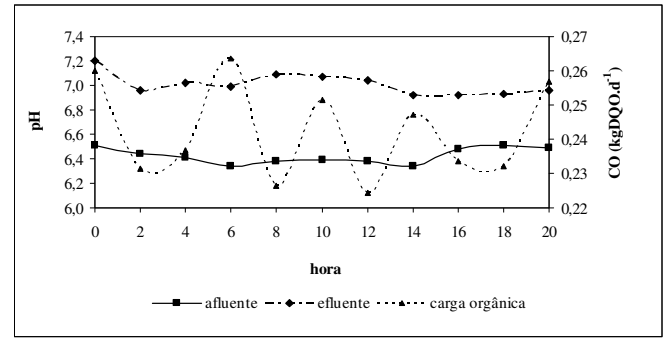

a)

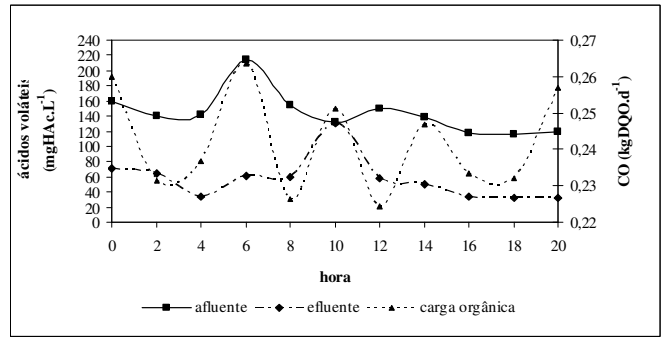

c)

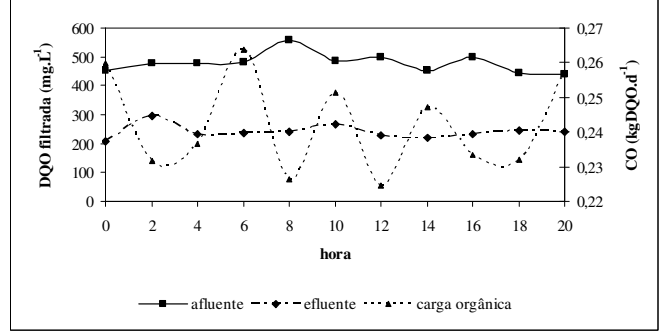

e)

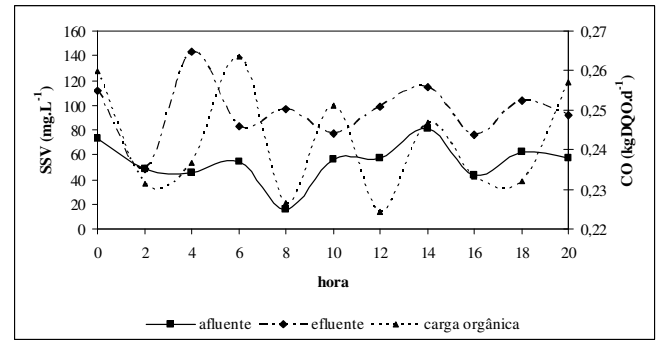

g)

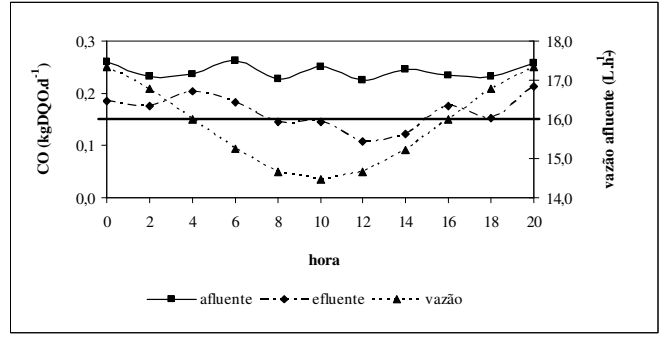

i)

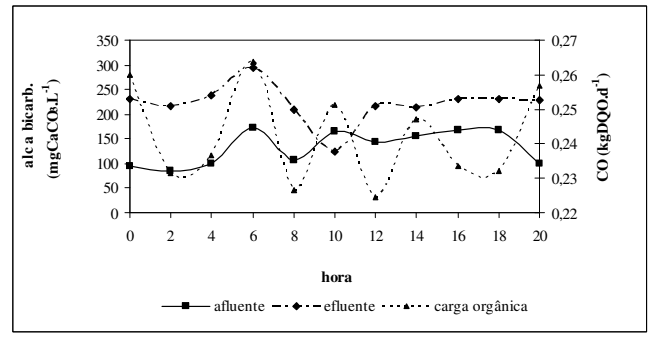

b)

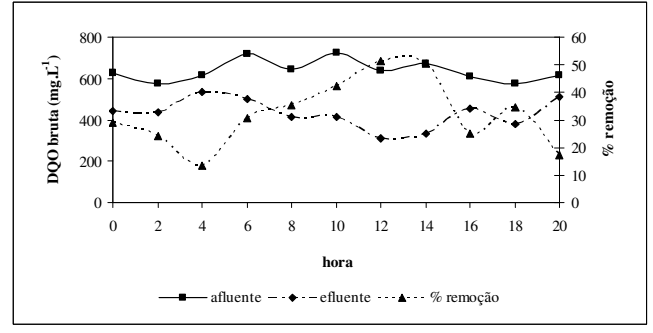

d)

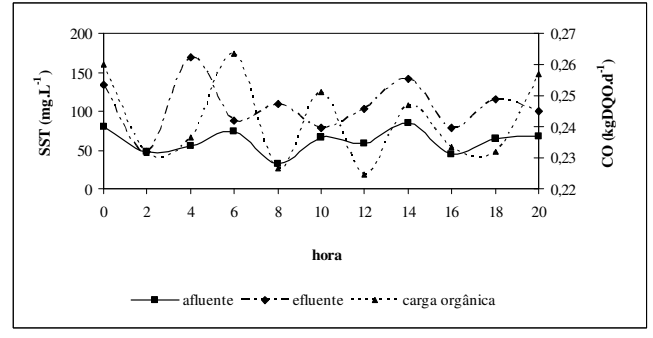

f)

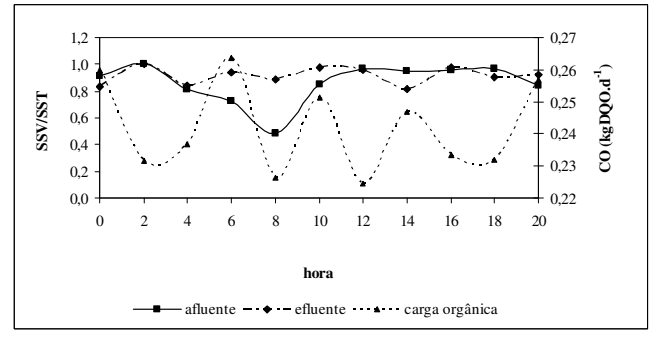

h)

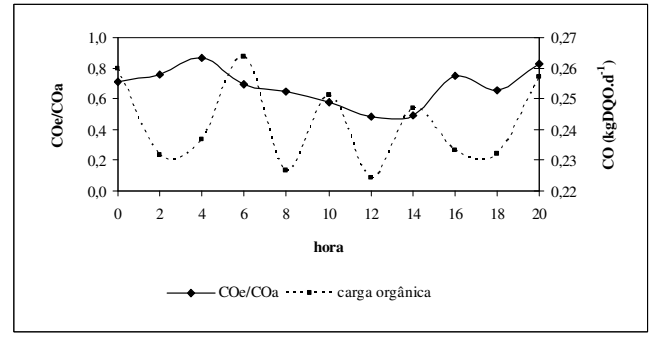

j)

Figura 18. Resultados do perfil de $24 \mathrm{~h}$ de amostragem temporal do reator no dia $320^{\circ}$ a) $\mathrm{pH}$, b) alcalinidade a bicarbonato, c) concentração de ácidos voláteis, d) DQO bruta, e) DQO filtrada, f) concentração de SST, g) concentração de SSV, h) relação SSV/SST, i) carga orgânica, j) relação COe/COa (ETAPA III TDH e Vasc $=$ variável). $* 0$ tempo 0 dos gráficos corresponde às $8 \mathrm{~h}$. 
As concentrações de matéria orgânica em termos de DQO bruta variaram ao longo do tempo de operação do reator na faixa de 575 a $724 \mathrm{mg} . \mathrm{L}^{-1}$ no afluente e de 309 a 533 mg. $\mathrm{L}^{-1}$ no efluente. A eficiência média de remoção de matéria orgânica foi de $32 \pm 12 \%$, com variação de $14 \%$ a $52 \%$ para DQO bruta. Porém a média da remoção de matéria orgânica não é representativa nesse perfil, uma vez que a eficiência de remoção de matéria orgânica do sistema foi prejudicada pelo arraste de sólidos suspensos totais e de sólidos suspensos voláteis no efluente durante todo o período de realização dos ensaios.

As concentrações de matéria orgânica em termos de DQO filtrada resultaram nas faixas variáveis de $439 \mathrm{mg} . \mathrm{L}^{-1}$ a $560 \mathrm{mg} . \mathrm{L}^{-1}$ para o afluente e de $207 \mathrm{mg} . \mathrm{L}^{-1}$ a $296 \mathrm{mg} . \mathrm{L}^{-1}$ para o efluente do reator. A eficiência de remoção de DQO filtrada

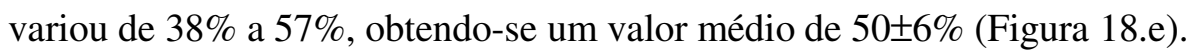

As concentrações de sólidos suspensos totais resultaram em faixa variável igual de 16 a $85 \mathrm{mg} . \mathrm{L}^{-1}$ para o afluente e de 48 a $170 \mathrm{mg} . \mathrm{L}^{-1}$ para o efluente do reator. Para as concentrações de sólidos suspensos voláteis foram obtidos valores variáveis na faixa de 33 a $81 \mathrm{mg} . \mathrm{L}^{-1}$ para o afluente e de 48 a $143 \mathrm{mg} . \mathrm{L}^{-1}$ para o efluente do reator. É possível notar pela Figura 18.f e Figura 18.g que houve arraste de sólidos suspensos totais e de sólidos suspensos voláteis em todo período de realização do perfil, provavelmente devido à formação de "bolsões" resultante do acúmulo de biogás no manto de lodo. Esse fenômeno também foi verificado por Mahmoud et al. (2003). Outro fator que pode ter contribuído para o arraste de sólidos no efluente foi a aplicação da variação senoidal da vazão média afluente de $40 \%$, onde pode ter ocorrido a expansão do manto de lodo devido ao aumento da velocidade ascensional de fluxo nos períodos de valores máximos da vazão afluente.

Grotenhuis (1992) ${ }^{10}$ apud Aiyuk et al. (2006) ressaltaram que o aumento do arraste de sólidos no efluente pode ocorrer devido à ruptura (quebra) do grânulo do lodo anaeróbio usado no tratamento de esgoto doméstico de baixa concentração. Mesmo com a suplementação do reator com esgoto sintético, esse fato pode ter

\footnotetext{
${ }^{10}$ Grotenhuis, J.T.C. (1992). Structure and stability of methanogenic granular sludge. Ph.D. Thesis. Wageningen University, Wageningen, The Netherlands.
} 
ocorrido em alguns momentos da operação uma vez que não havia controle da concentração da matéria orgânica afluente.

A parcela volátil dos sólidos suspensos em relação à concentração de sólidos suspensos totais correspondeu a aproximadamente $86 \%$ no afluente e $91 \%$ no efluente do reator.

As cargas orgânicas impostas ao reator variaram de 0,22 a 0,26 kgDQO.d $\mathrm{d}^{-1}$, obtendo-se média de aproximadamente $0,24 \mathrm{kgDQO} \cdot \mathrm{d}^{-1}$. As taxas de carregamento orgânicas resultaram na faixa variável de 1,40 a 1,65 kgDQO.m $\mathrm{m}^{-3}$, com valor médio de aproximadamente $1,51 \mathrm{kgDQO} \cdot \mathrm{m}^{-3} \mathrm{~d}^{-1}$.

As concentrações de nitrogênio total (N-NTK) foram de $76 \mathrm{mg} . \mathrm{L}^{-1}$ e $70 \mathrm{mg} . \mathrm{L}^{-1}$ nas amostras medidas do afluente e do efluente, respectivamente. Não foram observadas concentrações de nitrogênio amoniacal $\left(\mathrm{N}_{-} \mathrm{NH}_{4}{ }^{+}\right)$nas amostras compostas do afluente e do efluente desse perfil de concentração temporal.

Com a realização desse perfil foi possível observar que as variações senoidais da vazão média afluente para valores inferiores e superiores a 40\%, influenciaram principalmente a eficiência de remoção de matéria orgânica do sistema.

Com a variação da vazão afluente de 17,5 L.h ${ }^{-1}$ para 16,0 L.h ${ }^{-1}$ houve diminuição de aproximadamente $15 \%$ na eficiência de remoção de matéria orgânica no período das $0 \mathrm{~h}$ às $4 \mathrm{~h}$, devido provavelmente ao arraste de sólidos. $\mathrm{O}$ mesmo comportamento foi verificado quando a vazão afluente aumentou de $16,0 \mathrm{~L}^{-1}{ }^{-1}$ para 17,5 L.h ${ }^{-1}$ no período das $16 \mathrm{~h}$ às $20 \mathrm{~h}$, com queda na eficiência de remoção de aproximadamente 17\% (Figura 18.i).

O sistema apresentou capacidade de recuperação das condições iniciais de remoção de matéria orgânica quando foi aplicada variação da vazão média afluente de $16,0 \mathrm{~L} \cdot \mathrm{h}^{-1}$ para vazão mínima de $14,5 \mathrm{~L}^{-\mathrm{h}^{-1}}$ no período das 4 h às $10 \mathrm{~h}$. É possível verificar menor amplitude entre as concentrações de sólidos suspensos totais e de sólidos suspensos voláteis no afluente e no efluente do sistema nesse período (Figura 18.f e Figura 18.g).

Após esse período, a vazão afluente foi aumentada para $16,0 \mathrm{~L} \cdot \mathrm{h}^{-1}$ até às $16 \mathrm{~h}$. Foi observado melhor comportamento do sistema na eficiência de remoção de matéria orgânica até às $14 \mathrm{~h}$, com aplicação de menores tempos de detenção hidráulica e de maiores velocidades ascensionais de fluxo. 
A Tabela 24 apresenta o resumo dos resultados obtidos durante a realização do perfil de amostragem temporal do $320^{\circ}$ dia de operação do reator. Nesse perfil foram coletadas amostras do afluente e do efluente do sistema a cada $2 \mathrm{~h}$ durante o período total de $24 \mathrm{~h}$ para que fosse possível avaliar detalhadamente a influência da variação cíclica senoidal da vazão afluente.

Tabela 24. Resumo dos resultados obtidos no perfil de $24 \mathrm{~h}$ do $320^{\circ}$ dia de operação (ETAPA III - TDH e Vasc = variável)

\begin{tabular}{|c|c|c|c|c|c|c|c|c|c|c|}
\hline \multirow[t]{2}{*}{ PARÂMETROS } & \multicolumn{5}{|c|}{ AFLUENTE } & \multicolumn{5}{|c|}{ EFLUENTE } \\
\hline & $\mathrm{N}$ & $\bar{X}$ & DP & Min & Máx & $\mathrm{N}$ & $\bar{X}$ & DP & Min & Máx \\
\hline $\mathrm{pH}$ & 11 & 6,4 & 0,1 & 6,3 & 6,5 & 11 & 7,0 & 0,1 & 6,9 & 7,2 \\
\hline Temperatura do líquido $\left({ }^{\circ} \mathrm{C}\right)$ & - & - & - & - & - & 11 & 26,0 & 1,1 & 24,0 & 27,0 \\
\hline Alc parcial $\left(\mathrm{mgCaCO} 3 . \mathrm{L}^{-1}\right)$ & 11 & 95 & 25 & 65 & 160 & 11 & 186 & 28 & 121 & 234 \\
\hline Alc total $\left(\mathrm{mgCaCO} 3 . \mathrm{L}^{-1}\right)$ & 11 & 235 & 41 & 183 & 325 & 11 & 262 & 30 & 217 & 339 \\
\hline Alc bicarbonato (mgCaCO3. $\left.\mathrm{L}^{-1}\right)$ & 11 & 133 & 35 & 85 & 173 & 11 & 221 & 40 & 124 & 295 \\
\hline Ácidos voláteis $\left(\mathrm{mgHAC} . \mathrm{L}^{-1}\right)$ & 11 & 144 & 28 & 116 & 214 & 11 & 57 & 29 & 32 & 131 \\
\hline DQO bruta $\left(\mathrm{mg} \cdot \mathrm{L}^{-1}\right)$ & 11 & 638 & 50 & 575 & 724 & 11 & 430 & 70 & 309 & 533 \\
\hline \% remoção DQO bruta & - & - & - & - & - & - & 32 & - & - & - \\
\hline DQO filtrada (mg. $\left.\mathrm{L}^{-1}\right)$ & 11 & 479 & 34 & 439 & 560 & 11 & 241 & 24 & 207 & 296 \\
\hline $\operatorname{SST}\left(\mathrm{mg} \cdot \mathrm{L}^{-1}\right)$ & 11 & 58 & 19 & 16 & 85 & 11 & 106 & 34 & 48 & 170 \\
\hline $\operatorname{SSV}\left(\mathrm{mg} \cdot \mathrm{L}^{-1}\right)$ & 11 & 57 & 14 & 33 & 81 & 11 & 95 & 25 & 48 & 143 \\
\hline $\operatorname{SSF}\left(m g . L^{-1}\right)$ & 11 & 1 & 10 & 0 & 11 & 11 & 11 & 10 & 0 & 27 \\
\hline
\end{tabular}

A Figura 19 apresenta as variações temporais de $\mathrm{pH}$, alcalinidade a bicarbonato, concentração de ácidos voláteis, DQO de amostras brutas, DQO de amostras filtradas, concentração de sólidos suspensos totais (SST), concentração de sólidos suspensos voláteis (SSV) e relação SSV/SST.

Os valores médios obtidos para temperatura ambiente e para a temperatura do efluente (líquido) do reator foram de $20,0 \pm 1,0^{\circ} \mathrm{C}$ e $21,0 \pm 1,0^{\circ} \mathrm{C}$, respectivamente.

Os valores de $\mathrm{pH}$ variaram de 6,4 a 6,6 nas amostras do afluente e de 6,9 a 7,1 nas amostras do efluente do reator (Figura 19.a).

O tamponamento do meio pôde ser observado pelos valores superiores de alcalinidade total e de alcalinidade a bicarbonato no efluente em relação àqueles obtidos no afluente do sistema (Figura 19.b). Os valores de alcalinidade total variaram de 162 a $213 \mathrm{mg} \mathrm{CaCO}{ }_{3} \cdot \mathrm{L}^{-1}$ no afluente e de 181 a $213 \mathrm{mg} \mathrm{CaCO}_{3} \mathrm{~L}^{-1}$ no efluente do reator. Os valores obtidos para a alcalinidade a bicarbonato variaram de 77 a $131 \mathrm{mg} \mathrm{CaCO} 3 . \mathrm{L}^{-1}$ para o afluente e de 140 a $192 \mathrm{mg} \mathrm{CaCO} 3 . \mathrm{L}^{-1}$ para o efluente do reator. 
A concentração média de ácidos voláteis resultou em $49 \pm 24$ mgHAc. $\mathrm{L}^{-1}$ no efluente do sistema, com concentração variável na faixa de 21 a 86 mgHAc.L $L^{-1}$. O maior pico de ácidos voláteis ocorreu às $0 \mathrm{~h}$ com concentração de aproximadamente 85 mgHAc. $\mathrm{L}^{-1}$, o qual não influenciou no comportamento do sistema.

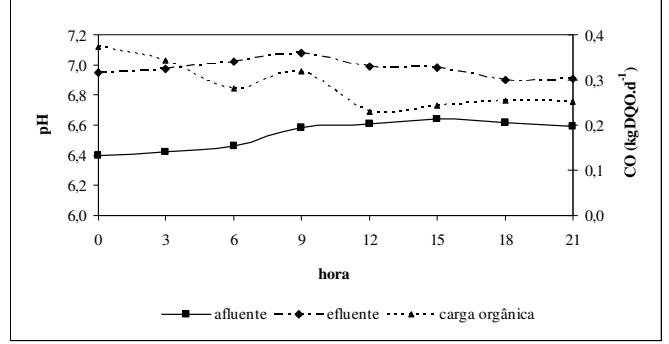

a)

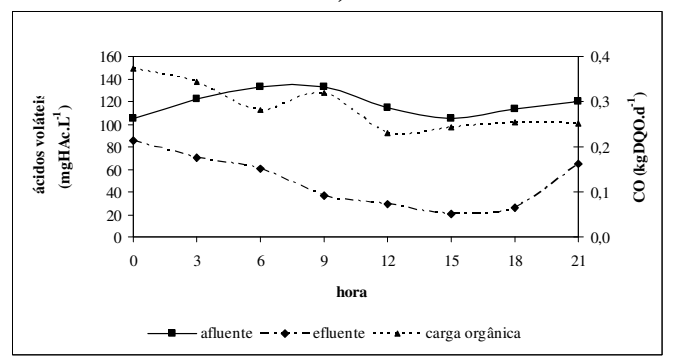

c)

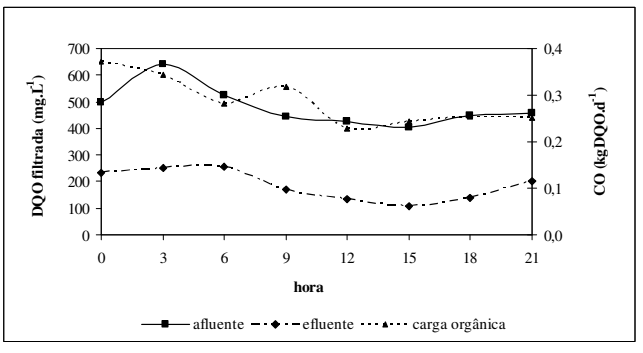

e)

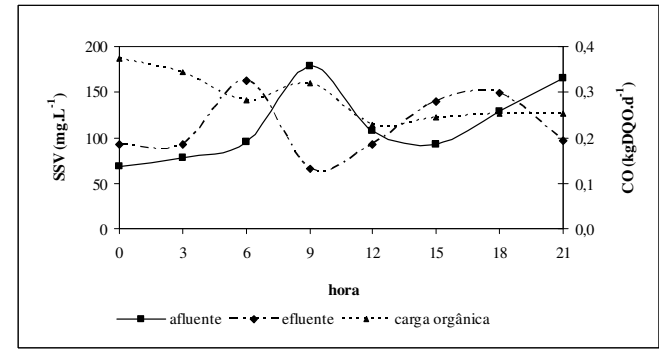

g)

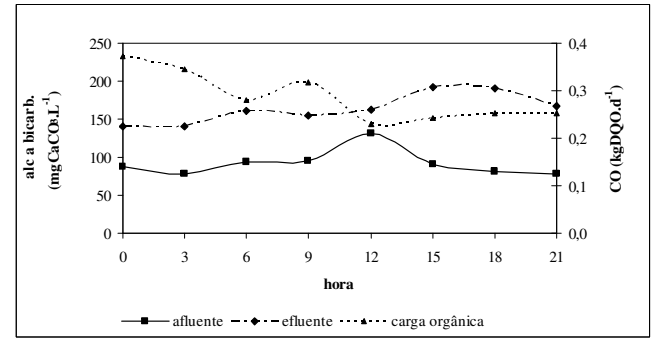

b)

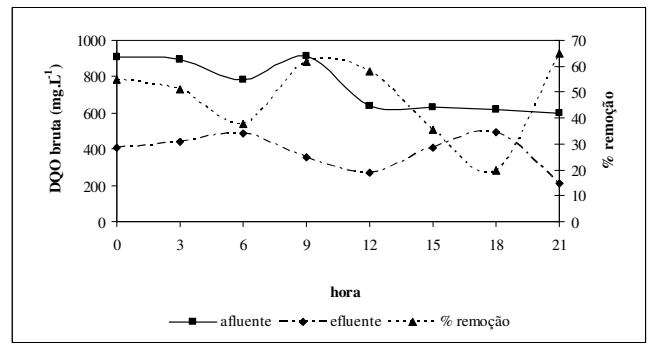

d)

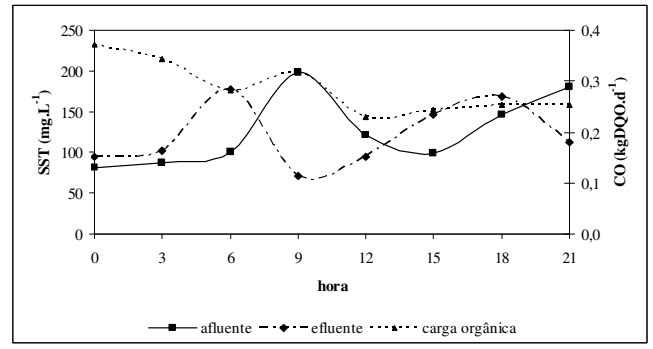

f)

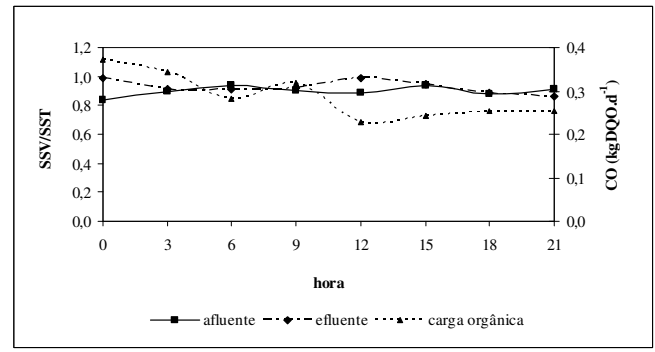

h)

Figura 19. Resultados do perfil de $24 \mathrm{~h}$ de amostragem temporal do reator do dia $344^{\circ}$ a) $\mathrm{pH}$, b) alcalinidade a bicarbonato, c) concentração de ácidos voláteis, d) DQO bruta, e) DQO filtrada, f) concentração de SST, g) concentração de SSV, h) relação SSV/SST (ETAPA III- TDH e Vasc = variável)*O tempo 0 dos gráficos corresponde às $9 \mathrm{~h}$. 
As concentrações de matéria orgânica em termos de DQO bruta variaram ao longo do tempo de operação do reator na faixa de 600 a $916 \mathrm{mg} . \mathrm{L}^{-1}$ no afluente e de 211 a 494 mg.L L $^{-1}$ no efluente. A eficiência média de remoção de matéria orgânica foi de $48 \pm 15 \%$, com variação de $20 \%$ a $65 \%$ para DQO bruta. Porém a média da remoção de matéria orgânica não é representativa nesse perfil, uma vez que a eficiência do sistema na remoção de matéria orgânica foi prejudicada pelo arraste de sólidos suspensos totais e de sólidos suspensos voláteis no efluente durante o período de realização das análises (picos às 15 h e às 24 h).

Pela Figura 19.d é possível observar que às $9 \mathrm{~h}$ do início do perfil houve aumento da concentração de matéria orgânica afluente, provavelmente devido ao arraste de material orgânico depositado no fundo dos tanques de armazenamento e na tubulação de alimentação do reator. A alimentação do reator foi realizada no horário das $0 \mathrm{~h}$ nesse perfil.

As concentrações de matéria orgânica em termos de DQO filtrada resultaram nas faixas variáveis de $404 \mathrm{mg} . \mathrm{L}^{-1}$ a $643 \mathrm{mg} . \mathrm{L}^{-1}$ para o afluente e de $106 \mathrm{mg} . \mathrm{L}^{-1}$ a $255 \mathrm{mg} . \mathrm{L}^{-1}$ para o efluente do reator. A eficiência de remoção de DQO filtrada

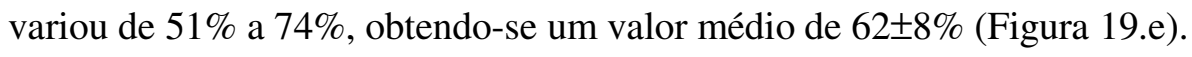

As concentrações de sólidos suspensos totais resultaram em faixa variável igual de 81 a $198 \mathrm{mg} . \mathrm{L}^{-1}$ para o afluente e de 71 a $177 \mathrm{mg} . \mathrm{L}^{-1}$ para o efluente do reator. Para as concentrações de sólidos suspensos voláteis foram obtidos valores variáveis na faixa de 68 a $178 \mathrm{mg} . \mathrm{L}^{-1}$ para o afluente e de 65 a $162 \mathrm{mg} . \mathrm{L}^{-1}$ para o efluente do reator. É possível notar pela Figura 19.f e Figura 19.g, arraste de sólidos suspensos totais e de sólidos suspensos voláteis durante a realização do perfil.

A parcela volátil dos sólidos suspensos em relação à concentração de sólidos suspensos totais correspondeu a aproximadamente $90 \%$ no afluente e $93 \%$ no efluente do reator.

As cargas orgânicas impostas ao reator variaram na faixa de 0,23 a 0,27 kgDQO. $\mathrm{d}^{-1}$, obtendo-se média de 0,29 kgDQO. $\mathrm{d}^{-1}$. As taxas de carregamento orgânicas resultaram na faixa variável de 1,43 a 2,33 $\mathrm{kgDQO} \cdot \mathrm{m}^{-3} \mathrm{~d}^{-1}$, com valor médio de $1,79 \mathrm{kgDQO} \cdot \mathrm{m}^{-3} \mathrm{~d}^{-1}$.

As concentrações de nitrogênio total (N-NTK) resultaram em 76 mg.L $\mathrm{L}^{-1}$ e $70 \mathrm{mg} . \mathrm{L}^{-1}$ nas amostras compostas do afluente e do efluente, respectivamente. Não 
foram observadas concentrações de nitrogênio amoniacal $\left(\mathrm{N}^{-\mathrm{NH}_{4}}{ }^{+}\right)$nas amostras compostas do afluente e do efluente desse perfil de concentração temporal.

A Tabela 25 apresenta o resumo dos resultados obtidos no perfil de amostragem temporal realizado no $344^{\circ}$ dia de operação. As amostras do afluente e do efluente do sistema foram coletadas a cada $3 \mathrm{~h}$ em período total de $24 \mathrm{~h}$ nesse perfil.

Tabela 25. Resumo dos resultados obtidos no perfil de 24 h do $344^{\circ}$ dia de operação (ETAPA III - TDH e Vasc = variável)

\begin{tabular}{|c|c|c|c|c|c|c|c|c|c|c|}
\hline \multirow[t]{2}{*}{ PARÂMETROS } & \multicolumn{5}{|c|}{ AFLUENTE } & \multicolumn{5}{|c|}{ EFLUENTE } \\
\hline & $\mathrm{N}$ & $\bar{X}$ & DP & Min & Máx & $\mathrm{N}$ & $\bar{X}$ & DP & Min & Máx \\
\hline $\mathrm{pH}$ & 8 & 6,5 & 0,1 & 6,4 & 6,6 & 8 & 7,0 & 0,1 & 6,9 & 7,1 \\
\hline Temperatura do líquido $\left({ }^{\circ} \mathrm{C}\right)$ & - & - & - & - & - & 8 & 21,1 & 1,2 & 20,0 & 23,0 \\
\hline Alc parcial $\left(\mathrm{mgCaCO} 3 . \mathrm{L}^{-1}\right)$ & 8 & 80 & 13 & 63 & 110 & 8 & 129 & 16 & 109 & 152 \\
\hline Alc total $\left(\mathrm{mgCaCO} 3 . \mathrm{L}^{-1}\right)$ & 8 & 176 & 19 & 162 & 213 & 8 & 199 & 12 & 181 & 213 \\
\hline Alc bicarbonato (mgCaCO3. $\left.\mathrm{L}^{-1}\right)$ & 8 & 92 & 17 & 77 & 131 & 8 & 164 & 20 & 140 & 192 \\
\hline Ácidos voláteis (mgHAC. $\left.\mathrm{L}^{-1}\right)$ & 8 & 118 & 11 & 105 & 133 & 8 & 49 & 24 & 21 & 86 \\
\hline DQO bruta $\left(\mathrm{mg} \cdot \mathrm{L}^{-1}\right)$ & 8 & 750 & 142 & 600 & 916 & 8 & 384 & 101 & 211 & 494 \\
\hline \% remoção DQO bruta & - & - & - & - & - & - & 48 & - & - & - \\
\hline DQO filtrada (mg.L $\left.\mathrm{L}^{-1}\right)$ & 8 & 480 & 76 & 404 & 643 & 8 & 186 & 57 & 106 & 255 \\
\hline SST (mg.L $\left.\mathrm{L}^{-1}\right)$ & 8 & 127 & 44 & 81 & 198 & 8 & 121 & 39 & 71 & 177 \\
\hline $\mathrm{SSV}\left(\mathrm{mg} \cdot \mathrm{L}^{-1}\right)$ & 8 & 114 & 40 & 68 & 178 & 8 & 111 & 34 & 65 & 162 \\
\hline $\mathrm{SSF}\left(\mathrm{mg} . \mathrm{L}^{-1}\right)$ & 8 & 13 & 5 & 6 & 20 & 8 & 9 & 7 & 1 & 19 \\
\hline
\end{tabular}

N: número de amostras; $\quad \bar{X}$ : média; DP: desvio padrão; Min: valor mínimo; Máx: valor máximo

Com a realização desse perfil foi possível observar que a aplicação das variações senoidais da vazão média afluente, para valores inferiores e superiores a $40 \%$, influenciaram na eficiência de remoção da matéria orgânica, quando comparada àquelas observadas nas etapas com vazão afluente constante.

Com a variação da vazão afluente máxima de $17,5 \mathrm{~L} \cdot \mathrm{h}^{-1}$ para vazão média de $16,0 \mathrm{~L} \cdot \mathrm{h}^{-1}$ no período das $9 \mathrm{~h}$ às $15 \mathrm{~h}$ houve diminuição de aproximadamente $17 \%$ na eficiência de remoção de matéria orgânica devido provavelmente ao arraste de sólidos suspensos totais e de sólidos suspensos voláteis que ocorreu nesse período. $\mathrm{O}$ mesmo comportamento foi verificado no período das $24 \mathrm{~h}$ às $27 \mathrm{~h}$ quando o reator foi submetido a aumento da vazão média afluente para o valor máximo, com queda na eficiência de remoção de aproximadamente $16 \%$.

O sistema apresentou capacidade de recuperação das condições iniciais em relação a remoção de matéria orgânica no período das 15 h às 20 h, quando foi 
aplicada variação da vazão média afluente de 16,0 L.h ${ }^{-1}$ para vazão mínima de 14,5 L.h ${ }^{-1}$ (Figura 19.f e Figura 19.g).

Após esse período com aplicação de menores tempos de detenção hidráulica e maiores velocidades ascensionais de fluxo, a vazão afluente foi aumentada até atingir seu valor médio às 24 h. Foi observado melhor comportamento do sistema em relação a eficiência de remoção de matéria orgânica até aproximadamente às $20 \mathrm{~h}$.

\subsection{INFLUÊNCIA DA VARIAÇÃO SENOIDAL CÍCLICA DA VAZÃo MÉDIA AFLUENTE EM 60\% NO COMPORTAMENTO DO REATOR UASB (160 L) - ETAPA IV;}

A etapa IV compreendeu o período do $349^{\circ}$ dia ao $370^{\circ}$ dia de operação do reator, com aplicação de variação senoidal cíclica da vazão média afluente em $60 \%$.

Nessa etapa foram realizados dois perfis de amostragem temporal com determinação dos mesmos parâmetros de controle das etapas anteriores.

Com o objetivo de avaliar a resposta dinâmica do reator submetido a primeira variação da vazão senoidal cíclica de $60 \%$, foi realizado um perfil de amostragem temporal com coleta de amostras do afluente e efluente a cada $3 \mathrm{~h}$ durante período de 24 h no $349^{\circ}$ dia de operação.

A Figura 20 apresenta as variações temporais de $\mathrm{pH}$, alcalinidade a bicarbonato, concentração de ácidos voláteis, DQO de amostras brutas, DQO de amostras filtradas, concentração de sólidos suspensos totais (SST), concentração de sólidos suspensos voláteis (SSV) e relação SSV/SST.

Os valores médios obtidos para temperatura ambiente resultaram de $20,0 \pm 1,3^{\circ} \mathrm{C}$ e para temperatura do efluente (líquido) do reator resultaram de $19,6 \pm 0,6^{\circ} \mathrm{C}$.

Os valores de $\mathrm{pH}$ variaram de 6,1 a 6,7 no afluente e de 6,6 a 7,0 no efluente do reator (Figura 20.a). 


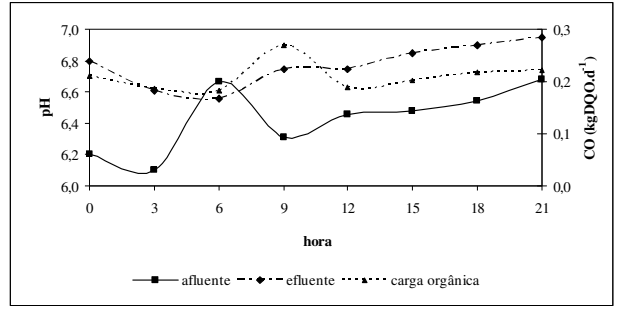

a)

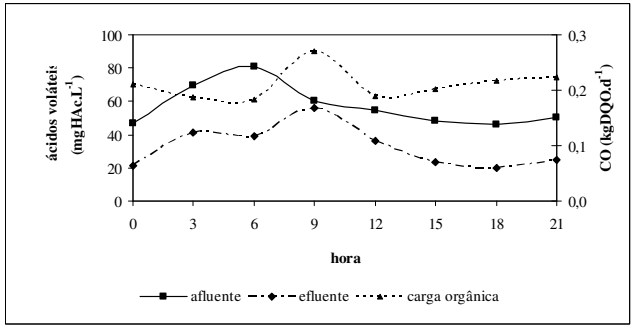

c)

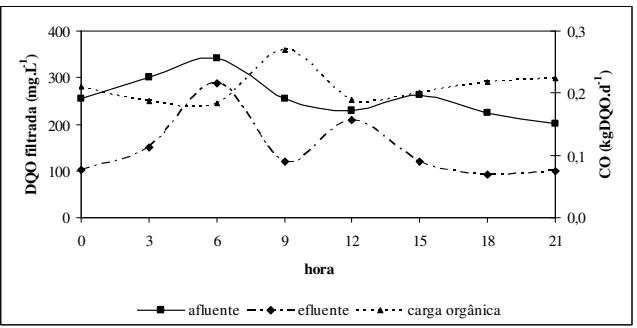

e)

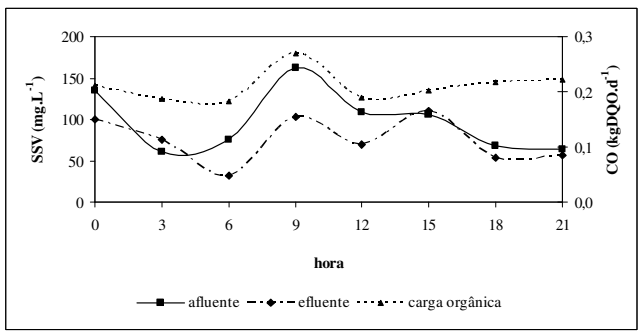

g)

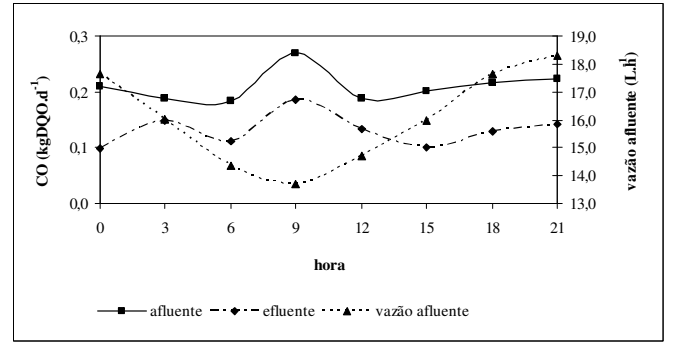

i)

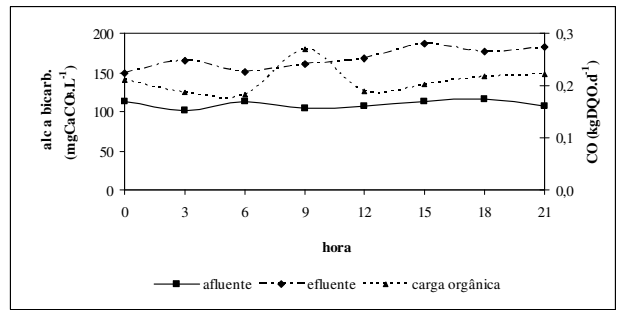

b)

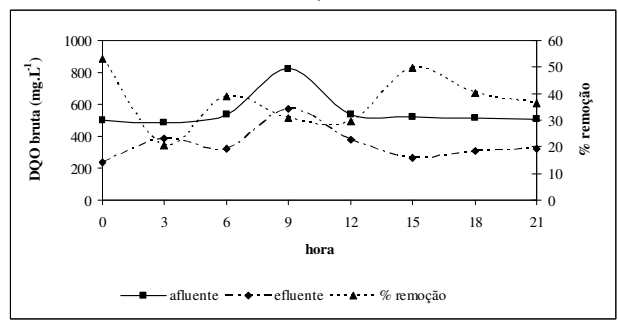

d)

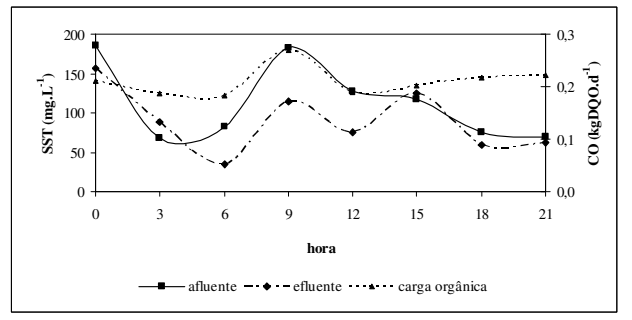

f)

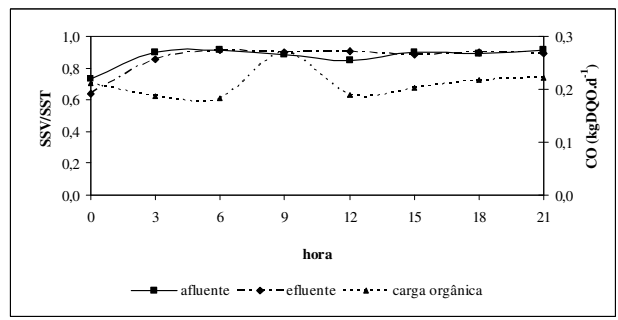

h)

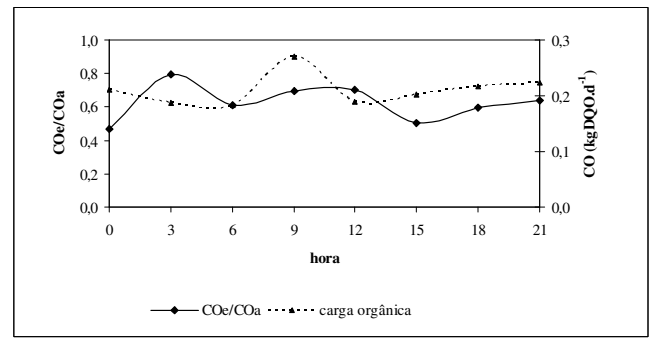

j)

Figura 20. Resultados do perfil de $24 \mathrm{~h}$ de amostragem temporal do reator no dia $349^{\circ}$ a) $\mathrm{pH}$, b) alcalinidade a bicarbonato, c) concentração de ácidos voláteis, d) DQO bruta, e) DQO filtrada, f) concentração de sólidos suspensos totais, g) concentração de sólidos suspensos voláteis, h) relação SSV/SST, i) carga orgânica, j) relação COe/COa (ETAPA IV- TDH e Vasc $=$ variável).*O tempo 0 dos gráficos corresponde às $9 \mathrm{~h}$. 
Os valores de alcalinidade total variaram de 125 a $144 \mathrm{mg} \mathrm{CaCO}_{3} \cdot \mathrm{L}^{-1}$ no afluente e de 179 a $201 \mathrm{mg} \mathrm{CaCO}_{3} \mathrm{~L}^{-1}$ no efluente do reator. Os valores obtidos para a alcalinidade a bicarbonato variaram de 101 a $116 \mathrm{mg} \mathrm{CaCO}_{3} \cdot \mathrm{L}^{-1}$ para o afluente e de 150 a $187 \mathrm{mg} \mathrm{CaCO}_{3} \cdot \mathrm{L}^{-1}$ para o efluente do reator. Ao comparar os valores obtidos para as concentrações de alcalinidade total e a bicarbonato foi possível observar que os valores do efluente foram superiores àqueles obtidos para o afluente, o que indica a capacidade de tamponamento do sistema (Figura 20.b).

A concentração média de ácidos voláteis foi de $33 \pm 13 \mathrm{mgHAc} . \mathrm{L}^{-1}$ no efluente do sistema, com concentração variável na faixa de 20 a 56 mgHAc. $\mathrm{L}^{-1}$. A degradação do substrato nos tanques de armazenamento pode ter causado o aumento da concentração de ácidos voláteis no afluente até $6 \mathrm{~h}$ de realização do perfil, pois a alimentação do sistema foi realizada após $9 \mathrm{~h}$ do início do perfil. Porém esse aumento não influenciou na estabilidade do sistema conforme observado na Figura 20.a, Figura 20.b e Figura 20.c.

As concentrações de matéria orgânica em termos de DQO bruta no afluente variaram significativamente em torno de $68 \%$ ao longo do tempo de operação do reator, atingindo picos de mínimo e de máximo iguais a $489 \mathrm{mg} . \mathrm{L}^{-1}$ e $822 \mathrm{mg} . \mathrm{L}^{-1}$, respectivamente. Essa variação foi menos acentuada no efluente, em torno de 43\%, atingindo picos de mínimo e de máximo iguais a $234 \mathrm{mg} . \mathrm{L}^{-1}$ e $569 \mathrm{mg} . \mathrm{L}^{-1}$. A eficiência média de remoção de matéria orgânica foi de $37 \pm 11 \%$, com variação de $21 \%$ a $53 \%$ para DQO bruta. Porém a média da remoção de matéria orgânica não é representativa nesse perfil, uma vez que a eficiência do sistema na remoção de matéria orgânica foi prejudicada pelo arraste de SST e de SSV no efluente durante o período de realização das análises (Figura 20.d, Figura 20.g e Figura 20.h).

As concentrações de matéria orgânica em termos de DQO filtrada variaram de $200 \mathrm{mg} . \mathrm{L}^{-1}$ a $342 \mathrm{mg} . \mathrm{L}^{-1}$ para o afluente e de $92 \mathrm{mg} . \mathrm{L}^{-1}$ a $289 \mathrm{mg} . \mathrm{L}^{-1}$ para o efluente do reator. A eficiência de remoção de DQO filtrada variou de $10 \%$ a 59\%, obtendo-se valor médio de $44 \pm 20 \%$ (Figura 20.e).

As concentrações de sólidos suspensos totais resultaram em faixa variável de 68 a $185 \mathrm{mg} . \mathrm{L}^{-1}$ para o afluente e de 35 a $157 \mathrm{mg} . \mathrm{L}^{-1}$ para o efluente do reator. Para as concentrações de sólidos suspensos voláteis foram obtidos valores variáveis na faixa de 61 a $162 \mathrm{mg} . \mathrm{L}^{-1}$ para o afluente e de 32 a $110 \mathrm{mg} . \mathrm{L}^{-1}$ para o efluente. No 
período de 0 h a 3 h após o início do perfil houve carreamento de SST e de SSV no efluente.

A parcela volátil dos sólidos suspensos em relação à concentração de sólidos suspensos totais correspondeu a aproximadamente $87 \%$ no afluente e no efluente do reator.

As cargas orgânicas impostas ao reator variaram na faixa de 0,18 a 0,27 kgDQO. $\mathrm{d}^{-1}$, obtendo-se média de 0,21 kgDQO. $\mathrm{d}^{-1}$. As taxas de carregamento orgânico resultaram na faixa variável de 1,15 a 1,69 kgDQO. $\mathrm{m}^{-3} \mathrm{~d}^{-1}$, com valor médio de $1,31 \mathrm{kgDQO} \cdot \mathrm{m}^{-3} \mathrm{~d}^{-1}$.

As concentrações de nitrogênio total (N-NTK) resultaram em 59 mg.L $\mathrm{L}^{-1}$ e $57 \mathrm{mg} . \mathrm{L}^{-1}$ nas amostras compostas do afluente e do efluente, respectivamente. Não foram medidas concentrações de nitrogênio amoniacal $\left(\mathrm{N}_{-} \mathrm{NH}_{4}{ }^{+}\right)$nas amostras compostas do afluente e do efluente desse perfil temporal de concentração.

A aplicação das variações senoidais com valores inferiores e superiores a $60 \%$ na vazão média afluente influenciou na resposta dinâmica do sistema, principalmente em relação à eficiência de remoção de matéria orgânica, que variou de $10 \%$ a $59 \%$.

A diminuição da vazão afluente de $17,6 \mathrm{~L}^{-1} \mathrm{~h}^{-1}$ para $16,0 \mathrm{~L} \cdot \mathrm{h}^{-1}$ nas três primeiras horas do perfil influenciou na eficiência de remoção de DQO bruta que diminuiu em aproximadamente $32 \%$.

No período das $3 \mathrm{~h}$ até as $6 \mathrm{~h}$ houve aumento da eficiência de remoção de DQO bruta em torno de $18 \%$, provavelmente devido a diminuição da vazão afluente de 16,0 L.h ${ }^{-1}$ para 14,4 L.h ${ }^{-1}$. Quando a vazão afluente atingiu seu pico mínimo de 13,7 L.h ${ }^{-1}$ às 12 h, houve diminuição da eficiência de remoção de matéria orgânica em aproximadamente $10 \%$. Outro fator que pode ter contribuído para a queda da eficiência do sistema foi o aumento da concentração de matéria orgânica nessa hora com a alimentação do sistema.

O sistema apresentou capacidade de recuperação das condições iniciais de remoção de matéria orgânica no período das $12 \mathrm{~h}$ às $15 \mathrm{~h}$, quando a vazão aumentou de $14,7 \mathrm{~L} \cdot \mathrm{h}^{-1}$ para $16,0 \mathrm{~L} \cdot \mathrm{h}^{-1}$. 
Porém após esse período a eficiência de remoção de DQO no sistema diminuiu em torno de $13 \%$, com aumento da vazão média afluente de $16,0 \mathrm{~L} \cdot \mathrm{h}^{-1}$ para 18,3 L.h ${ }^{-1}$, provavelmente devido ao arraste de SST e de SSV no efluente do reator.

A Tabela 26 apresenta o resumo dos resultados obtidos no perfil de amostragem temporal realizado no $349^{\circ}$ dia de operação.

Tabela 26. Resumo dos resultados obtidos no perfil de 24 h do $349^{\circ}$ dia de operação (ETAPA III - TDH e Vasc = variável)

\begin{tabular}{|c|c|c|c|c|c|c|c|c|c|c|}
\hline \multirow[t]{2}{*}{ PARÂMETROS } & \multicolumn{5}{|c|}{ AFLUENTE } & \multicolumn{5}{|c|}{ EFLUENTE } \\
\hline & $\mathrm{N}$ & $\bar{X}$ & DP & Min & Máx & $\mathrm{N}$ & $\bar{X}$ & DP & Min & Máx \\
\hline$\overline{\mathrm{pH}}$ & 8 & 6,4 & 0,2 & 6,1 & 6,7 & 8 & 6,8 & 0,1 & 6,6 & 7,0 \\
\hline Temperatura do líquido $\left({ }^{\circ} \mathrm{C}\right)$ & - & - & - & - & - & 8 & 19,6 & 0,6 & 18,5 & 20,0 \\
\hline Alc parcial $\left(\mathrm{mgCaCO} 3 . \mathrm{L}^{-1}\right)$ & 8 & 50 & 2 & 46 & 54 & 8 & 99 & 5 & 90 & 106 \\
\hline Alc total $\left(\mathrm{mgCaCO} 3 . \mathrm{L}^{-1}\right)$ & 8 & 133 & 6 & 125 & 144 & 8 & 189 & 7 & 179 & 201 \\
\hline Alc bicarbonato $\left(\mathrm{mgCaCO} 3 \cdot \mathrm{L}^{-1}\right)$ & 8 & 109 & 5 & 101 & 116 & 8 & 168 & 14 & 150 & 187 \\
\hline Ảcidos voláteis (mgHAC.L-1 $)$ & 8 & 57 & 13 & 45,84 & 81 & 8 & 33 & 13 & 20 & 56 \\
\hline DQO bruta $\left(\mathrm{mg} \cdot \mathrm{L}^{-1}\right)$ & 8 & 553 & 110 & 489 & 822 & 8 & 348 & 103 & 234 & 569 \\
\hline \% remoção DQO bruta & - & - & - & - & - & - & 37 & - & - & - \\
\hline DQO filtrada $\left(\mathrm{mg} . \mathrm{L}^{-1}\right)$ & 8 & 258 & 45 & 200 & 342 & 8 & 147 & 68 & 92 & 289 \\
\hline $\operatorname{SST}\left(\mathrm{mg} \cdot \mathrm{L}^{-1}\right)$ & 8 & 113 & 49 & 68 & 185 & 8 & 90 & 40 & 35 & 157 \\
\hline $\operatorname{SSV}\left(\mathrm{mg} \cdot \mathrm{L}^{-1}\right)$ & 8 & 97 & 37 & 61 & 162 & 8 & 75 & 28 & 32 & 110 \\
\hline $\operatorname{SSF}\left(\mathrm{mg} \cdot \mathrm{L}^{-1}\right)$ & 8 & 16 & 15 & 6 & 50 & 8 & 15 & 17 & 3 & 57 \\
\hline
\end{tabular}

O segundo perfil de amostragem temporal foi realizado no $370^{\circ}$ dia de operação. Para a realização desse perfil foram adotados os mesmos procedimentos do perfil anterior.

A Figura 21 apresenta as variações temporais de $\mathrm{pH}$, alcalinidade a bicarbonato, concentração de ácidos voláteis, DQO de amostras brutas, DQO de amostras filtradas, concentração de sólidos suspensos totais (SST), concentração de sólidos suspensos voláteis (SSV) e relação SSV/SST.

Os valores médios obtidos para temperatura ambiente foram de $25,0 \pm 1,4^{\circ} \mathrm{C}$ e para temperatura do efluente (líquido) do reator de $24,0 \pm 1,0^{\circ} \mathrm{C}$.

Os valores de $\mathrm{pH}$ variaram de 6,3 a 6,5 no afluente e de 6,6 a 7,0 no efluente do reator (Figura 21.a). 


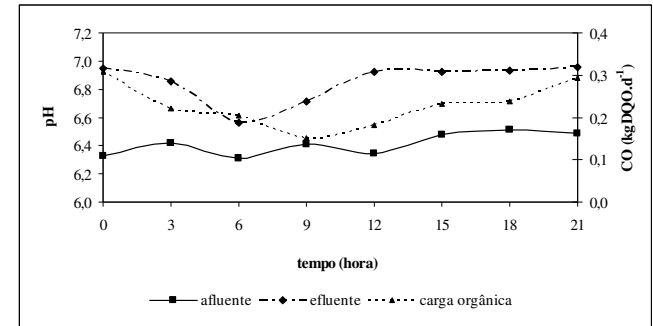

a)

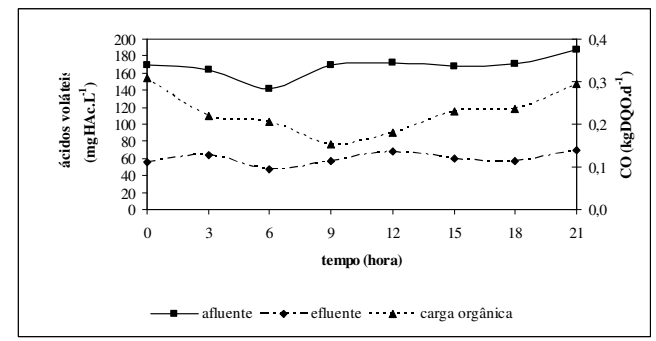

c)

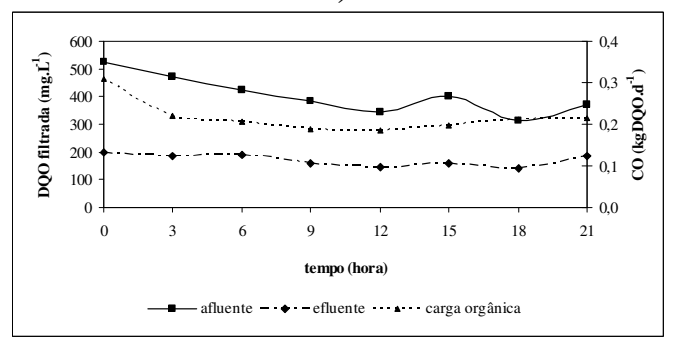

e)

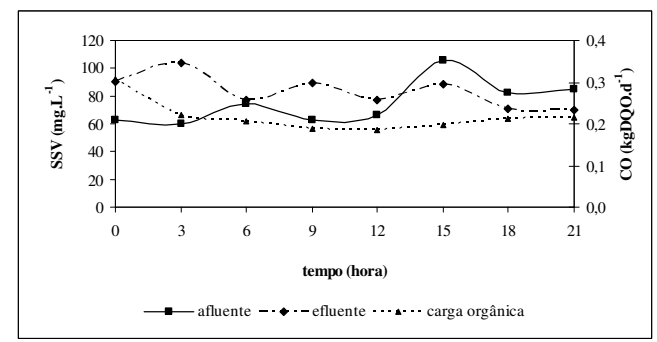

g)

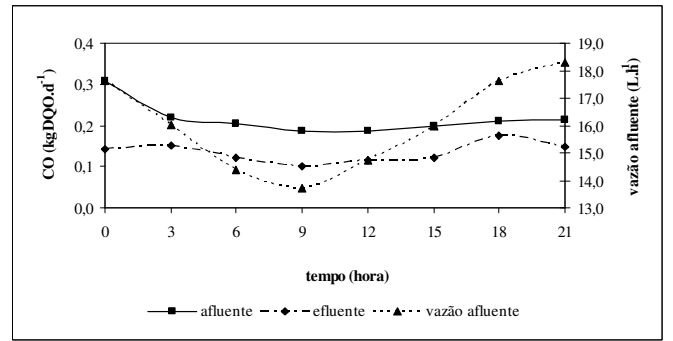

i)

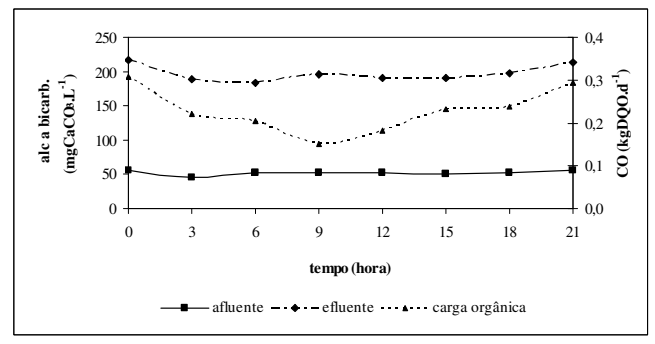

b)

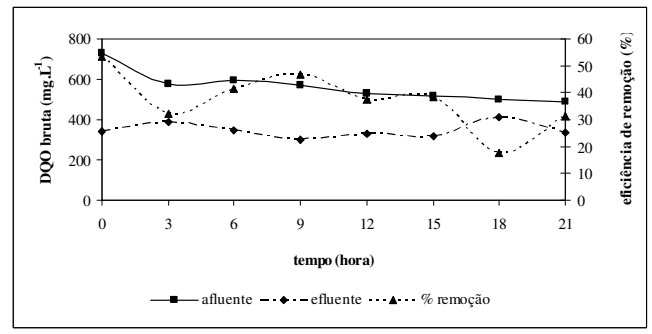

d)

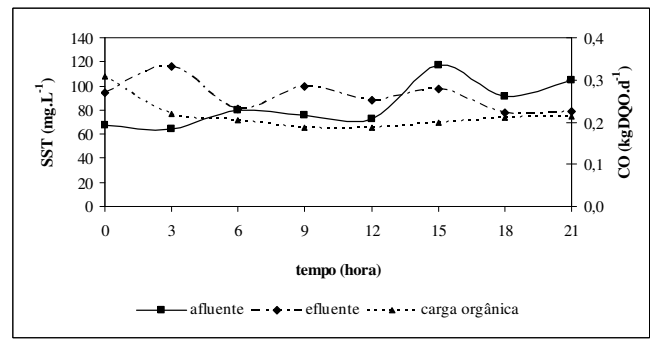

f)

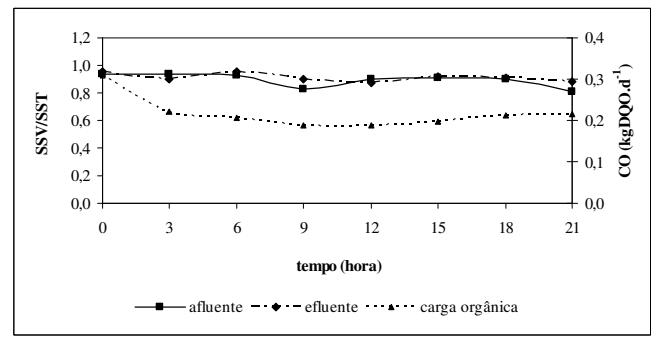

h)

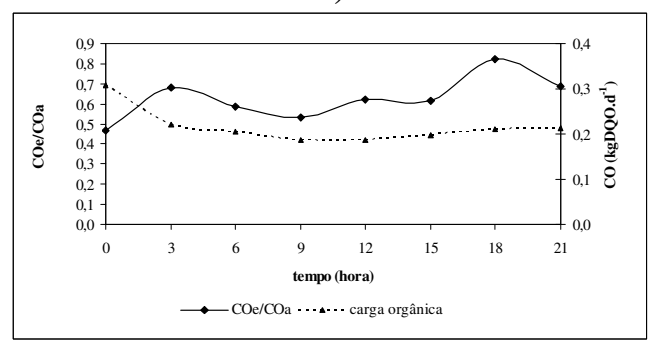

j)

Figura 21. Resultados do perfil de $24 \mathrm{~h}$ de amostragem temporal do reator do dia $370^{\circ}$ a) $\mathrm{pH}$, b) alcalinidade a bicarbonato, c) concentração de ácidos voláteis, d) DQO bruta, e) DQO filtrada, f) concentração de sólidos suspensos totais, g) concentração de sólidos suspensos voláteis, h) relação SSV/SST $($ ETAPA IV - TDH e Vasc $=$ variável). *O tempo 0 dos gráficos corresponde às $9 h$. 
Os valores de alcalinidade total variaram de 158 a $195 \mathrm{mg} \mathrm{CaCO} 3 . \mathrm{L}^{-1}$ no afluente e de 218 a $263 \mathrm{mg} \mathrm{CaCO}_{3} \mathrm{~L}^{-1}$ no efluente do reator. Os valores obtidos para a alcalinidade a bicarbonato variaram de 46 a $57 \mathrm{mg} \mathrm{CaCO}_{3} \cdot \mathrm{L}^{-1}$ para o afluente e de 184 a $216 \mathrm{mg} \mathrm{CaCO}_{3} \cdot \mathrm{L}^{-1}$ para o efluente do reator. Os valores obtidos para as concentrações de alcalinidade total e a bicarbonato no efluente foram superiores àqueles obtidos para o afluente, o que indica a capacidade de tamponamento do sistema (Figura 21.b).

A concentração média de ácidos voláteis foi de $60 \pm 7 \mathrm{mgHAc} . \mathrm{L}^{-1}$ no efluente do sistema, com concentração variável na faixa de 47 a 70 mgHAc. $\mathrm{L}^{-1}$.

A concentração de matéria orgânica em termos de DQO bruta no afluente variou em torno de $49 \%$ ao longo do tempo de operação do reator, atingindo picos de mínimo e de máximo iguais a 487 mg.L $\mathrm{L}^{-1}$ e 729 mg.L $\mathrm{L}^{-1}$, respectivamente. Essa variação foi menos acentuada no efluente, em torno de $35 \%$, atingindo picos de mínimo e de máximo iguais a $303 \mathrm{mg} . \mathrm{L}^{-1}$ e $411 \mathrm{mg} . \mathrm{L}^{-1}$. A eficiência média de remoção de matéria orgânica foi de $37 \pm 11 \%$, com variação de $18 \%$ a 53\% para DQO bruta.

As concentrações de matéria orgânica em termos de DQO filtrada variaram de $314 \mathrm{mg} . \mathrm{L}^{-1}$ a $527 \mathrm{mg} . \mathrm{L}^{-1}$ (em torno de 67\%) para o afluente e de $141 \mathrm{mg} . \mathrm{L}^{-1}$ a 199 mg.L. $L^{-1}$ (em torno de 40\%) para o efluente do reator. A eficiência de remoção de DQO filtrada variou de $50 \%$ a $62 \%$, obtendo-se um valor médio de $58 \pm 4 \%$ (Figura 21.e).

A média da eficiência de remoção de matéria orgânica não foi representativa nesse perfil, uma vez que a resposta do reator foi prejudicada pelo arraste de sólidos no efluente (Figura 21.d; Figura 21.g; Figura 21.h).

As cargas orgânicas impostas ao reator variaram na faixa de 0,19 a 0,31 kgDQO. $\mathrm{d}^{-1}$, obtendo-se média de 0,22 kgDQO. $\mathrm{d}^{-1}$. As taxas de carregamento orgânico resultaram na faixa variável de 1,17 a 1,93 $\mathrm{kgDQO} . \mathrm{m}^{-3} \mathrm{~d}^{-1}$, com valor médio de $1,35 \mathrm{kgDQO} \cdot \mathrm{m}^{-3} \mathrm{~d}^{-1}$.

As concentrações de sólidos suspensos totais resultaram em faixa variável de 64 a 117 mg. $\mathrm{L}^{-1}$, com variação de aproximadamente $82 \%$ para o afluente e de 78 a $116 \mathrm{mg} . \mathrm{L}^{-1}$, com variação de $48 \%$ para o efluente do reator. Para as concentrações de sólidos suspensos voláteis foram obtidos valores variáveis na faixa de 60 a 
$106 \mathrm{mg} . \mathrm{L}^{-1}$, com variação de $76 \%$ para o afluente e de 70 a $104 \mathrm{mg} . \mathrm{L}^{-1}$, com variação de $48 \%$ para o efluente do reator.

A parcela volátil dos sólidos suspensos em relação à concentração de sólidos suspensos totais correspondeu a aproximadamente $89 \%$ no afluente e $91 \%$ no efluente do reator.

É possível observar pela Figura 21.f e Figura 21.g que no período de 0 h a 3 h após o início do perfil houve o maior carreamento de sólidos, provavelmente devido a aplicação de variação senoidal de $60 \%$ da vazão média afluente.

Concentrações de nitrogênio total (N-NTK) e de nitrogênio amoniacal $\left(\mathrm{N}-\mathrm{NH}_{4}{ }^{+}\right)$não foram detectadas nas amostras compostas do afluente e do efluente desse perfil temporal.

A aplicação das variações senoidais com valores inferiores e superiores a $60 \%$ na vazão média afluente influenciou a resposta dinâmica do sistema, principalmente a eficiência de remoção de matéria orgânica, que variou de $18 \%$ a $53 \%$.

A variação da vazão afluente de $18,3 \mathrm{~L} \cdot \mathrm{h}^{-1}$ para $16,0 \mathrm{~L} \cdot \mathrm{h}^{-1}$ nas três primeiras horas do perfil influenciou na eficiência de remoção de DQO bruta que diminuiu em aproximadamente $21 \%$, provavelmente devido ao arraste de sólidos no efluente.

No período das $3 \mathrm{~h}$ até as $9 \mathrm{~h}$ houve um aumento da eficiência de remoção de DQO bruta em torno de $15 \%$, provavelmente devido a diminuição da vazão afluente de $16,0 \mathrm{~L} \cdot \mathrm{h}^{-1}$ para $13,7 \mathrm{~L} \cdot \mathrm{h}^{-1}$. No período das $9 \mathrm{~h}$ às $15 \mathrm{~h}$ houve diminuição da eficiência de remoção de matéria orgânica em aproximadamente 10\%, com o aumento da vazão afluente de $13,7 \mathrm{~L} \cdot \mathrm{h}^{-1}$ para $16,0 \mathrm{~L} \cdot \mathrm{h}^{-1}$. Com o aumento da vazão afluente de $16,0 \mathrm{~L} . \mathrm{h}^{-1}$ para $17,6 \mathrm{~L} \cdot \mathrm{h}^{-1}$ no período das $15 \mathrm{~h}$ às $18 \mathrm{~h}$ houve queda na eficiência do sistema.

O sistema apresentou capacidade de recuperação das condições iniciais de remoção de matéria orgânica no período das $3 \mathrm{~h}$ às $9 \mathrm{~h}$, quando foi aplicada variação da vazão de 16,0 L.h ${ }^{-1}$ para 14,7 L.h . $^{-1}$

A Tabela 27 apresenta o resumo dos resultados obtidos no perfil de amostragem temporal realizado no $370^{\circ}$ dia de operação. 
Tabela 27. Resumo dos resultados obtidos no perfil de 24 h do $370^{\circ}$ dia de operação (ETAPA III - TDH e Vasc = variável)

\begin{tabular}{|c|c|c|c|c|c|c|c|c|c|c|}
\hline \multirow[t]{2}{*}{ PARÂMETROS } & \multicolumn{5}{|c|}{ AFLUENTE } & \multicolumn{5}{|c|}{ EFLUENTE } \\
\hline & $\mathrm{N}$ & $\bar{X}$ & DP & Min & Máx & $\mathrm{N}$ & $\bar{X}$ & DP & Min & Máx \\
\hline $\mathrm{pH}$ & 8 & 6,4 & 0,1 & 6,3 & 6,5 & 8 & 6,9 & 0,1 & 6,6 & 7,0 \\
\hline Temperatura do líquido $\left({ }^{\circ} \mathrm{C}\right)$ & - & - & - & - & - & 8 & 24,0 & 1,0 & 22,5 & 25,0 \\
\hline Alc parcial $\left(\mathrm{mgCaCO} 3 . \mathrm{L}^{-1}\right)$ & 8 & 68 & 5 & 63 & 75 & 8 & 165 & 17 & 138 & 185 \\
\hline Alc total $\left(\mathrm{mgCaCO} 3 . \mathrm{L}^{-1}\right)$ & 8 & 181 & 11 & 158 & 195 & 8 & 240 & 14 & 218 & 263 \\
\hline Alc bicarbonato (mgCaCO3. $\left.\mathrm{L}^{-1}\right)$ & 8 & 52 & 3 & 46 & 57 & 8 & 197 & 12 & 184 & 216 \\
\hline Ácidos voláteis $\left(\mathrm{mgHAC} . \mathrm{L}^{-1}\right)$ & 8 & 168 & 13 & 142 & 188 & 8 & 60 & 7 & 47 & 70 \\
\hline DQO bruta $\left(\mathrm{mg} \cdot \mathrm{L}^{-1}\right)$ & 8 & 562 & 77 & 487 & 729 & 8 & 347 & 36 & 303 & 411 \\
\hline \% remoção DQO bruta & - & - & - & - & - & - & 40 & - & - & - \\
\hline DQO filtrada (mg.L $\left.\mathrm{L}^{-1}\right)$ & 8 & 404 & 69 & 314 & 527 & 8 & 170 & 21 & 141 & 199 \\
\hline SST $\left(m g . L^{-1}\right)$ & 8 & 84 & 19 & 64 & 117 & 8 & 92 & 13 & 78 & 116 \\
\hline $\mathrm{SSV}\left(\mathrm{mg} \cdot \mathrm{L}^{-1}\right)$ & 8 & 75 & 16 & 60 & 106 & 8 & 84 & 12 & 70 & 104 \\
\hline SSF $\left(m g . L^{-1}\right)$ & 8 & 9 & 5 & 4 & 20 & 8 & 8 & 3 & 4 & 12 \\
\hline
\end{tabular}

\subsection{COMPARAÇÃO ENTRE AS ETAPAS DE OPERAÇÃO}

Com o objetivo de avaliar o comportamento do reator UASB quando submetido a variações senoidais cíclicas de $40 \%$ e $60 \%$ da vazão média afluente foram analisadas:

- a estabilidade do pH/alcalinidade nas variações cíclicas de vazão;

- a capacidade do reator em amortecer a variação cíclica senoidal imposta (eficiência de remoção de matéria orgânica);

- a variabilidade da qualidade do efluente;

- a capacidade de recuperação das condições iniciais.

Apesar de terem sido realizados 8 perfis de amostragem temporal ao longo de todo o experimento, apenas o perfil que apresentou melhores resultados em cada etapa foi escolhido para efeito de comparação entre as etapas de operação do reator.

Os perfis escolhidos correspondem ao $304^{\circ}$ (etapa II), $344^{\circ}$ (etapa III) e $370^{\circ}$ (etapa IV) dia de operação do reator, ou seja, com aplicação de vazão média afluente constante e igual a 16,0 L.h ${ }^{-1}$, variação senoidal cíclica de $40 \%$ e de $60 \%$ da vazão afluente, respectivamente, e após o reator ter absorvido o impacto da introdução da variação da vazão de $40 \%$ e de $60 \%$.

A Tabela 28 apresenta o resumo dos resultados obtidos durante a realização dos perfis de amostragem temporal dos dias $304^{\circ}, 344^{\circ}$ e $370^{\circ}$ de operação do reator. 
Tabela 28. Resumo dos resultados obtidos nos perfis de 24 h dos dias $304^{\circ}, 344^{\circ}$ e $370^{\circ}$ de operação (ETAPAS I, II e III)

\begin{tabular}{|c|c|c|c|c|c|c|c|c|c|c|c|c|c|c|c|c|c|c|c|c|c|c|c|c|c|}
\hline \multirow[t]{3}{*}{ PARÅMETROS } & & \multicolumn{8}{|c|}{ Qméd $=16,0$ L.h-1; TDH $=10 \mathrm{~h}$} & \multicolumn{8}{|c|}{$\mathrm{Q}=40 \% *$ Qméd; $\mathrm{TDH}=$ var. } & \multicolumn{8}{|c|}{$\mathrm{Q}=60 \% *$ Qméd; $\mathrm{TDH}=$ var. } \\
\hline & & \multicolumn{4}{|c|}{ AFLUENTE } & \multicolumn{4}{|c|}{ EFLUENTE } & \multicolumn{4}{|c|}{ AFLUENTE } & \multicolumn{4}{|c|}{ EFLUENTE } & \multicolumn{4}{|c|}{ AFLUENTE } & \multicolumn{4}{|c|}{ EFLUENTE } \\
\hline & $\mathrm{N}$ & $\overline{\bar{X}}$ & $\overline{\mathrm{DP}}$ & $\overline{M i n}$ & Máx & $\overline{\bar{X}}$ & DP & Min & Máx & $\overline{\bar{X}}$ & $\overline{D P}$ & $\overline{M i n}$ & Máx & $\bar{X}$ & $\mathrm{DP}$ & $\operatorname{Min}$ & Máx & $\bar{X}$ & DP & Min & Máx & $\bar{X}$ & $\overline{D P}$ & $\operatorname{Min}$ & Máx \\
\hline $\mathrm{pH}$ & 8 & 6,3 & 0,1 & 6,2 & 6,4 & 6,9 & 0,1 & 6,8 & 7,1 & 6,5 & 0,1 & 6,4 & 6,6 & 7,0 & 0,1 & 6,9 & 7,1 & 6,4 & 0,1 & 6,3 & 6,5 & 6,9 & 0,1 & 6,6 & 7,0 \\
\hline Temperatura do líquido $\left({ }^{\circ} \mathrm{C}\right)$ & - & - & - & - & - & 23,9 & 1,0 & 22,0 & 25,0 & & - & - & - & 21,1 & 1,2 & 20,0 & 23,0 & - & - & - & - & 24,0 & 1,0 & 22,5 & 25,0 \\
\hline Alc parcial $\left(\mathrm{mgCaCO} 3 \cdot \mathrm{L}^{-1}\right)$ & 8 & 65 & 5 & 59 & 73 & 179 & 10 & 168 & 195 & 80 & 13 & 63 & 110 & 129 & 16 & 109 & 152 & 68 & 5 & 63 & 75 & 165 & 17 & 138 & 185 \\
\hline Alc total $\left(\mathrm{mgCaCO} 3 \cdot \mathrm{L}^{-1}\right)$ & 8 & 196 & 8 & 184 & 206 & 261 & 19 & 244 & 295 & 176 & 19 & 162 & 213 & 199 & 12 & 181 & 213 & 181 & 11 & 158 & 195 & 240 & 14 & 218 & 263 \\
\hline Alc bicarb. (mgCaCO3. $\left.\mathrm{L}^{-1}\right)$ & 8 & 84 & 20 & 52 & 117 & 231 & 18 & 211 & 261 & 92 & 17 & 77 & 131 & 164 & 20 & 140 & 192 & 52 & 3 & 46 & 57 & 197 & 12 & 184 & 216 \\
\hline Ácidos voláteis $\left(\mathrm{mgHAC} . \mathrm{L}^{-1}\right)$ & 8 & 145 & 28 & 103 & 196 & 41 & 10 & 26 & 54 & 118 & 11 & 105 & 133 & 49 & 24 & 21 & 86 & 168 & 13 & 142 & 188 & 60 & 7 & 47 & 70 \\
\hline DQO bruta $\left(\mathrm{mg} \cdot \mathrm{L}^{-1}\right)$ & 8 & 693 & 127 & 588 & 909 & 267 & 62 & 207 & 360 & 750 & 142 & 600 & 916 & 384 & 101 & 211 & 494 & 562 & 77 & 487 & 729 & 347 & 36 & 303 & 411 \\
\hline \% remoção DQO bruta & - & & - & - & - & 61 & - & - & - & - & - & - & - & 48 & - & - & - & - & - & - & & 40 & - & - & - \\
\hline DQO filtrada (mg. $\left.\mathrm{L}^{-1}\right)$ & 8 & 502 & 69 & 426 & 595 & 134 & 30 & 99 & 189 & 480 & 76 & 404 & 643 & 186 & 57 & 106 & 255 & 404 & 69 & 314 & 527 & 170 & 21 & 141 & 199 \\
\hline $\operatorname{SST}\left(\mathrm{mg} \cdot \mathrm{L}^{-1}\right)$ & 8 & 105 & 24 & 78 & 145 & 72 & 20 & 50 & 120 & 127 & 44 & 81 & 198 & 121 & 39 & 71 & 177 & 84 & 19 & 64 & 117 & 92 & 13 & 78 & 116 \\
\hline $\operatorname{SSV}\left(\mathrm{mg} \cdot \mathrm{L}^{-1}\right)$ & 8 & 99 & 22 & 77 & 139 & 63 & 24 & 21 & 109 & 114 & 40 & 68 & 178 & 111 & 34 & 65 & 162 & 75 & 16 & 60 & 106 & 84 & 12 & 70 & 104 \\
\hline $\operatorname{SSF}\left(m g . L^{-1}\right)$ & 8 & 6 & 5 & 0 & 14 & 9 & 9 & 3 & 29 & 13 & 5 & 6 & 20 & 9 & 7 & 1 & 19 & 9 & 5 & 4 & 20 & 8 & 3 & 4 & 12 \\
\hline
\end{tabular}

$\mathrm{Na}$ Figura 22 podem ser observadas as variações temporais de $\mathrm{pH}$, alcalinidade a bicarbonato, concentração de ácidos voláteis, DQO de amostras brutas, concentração de sólidos suspensos (SS) e produção de metano $\left(\mathrm{CH}_{4}\right)$.

$\mathrm{O}$ reator apresentou comportamento estável quanto ao $\mathrm{pH}$, com valores variáveis de 6,2 a 6,6 no afluente e de 6,6 a 7,1 no efluente (Figura 22.a), apesar da aplicação da variação da vazão afluente.

Os valores de alcalinidade total variaram de 158 a $213 \mathrm{mg} \mathrm{CaCO}_{3} \cdot \mathrm{L}^{-1}$ no afluente e de 181 a $295 \mathrm{mg} \mathrm{CaCO}_{3} \mathrm{~L}^{-1}$ no efluente do reator. Os valores obtidos para a alcalinidade a bicarbonato variaram de 46 a $131 \mathrm{mg} \mathrm{CaCO}_{3} \cdot \mathrm{L}^{-1}$ para o afluente e de 140 a $261 \mathrm{mg} \mathrm{CaCO}_{3} \cdot \mathrm{L}^{-1}$ para o efluente do reator. Os valores obtidos para as concentrações de alcalinidade total e a bicarbonato no efluente foram superiores àqueles obtidos para o afluente em todas as etapas de operação do reator. Esses valores indicaram a capacidade de tamponamento do sistema mesmo quando submetido a variações cíclicas da vazão afluente (Figura 22.b).

As concentrações de ácidos voláteis no efluente resultaram em valores inferiores a 90 mgHAc. $\mathrm{L}^{-1}$ nas três etapas de operação. Foi possível observar o acúmulo de ácidos no efluente com a aplicação das variações senoidais cíclicas de vazão, principalmente nos períodos de aumento da vazão média para máxima (Figura 22.c). 


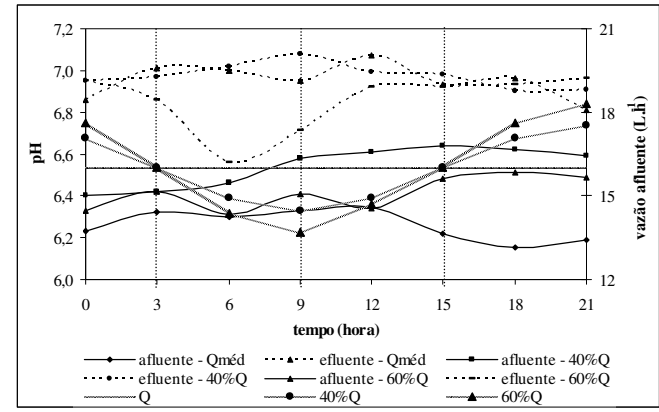

a)

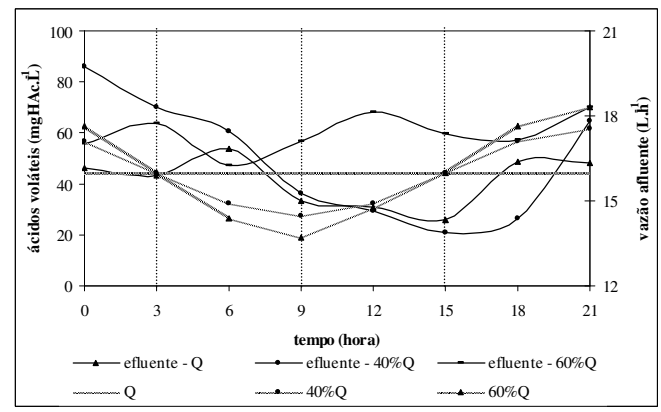

c)

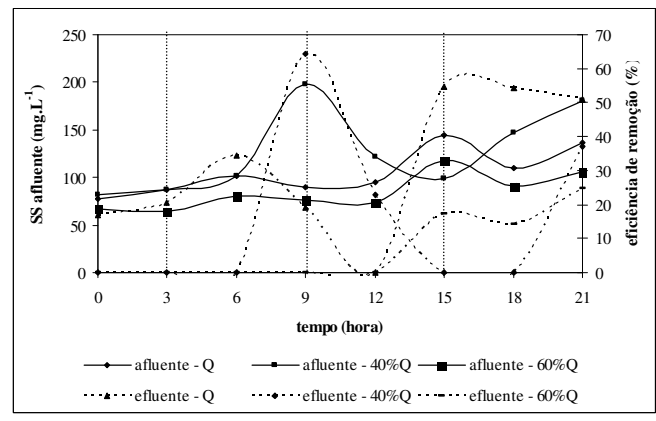

e)

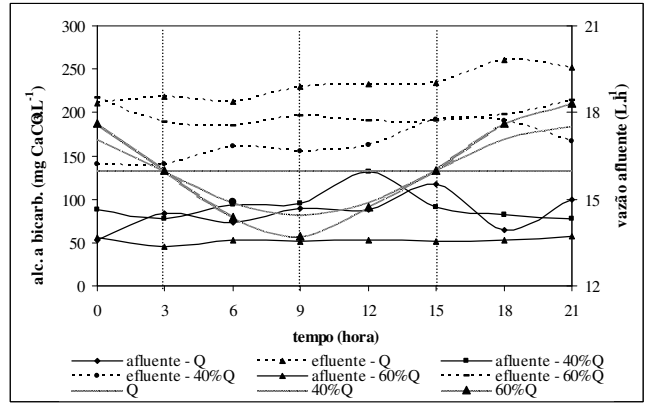

b)

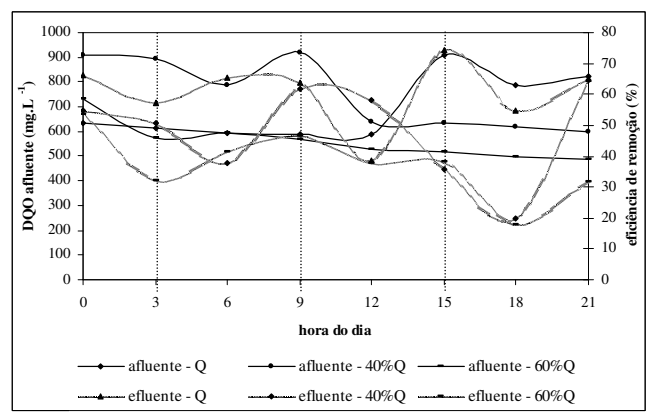

d)

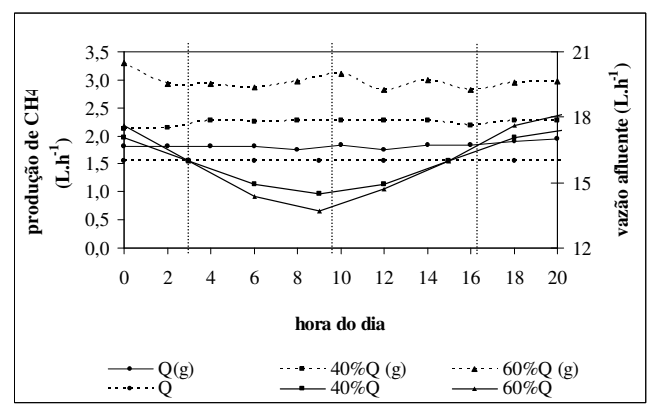

f)

Figura 22. Comparação entre os perfis de $24 \mathrm{~h}$ de amostragem temporal do reator operado com vazão média afluente (Qméd) e submetido a variações de vazão de $40 \%(40 \% *$ Qméd) e de $60 \%(60 \% *$ Qméd $)$. a) $\mathrm{pH}$, b) alcalinidade a bicarbonato, c) concentração de ácidos voláteis, d) DQO afluente, e) concentração de sólidos suspensos, f) produção de gás metano $\left(\mathrm{CH}_{4}\right)$. *O tempo 0 dos gráficos corresponde às $9 \mathrm{~h}$; (a), (e) e (g) correspondem a afluente, efluente e gás.

O aumento das concentrações de ácidos voláteis pode ter ocorrido devido a maior velocidade ascensional de fluxo, que acarretou em menor tempo de contato entre o substrato e a biomassa para a realização da metanogênese. Lew et al. (2004) e 
Leitão (2004) também observaram maiores concentrações de ácidos voláteis na operação de reatores UASB com tempos de detenção hidráulica reduzidos.

Pela Figura 22.f é possível observar similar produção de gás metano quando o reator foi operado com vazão média afluente constante e quando submetido a variação cíclica de $40 \%$ da vazão média afluente. Isso pode ter ocorrido por não ter havido tempo suficiente para o aumento (crescimento) da população de arquéias metanogênicas que consumissem o excesso de ácidos voláteis produzidos pelos microrganismos acidogênicos.

A produção de gás metano foi de aproximadamente $1,83 \mathrm{~L} \cdot \mathrm{h}^{-1}$ para o reator operado com vazão média afluente constante de 16 L.h ${ }^{-1}$ e 2,24 L.h ${ }^{-1}$ quando submetido a variação cíclica de $40 \%$ da vazão afluente. A maior produção de metano de 2,97 L.h ${ }^{-1}$ foi verificada quando o reator foi submetido a variação cíclica de $60 \%$ da vazão afluente, provavelmente pelo fato dos microrganismos já estarem mais adaptados às variações impostas.

A eficiência de remoção de DQO bruta diminuiu aproximadamente $13 \%$ e $21 \%$ com a aplicação das variações senoidais cíclicas da vazão média afluente de $40 \%$ e de $60 \%$, respectivamente (Figura 22.d). A eficiência de remoção de DQO filtrada diminuiu aproximadamente $12 \%$ e $16 \%$ com a aplicação das variações senoidais de $40 \%$ e $60 \%$, respectivamente.

A eficiência do sistema foi prejudicada pelo arraste de sólidos no efluente, provavelmente pela formação dos bolsões devido ao acúmulo de biogás no manto de lodo. A eficiência de remoção de SST e de SSV diminuiu aproximadamente $31 \%$ e $36 \%$ com aplicação das variações senoidais de $40 \%$ e de $60 \%$, respectivamente. Foi possível observar também maior arraste de sólidos devido à aplicação das variações senoidais nos períodos de aumento de velocidade ascensional de fluxo (Figura 22.e).

\subsection{EXAMES MICROBIOLÓGICOS}

Conforme descrito no capítulo Material e Métodos, os exames microbiológicos das amostras de lodo coletadas do reator UASB foram realizados por microscopia ótica comum, de fluorescência e de contraste de fase. 
O lodo anaeróbio granular utilizado como inóculo para o reator UASB apresentava coloração negra, concentração de sólidos totais de aproximadamente 36 g.L $\mathrm{L}^{-1}$, concentração de sólidos totais voláteis de aproximadamente 30 g.L $\mathrm{L}^{-1}$ (em torno de $82 \%$ ) e concentração de sólidos totais fixos de aproximadamente 6 g.L.-1 (em torno de $18 \%$ ).

As amostras de lodo foram coletadas após o reator UASB ter atingido o estado de equilíbrio dinâmico aparente em cada etapa de operação para que a microbiota presente no sistema pudesse ser avaliada.

Os exames microbiológicos foram realizados em cada fase de operação do reator: antes da inoculação do reator UASB; no $286^{\circ}$ dia de operação (aplicação de vazão média afluente constante), no $342^{\circ}$ dia de operação (aplicação de variação senoidal cíclica da vazão média afluente em 40\%) e no $372^{\circ}$ dia de operação (aplicação de variação senoidal cíclica da vazão média afluente em 60\%) do reator.

Esses exames consideram as principais morfologias presentes em alguns campos das amostras de lodo de acordo com descrições da literatura técnicocientífica.

As principais morfologias observadas no inóculo do reator UASB foram semelhantes ao gênero Methanosaeta sp., cocos e vibrios semelhantes a bactérias redutoras de sulfato (Figura 23).

Hirasawa (2003) obteve as porcentagens médias de microrganismos pela técnica de hibridização in situ com sondas fluorescentes (FISH) para o Domínio Bacteria (EUB338) e para o Domínio Archaea (ARC915) iguais a 44,8 $\pm 2,7 \%$ e $59,5 \% \pm 1,8 \%$, respectivamente. As morfologias de células predominantes no inóculo detectadas pelo FISH foram bacilos, bacilos ovalados e cocos para o Domínio Bacteria e bacilos, filamentos e sarcinas para o Domínio Archaea. 


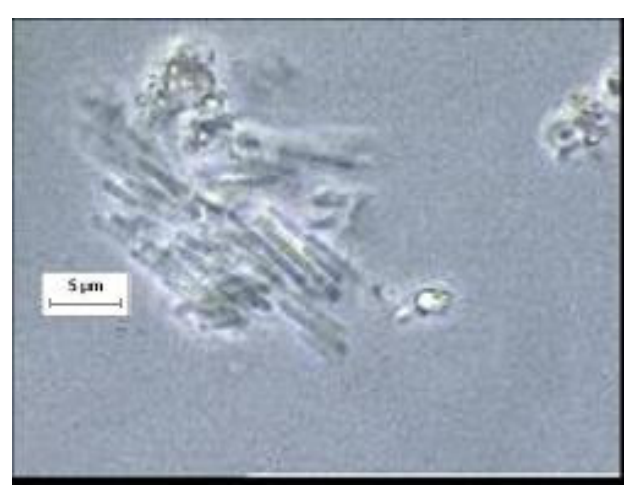

(a)

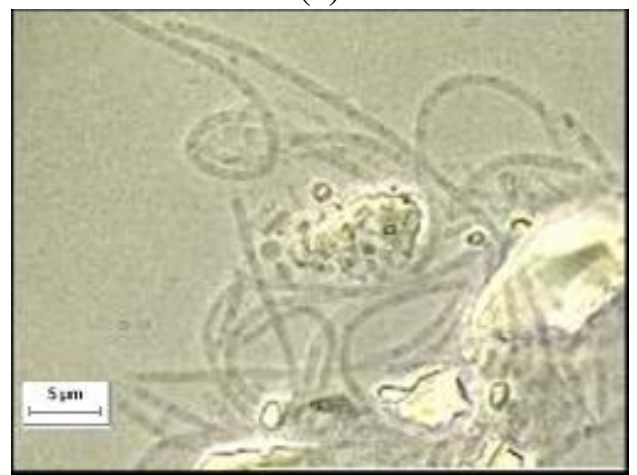

(c)

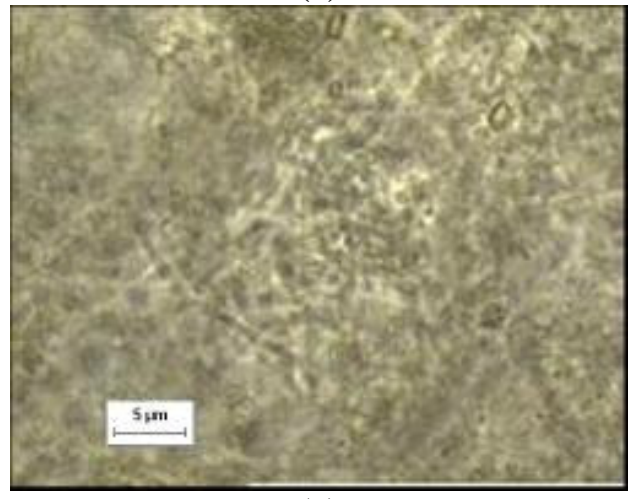

(e)

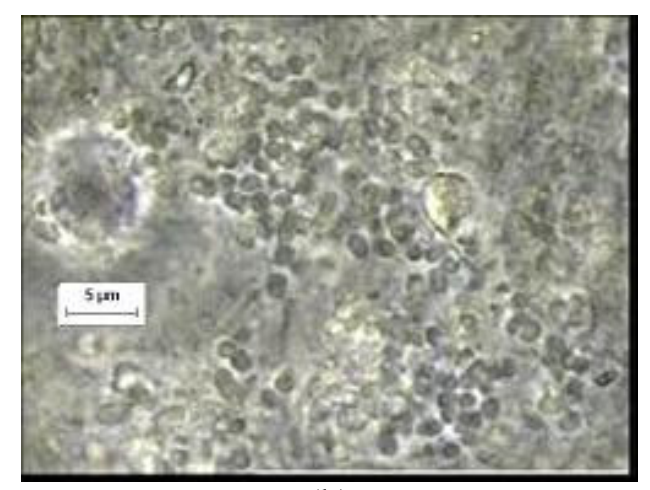

(b)

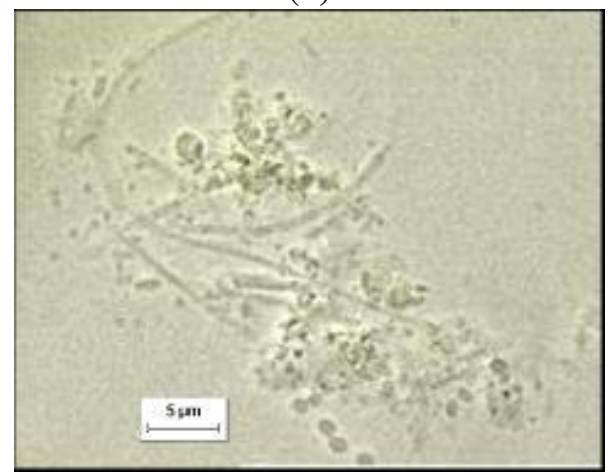

(d)

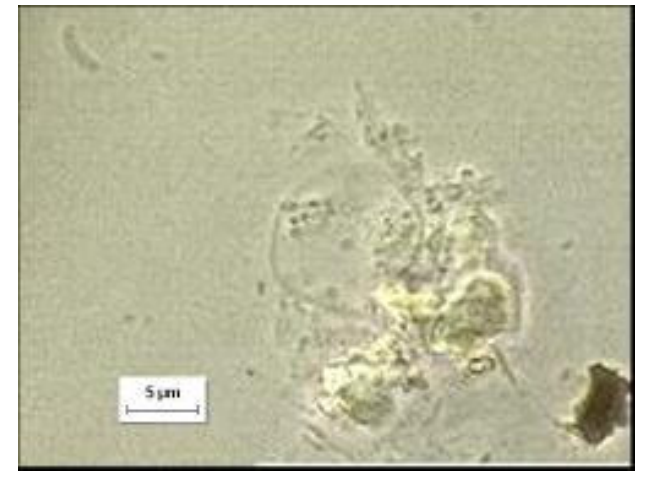

(f)

Figura 23. Fotomicrografia das principais morfologias do inóculo do reator UASB: a) arquéias metanogênicas semelhantes a Methanosaeta sp.; b) aglomerado de cocos; c), d), e) e f) bacilos, filamentos e cocos

A Figura 24 apresenta as principais morfologias observadas nas amostras de lodo coletadas no $286^{\circ}$ dia de operação do reator UASB. 


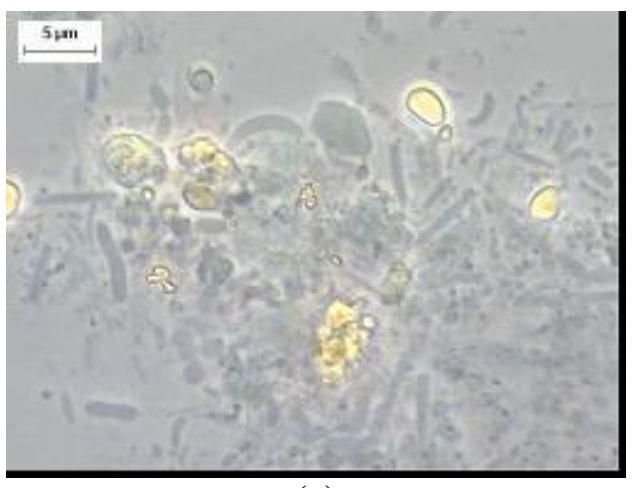

(a)

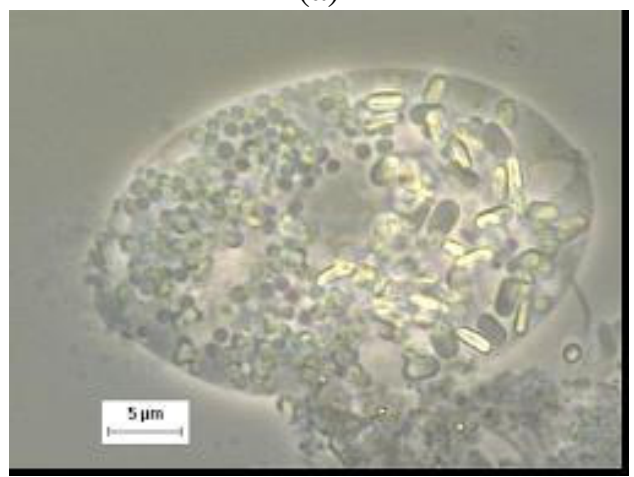

(c)

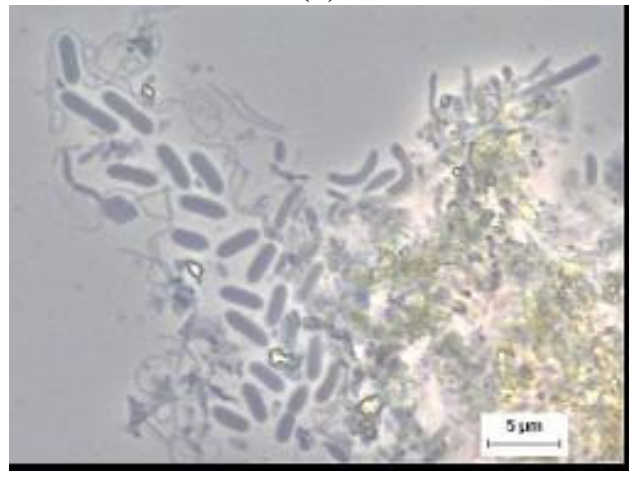

(e)

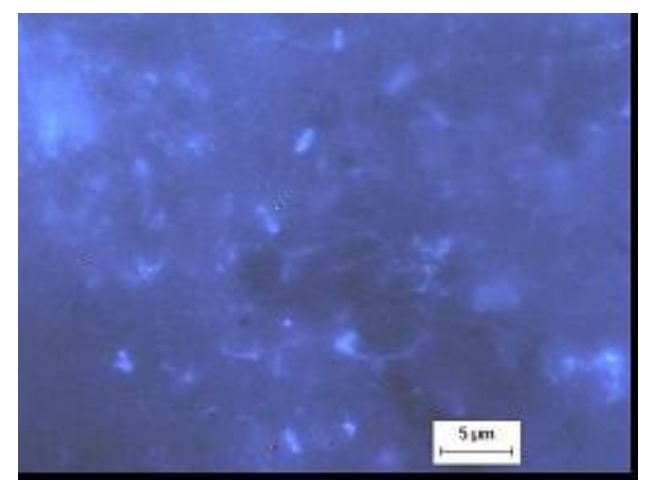

(b)

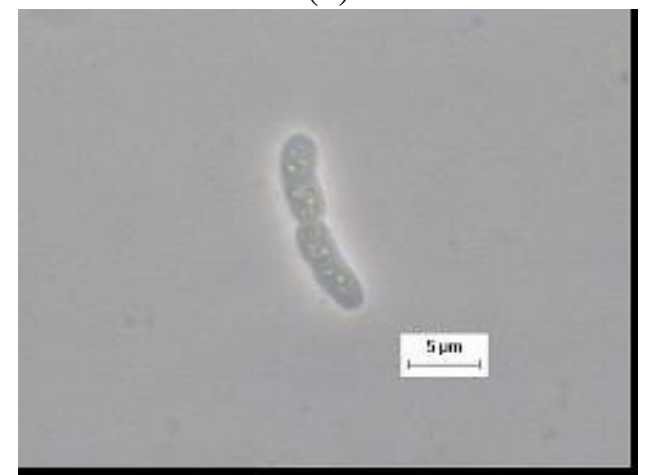

(d)

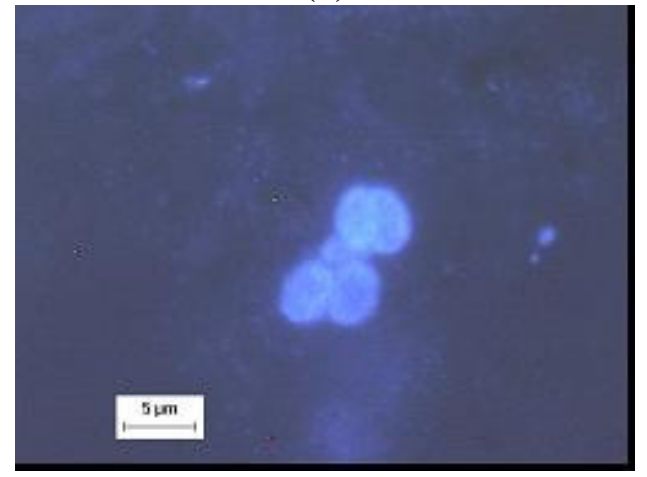

(f)

Figura 24. Fotomicrografia das principais morfologias encontrados nos grânulos do lodo no $286^{\circ}$ dia de operação do reator UASB: a) arquéias metanogênicas semelhantes a Methanosaeta sp., bacilos, vibrios, cocos; b) bacilos fluorescentes; c) aglomerado de cocos e bacilos; d) bacilos com incrustações, e) espirilo, vibrios, bacilos; f) arquéias metanogênicas semelhantes a Metanosarcina sp.

Pela Figura 24 é possível observar que as principais morfologias encontradas no $286^{\circ}$ dia de operação do reator UASB foram semelhantes ao gênero Methanosaeta sp.; bacilos, filamentos, vibrios e cocos; aglomerados de cocos e bacilos, bacilos com incrustações; espirilos; arquéias metanogênicas semelhantes ao gênero Metanosarcina sp. 
A Figura 25 apresenta as principais morfologias observadas nas amostras de lodo coletadas no $342^{\circ}$ dia de operação do reator UASB.

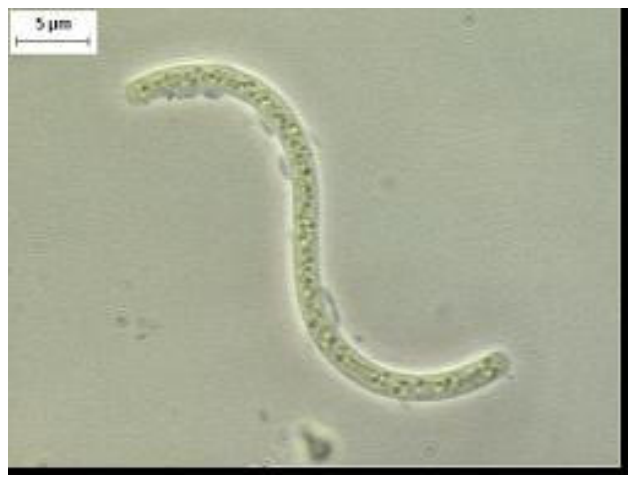

(a)

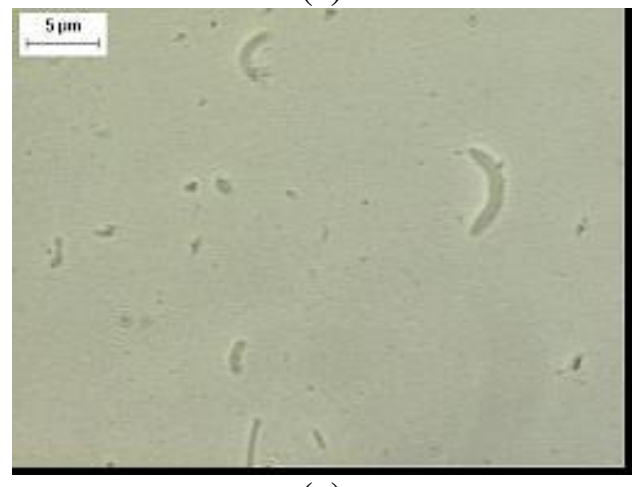

(c)

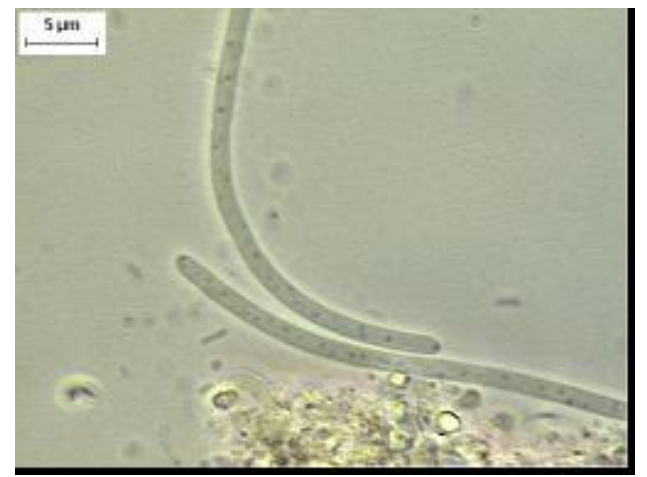

(b)

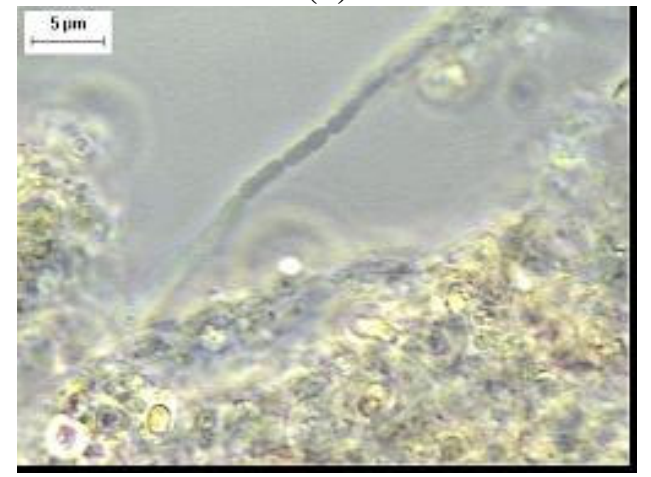

(d)

Figura 25. Fotomicrografia das principais morfologias encontradas nos grânulos do lodo no $342^{\circ}$ dia de operação do reator UASB: a) espirilo; b) filamentos; c) bacilos; d) bacilos em cadeia

Os resultados dos exames morfológicos realizados no $342^{\circ}$ dia de operação do reator UASB com aplicação de variação senoidal cíclica da vazão afluente em $40 \%$ indicaram a presença de espirilos, filamentos, bacilos e bacilos em cadeia.

A Figura 26 apresenta os principais tipos morfológicos observados nas amostras de lodo coletadas no $372^{\circ}$ dia de operação do reator UASB. 


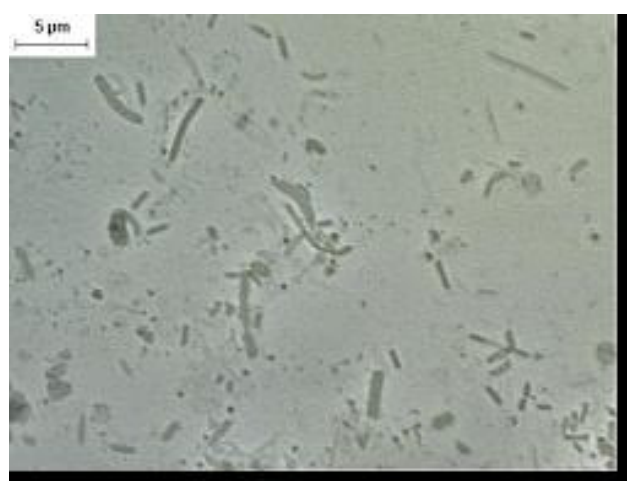

(a)

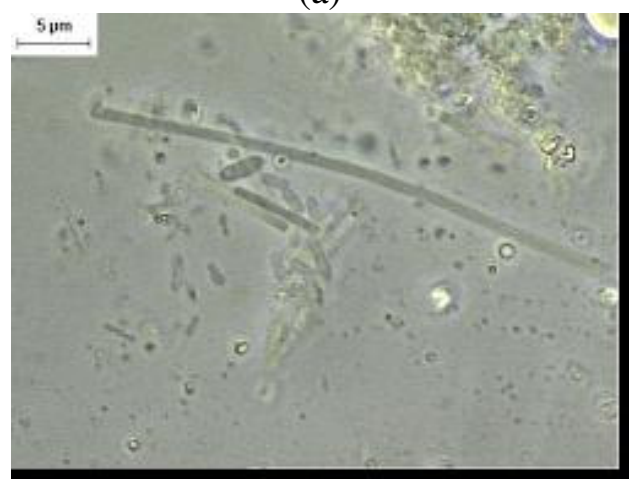

(c)

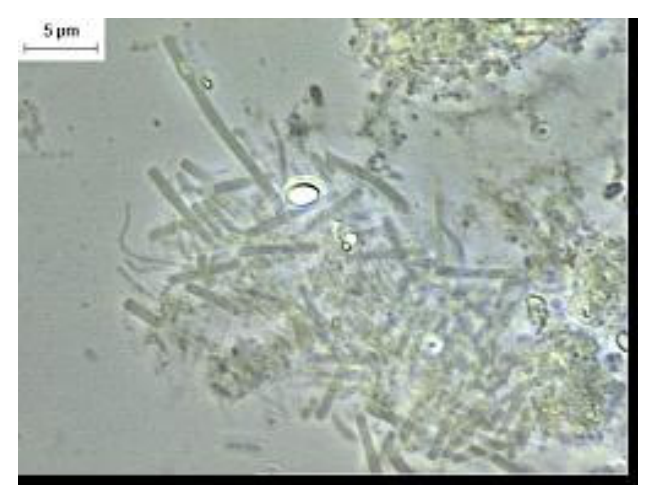

(b)

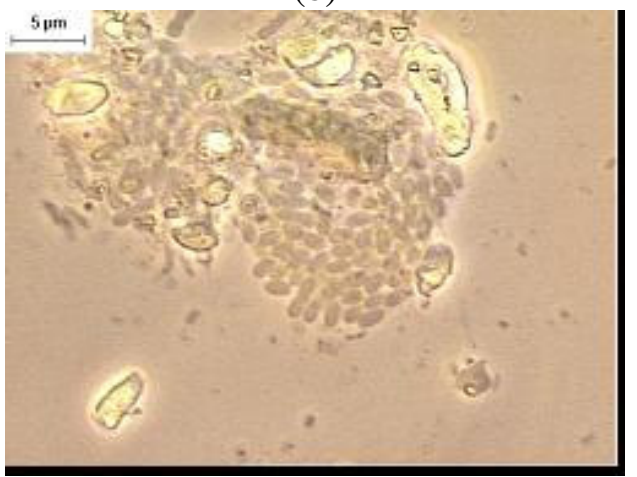

(d)

Figura 26. Fotomicrografia das principais morfologias encontradas nos grânulos do lodo no $372^{\circ}$ dia de operação do reator. a) bacilos; b) arquéias metanogênicas semelhantes a Metanosaeta sp.; c) filamentos, cocos, vibrios, bacilos; d) cocos e bacilos

As principais morfologias observadas na microscopia do $372^{\circ}$ dia de operação do reator com aplicação de variação senoidal cíclica da vazão afluente em $60 \%$ foram bacilos e bacilos em cadeia, arquéias metanogênicas semelhantes ao gênero Methanosaeta sp., cocos e vibrios.

\subsection{ENSAIOS DE ATIVIDADE METANOGÊNICA}

O objetivo dos ensaios de atividade metanogênica (AME) foi avaliar o comportamento das populações microbianas durante a operação do reator UASB submetido a: vazão média afluente constante e igual a 16,0 L.h ${ }^{-1}$ (TDH de $10 \mathrm{~h}$ ); variação senoidal cíclica em valores inferiores e superiores a $40 \%$ e $60 \%$ da vazão afluente. 
Conforme descrito previamente no item 4.1.7 - Ensaios de Atividade Metanogênica do capítulo Material e Métodos, as amostras do lodo para realização do ensaio de AME foram coletadas em três alturas (pontos de coleta 1, 2 e 3), após o reator ter alcançado o estado de equilíbrio dinâmico aparente nas três etapas de operação previamente citadas (Figura 27).

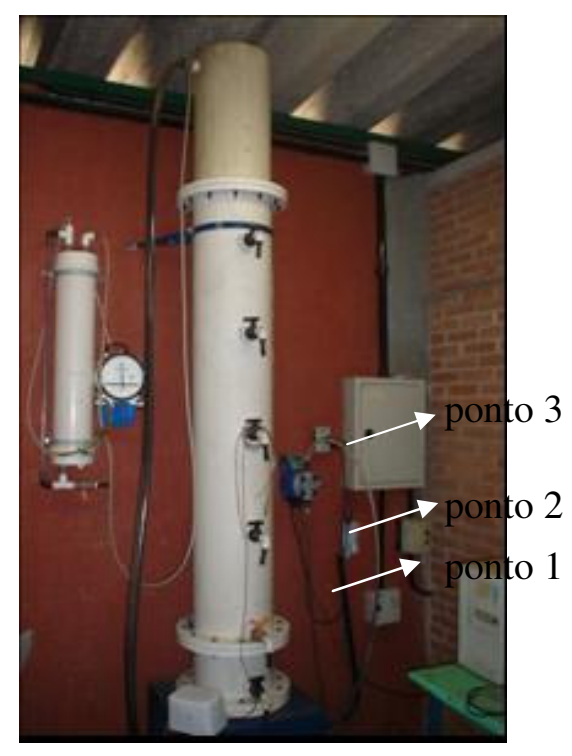

Figura 27. Pontos de coleta do reator UASB utilizados nos ensaios de AME

As análises de ST, STV e STF demonstraram concentrações mais elevadas nos pontos inferiores do reator (ponto $0-0 \mathrm{~cm}$, ponto $1-19 \mathrm{~cm}$ e ponto $2-56 \mathrm{~cm}$ de distância em relação a base do reator). As concentrações de STF obtidas ao longo da altura do reator corresponderam em média a $12 \%$ da concentração de ST. As concentrações de STV corresponderam em média a $88 \%$ da concentração ST.

Morfologias microbianas semelhantes foram observadas em todas as alturas do leito de lodo, independentemente da condição de operação aplicada no reator UASB. As morfologias observadas foram cocos, bacilos, bacilos fluorescentes, arquéias metanogênicas semelhantes ao gênero Methanosaeta sp. e arquéias metanogênicas semelhantes ao gênero Methanosarcina sp. (Figura 28). 


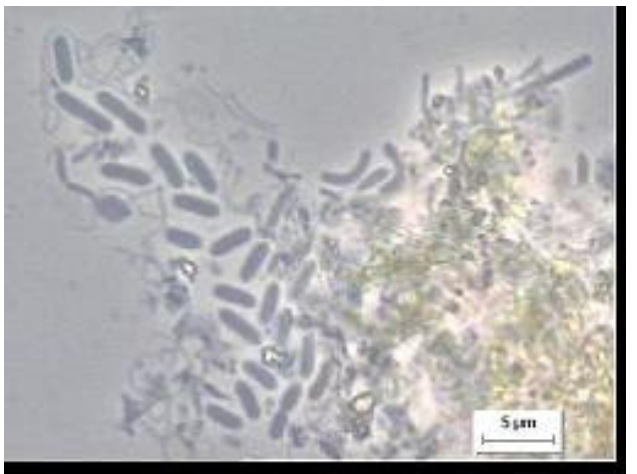

(a)

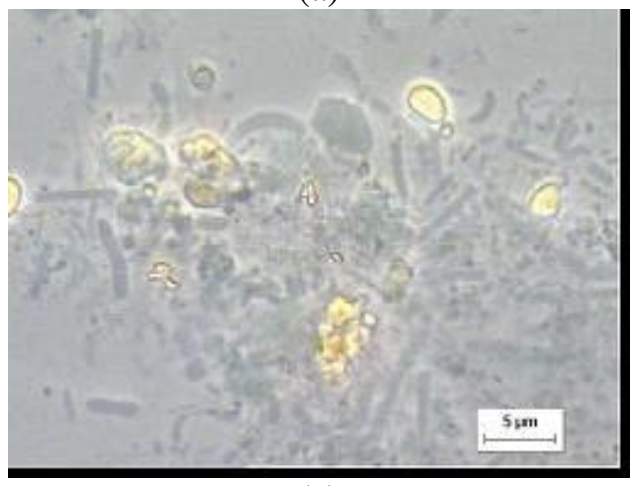

(c)

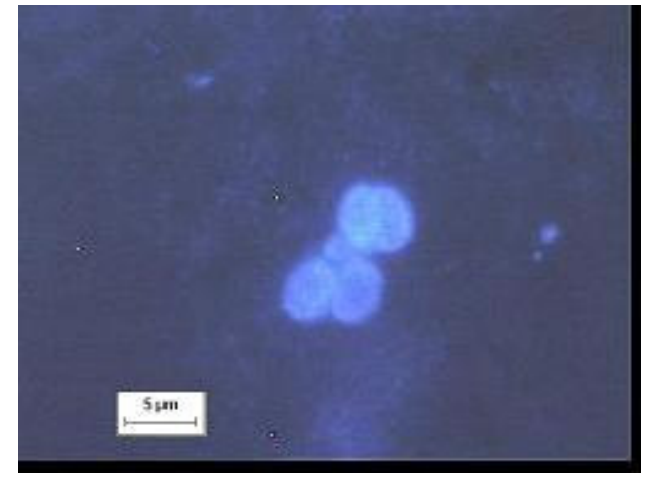

(b)

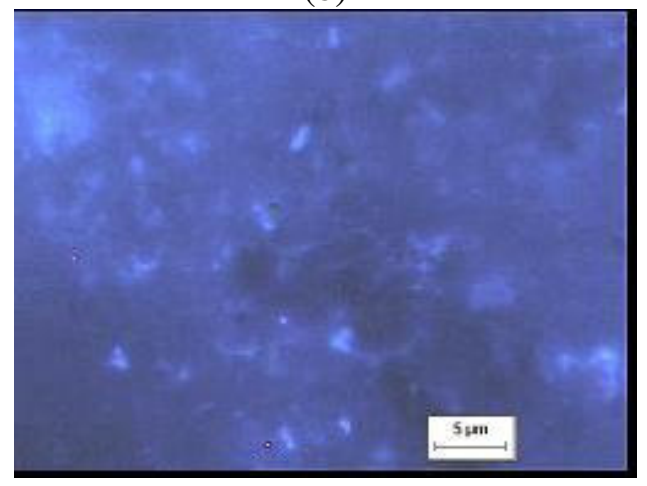

(d)

Figura 28. Fotomicrografia das morfologias predominantes na população microbiana presente em três alturas (Ualt1, 2 e 3) do reator UASB em três condições operacionais $\left(\mathbf{Q}_{\text {constante, }} \mathbf{Q}_{40 \%}\right.$ e $\left.\mathbf{Q}_{60 \%}\right)$ : a) bacilos, espirilos e vibrios; b) arquéias metanogênicas semelhantes ao gênero Methanosarcina sp.; c) bacilos, cocos, arquéias metanogênicas semelhantes ao gênero Methanosaeta sp.; d) bacilos fluorescentes. Aumento 1500x.

Os valores de AME encontrados em todas as condições foram mais elevados nos pontos 1 e 2 (variaram de 0,2072 a 0,5836 $\mathrm{mmolCH}_{4} \cdot \mathrm{g}^{-1} \mathrm{SV} \cdot \mathrm{h}^{-1}$ ) em relação ao ponto 3, que apresentou atividade microbiana apenas para as condições operacionais de vazão constante e com variação senoidal da vazão média afluente de $40 \%$. Os resultados indicaram que a degradação da matéria orgânica presente no substrato ocorreu no início do reator (pontos 1 e 2). Esse fato ficou ressaltado quando foram observados valores nulos para as atividades dos frascos-reatores de controle do ponto 3 nas três etapas de operação do reator, ou seja, a atividade microbiana ocorreu com utilização de matéria orgânica presente na própria amostra (Tabela 28). 
Os resultados obtidos para as atividades metanogênicas do ponto 1 foram $40 \%$ e 3,6\% mais elevados quando comparados àqueles obtidos para o ponto 2, com vazão afluente média constante e com aplicação de variação senoidal de 40\%, respectivamente. Entretanto, o ponto 2 apresentou atividade acentuadamente mais elevada (87\%) em relação ao ponto 1 na aplicação de variação senoidal de $60 \%$ na vazão afluente. Isso pode indicar um deslocamento da biomassa do ponto 1 para o ponto 2 , provavelmente devido ao aumento da velocidade ascensional que carreou os microrganismos do ponto 1 para o ponto 2 .

O comportamento da atividade microbiana no ponto 3 foi inverso aquele verificado nos pontos 1 e 2 . Os resultados obtidos para as atividades metanogênicas no ponto 3 diminuíram com a aplicação da vazão senoidal e com o aumento da amplitude da variação de $40 \%$ para $60 \%$ (Tabela 29).

Tabela 29. Atividade metanogênica aparente (AMA), atividade metanogênica específica (AME) e atividade no controle $\pm \mathrm{DV}\left(\mathrm{em} \mathrm{mmolCH}_{4} \cdot \mathrm{g}^{-1} \mathrm{SV} . \mathrm{d}^{-1}\right)$ encontradas para as populações microbianas presentes em três pontos do reator UASB operado em diferentes condições operacionais $\left(Q_{\text {constante }}, Q_{40 \%}\right.$ e $\left.\mathbf{Q}_{60 \%}\right)$

\begin{tabular}{|c|c|c|c|}
\hline Amostra & $\begin{array}{c}\text { AMA } \\
\left(\mathrm{mmol} \mathrm{CH}_{4} \mathrm{~g}^{-1} \mathrm{SV} \mathrm{d}^{-1}\right)\end{array}$ & $\begin{array}{c}\mathrm{AME} \\
\left(\mathrm{mmol} \mathrm{CH}_{4} \mathrm{~g}^{-1} \mathrm{SV} \mathrm{d}^{-1}\right)\end{array}$ & $\begin{array}{c}\text { Controle } \\
\left(\mathrm{mmol} \mathrm{CH}_{4} \mathrm{~g}^{-1} \mathrm{SV} \mathrm{d}^{-1}\right)\end{array}$ \\
\hline Ualt1 $Q_{\text {constante }}$ & $03428 \pm 0,0459$ & $0,2872 \pm 0,0459$ & $0,0556 \pm 0,0270$ \\
\hline Ualt2 $Q_{\text {constante }}$ & $0,3243 \pm 0,0666$ & $0,2072 \pm 0,0666$ & $0,1171 \pm 0,0344$ \\
\hline Ualt3 $Q_{\text {constante }}$ & $0,1554 \pm 0,0254$ & $0,1555 \pm 0,0254$ & 0 \\
\hline Ualt1 $\mathrm{Q}_{40 \%}$ & $0,3248 \pm 0,0191$ & $0,2967 \pm 0,0191$ & $0,0280 \pm 0,0000$ \\
\hline Ualt2 $\mathrm{Q}_{40 \%}$ & $0,3510 \pm 0,0169$ & $0,2847 \pm 0,0169$ & $0,0664 \pm 0,0193$ \\
\hline Ualt3 $\mathrm{Q}_{40 \%}$ & $0,0817 \pm 0,0226$ & $0,0817 \pm 0,0226$ & 0 \\
\hline Ualt1 $\mathrm{Q}_{60 \%}$ & $0,3668 \pm 0,0414$ & $0,3144 \pm 0,0414$ & $0,0524 \pm 0,0086$ \\
\hline Ualt2 $Q_{60 \%}$ & $0,6994 \pm 0,0728$ & $0,5836 \pm 0,0728$ & $0,1159 \pm 0,0940$ \\
\hline Ualt3 $\mathrm{Q}_{60 \%}$ & 0 & 0 & 0 \\
\hline
\end{tabular}

Os resultados da atividade metanogênica obtidos para o ponto 3 para as condições operacionais de vazão constante e igual a $16,0 \mathrm{~L} \mathrm{~h}^{-1}$ e com aplicação de variação senoidal da vazão afluente de $40 \%$ foram iguais a $0,1555 \mathrm{mmolCH}_{4} \cdot \mathrm{g}^{-1} \mathrm{SV} \cdot \mathrm{h}^{-1}$ e $0,0817 \mathrm{mmolCH}_{4} \cdot \mathrm{g}^{-1} \mathrm{SV} \cdot \mathrm{h}^{-1}$, respectivamente. Para a $3^{\mathrm{a}}$ etapa do experimento, com aplicação da variação senoidal da vazão afluente em $60 \%$, não foi observada atividade metanogênica dos microrganismos possivelmente devido ao arraste de sólidos causado pelo aumento da velocidade ascensional de operação do reator. 
A mesma tendência de comportamento encontrada nos pontos 1 e 2 foi verificado por Leitão (2004) em reator UASB operado com menor valor de TDH e submetido a choques hidráulicos e orgânicos. Por outro lado, o autor observou pequeno aumento na atividade metanogênica quando a DQO afluente diminuiu de 816 mg. $\mathrm{L}^{-1} \quad\left(0,18\right.$ kgDQO. $\left.\mathrm{kg}^{-1} \mathrm{SV} \quad \mathrm{d}^{-1}\right)$ para 195 e $92 \quad \mathrm{mg} \cdot \mathrm{L}^{-1} \quad(0,23$ e $\left.0,22 \mathrm{kgDQO} \cdot \mathrm{kg}^{-1} \mathrm{SV} \cdot \mathrm{d}^{-1}\right)$, respectivamente.

Aparentemente as variações cíclicas senoidais não interferiram na atividade microbiana como um todo, uma vez que o desempenho do reator apresentou resultados semelhantes para remoção de matéria orgânica em termos de DQO bruta e filtrada (Tabela 30). Foi possível verificar decréscimo da eficiência do reator na remoção de matéria orgânica com o aumento da amplitude da variação cíclica senoidal da vazão afluente, provavelmente devido ao arraste de sólidos quando maiores velocidades ascensionais foram aplicadas.

Tabela 30. Eficiências alcançadas pelo reator UASB tratando substrato nas três condições operacionais: vazão média afluente constante $\left(Q_{\text {constante }}\right)$, variação senoidal da vazão média afluente em $40 \%\left(Q_{40 \%}\right)$ e em $60 \%\left(Q_{60 \%}\right)$

\begin{tabular}{ccc}
\hline Vazão & $\begin{array}{c}\text { Eficiência de remoção de DQO } \\
(\boldsymbol{\%})\end{array}$ & $\begin{array}{c}\text { Eficiência de remoção de DQO } \\
(\boldsymbol{\%})\end{array}$ \\
\hline $\mathrm{Q}_{\text {constiltrada }}$ & 73 \\
$\mathrm{Q}_{40 \%}$ & 65 & 60 \\
$\mathrm{Q}_{60 \%}$ & 55 & 58 \\
\hline
\end{tabular}

\subsection{ENSAIOS DA COMUNIDADE MICROBIANA}

A análise da estrutura da comunidade microbiana foi realizada para três diferentes condições operacionais, sendo reator UASB submetido à vazão afluente constante e a variações senoidais cíclicas de $40 \%$ e $60 \%$.

As amostras para realização dos ensaios foram coletadas dos mesmos pontos utilizados nos ensaios de atividade metanogênica.

A Figura 29 apresenta o perfil de bandas do DGGE para o domínio Archaea. 


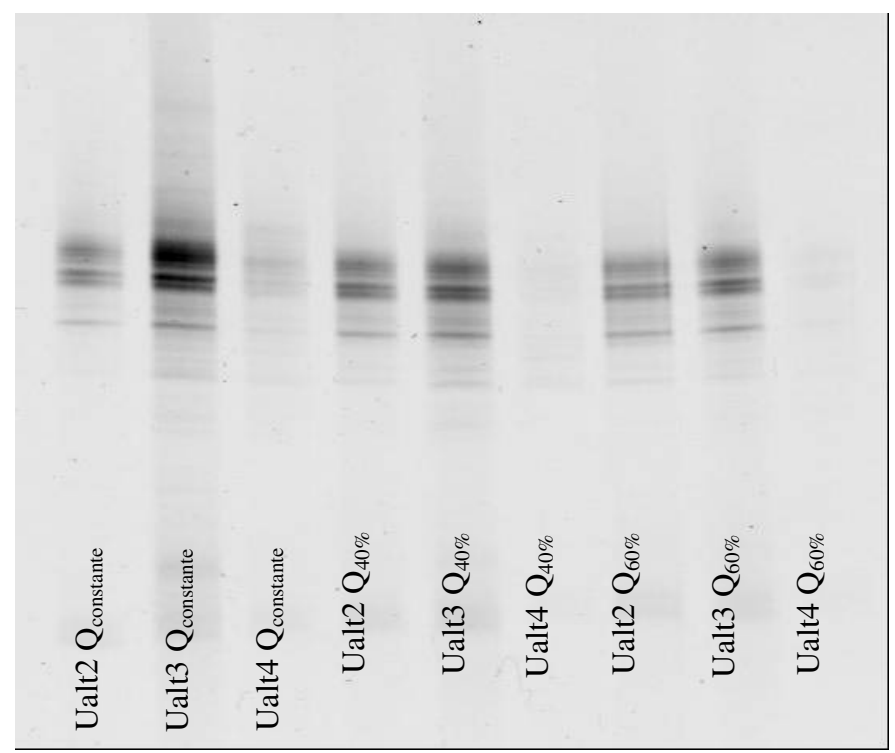

Figura 29. Perfil de bandas no DGGE com primers para o domínio Archaea $(1100$ FGC e $1400 \mathrm{R})$ das populações microbianas presentes em três pontos do reator em três condições operacionais $\left(Q_{\text {constante, }} \mathbf{Q}_{40 \%}\right.$ e $\left.\mathbf{Q}_{60 \%}\right)$. Os pontos 2,3 e 4 correspondem aos pontos de coleta 1,2 e 3 .

A Figura 30 apresenta o perfil de bandas do DGGE para o domínio Bacteria.

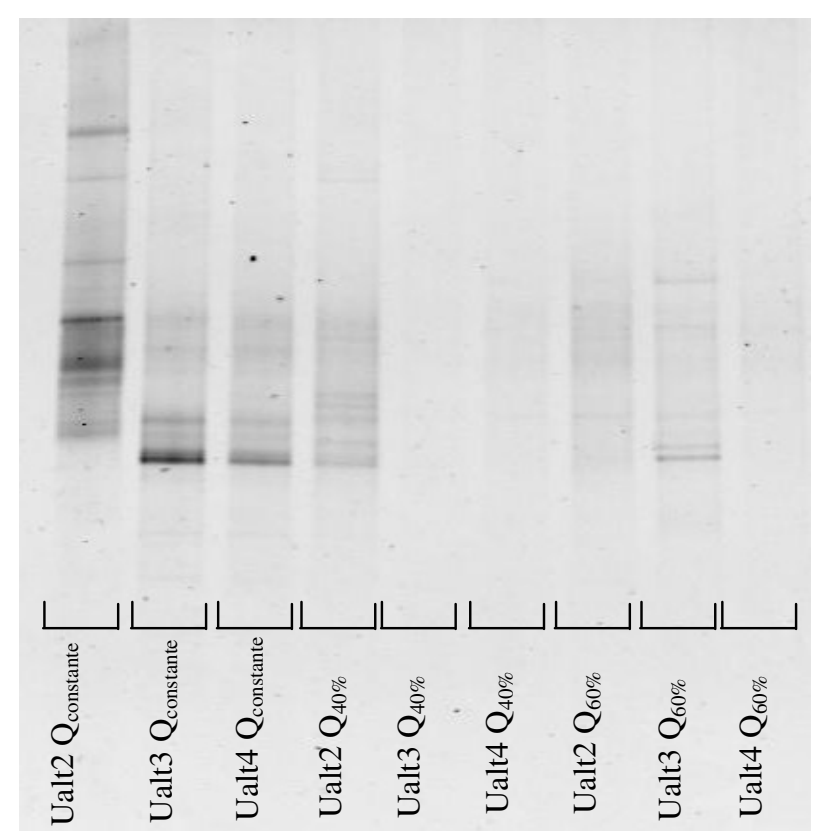

Figura 30. Perfil de bandas no DGGE com primers para o domínio Bacteria (968 FGC e 1392 R) das populações microbianas presentes em três pontos do reator UASB em três condições operacionais $\left(Q_{\text {constante, }} \mathbf{Q}_{40 \%}\right.$ e $\left.\mathbf{Q}_{60 \%}\right)$. Os pontos 2,3 e 4 correspondem aos pontos de coleta 1,2 e 3 . 
A análise do DGGE mostrou que não ocorreu variação na estrutura da comunidade de arquéias (Figura 29) entre os três pontos estudados nas três condições operacionais, com exceção do ponto 3 que não apresentou bandas no gel para as amostras das vazões com variação senoidal da vazão afluente de $40 \%$ e de $60 \%$.

Com variação senoidal da vazão afluente em valores inferiores e superiores a $40 \%$, a população microbiana nesse ponto diminuiu em relação àquela verificada na condição operacional com vazão constante de tal forma que a extração e a amplificação por PCR do DNA não permitiram concentração suficiente para detecção no DGGE.

Por outro lado, a não verificação de bandas no ponto 3 para variação senoidal da vazão afluente de $60 \%$, indicou a ausência de microrganismos para esse ponto e para essa condição operacional, como já havia sido demonstrado pelo resultado nulo da AME.

O perfil de bandas do DGGE com primers para o domínio Bacteria (Figura 30) mostrou por sua vez, que houve diferença entre as populações encontradas no ponto 1 em relação àquelas observadas nos pontos 2 e 3. Além disso, a aplicação das vazões senoidais cíclicas da vazão média afluente causou a diminuição da intensidade das bandas e o desaparecimento das mesmas em algumas situações (Ualt3 $\mathrm{Q}_{40 \%}$, Ualt4 $\mathrm{Q}_{40 \%}$ e Ualt4 $\mathrm{Q}_{60 \%}$ ). Portanto os resultados indicaram que o Domínio Bacteria foi mais sensível às variações senoidais cíclicas de vazão em relação ao Domínio Archaea.

\subsection{ENSAIOS HIDRODINÂMICOS}

Nesse item são apresentados os resultados obtidos nos ensaios hidrodinâmicos do reator UASB, quando operado com vazão média afluente constante e igual a 16,0 L.h ${ }^{-1}$ e quando submetido a variações senoidais cíclicas da vazão média afluente em $40 \%$ e $60 \%$.

Conforme descrito anteriormente no item 4.1.8 - Ensaios Hidrodinâmicos do capítulo Material e Métodos, ensaios de estímulo-resposta tipo pulso foram realizados com traçador Eosina $\mathrm{Y}$ na caracterização hidrodinâmica do reator. As 
injeções de volume de $20 \mathrm{~mL}$ de Eosina Y com concentrações variáveis para cada etapa de operação foram feitas na mangueira afluente ao reator UASB em tempo de aproximadamente $50 \mathrm{~s}$.

A Figura 31 apresenta as curvas de variação das concentrações do traçador eosina $\mathrm{Y}$ ao longo do tempo nas amostras do efluente do reator.

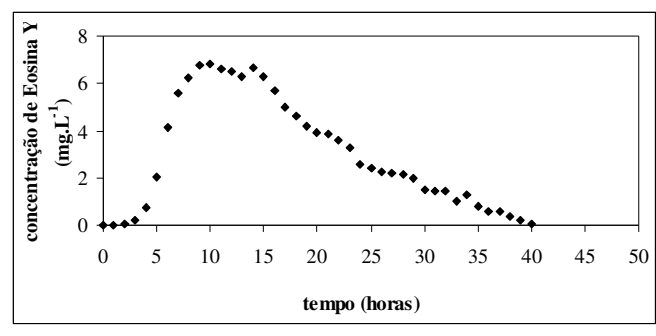

(a)

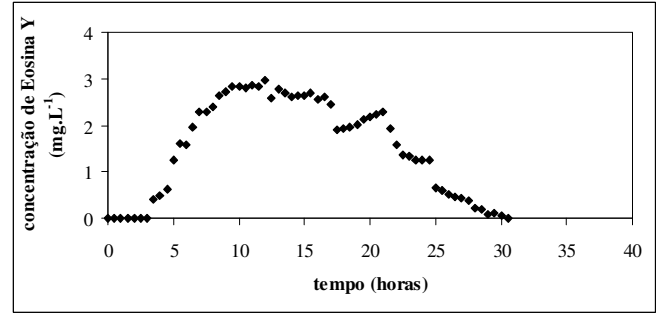

(c)

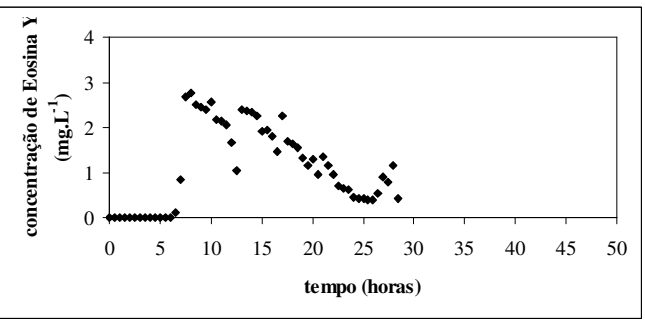

(e)

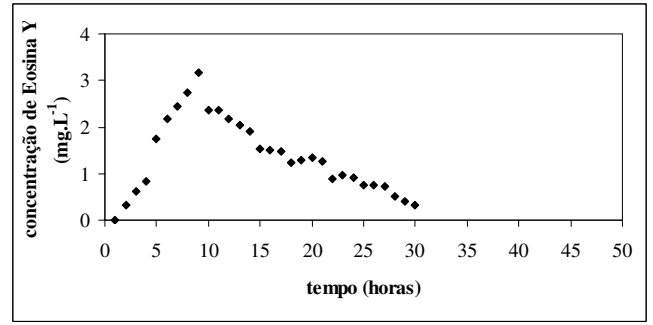

(b)

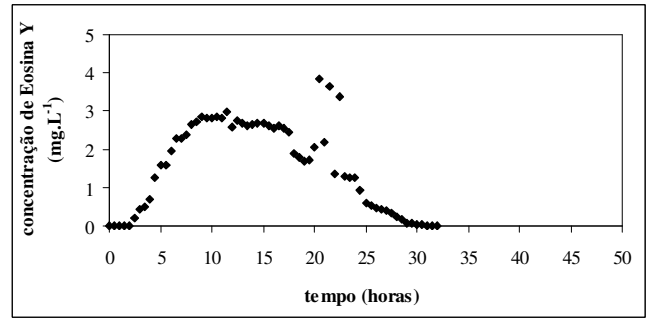

(d)

Figura 31. Curvas de variação da concentração de eosina $Y$ ao longo do tempo nas amostras do efluente do reator para os ensaios de estímulo-resposta: vazão afluente constante - a) ensaio 1; b) ensaio 2; variação de $40 \%$ da vazão afluente c) ensaio 3; d) ensaio 4; variação de $60 \%$ da vazão afluente - e) ensaio 5

$\mathrm{O}$ lento decaimento observado nas concentrações de eosina $\mathrm{Y}$ ao longo do tempo pode indicar o fenômeno de "cauda", tanto para os ensaios realizados com vazão média afluente constante de $16,0 \mathrm{~L} \cdot \mathrm{h}^{-1}$ e tempo de detenção hidráulica de aproximadamente $10 \mathrm{~h}$ (Figura 31.a; Figura 31.b), quanto para os experimentos realizados com variação senoidal cíclica da vazão afluente de $40 \%$ e de $60 \%$ (Figura 31.c, Figura 31.d e Figura 31.e). O efeito da cauda provavelmente ocorreu devido aos fenômenos de difusão em zonas mortas do reator, adsorção do traçador na biomassa 
do reator ou curto circuito hidráulico (LEVENSPIEL, 1999). Outros estudos também observaram esse efeito (JIMÉNEZ et al., 1988; DE NARDI et al.,1999; LIMA, 2001).

Jiménez et al. (1988) observaram o fenômeno de cauda devido à difusão da eosina $\mathrm{Y}$ e de outros traçadores que distorcem o formato das curvas de resposta e levam ao erro do ajuste dos modelos matemáticos e da interpretação do comportamento hidrodinâmico de reatores.

De Nardi et al. (1999) observaram o efeito da cauda na determinação do comportamento hidrodinâmico do reator anaeróbio horizontal de leito fixo (RAHLF) com lodo imobilizado em meio suporte de cerâmica. Os ensaios de estímulo-resposta tipo pulso foram realizados com os traçadores dextrano azul, bromocresol verde e eosina Y em meio abiótico e o efeito de cauda observado pode ter ocorrido devido ao fenômeno de difusão do traçador no meio suporte utilizado.

Lima (2001) avaliou a hidrodinâmica de reator anaeróbio horizontal com leito fixo (RAHLF) utilizando água e esgoto em diversos estágios de operação e vazão volumétrica, com diferentes traçadores, dentre eles a eosina Y. O autor constatou visualmente a adsorção desse traçador na espuma com a abertura do reator após os ensaios. O traçador permaneceu retido na espuma após uma série de lavagens e retirada do volume estagnado em uma matriz. Apesar do fenômeno observado, o autor constatou que o traçador foi adequado para o monitoramento dos desvios do escoamento e do comprometimento do volume útil ao longo dos estágios de operação.

Mesmo após a centrifugação das amostras do efluente para os ensaios de estímulo-resposta 3, 4 e 5, foi possível verificar algumas variações nas leituras de absorbância devido à presença de sólidos nessas amostras (Figura 31.c; Figura 31.d e Figura 31.e). Os pontos isolados das curvas de variação da concentração de eosina $Y$ ao longo do tempo foram desconsiderados na análise matemática por apresentarem concentração anormal de traçador.

Os valores obtidos para recuperação da massa do traçador injetada no reator resultaram em: $85 \%$ e $86 \%$ para os ensaios 1 e 2, respectivamente; $88 \%$ e $90 \%$ para os ensaios 3 e 4 , respectivamente e $90 \%$ para o ensaio 5 . 
Jiménez et al. (1988) obtiveram recuperação de traçador nas amostras do efluente variando de 41 a $51 \%$ em ensaios com eosina Y na presença de biomassa; Brito e Melo (1997) alcançaram recuperação de 95\% do cloreto de lítio usado em estudo hidrodinâmico de reator UASB com biomassa anaeróbia granular; Lima (2001) obteve porcentagem de recuperação de $90 \%$ da massa injetada ao avaliar a hidrodinâmica do reator RAHLF tratando esgoto sanitário; Passig (2005) obteve recuperação de traçador variando de $42 \%$ a $89 \%$ na operação de reator UASB em escala real $\left(18,8 \mathrm{~m}^{3}\right)$ tratando esgoto sanitário.

A Tabela 31 apresenta os resultados obtidos com o ajuste das curvas de distribuição do tempo de residência pelos modelos matemáticos teóricos, de acordo com Levenspiel (1999).

Tabela 31. Parâmetros obtidos com o ajuste dos dados experimentais para reator UASB

\begin{tabular}{cccccc}
\hline \multirow{2}{*}{ Etapas } & Ensaios & $\theta \mathrm{h}$ & N-CSTR & Pequena Dispersão & $\begin{array}{c}\text { Grande } \\
\text { Dispersão }\end{array}$ \\
\hline & & $(\mathrm{h})$ & & $(\mathrm{PD})$ & $(\mathrm{GD})$ \\
\hline 1 & 1 & 16 & 5 & 0.112 & 0.075 \\
& 2 & 14 & 4 & 0.121 & 0.079 \\
2 & 3 & 15 & 8 & 0.064 & 0.075 \\
& 4 & 15 & 7 & 0.072 & 0.075 \\
3 & 5 & 15 & 11 & 0.045 & 0.075 \\
\hline
\end{tabular}

Observa-se em todos os ensaios que o tempo de detenção hidráulico real obtido por meio da curva DTR variou entre $14 \mathrm{~h}$ e $16 \mathrm{~h}$. Os valores experimentais obtidos foram superiores ao TDH teórico por apresentarem diferenças significativas de $40 \%$ e de $60 \%$ nos ensaios 1 e 2 , respectivamente e de $50 \%$ nos ensaios 3 , 4 e 5 em relação ao tempo de detenção hidráulico teórico de aproximadamente $10 \mathrm{~h}$. Esses resultados demonstraram atraso na resposta do traçador, o que pode indicar existência de zonas mortas no interior do reator ou adsorção do traçador na biomassa. O traçador teria se difundido nestas zonas mortas, sendo liberado aos poucos, o que provoca atraso em sua resposta na saída do reator e gera o fenômeno de cauda longa, como foi observado nas curvas experimentais.

Se observarmos os dados da Tabela 31, nota-se que os valores de tempo de detenção hidráulica (TDH= $\theta \mathrm{h})$ não apresentaram diferenças significativas nos ensaios realizados. Porém na etapa 1 (sem variação de vazão), o modelo teórico de 
N-CSTR em série obteve valores iguais a 5 e 4 reatores e o modelo de pequena dispersão valores iguais a 0,112 e 0,121. Portanto pode-se concluir que os valores encontrados estão muito próximos aos reportados por Passig (2005), que constatou que o reator UASB equivale a 5 reatores de mistura perfeita em série e obteve valor de 0,11 para o modelo de pequena dispersão.

Ainda na Tabela 31, nas etapas 2 e 3 observa-se aumento do número de NCSTR em série e diminuição do valor referente ao modelo de pequena dispersão, provavelmente devido ao aumento da amplitude da variação da vazão afluente. $\mathrm{O}$ aumento da amplitude de variação de vazão média afluente ocasionou aumento do NCSTR para 11 reatores de mistura perfeita em série e diminuição do valor de pequena dispersão para valor igual a 0,045. Com isso o comportamento hidrodinâmico do reator se aproxima do reator de fluxo pistonado. Cabe salientar que os valores do modelo de grande dispersão não sofreram alteração em função do aumento da amplitude de variação da vazão afluente ao reator.

A Tabela 32 apresenta os resultados de coeficientes de correlação obtidos para os modelos matemáticos teóricos.

Tabela 32. Coeficientes de correlação obtidos com o ajuste dos resultados experimentais pelos modelos teóricos

\begin{tabular}{ccccc}
\hline \multicolumn{5}{c}{ Coeficiente de correlação (r) } \\
\hline Etapas & Ensaios & Pequena Dispersão & Grande Dispersão & N-CSTR em série \\
\hline 1 & 1 & 0.809 & 0.809 & 0.663 \\
& 2 & 0.890 & 0.867 & 0.720 \\
2 & 3 & 0.890 & 0.772 & 0.742 \\
& 4 & 0.795 & 0.779 & 0.714 \\
3 & 5 & 0.771 & 0.704 & 0.705 \\
\hline
\end{tabular}

Na Tabela 32, pode-se observar que o modelo matemático de pequena dispersão apresentou os melhores ajustes dos dados experimentais para os ensaios com vazão média afluente constante e com variação senoidal cíclica da vazão afluente.

Os valores do tempo de detenção hidráulica $(\theta h)$ e do parâmetro $\mathrm{N}$ não apresentaram diferenças significativas, o que indicou grau de mistura semelhante para os ensaios realizados (Tabela 32). 
As curvas de concentração de traçador ao longo do tempo, $\mathrm{C}(\mathrm{t})$, foram normalizadas de acordo com Levenspiel (1999), resultando em curvas de distribuição do tempo de detenção hidráulica $\left(\mathrm{E}_{\theta} \times \quad \theta\right)$. Essas curvas, em função do tempo adimensional, foram então ajustadas pelos modelos teóricos uniparamétricos de dispersão de pequena (PD) e de grande intensidade (GD) e de tanques em série (NCSTR).

As curvas experimentais de distribuição do tempo de residência (DTR) obtidas com o ajuste de modelos matemáticos são apresentadas na Figura 32.

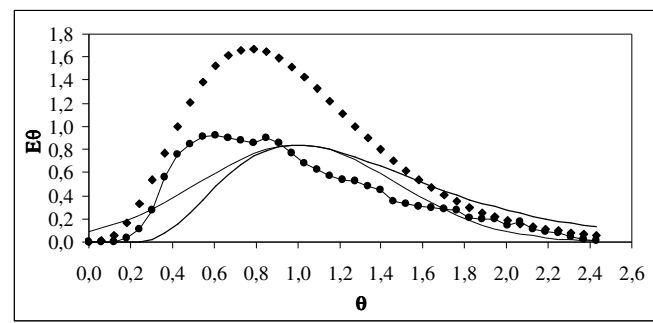

(a)

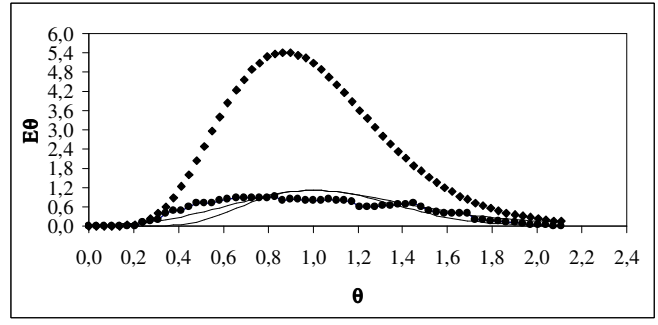

(c)

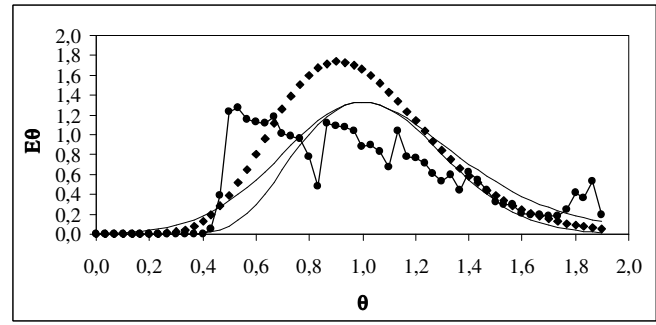

(e)

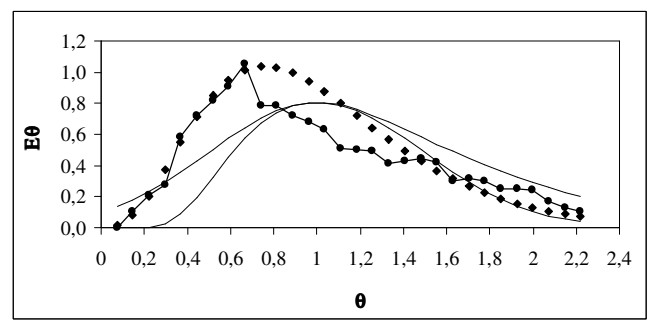

(b)

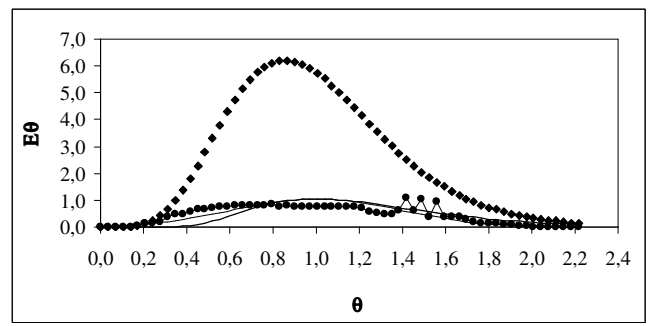

(d)

Figura 32. Curvas de DTR obtidas experimentalmente com uso de eosina $Y$ em diferentes condições operacionais do reator UASB: vazão afluente constante - a) ensaio 1; b) ensaio 2; variação de $40 \%$ da vazão afluente - c) ensaio 3; d) ensaio 4; variação de $60 \%$ da vazão afluente - e) ensaio 5. •dados experimentais; -----pequena dispersão; $\bullet$ N-CSTR em série; — grande dispersão

Observa-se que os modelos de pequena dispersão (PD) e de grande dispersão (GD) apresentaram melhor ajuste aos dados experimentais, apesar de inicialmente os 
ensaios não respeitarem suas premissas $(\mathrm{D} / \mathrm{uL}<0,01$ e dispersão idêntica dentro e fora do volume de controle). Entretanto, isto não significa que o ajuste tenha sido satisfatório, porque, mesmo neste modelo, foi grande a dispersão em relação aos valores experimentais.

Como o modelo N-CSTR previu a ocorrência de uma concentração máxima de traçador, a qual não ocorreu, seu ajuste tornou-se comprometido.

Nos perfis experimentais, foi detectada atenuação do pico devido ao retardo da passagem do traçador da porção posterior ao pico (efeito de cauda).

Com os levantamentos hidrodinâmicos foi possível concluir que o reator UASB apresentou comportamento próximo ao de reator de mistura completa, comparado à aproximadamente 4 ou 5 N-CSTR em série, para o ensaio sem variação de vazão afluente. Com o aumento da amplitude da variação da vazão afluente do reator constatou-se que o reator se aproximou do reator de fluxo pistonado.

Apesar da aplicação das variações senoidais cíclicas de $40 \%$ e 60\%, os parâmetros tempo de detenção hidráulica e grau de mistura do reator não apresentaram diferenças significativas quando comparados àqueles parâmetros obtidos para vazão média afluente constante.

Ao comparar o tempo de detenção hidráulico teórico com o calculado pelas curvas de DTR obtidas experimentalmente, verificou-se atraso de aproximadamente $50 \%$ da resposta do traçador que poderia indicar existência de zonas mortas hidrodinâmicas no interior do reator. $\mathrm{O}$ fenômeno de cauda observado nas curvas obtidas resultou da difusão do traçador nessas zonas mortas e de sua lenta liberação.

\subsection{CALIBRAÇÃO DO MODELO ADM1}

Os dados experimentais obtidos com a operação do reator UASB foram analisados e aplicados como dados de entrada para o ADM1. Primeiramente foi realizada a conversão das unidades de alguns parâmetros para adequar as unidades requisitadas pelo ADM1, como por exemplo em molC.gDQO ${ }^{-1}$, molN.gDQO ${ }^{-1}$, kgDQO. $\mathrm{m}^{-3}, \mathrm{KmolC} . \mathrm{m}^{-3}, \mathrm{KmolN} . \mathrm{m}^{-3}$. A conversão foi necessária para que os valores dos parâmetros observados pudessem ser aplicados como estimativa inicial para o conjunto de parâmetros do modelo ADM1. 
O modelo ADM1 foi implementado como um conjunto de equações diferenciais ordinárias (ODE) que foram resolvidas numericamente pela função solver ODE $15 \mathrm{~s}$ da ferramenta computacional Matlab/Simulink. Os resultados das simulações foram comparados com os dados medidos experimentalmente para possibilitar a calibração do modelo (Figura 33).

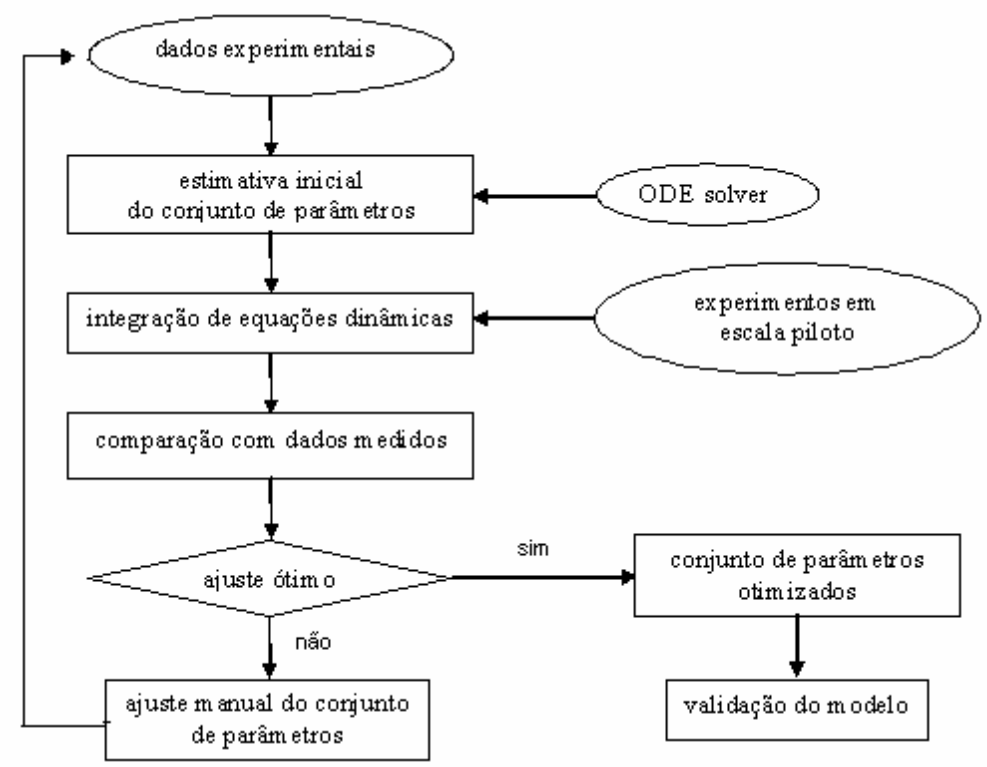

Figura 33. Procedimento de estimativa para identificação de parâmetros

Apesar das diversas tentativas de calibração do modelo, não foi possível observar similaridade entre os resultados simulados e os observados do efluente na maioria dos parâmetros de monitoramento, tais como DQO bruta, pH, concentração de ácidos voláteis, concentração de sólidos suspensos voláteis e alcalinidade a bicarbonato. Assim, foi necessário ajustar manualmente o conjunto de valores de parâmetros e efetuar novas simulações do ADM1 (Figura 33).

Os valores iniciais de alguns parâmetros foram obtidos a partir dos resultados experimentais de operação do reator UASB e de dados reportados por Batstone et al. (2002a,b). Os coeficientes estequiométricos, parâmetros físico-químicos (coeficientes de equilíbrio e constantes) e os parâmetros cinéticos (considerados constantes) foram obtidos de Batstone et al. (2002a,b).

A Tabela 33 apresenta os parâmetros estequiométricos calculados de acordo com os resultados experimentais e os sugeridos por Batstone et al. (2002a,b). 
Tabela 33. Parâmetros estequiométricos (calculados e sugeridos)

\begin{tabular}{|c|c|c|c|c|}
\hline \multirow[t]{2}{*}{ descrição } & \multirow[t]{2}{*}{ simbologia } & \multicolumn{2}{|c|}{ parâmetros } & \multirow[t]{2}{*}{ descrição } \\
\hline & & calculado & sugerido & \\
\hline fsI, $\mathrm{xc}$ & f_sI_xc & 0,15 & 0,1 & Inertes solúveis de compostos \\
\hline fxI,xc & f_xI_xc & 0,06 & 0,25 & Inertes particulados de compostos \\
\hline $\mathrm{fch}, \mathrm{xc}$ & f_ch_xc & 0,20 & 0,2 & Carboidratos de compostos \\
\hline $\mathrm{fpr}, \mathrm{xc}$ & f_pr_xc & 0,25 & 0,2 & Proteínas de compostos \\
\hline fli,xc & f_li_xc & 0,34 & 0,25 & Lipídeos de compostos \\
\hline ffa,li & f_fa_li & 0,97 & $0,91-0,98$ & Ácidos graxos de lipídeos \\
\hline $\mathrm{N}_{\mathrm{xc}}$ & N_xc & - & 0,002 & Nitrogênio de compostos \\
\hline $\mathrm{N}_{\mathrm{I}}$ & N_I & - & 0,002 & Nitrogênio de inertes \\
\hline fac,su & f_AC_SU & 0,35 & 0,41 & Acetato de monossacarídeos \\
\hline fpro,su & f_PRO_SU & 0,34 & 0,27 & Propionato de monossacarídeos \\
\hline fbut,su & f_BU_SU & 0,15 & 0,13 & Butirato de monossacarídeos \\
\hline fh2,su & f_H2_SU & 0,16 & 0,19 & Hidrogênio de monossacarídeos \\
\hline fac,aa & f_AC_AA & 0,40 & 0,53 & Acetato de aminoácidos \\
\hline fpro,aa & f_PRO_AA & 0,06 & 0,07 & Propionato de aminoácidos \\
\hline fbut,aa & f_BU_AA & 0,18 & 0,19 & Butirato de aminoácidos \\
\hline fva,aa & f_VA_AA & 0,18 & 0,19 & Valerato de aminoácidos \\
\hline fh2, aa & f_H2_AA & 0,01 & 0,01 & Hidrogênio de aminoácidos \\
\hline fIN, aa & f_IN_AA & 0,01 & 0,011 & Nitrogênio inorgânico de aminoácidos \\
\hline $\mathrm{Naa}$ & N_aa & - & 0,007 & Nitrogênio em aminoácidos e proteínas \\
\hline $\mathrm{N} 1$,su (acetato) & - & 0,39 & - & Acetato via monossacarídeos \\
\hline $\mathrm{N} 2$,su (acetato/propionato) & - & 0,43 & - & Acetato + Propionato via monossacarídeos \\
\hline $\mathrm{N} 3$, su (butirato) & - & 0,18 & - & Butirato via monossacarídeos \\
\hline
\end{tabular}

Fonte: adaptado de Batstone et al. (2002a,b)

Os termos de balanço de massa para o carbono e nitrogênio foram aplicados nas matrizes de equações de taxa (Tabela 11 e Tabela 12) com o objetivo de realizar o balanço de massa desses componentes. Assim, os conteúdos de carbono e nitrogênio foram recalculados até que se obtivesse o fechamento dos balanços de massa desses parâmetros, ou seja, valor igual a 0 para o somatório dos componentes (i) em cada etapa do processo (j).

Os conteúdos de carbono e de nitrogênio das variáveis do sistema foram recalculados após a aplicação dos termos de balanço nas matrizes de equações de taxa com o objetivo de fechar o balanço de carbono e nitrogênio (Tabela 34).

A Tabela 34 apresenta a estimativa dos conteúdos de carbono e nitrogênio dos componentes presentes no substrato avaliado experimentalmente. 
Tabela 34. Estimativa dos conteúdos de carbono e de nitrogênio presentes na composição do substrato

\begin{tabular}{|c|c|c|c|c|c|}
\hline descrição & simbologia & conteúdo de $\mathrm{C}$ & conteúdo de $\mathbf{N}$ & unidade & descrição \\
\hline$*$ Cbac & C-BAC & $3,1250 \mathrm{E}-02$ & - & $\mathrm{mol} \mathrm{C.gDQO}^{-1}$ & Carbono na biomassa \\
\hline $\mathrm{Cxc}$ & C_C & por ajuste & - & $\mathrm{mol} \mathrm{C.gDQO}^{-1}$ & Carbono no composto \\
\hline Cch & C_CH & $3,1250 \mathrm{E}-02$ & - & $\mathrm{mol} \mathrm{C.gDQO}^{-1}$ & Carbono no carboidrato \\
\hline $\mathrm{Cpr}$ & C_PR & $2,9940 \mathrm{E}-02$ & - & $\mathrm{mol} \mathrm{C.gDQO}^{-1}$ & Carbono na proteína \\
\hline Cli & C_LI & 2,1983E-02 & - & $\mathrm{mol} \mathrm{C.gDQO}^{-1}$ & Carbono no lipídeo \\
\hline Csi & C_SI & por ajuste & - & 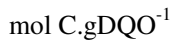 & Carbono no inerte solúvel \\
\hline Cxi & C_XI & por ajuste & - & $\mathrm{mol} \mathrm{C.gDQO}^{-1}$ & Carbono no inerte particulado \\
\hline Csu & C_SU & $3,1250 \mathrm{E}-02$ & - & $\mathrm{mol} \mathrm{C.gDQO}^{-1}$ & Carbono no monossacarídeo \\
\hline $\mathrm{Caa}$ & C_AA & 2,9940E-02 & - & $\mathrm{mol} \mathrm{C.gDQO}^{-1}$ & Carbono no aminoácido \\
\hline Clcfa & C_FA & $2,1739 \mathrm{E}-02$ & - & $\mathrm{mol} \mathrm{C.gDQO}^{-1}$ & Carbono no ácido graxo \\
\hline Cva & C_VA & $2,4038 \mathrm{E}-02$ & - & $\mathrm{mol} \mathrm{C.gDQO}^{-1}$ & Carbono no valerato \\
\hline $\mathrm{Cbu}$ & C_BU & $2,5000 \mathrm{E}-02$ & - & 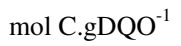 & Carbono no butirato \\
\hline Cpro & C_PRO & $2,6786 \mathrm{E}-02$ & - & $\mathrm{mol} \mathrm{C.gDQO}^{-1}$ & Carbono no propionato \\
\hline $\mathrm{Cac}$ & C_AC & $3,1250 \mathrm{E}-02$ & - & mol C.gDQO ${ }^{-1}$ & Carbono no acetato \\
\hline $\mathrm{Ch} 2$ & C_H2 & - & - & $\mathrm{mol} \mathrm{C.gDQO}^{-1}$ & Carbono no hidrogênio \\
\hline Cch4 & C_CH4 & $1,5625 \mathrm{E}-02$ & - & 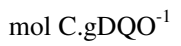 & Carbono no metano \\
\hline Cin & C_IN & - & $1,0000 \mathrm{E}+00$ & 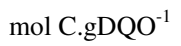 & Carbono no nitrogênio inorgânico \\
\hline $\mathrm{Cic}$ & C_IC & $1,0000 \mathrm{E}+00$ & - & 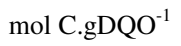 & Carbono no carbono inorgânico \\
\hline Naa & N_AA & - & $7,0000 \mathrm{E}-03$ & 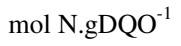 & Nitrogênio no aminoácidos \\
\hline$* \mathrm{Nbac}$ & N_BAC & - & $6,2500 \mathrm{E}-03$ & 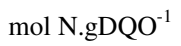 & Nitrogênio na biomassa \\
\hline Nsi & N_SI & - & $2,0000 \mathrm{E}-03$ & 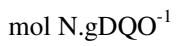 & Nitrogênio no inerte solúvel \\
\hline $\mathrm{Nxc}$ & N_XC & - & $2,0000 \mathrm{E}-03$ & mol N.gDQO ${ }^{-1}$ & Nitrogênio no composto \\
\hline Nxi & N_XI & - & $2,0000 \mathrm{E}-03$ & mol N.gDQO ${ }^{-1}$ & Nitrogênio no inerte particulado \\
\hline
\end{tabular}

Fonte: adaptado de Batstone et al. (2002a,b)

Como pode ser observado na Tabela 34 os conteúdos de carbono presentes no composto $(\mathrm{Cxc})$, no material inerte solúvel (Csi) e no material inerte particulado (Cxi) foram ajustados nas matrizes de equações de taxa (Tabela 11 e Tabela 12) para que se obtivesse o "fechamento" dos balanços de massa. O mesmo procedimento foi realizado em relação ao conteúdo de nitrogênio.

Os valores dos parâmetros cinéticos e físico-químicos sugeridos por Batstone et al. (2002a,b) para sistemas anaeróbios mesofílicos de alta taxa são apresentados na Tabela 35 . 
Tabela 35. Valores de parâmetros sugeridos por Batstone et al. (2002a, b)

\begin{tabular}{lcclcc}
\hline \multicolumn{1}{c}{ parâmetros } & valor & unidade & parâmetros & valor & unidade \\
\hline k_dis & 0,40 & $\mathrm{~d}^{-1}$ & k_m_c4 & 20 & $\mathrm{~d}^{-1}$ \\
k_hyd_ch & 0,25 & $\mathrm{~d}^{-1}$ & K_S_c4 & 0,3 & $\mathrm{kgDQO} \cdot \mathrm{m}^{-3}$ \\
k_hyd_pr & 0,20 & $\mathrm{~d}^{-1}$ & Y_c4 & 0,06 & - \\
k_hyd_li & 0,10 & $\mathrm{~d}^{-1}$ & K_Ih2_c4 & $1,0 \mathrm{E}-05$ & $\mathrm{kgDQO} \cdot \mathrm{m}^{-3}$ \\
k_dec_Xsu & 0,02 & $\mathrm{~d}^{-1}$ & k_m_pro & 13 & $\mathrm{~d}^{-1}$ \\
k_dec_Xaa & 0,02 & $\mathrm{~d}^{-1}$ & K_S_pro & 0,3 & $\mathrm{kgDQO} \cdot \mathrm{m}^{-3}$ \\
k_dec_Xfa & 0,02 & $\mathrm{~d}^{-1}$ & Y_pro & 0,04 & $\mathrm{~d}^{-1}$ \\
k_dec_Xc4 & 0,02 & $\mathrm{~d}^{-1}$ & K_Ih2_pro & $3,50 \mathrm{E}-06$ & $\mathrm{~d}^{-1}$ \\
k_dec_Xpro & 0,02 & $\mathrm{~d}^{-1}$ & k_m_ac & 8 & $\mathrm{~d}^{-1}$ \\
k_dec_Xac & 0,02 & $\mathrm{~d}^{-1}$ & K_S_ac & 0,15 & $\mathrm{kgDQO} \cdot \mathrm{m}^{-3}$ \\
k_dec_Xh & 0,02 & $\mathrm{~d}^{-1}$ & Y_ac & 0,05 & - \\
K_S_IN & 0,0001 & M & K_I_nh3 & 0,0018 & $\mathrm{M}$ \\
k_m_su & 30 & $\mathrm{~d}^{-1}$ & k_m_h2 & 35 & $\mathrm{~d}^{-1}$ \\
K_S_su & 0,50 & kgDQO.m & K_S_h2 & $2,50 \mathrm{E}-05$ & $\mathrm{kgDQO} . \mathrm{m}^{-3}$ \\
Y_su & 0,10 & - & Y_h2 & 0,06 & - \\
k_m_aa & 50 & $\mathrm{~d}^{-1}$ & pH_UL_aa & 5,5 & - \\
K_S_aa & 0,30 & kgDQO.m & pH_LL_aa & 4 & - \\
Y_aa & 0,08 & - & pH_UL_ac & 7 & - \\
k_m_fa & 6 & $\mathrm{~d}^{-1}$ & pH_LL_ac & 6 & - \\
K_S_fa & 0,40 & kgDQO.m & pH_UL_h2 & 6 & - \\
Y_fa & 0,06 & - & pH_LL_h2 & 5 & - \\
K_Ih2_fa & 0,000005 & kgDQO.m & & & \\
\hline
\end{tabular}

Fonte: adaptado de Batstone et al. (2002a,b)

A Tabela 36 apresenta os valores e as unidades das variáveis de estado do substrato (afluente, arquivo inputdata.m) e do efluente que compõem o vetor de inicialização. $\mathrm{O}$ vetor de inicialização corresponde ao conjunto de dados aplicados como primeiro teste (chute inicial) para as simulações. É válido ressaltar que esse conjunto de dados deve apresentar similaridade com o conjunto de dados experimentais do efluente obtidos com a operação do reator (arquivo adml.m) para reduzir o número de simulações necessárias para obtenção do conjunto otimizado dos parâmetros. 
Tabela 36. Valores e unidades das variáveis de estado do substrato (afluente) e do efluente (vetor de inicialização)

\begin{tabular}{|c|c|c|c|c|c|c|c|}
\hline $\begin{array}{c}\text { variável de } \\
\text { estado }\end{array}$ & afluente & valor & unidade & $\begin{array}{c}\text { variável de } \\
\text { estado }\end{array}$ & efluente & valor & unidade \\
\hline 1 & Ssu, in & $3,89 \mathrm{E}-02$ & kgDQO. $\mathrm{m}^{-3}$ & 1 & Ssu & $4,65 \mathrm{E}-03$ & kgDQO.m ${ }^{-3}$ \\
\hline 2 & Saa, in & 1,94E-01 & kgDQO. $\mathrm{m}^{-3}$ & 2 & Saa & $1,04 \mathrm{E}-02$ & kgDQO. $\mathrm{m}^{-3}$ \\
\hline 3 & $\mathrm{Sfa}$, in & $1,97 \mathrm{E}-01$ & kgDQO. $\mathrm{m}^{-3}$ & 3 & Sfa & $2,02 \mathrm{E}-01$ & kgDQO. $\mathrm{m}^{-3}$ \\
\hline 4 & Sva, in & $2,34 \mathrm{E}-02$ & kgDQO. $\mathrm{m}^{-3}$ & 4 & Sva & $2,52 \mathrm{E}-03$ & kgDQO.m ${ }^{-3}$ \\
\hline 5 & Sbu, in & $1,65 \mathrm{E}-02$ & kgDQO. $\mathrm{m}^{-3}$ & 5 & Sbu & $2,35 \mathrm{E}-03$ & kgDQO. $\mathrm{m}^{-3}$ \\
\hline 6 & Spro, in & $2,39 \mathrm{E}-02$ & kgDQO.m ${ }^{-3}$ & 6 & Spro & $4,03 \mathrm{E}-03$ & kgDQO.m ${ }^{-3}$ \\
\hline 7 & Sac, in & $5,56 \mathrm{E}-02$ & kgDQO. $\mathrm{m}^{-3}$ & 7 & $\mathrm{Sac}$ & $1,01 \mathrm{E}-01$ & kgDQO.m ${ }^{-3}$ \\
\hline 8 & Sh2, in & - & - & 8 & Sh2 & $2,41 \mathrm{E}-07$ & kgDQO. $\mathrm{m}^{-3}$ \\
\hline 9 & Sch 4 , in & - & - & 9 & Sch4 & 4,93E-02 & kgDQO.m $\mathrm{m}^{-3}$ \\
\hline 10 & $\mathrm{SIC}$, in & $3,50 \mathrm{E}-02$ & $\mathrm{kmolC} \cdot \mathrm{m}^{-3}$ & 10 & SIC & $3,15 \mathrm{E}-02$ & $\mathrm{kmolC} \cdot \mathrm{m}^{-3}$ \\
\hline 11 & SIN, in & $6,00 \mathrm{E}-03$ & $\mathrm{kmolN} \cdot \mathrm{m}^{-3}$ & 11 & SIN & $4,19 \mathrm{E}-03$ & $\mathrm{kmolN} \cdot \mathrm{m}^{-3}$ \\
\hline 12 & SI, in & $1,22 \mathrm{E}-01$ & kgDQO.m ${ }^{-3}$ & 12 & SI & $1,65 \mathrm{E}+01$ & kgDQO. $\mathrm{m}^{-3}$ \\
\hline 13 & $\mathrm{Xxc}$, in & 5,53E-01 & kgDQO. $\mathrm{m}^{-3}$ & 13 & $\mathrm{Xxc}$ & $5,16 \mathrm{E}-02$ & kgDQO.m ${ }^{-3}$ \\
\hline 14 & $\mathrm{Xch}$, in & $3,21 \mathrm{E}-02$ & kgDQO. $\mathrm{m}^{-3}$ & 14 & Xch & $1,78 \mathrm{E}-02$ & kgDQO.m ${ }^{-3}$ \\
\hline 15 & $\mathrm{Xpr}$, in & 1,94E-01 & kgDQO. $\mathrm{m}^{-3}$ & 15 & $\mathrm{Xpr}$ & $1,08 \mathrm{E}-01$ & kgDQO. $\mathrm{m}^{-3}$ \\
\hline 16 & $\mathrm{Xli}$, in & $2,04 \mathrm{E}-01$ & kgDQO. $\mathrm{m}^{-3}$ & 16 & Xli & $1,69 \mathrm{E}-01$ & kgDQO.m ${ }^{-3}$ \\
\hline 17 & $\mathrm{Xsu}$, in & - & - & 17 & Xsu & $8,55 \mathrm{E}-01$ & kgDQO.m ${ }^{-3}$ \\
\hline 18 & $\mathrm{Xaa}$, in & - & - & 18 & Xaa & $6,37 \mathrm{E}-01$ & kgDQO. $\mathrm{m}^{-3}$ \\
\hline 19 & $X f a$, in & - & - & 19 & Xfa & $6,73 \mathrm{E}-01$ & kgDQO.m ${ }^{-3}$ \\
\hline 20 & $\mathrm{Xc} 4$, in & - & - & 20 & $\mathrm{Xc4}$ & $2,83 \mathrm{E}-01$ & kgDQO.m $\mathrm{m}^{-3}$ \\
\hline 21 & $\mathrm{Xpro}$, in & - & - & 21 & Xpro & $1,36 \mathrm{E}-01$ & kgDQO. $\mathrm{m}^{-3}$ \\
\hline 22 & $\mathrm{Xac}$, in & - & - & 22 & Xac & $9,01 \mathrm{E}-01$ & kgDQO.m ${ }^{-3}$ \\
\hline 23 & $\mathrm{Xh} 2$, in & - & - & 23 & Xh2 & $4,36 \mathrm{E}-01$ & kgDQO.m ${ }^{-3}$ \\
\hline 24 & $\mathrm{XI}$, in & $1,23 \mathrm{E}-01$ & kgDQO. $\mathrm{m}^{-3}$ & 24 & XI & $4,38 \mathrm{E}-02$ & kgDQO.m ${ }^{-3}$ \\
\hline 25 & Scat & $2,50 \mathrm{E}-02$ & kmol.m $\mathrm{m}^{-3}$ & 25 & Scat & $3,64 \mathrm{E}-02$ & kmol.m ${ }^{-3}$ \\
\hline 26 & San & $1,00 \mathrm{E}-03$ & kmol. $\mathrm{m}^{-3}$ & 26 & San & $3,25 \mathrm{E}-03$ & kmol.m ${ }^{-3}$ \\
\hline 27 & Sva- & - & - & 27 & Sva- & $1,08 \mathrm{E}-02$ & $\mathrm{kgDQO} \cdot \mathrm{m}^{-3}$ \\
\hline 28 & Sbu- & - & - & 28 & Sbu- & $1,41 \mathrm{E}-02$ & kgDQO.m ${ }^{-3}$ \\
\hline 29 & Spro- & - & - & 29 & Spro- & $1,67 \mathrm{E}-02$ & kgDQO.m ${ }^{-3}$ \\
\hline 30 & Sac- & - & - & 30 & Sac- & $1,81 \mathrm{E}-01$ & $\mathrm{kgDQO} \cdot \mathrm{m}^{-3}$ \\
\hline 31 & Shco3- & - & - & 31 & Shco3- & $8,37 \mathrm{E}-02$ & $\mathrm{kmolC} \cdot \mathrm{m}^{-3}$ \\
\hline 32 & Sco2 & - & - & - & $\mathrm{Sco} 2$ & $1,11 \mathrm{E}-02$ & $\mathrm{kmolC} \cdot \mathrm{m}^{-3}$ \\
\hline 33 & Snh3 & - & - & 32 & Snh3 & $3,83 \mathrm{E}-03$ & kmolN.m ${ }^{-3}$ \\
\hline 34 & Snh4+ & - & - & - & Snh4+ & $2,26 \mathrm{E}-01$ & $\mathrm{kmolN} \cdot \mathrm{m}^{-3}$ \\
\hline 35 & $\mathrm{SH}+$ & - & - & 33 & $\mathrm{SH}+$ & $6,56 \mathrm{E}-08$ & kmol.m $\mathrm{m}^{-3}$ \\
\hline 36 & $\mathrm{pH}$ & - & - & - & $\mathrm{pH}$ & $7,18 \mathrm{E}+00$ & - \\
\hline 37 & Sgas,h2 & - & - & 34 & Sgas,h2 & $9,66 \mathrm{E}-06$ & kgDQO. $\mathrm{m}^{-3} / \mathrm{bar}$ \\
\hline 38 & Sgas,ch4 & - & - & 35 & Sgas,ch4 & $1,38 \mathrm{E}+00$ & kgDQO. $\mathrm{m}^{-3} / \mathrm{bar}$ \\
\hline 39 & Sgas,co2 & - & - & 36 & Sgas,co2 & $1,59 \mathrm{E}-02$ & kgDQO. $\mathrm{m}^{-3} / \mathrm{bar}$ \\
\hline 40 & qgas & - & - & - & qgas & $1,70 \mathrm{E}+03$ & $\mathrm{~m}^{3} \cdot \mathrm{d}^{-1}$ \\
\hline
\end{tabular}

Fonte: adaptado de Batstone et al. (2002a,b)

Primeiramente os resultados experimentais obtidos com o monitoramento do reator UASB em estado de equilíbrio dinâmico aparente e operado com vazão média afluente de $16 \mathrm{~L}^{-1}{ }^{-1}$, TDH de $10 \mathrm{~h}$ e velocidade ascensional de $0,23 \mathrm{~m} \cdot \mathrm{h}^{-1}$ foram aplicados como dados de entrada para as simulações do ADM1. 
Não foi verificada produção de biogás nas primeiras simulações e os valores dos parâmetros relativos às concentrações de microrganismos (Xsu, Xaa, Xfa, Xc4, Xpro, Xac, Xh2) resultaram iguais a zero ou a valores negativos.

Embora Bastone et al. (2002a, b) proponham valor de tempo de retenção celular igual a $40 \mathrm{~d}^{-1}$, o ADM1 considera a igualdade entre o tempo de retenção celular $(\theta c)$ e o tempo de detenção hidráulica. Assim, foi necessário contemplar a diferença entre esses parâmetros nas equações de balanço de massa dos componentes particulados do modelo (equações 85 a 96, APÊNDICE 8.2).

Diversas simulações foram realizadas considerando $\theta \mathrm{c}$ igual a TDH de $10 \mathrm{~h}$ (0,4 d) e variável em 50 d e 100 d.

Os parâmetros cinéticos k_dis (desintegração do composto particulado), k_hyd_ch (desintegração de carboidratos), k_hyd_pr (desintegração de proteínas) e k_hyd_li (desintegração de lipídeos) iguais a $0,24 \mathrm{~h}^{-1}, 0,79 \mathrm{~h}^{-1}, 0,2 \mathrm{~h}^{-1}$ e 1,75 $\mathrm{h}^{-1}$ representaram o conjunto de parâmetros otimizados que indicou melhor similaridade entre os resultados simulados e os observados para DQO efluente, $\mathrm{pH}$, concentração de ácidos voláteis e alcalinidade a bicarbonato.

A Tabela 37 apresenta os valores obtidos experimentalmente e nas simulações do ADM1 para DQO bruta, pH, concentração de ácidos voláteis e alcalinidade a bicarbonato no efluente.

Tabela 37. Condições operacionais aplicadas nas simulações do ADM1, resultados observados (experimentalmente) e calculados nas simulações.

\begin{tabular}{|c|c|c|c|c|c|c|}
\hline simulações & $\begin{array}{l}\text { TDH } \\
\text { (h) }\end{array}$ & $\begin{array}{l}\theta \mathrm{c} \\
\text { (d) }\end{array}$ & $\begin{array}{c}\text { DQOe } \\
\left(\mathrm{mg} . \mathrm{L}^{-1}\right)\end{array}$ & $\begin{array}{c}\mathrm{pH} \\
-\end{array}$ & $\begin{array}{l}\text { ácidos voláteis } \\
\left(\mathrm{mgHAc} . \mathrm{L}^{-1}\right)\end{array}$ & $\begin{array}{l}\text { alcalinidade a bicarbonato } \\
\left(\mathrm{mgCaCO}_{3} \cdot \mathrm{L}^{-1}\right)\end{array}$ \\
\hline obs. & 10 & 40 & 103 a 546 & 6,3 a 7,4 & 14 a $112\left(46^{*}\right)$ & 108 a $337(189 *)$ \\
\hline calc 1 & 10 & 0,4 & $260 *$ a 474 & 6,0 a $8,0(6,9)$ & 52 a $62(52)$ & 97 a 106 \\
\hline calc 2 & 10 & 50 & 265 a 281 & 5,5 a $6,4(6,4)$ & 36 a $75(72)$ & 109 a 140 \\
\hline calc 3 & 10 & 100 & 265 a 291 & 5,5 a $6,5^{*}(5,5)$ & 38 a $73(71)$ & 109 a 141 \\
\hline
\end{tabular}

*valores adotados no vetor de inicialização

valores entre parênteses correspondem aos valores que o modelo convergiu

O valor de $260 \mathrm{mg} . \mathrm{L}^{-1}$ foi aplicado no vetor de inicialização do ADM1 como “chute inicial” para DQO média efluente. É possível observar na Tabela 37 que as melhores respostas do modelo em relação a DQO efluente foram obtidas para tempos de retenção celular de 50 d e de 100 d. Para esses tempos de retenção celular, o ADM1 indicou "estado de equilíbrio dinâmico aparente" do reator para valores que 
convergiram para aproximadamente $281 \mathrm{mg} . \mathrm{L}^{-1}$ e $291 \mathrm{mg} . \mathrm{L}^{-1}$, respectivamente, ou seja, diferença de $8 \%$ e $12 \%$ entre os valores de DQO efluente observados e calculados. Para $\theta \mathrm{c}$ igual a TDH de 0,4 d, a DQO efluente calculada convergiu para aproximadamente $474 \mathrm{mg} . \mathrm{L}^{-1}$, ou seja, diferença de aproximadamente $79 \%$ entre os valores observados e calculados (Figura 34.a).

Foi possível observar a não representatividade da média aritmética dos dados experimentais observados no monitoramento do reator devido à variabilidade horária e diária de alguns parâmetros, tais como a DQO afluente (RESULTADOS E DISCUSSÃO 5.6). Como o modelo ADM1 considera apenas a média aritmética dos valores dos parâmetros de entrada e saída, houve dificuldade para implementação dos resultados experimentais na matriz de equações de taxa e comparação entre os resultados observados e os simulados pelo modelo.

Ao comparar os resultados observados e os obtidos para $\mathrm{pH}$ no efluente, foi possível notar similaridade na resposta do modelo com valores que convergiram para 6,9, 6,5 e 5,5 nas simulações com $\theta \mathrm{c}$ igual a TDH, $50 \mathrm{~d}$ e $100 \mathrm{~d}$, respectivamente. Os valores de $\mathrm{pH}$ diminuíram com o aumento do tempo de retenção celular de $50 \mathrm{~d}$ para 100 d (Figura 34.b). Foi possível verificar que a maior similaridade entre os resultados experimentais e os simulados ocorreu para $\theta \mathrm{c}$ igual a $100 \mathrm{~d}$.

Como o ADM1 calcula separadamente as concentrações dos ácidos acético, butírico, propiônico e valérico em $\mathrm{kgDQO} . \mathrm{m}^{-3}$, foi necessário converter as concentrações dos ácidos em mgDQO.L ${ }^{-1}$ e posteriormente em mgHAc. $\mathrm{L}^{-1}$ para que pudessem ser comparadas com as concentrações observadas experimentalmente. A mesma resposta do modelo foi observada para a concentração de ácidos voláteis no efluente, uma vez que os resultados convergiram para $52 \mathrm{mgHAc} . \mathrm{L}^{-1}, 72 \mathrm{mgHAc} . \mathrm{L}^{-1}$ e $71 \mathrm{mgHAc} . \mathrm{L}^{-1}$ para $\theta \mathrm{c}$ igual a $0,4 \mathrm{~d}, 50 \mathrm{~d}$ e $100 \mathrm{~d}$, respectivamente (Figura 34.c). Os resultados calculados pelo modelo foram ligeiramente superiores à média dos valores observados experimentalmente e que foi aplicada como valor inicial para o vetor de inicialização do ADM1.

Parker (2005) ressaltou que o modelo apresenta tendência de superestimar as concentrações de ácidos voláteis para reatores operados com pequenos tempos de retenção celular. $\mathrm{O}$ autor destacou ainda, a importância da qualidade da caracterização do afluente em relação às concentrações de amônia e de nitrogênio 
total a serem aplicadas no modelo, devido a influencia no tamponamento do $\mathrm{pH}$ e nas funções de inibição do modelo.

Os valores obtidos para a alcalinidade a bicarbonato no efluente variaram de 97 a $106 \mathrm{mgCaCO}_{3} \cdot \mathrm{L}^{-1}$ para $\theta \mathrm{c}$ igual a $0,4 \mathrm{~d}$ e de 109 a $141 \mathrm{mgCaCO}_{3} \cdot \mathrm{L}^{-1}$ para $\theta \mathrm{c}$ igual a $50 \mathrm{~d}$ e $100 \mathrm{~d}$ (Tabela 37). O modelo indicou a capacidade de tamponamento do reator mesmo com o aumento da concentração de ácidos voláteis no efluente e a queda no pH quando foi aplicado $\theta \mathrm{c}$ de $100 \mathrm{~d}$ (Figura 34.d).

O modelo indicou produção gasosa em termos de hidrogênio, metano e dióxido de carbono de aproximadamente $0,1 \mathrm{~L}^{-1} \mathrm{~h}^{-1}$ quando foi aplicado $\theta \mathrm{c}$ igual a $0,4 \mathrm{~d}$, provavelmente devido à baixa concentração de biomassa presente no interior do reator para que ocorresse a digestão anaeróbia. Por outro lado, quando foram adotados valores de tempo de retenção celular iguais a 50 d e 100 d nas equações de balanço de massa, o modelo indicou produção gasosa de aproximadamente $0,5 \mathrm{~L} \cdot \mathrm{h}^{-1}$.

Em todas as simulações, independentemente do valor do tempo de retenção celular adotado, a concentração de biomassa ativa variou de $6910 \mathrm{mgDQO} . \mathrm{L}^{-1}$ a 9600 mgDQO.L ${ }^{-1}$ no efluente do reator. Queen (2006) verificou o mesmo comportamento nas simulações de um reator UASB hipotético tratando esgoto doméstico com DQO de $600 \mathrm{mg} . \mathrm{L}^{-1}$, porém justificou as elevadas concentrações de sólidos como concentrações presentes no interior e não no efluente do reator.

A Figura 34 apresenta os resultados observados experimentalmente e os simulados com o modelo ADM1 para DQO bruta, pH, concentração de ácidos voláteis e alcalinidade a bicarbonato no efluente. 


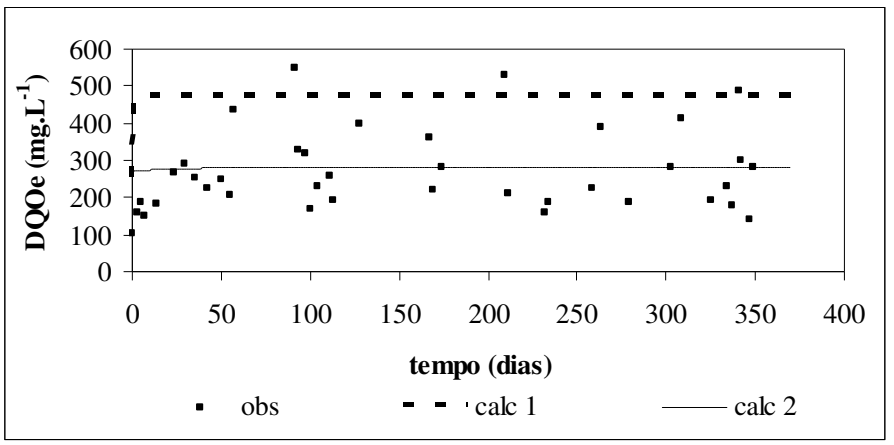

(a)

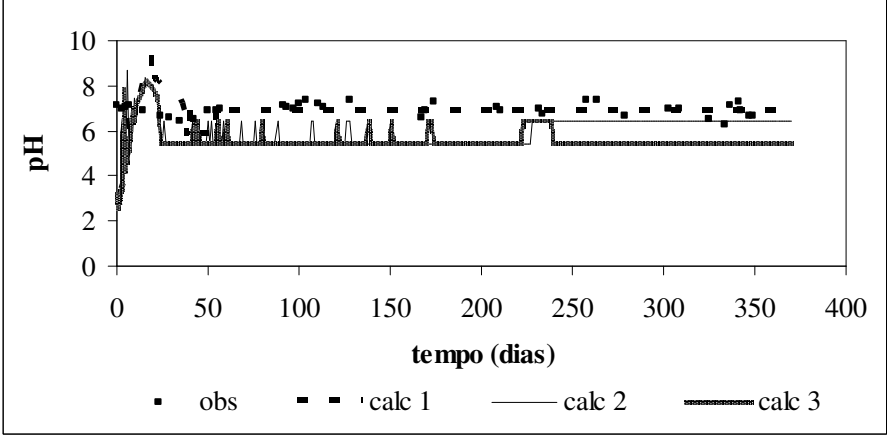

(b)

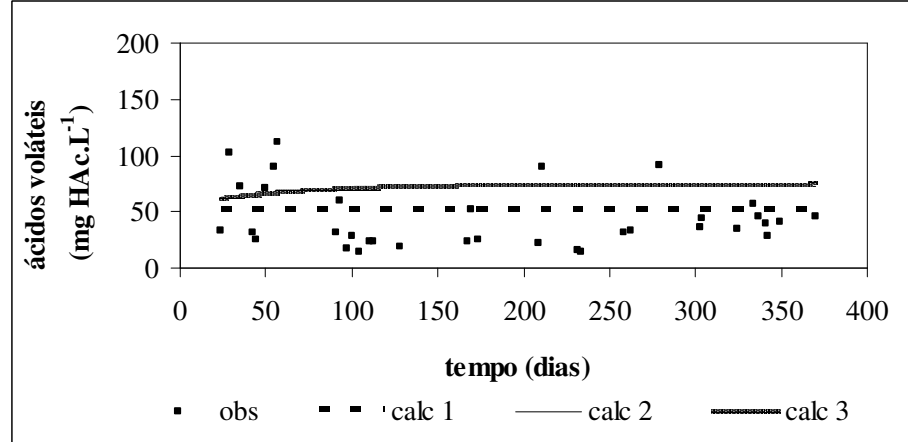

(c)

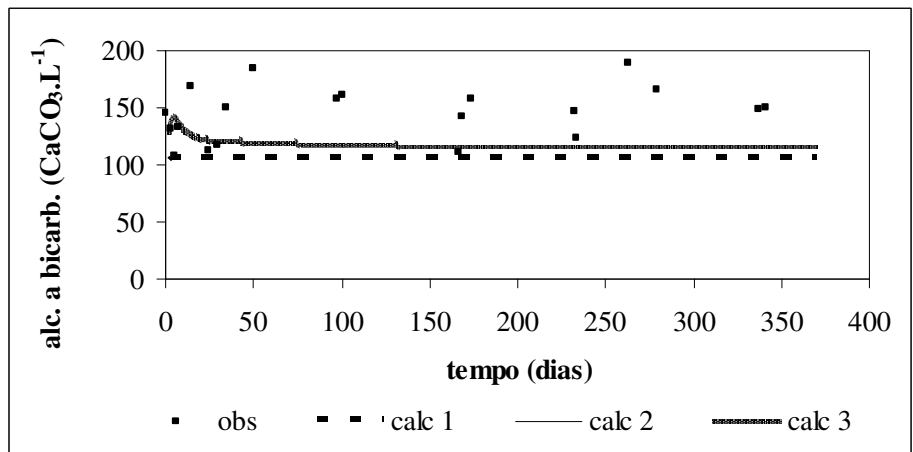

(d)

Figura 34. Valores de a) DQO bruta, b) pH, c) concentração de ácidos voláteis, d) alcalinidade a bicarbonato dos resultados observados e calculados (calc 1 $\theta c=0,4 d$; calc $2-\theta c=50 \mathrm{~d}$; calc $3-\theta c=100 \mathrm{~d}$ ) para 0 efluente 
Foi possível observar pequena similaridade entre os valores simulados e os experimentais do efluente, sendo ainda necessário maior número de aplicações do modelo no tratamento de esgotos domésticos.

Diversas dificuldades foram encontradas durante a realização das simulações com o modelo ADM1. Os maiores desafios encontrados foram:

- A composição complexa do esgoto doméstico acarretou na necessidade de conversão das variáveis correspondentes aos resultados experimentais de acordo com àquelas exigidas pelo modelo, a fim de possibilitar sua aplicação como dados de entrada do ADM1;

- O fracionamento da matéria orgânica afluente a ser implementado como conjunto de variáveis de estado e como vetor de inicialização no modelo. Bastone et al. (2002a, b) propuseram fracionamento da DQO bruta afluente em $30 \%$ de carboidratos, $30 \%$ de proteínas, $30 \%$ de lipídeos e $10 \%$ de inertes, o que não representou a situação observada pela determinação dos parâmetros de monitoramento do sistema. O fracionamento da DQO bruta no substrato estudado apresentou em média $6 \%$ de carboidratos, $35 \%$ de proteínas, 37\% de lipídeos e $22 \%$ de material inerte;

- A suplementação do esgoto bruto com esgoto sintético aumentou ainda mais a diferença entre o fracionamento proposto por Batstone et al. (2002a, b) e o observado experimentalmente;

- A estimativa de alguns parâmetros no modelo que não foram determinados experimentalmente, nas formas solúvel e/ou particulada, devido à extensa campanha realizada para monitoramento do comportamento do reator (DQO bruta e filtrada, $\mathrm{pH}$, alcalinidade total e a bicarbonato, ácidos voláteis, sólidos totais e suspensos, nitrogênio total e amoniacal, composição e produção de biogás, dentre outros). A estimativa dos parâmetros não determinados foi aplicada tanto no arquivo de entrada (dados do afluente) quanto no vetor de inicialização (chute inicial) do ADM1. Dentre esses parâmetros, destacaram-se concentração de monossacarídeos, aminoácidos, ácidos 
graxos, carbono inorgânico, nitrogênio inorgânico, cátions e ânions, dentre outros;

\subsection{CALIBRAÇÃO E VALIDAÇÃO DO MODELO MMS}

O ajuste da variação da DQO afluente ao longo do tempo resultou em equações polinomiais de diferentes ordens que foram aplicadas no modelo MMS (Tabela 38). O ajuste foi realizado para todos os perfis de amostragem temporal pois ao longo de todo o experimento houve variação da concentração da DQO afluente em função da variabilidade da concentração da matéria orgânica , conforme discutido nos itens 5.2, 5.3, 5.4 e 5.5.

Apenas os resultados dos perfis 5 e 7 não foram aplicados como dados de entrada nas simulações com o MMS por corresponderem ao primeiro dia de aplicação das variações cíclicas senoidais da vazão afluente em 40\% e 60\%, respectivamente.

A função objetivo $(F)$ minimizou a diferença entre os valores experimentais e teóricos da DQO efluente obtidos no decorrer do período operacional do reator e com as simulações do modelo MMS, respectivamente. Com a minimização da diferença foi possível obter valor otimizado da constante cinética aparente de $1^{\mathrm{a}}$ ordem para todos os perfis de amostragem temporal realizados ao longo da operação do reator UASB. Os valores da constante cinética de $1^{\mathrm{a}}$ ordem obtidos com a otimização foram aplicados nas simulações do modelo MMS (Tabela 38).

A Tabela 38 apresenta as equações de variação de DQO afluente ao longo do tempo e os valores otimizados das constantes cinéticas aparentes de $1^{\mathrm{a}}$ ordem para os perfis de amostragem temporal de 1, 2, 3, 4, 6 e 8 . 
Tabela 38. Equações da variação de DQO ao longo do tempo, coeficientes de correlação e valores otimizados de $\mathbf{k}_{1}$

\begin{tabular}{|c|c|}
\hline perfil & Equação da variação de DQO $\left(\mathrm{mg} . \mathrm{L}^{-1}\right) \mathrm{x}$ tempo (hora) \\
\hline $\begin{array}{c}1 \\
\text { (etapa I) }\end{array}$ & $\begin{aligned} & D Q O_{a}=0,0085 t^{5}-0,2878 t^{4}+3,3889 t^{3}-15,884 t^{2}+5,5422 t+581,48 \\
&\left(\mathrm{R}^{2}=1\right) \\
& \mathrm{k}_{1} \text { otimizado }= 0,63 \mathrm{~h}^{-1}(\mathrm{~F}=75776)\end{aligned}$ \\
\hline $\begin{array}{c}2 \\
\text { (etapa I) }\end{array}$ & $\begin{array}{c}D Q O_{a}=0,0005 t^{6}-0,0317 t^{5}+0,8452 t^{4}-11,107 t^{3}+75,037 t^{2}-251,38 t+968,76 \\
\left(\mathrm{R}^{2}=0,998\right) \\
\mathrm{k}_{1} \text { otimizado }=0,62 \mathrm{~h}^{-1}(\mathrm{~F}=21817)\end{array}$ \\
\hline $\begin{array}{c}3 \\
\text { (etapa II) }\end{array}$ & $\begin{aligned} D Q O_{a}=-0,0131 t^{4}+0,344 t^{3}- & 2,3133 t^{2}-1,3846 t+632,63 \\
& \left(\mathrm{R}^{2}=1\right) \\
\mathrm{k}_{1} \text { otimizado }= & 0,61 \mathrm{~h}^{-1}(\mathrm{~F}=17942)\end{aligned}$ \\
\hline $\begin{array}{c}4 \\
\text { (etapa II) }\end{array}$ & $\begin{array}{c}D Q O_{a}=-0,0131 t^{4}+0,344 t^{3}-2,3133 t^{2}-1,3846 t+632,63 \\
\left(\mathrm{R}^{2}=0,999\right) \\
\mathrm{k}_{1} \text { otimizado }=0,62 \mathrm{~h}^{-1}(\mathrm{~F}=47060)\end{array}$ \\
\hline $\begin{array}{c}6 \\
\text { (etapa III) }\end{array}$ & $\begin{array}{c}D Q O_{a}=-0,001 t^{6}+0,0606 t^{5}-1,329 t^{4}+13,08 t^{3}-56,637 t^{2}+72,862 t+910,36 \\
\left(\mathrm{R}^{2}\right)=0,8628 \\
\mathrm{k}_{1} \text { otimizado }=0,52 \mathrm{~h}^{-1}(\mathrm{~F}=70338)\end{array}$ \\
\hline $\begin{array}{c}8 \\
\text { (etapa IV) }\end{array}$ & $\begin{array}{c}D Q O_{a}=0,0003 t^{6}-0,0233 t^{5}+0,6375 t^{4}-8,3953 t^{3}+53,738 t^{2}-152,7 t+729,3 \\
\left(\mathrm{R}^{2}\right)=1 \\
\mathrm{k}_{1} \text { otimizado }=0,22 \mathrm{~h}^{-1}(\mathrm{~F}=8005)\end{array}$ \\
\hline
\end{tabular}

Nota: $t$ corresponde ao tempo em horas

Pela Tabela 38 é possível observar que os valores obtidos para a constante cinética aparente de $1^{\mathrm{a}}$ ordem resultaram de aproximadamente $0,61 \mathrm{~h}^{-1}$ a $0,63 \mathrm{~h}^{-1}$ nos perfis de 1 a 4, ou seja, quando o reator UASB foi operado com vazão constante nas etapas I e II, conforme verificado na Figura 16, Figura 17, Figura 19 e Figura 21. Apesar do arraste de sólidos mais evidente nos perfis 2 e 3 quando comparados aos perfis 1 e 4 , não houve diferença entre os valores de $\mathrm{k}_{1}$ obtidos.

Com a aplicação da variação cíclica da vazão afluente de $40 \%$ e de $60 \%$, os valores obtidos de $\mathrm{k}_{1}$ foram iguais a $0,52 \mathrm{~h}^{-1}$ e $0,22 \mathrm{~h}^{-1}$, respectivamente.

É possível verificar que os valores de $\mathrm{k}_{1}$ diminuíram em aproximadamente $15 \%$ e $64 \%$ quando o reator foi submetido a variações da vazão afluente de $40 \%$ e $60 \%$, respectivamente. A diminuição pode estar relacionada ao menor tempo de contato entre os microrganismos e o substrato, devido à aplicação de maiores velocidades ascensionais e menores valores de TDH. Além disso, velocidades ascensionais mais elevadas podem ter aumentado o arraste de sólidos no efluente do 
reator, reduzindo conseqüentemente a concentração de biomassa no reator e os valores de $\mathrm{k}_{1}$.

Batstone et al. (2002a,b) sugeriram no modelo ADM1 constante cinética de $1^{\mathrm{a}}$ ordem igual a $0,4 \mathrm{~d}^{-1}$ para reatores anaeróbios mesofílicos tratando esgoto doméstico.

Zaiat et al. (2000) e Vieira et al. (1997) obtiveram parâmetros cinéticos

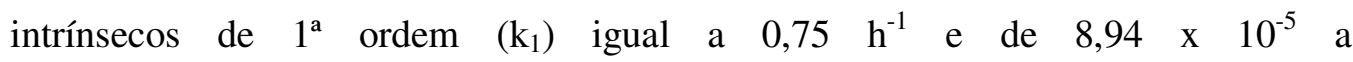
$1,51 \mathrm{~h}^{-1} \times 10^{-5} \mathrm{~L} \cdot \mathrm{mgSSV}^{-1} \cdot \mathrm{h}^{-1}$, respectivamente, para reator anaeróbio horizontal de leito fixo tratando esgoto doméstico.

Castillo et al. (1999) observaram que o modelo cinético de $1^{\text {a }}$ ordem foi o que melhor ajustou os resultados experimentais de um reator UASB tratando esgoto doméstico com DQO afluente de aproximadamente $650 \mathrm{mg} . \mathrm{L}^{-1}$ no inverno $\left(13^{\circ} \mathrm{C}\right) \mathrm{e}$ no verão $\left(20^{\circ} \mathrm{C}\right)$. Os autores obtiveram valores de $\mathrm{k}_{1}$ iguais a $0,24 \mathrm{~h}^{-1}$ para TDH de $6 \mathrm{~h}$ e $\mathrm{T}$ de $20^{\circ} \mathrm{C}$ e $0,15 \mathrm{~h}^{-1}$ para $\mathrm{TDH}$ de $7,5 \mathrm{~h}$ e $\mathrm{T}$ de $13^{\circ} \mathrm{C}\left(\mathrm{R}^{2}=0,95\right)$.

Tommaso et al. (2003) estudaram a influência do substrato sintético na degradação anaeróbia de proteína em reator anaeróbio horizontal de leito fixo de $2 \mathrm{~L}$ (TDH de 4 h). O substrato era composto por mistura de soroalbumina, amido, glicose e lipídeos com DQO de aproximadamente $600 \mathrm{mg} . \mathrm{L}^{-1}$. Com ajuste do modelo cinético de $1^{\mathrm{a}}$ ordem, os autores verificaram valores de $\mathrm{k}_{1}$ iguais a $0,85 \mathrm{~h}^{-1}$ para a etapa acidogênica (propionato) e $0,67 \mathrm{~h}^{-1}$ para etapa acetogência $\left(\mathrm{R}^{2}=0,984\right)$.

A Figura 35 e a Figura 36 apresentam os resultados observados e calculados da variação da DQO efluente ao longo do tempo para os perfis 1, 2, 3, 4, 6 e 8 . 


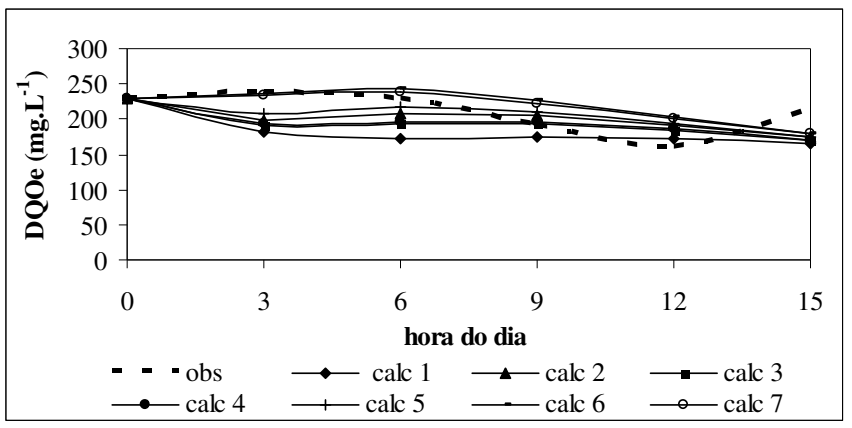

(a)

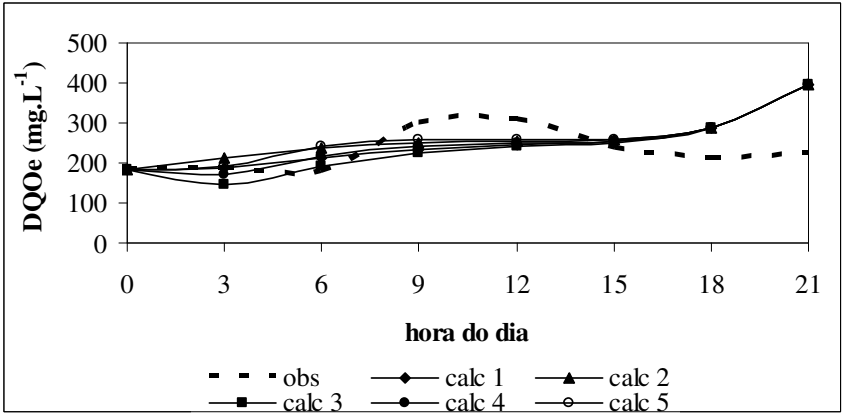

(b)

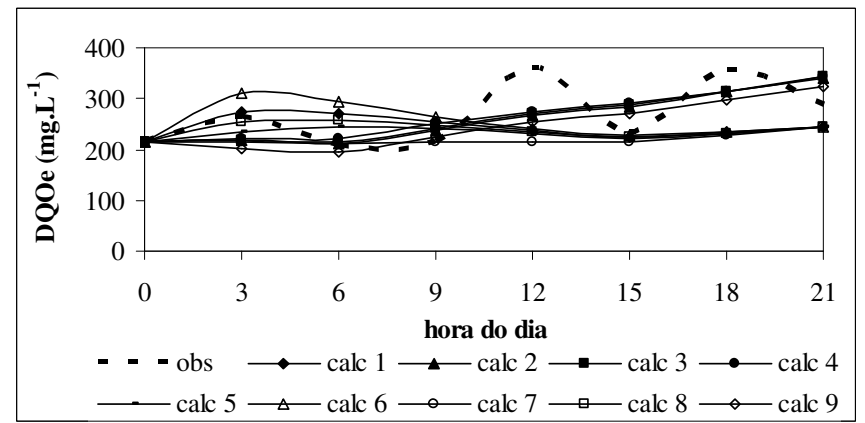

(c)

Figura 35. Resultados da variação de DQO efluente ao longo do tempo observados e calculados nos perfis de $24 \mathrm{~h}$ de amostragem temporal do reator: ETAPAS I e II (TDH e Vasc = constante) a) perfil 1; b) perfil 2; c) perfil 3 


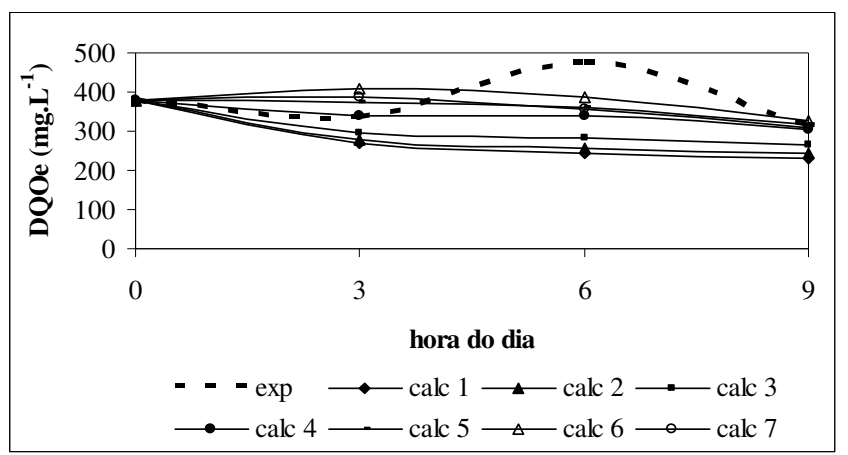

(a)

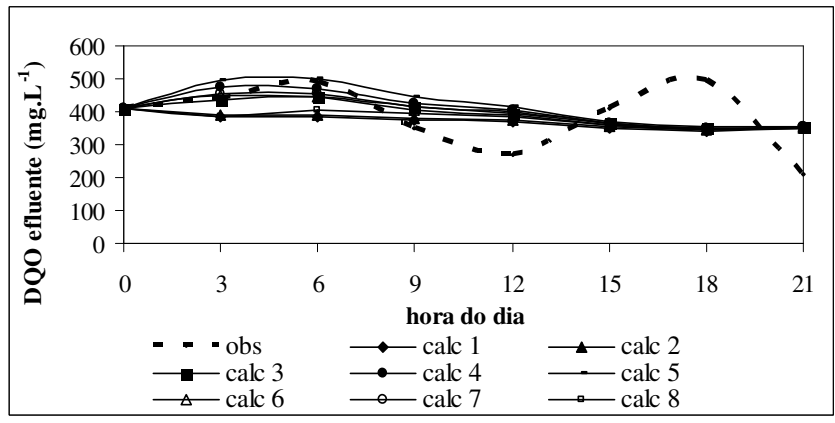

(b)

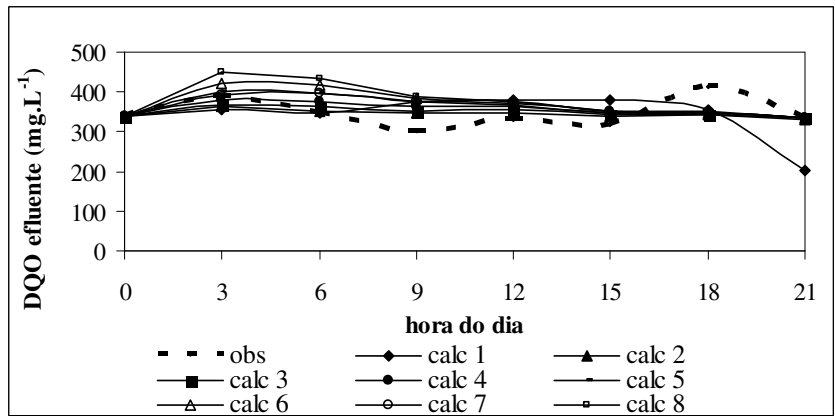

(c)

Figura 36. Resultados da variação de DQO efluente ao longo do tempo observados e calculados nos perfis de $24 \mathrm{~h}$ de amostragem temporal do reator: ETAPAS I e II (TDH e Vasc $=$ constante) a) perfil 4; ETAPA III (TDH, Vasc variável, $40 \%$ Q) b) perfil 6; ETAPA IV c) perfil 8

As simulações do MMS foram realizadas fixando os valores de DQO no efluente e de SSV no reator na rotina computacional desenvolvida no Matlab (APÊNDICE 8.3). Assim foi possível realizar diversas simulações com os parâmetros cinéticos otimizados e obter faixas de valores de DQO efluente ao longo do tempo para o último compartimento do reator. Apenas os valores obtidos para o último compartimento estão representados graficamente uma vez que esses valores correspondem ao último reator N-CSTR em série. 
Ao comparar os resultados observados e os calculados é possível observar que o modelo indicou faixa de valores para DQO efluente de 162 a $229 \mathrm{mg} . \mathrm{L}^{-1}$ para perfil 1(Figura 35 a.); 148 a 398 mg.L $\mathrm{L}^{-1}$ para perfil 2 (Figura 35 b.) ; 214 a $311 \mathrm{mg} . \mathrm{L}^{-1}$ para perfil 3 (Figura 35 c.) e 232 a 409 mg.L -1 $^{-1}$ para perfil 4 (Figura 36 a.). As faixas de valores obtidas nas simulações resultaram em diferença de aproximadamente $17 \%, 48 \%, 37 \%$ e $8 \%$ para os perfis 1,23 e 4, respectivamente, em relação aos resultados observados (Tabela 39).

Os valores de DQO efluente variaram de 342 a $456 \mathrm{mg} . \mathrm{L}^{-1}$ para perfil 6 (Figura 36 b.) e de 204 a 452 mg.L - $^{-1}$ para perfil 8 (Figura 36 c.), ou seja, diferenças de aproximadamente $59 \%$ e $56 \%$, respectivamente. As maiores diferenças entre os valores observados e calculados de DQO efluente nesses perfis podem ser justificadas pelo arraste de sólidos mais significativo quando foram aplicadas variações na vazão afluente, que limitaram as respostas do MMS.

As maiores diferenças obtidas em relação aos valores da DQO efluente, observada e calculada, resultaram da limitação do modelo em considerar o arraste de sólidos no efluente que ocorreu ao longo de toda a operação do reator. Como não é possível prever o arraste de sólidos no efluente, não há como quantificar e conseqüentemente modelar a parcela "perdida" de sólidos do reator. Assim o comportamento do reator em relação à eficiência de remoção de matéria orgânica é indicado por faixa de valores de DQO efluente ao longo do tempo.

Apesar de considerar a equação da variação da DQO afluente ao longo do tempo, o modelo apresentou pequena sensibilidade em relação à variabilidade da DQO afluente ao longo do tempo.

Foi possível verificar maiores diferenças entre os valores observados e calculados de DQO efluente nos perfis 2 e 3 devido ao maior arraste de sólidos no efluente do reator nesses perfis em relação aos demais perfis das etapas I e II.

A Tabela 39 apresenta o conjunto de dados de DQO efluente observado e calculado pelo modelo MMS nos perfis 1, 2, 3, 4, 6 e 8 . 
Tabela 39. Resumo do conjunto de valores de DQO efluente (observado e calculado) ao longo do tempo nos perfis $1,2,3,4,6$ e 8

\begin{tabular}{|c|c|c|c|c|c|c|c|c|c|c|c|c|}
\hline perfil & \multicolumn{2}{|r|}{1} & \multicolumn{2}{|r|}{2} & \multicolumn{2}{|r|}{3} & \multicolumn{2}{|r|}{4} & \multicolumn{2}{|c|}{6} & \multicolumn{2}{|c|}{8} \\
\hline $\begin{array}{c}\mathrm{t} \\
\text { (h) }\end{array}$ & $\begin{array}{l}\text { DQOobs } \\
\left(\mathrm{mg.L}^{-1}\right)\end{array}$ & $\begin{array}{c}\text { DQO calc } \\
\left(\mathrm{mg.L}^{-1}\right)\end{array}$ & $\begin{array}{c}\text { DQOobs } \\
\left(\mathrm{mg.L}^{-1}\right)\end{array}$ & $\begin{array}{c}\text { DQO calc } \\
\left({\left.\mathrm{mg} . \mathrm{L}^{-1}\right)}^{-1}\right.\end{array}$ & $\begin{array}{l}\text { DQOobs } \\
\left(\mathrm{mg.L}^{-1}\right)\end{array}$ & $\begin{array}{c}\text { DQO calc } \\
\left(\text { mg.L }^{-1}\right)\end{array}$ & $\begin{array}{l}\text { DQOobs } \\
\left(\mathrm{mg}^{-\mathrm{L}^{-1}}\right)\end{array}$ & $\begin{array}{c}\text { DQO calc } \\
\left(\mathrm{mg}^{-\mathrm{L}^{-1}}\right)\end{array}$ & $\begin{array}{l}\text { DQOobs } \\
\left({\left.\mathrm{mg} . \mathrm{L}^{-1}\right)}^{-1}\right.\end{array}$ & $\begin{array}{c}\text { DQO calc } \\
\left(\mathrm{mg}^{-\mathrm{L}^{-1}}\right)\end{array}$ & $\begin{array}{c}\text { DQOobs } \\
\left(\mathrm{mg.L}^{-1}\right)\end{array}$ & $\begin{array}{c}\text { DQO calc } \\
\left(\mathrm{mg.L}^{-1}\right)\end{array}$ \\
\hline 0 & 229 & 229 & 182 & 182 & 214 & 214 & 377 & 377 & 410 & 410 & 340 & 340 \\
\hline 3 & 239 & 181 a 236 & 187 & 148 a 211 & 263 & 200 a 274 & 336 & 269 a 409 & 439 & 384 a 497 & 390 & 357 a 452 \\
\hline 6 & 228 & 174 a 242 & 179 & 190 a 242 & 207 & 196 a 295 & 475 & 242 a 385 & 489 & 385 a 498 & 348 & 347 a 436 \\
\hline 9 & 192 & 176 a 227 & 299 & 235 a 258 & 214 & 216 a 266 & 312 & 232 a 316 & 352 & 373 a 443 & 303 & 374 a 389 \\
\hline 12 & 160 & 173 a 203 & 310 & 245 a 257 & 360 & 216 a 275 & - & - & 269 & 370 a 414 & 330 & 348 a 381 \\
\hline 15 & 212 & 174 a 179 & 238 & 252 a 259 & 234 & 215 a 287 & - & - & 408 & 352 a 371 & 318 & 341 a 379 \\
\hline 18 & - & - & 214 & 287 a 290 & 355 & 228 a 316 & - & - & 494 & 342 a 353 & 411 & 343 a 354 \\
\hline 21 & - & - & 227 & 397 a 398 & 287 & 244 a 342 & - & - & 211 & 351 a 355 & 334 & 204 a 335 \\
\hline
\end{tabular}

Para validar o MMS, os dados reportados por Passig (2005) foram utilizados como dados de entrada nas simulações do modelo. O autor operou um reator UASB com TDH de 6 h, vazão média afluente constante de 3130 L.h ${ }^{-1}$ e velocidade ascensional de $0,78 \mathrm{~m} \cdot \mathrm{h}^{-1}$. O reator com volume total de $18,8 \mathrm{~m}^{3}$ trata esgoto doméstico de parte da cidade de São Carlos - SP com DQO afluente variando de aproximadamente 600 a $900 \mathrm{mg} \cdot \mathrm{L}^{-1}$.

Duas situações foram consideradas nas simulações a fim de verificar a aplicabilidade e a confiabilidade do modelo para os dados reportados por Passig (2005): a) perfil 1 para velocidade ascensional constante de $0,78 \mathrm{~m} \cdot \mathrm{h}^{-1}$ e b) perfil 2 para velocidade ascensional de $1,17 \mathrm{~m} \cdot \mathrm{h}^{-1}$ resultante de recirculação de $50 \%$ da vazão média afluente, ou seja, $1565 \mathrm{~L} \cdot \mathrm{h}^{-1}$.

A Tabela 40 apresenta as equações de variação de DQO afluente ao longo do tempo e os valores otimizados das constantes cinéticas aparentes de $1^{\mathrm{a}}$ ordem para os perfis de amostragem temporal 1 e 2 reportados por Passig (2005).

Tabela 40. Equações da variação de DQO ao longo do tempo, coeficientes de correlação e valores otimizados de $\mathbf{k}_{1}$ para dados de Passig (2005)

\begin{tabular}{cc}
\hline perfil & Equação da variação de DQO $\left(\mathrm{mg.L}^{-1}\right) \mathrm{x}$ tempo (hora) \\
\hline 1 & $D Q O a=-0,0017 t^{5}-0,4722 t^{4}+14,194 t^{3}-118,25 t^{2}+266,89 t+825$ \\
$($ etapa I) & $\left(\mathrm{R}^{2}=1\right)$ \\
& $\mathrm{k}_{1}$ otimizado $=0,79 \mathrm{~h}^{-1}(\mathrm{~F}=5445)$ \\
\hline 2 & $D Q O_{a}=-0,6103 t^{4}+17,028 t^{3}-156,09 t^{2}+465,92 t+487$ \\
(etapa II) & $\left(\mathrm{R}^{2}=1\right)$ \\
& $\mathrm{k}_{1}$ otimizado $=0,89 \mathrm{~h}^{-1}(\mathrm{~F}=1564)$ \\
\hline
\end{tabular}

Nota: $t$ corresponde ao tempo em horas

Pela Tabela 40 é possível observar que os valores obtidos para a constante cinética aparente de $1^{\mathrm{a}}$ ordem resultaram de aproximadamente $0,79 \mathrm{~h}^{-1}$ para o perfil 1 
e de $0,89 \mathrm{~h}^{-1}$ para o perfil 2, ou seja, com a aplicação da vazão de recirculação houve aumento de aproximadamente $13 \%$ do valor de $\mathrm{k}_{1}$. O aumento do valor de $\mathrm{k}_{1}$ no perfil 2 pode estar relacionado à expansão do leito da biomassa microbiana que melhora a transferência de massa. $\mathrm{O}$ aumento do tempo de retenção celular de $44 \mathrm{~d}$ para 144 d e da comunidade microbiana do Domínio Archaea e do Domínio Bacteria, verificados por Passig (2005), também podem ter contribuído para o acréscimo do valor da constante cinética aparente de $1^{\mathrm{a}}$ ordem.

A Figura 37 apresenta os resultados observados por Passig (2005) e calculados pelo MMS da variação da DQO efluente ao longo do tempo para os perfis 1 e 2 .

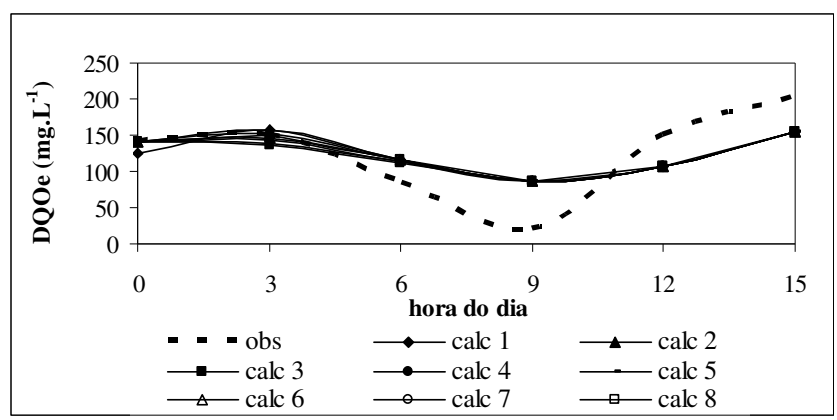

(a)

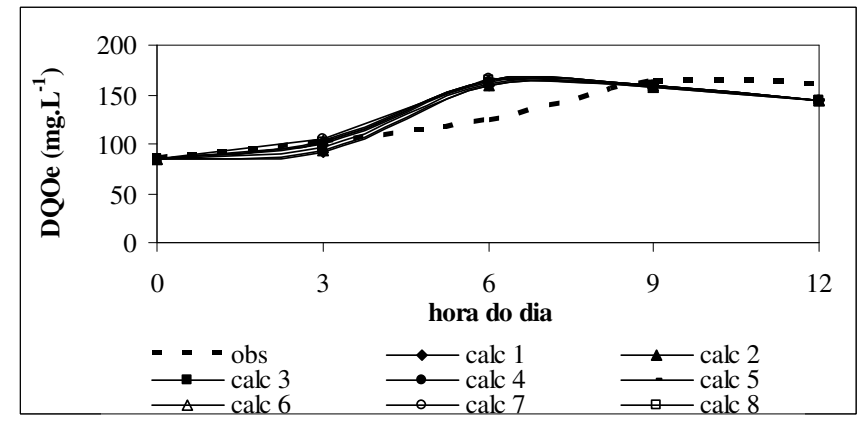

(b)

Figura 37. Resultados da variação de DQO efluente ao longo do tempo observados e calculados nos perfis de $24 \mathrm{~h}$ de amostragem temporal do reator: a) perfil $1\left(\mathrm{TDH}=6 \mathrm{~h}\right.$; Vasc $\left.=0,78 \mathrm{~m} \cdot \mathrm{h}^{-1}\right)$; b) perfil $2(\mathrm{TDH}=6 \mathrm{~h}$, Vasc $=$ $\left.1,71 \mathrm{~m} \cdot \mathrm{h}^{-1}, \mathrm{qr}=50 \% \mathrm{Q}\right)$

Ao comparar os resultados observados e calculados de DQO efluente para o perfil 1, é possível verificar variação de 20 a $203 \mathrm{mg} . \mathrm{L}^{-1}$ e de 86 a $158 \mathrm{mg} . \mathrm{L}^{-1}$, respectivamente. No perfil 2, os resultados observados variaram de 85 a $163 \mathrm{mg} . \mathrm{L}^{-1} \mathrm{e}$ 
os calculados variaram de 85 a $166 \mathrm{mg} . \mathrm{L}^{-1}$. É possível notar menor amplitude dos valores de DQO efluente na recirculação de 50\% da vazão média afluente (Figura 37 a., Figura 37 c.), com diferença de aproximadamente $60 \%$ e $4 \%$ para os perfis 1 e 2, respectivamente, entre os valores calculados e observados (Tabela 41).

Os resultados obtidos nas simulações corroboram as observações reportadas por Passig (2005), pois o autor destaca melhor resposta do reator na eficiência de remoção de DQO, DBO e de SST de aproximadamente 81\%, 91\% e 79\%, respectivamente, com aumento da velocidade ascensional para $1,17 \mathrm{~m} \cdot \mathrm{h}^{-1}$.

A Tabela 41 apresenta o conjunto de dados de DQO efluente observado por Passig (2005) e calculado pelo modelo MMS.

Tabela 41. Resumo do conjunto de valores de DQO efluente observado e calculado) ao longo do tempo nos perfis 1 e 2

\begin{tabular}{|c|c|c|c|c|}
\hline perfil & \multicolumn{2}{|c|}{1} & \multicolumn{2}{|r|}{2} \\
\hline $\begin{array}{c}\mathbf{t} \\
(\mathbf{h})\end{array}$ & $\begin{array}{l}\text { DQOobs } \\
\left(\mathrm{mg}^{-L^{-1}}\right)\end{array}$ & $\begin{array}{c}\text { DQO calc } \\
\left(\mathrm{mg.L}^{-1}\right)\end{array}$ & $\begin{array}{c}\text { DQOobs } \\
\left(\mathrm{mg.L}^{-1}\right)\end{array}$ & $\begin{array}{c}\text { DQO calc } \\
\left(\mathrm{mg.L}^{-1}\right)\end{array}$ \\
\hline 0 & 142 & 142 & 85 & 85 \\
\hline 3 & 151 & 137 a 158 & 102 & 93 a 105 \\
\hline 6 & 84 & 112 a 116 & 124 & 160 a 166 \\
\hline 9 & 20 & 86 a 87 & 163 & 158 a 160 \\
\hline 12 & 149 & 107 & 161 & 143 a 144 \\
\hline 15 & 203 & 154 a 155 & - & - \\
\hline
\end{tabular}




\section{CONCLUSÕES E SUGESTÕES}

Com base nos resultados obtidos por ensaios, análises e determinações realizadas ao longo do período de operação do reator UASB pode ser concluído que:

Pelos resultados obtidos na etapa I de operação do reator UASB de 146 L com vazão média afluente constante $\left(18,2\right.$ L.h $\left.{ }^{-1}\right)$ e orgânica variável $(0,16$ a 0,42 kgDQO. $\mathrm{d}^{-1}$ ) durante 291 dias, concluiu-se que após o reator ter atingido o estado de equilíbrio dinâmico aparente $\left(90^{\circ}\right.$ dia de operação) a eficiência de remoção de DQO bruta variou de $48 \%$ a $81 \%$ e de DBO variou de $69 \%$ a $85 \%$. A concentração de ácidos voláteis no efluente resultou inferior a $78 \mathrm{mgHAc} . \mathrm{L}^{-1}$; $\mathrm{pH}$ variável de 6,2 a 7,0 no afluente e de 6,9 a 7,3 no efluente e alcalinidade do efluente superior ao do afluente, o que indicou a capacidade do sistema de tamponamento do meio.

A eficiência de remoção de DQO foi prejudicada nessa etapa de operação devido à elevada concentração de sólidos no efluente do reator. O arraste de sólidos no efluente ocorreu provavelmente pela formação de "bolsões de biogás" que carreavam os sólidos para a saída do reator.

Com a substituição do separador de fases na etapa II, os resultados da operação do reator UASB de $160 \mathrm{~L}$ com vazão média afluente constante $\left(16{\left.\mathrm{~L} . \mathrm{h}^{-1}\right) \mathrm{e}}^{-1}\right.$ orgânica variável $\left(0,22\right.$ a $\left.0,35 \mathrm{kgDQO} . \mathrm{d}^{-1}\right)$ durante 198 dias indicaram que a eficiência de remoção de DQO bruta variou de $46 \%$ a 61\%, após o reator ter atingido o estado de equilíbrio dinâmico aparente ( $303^{\circ}$ dia de operação).

A concentração de ácidos voláteis no efluente resultou inferior a 54 mgHAc. $\mathrm{L}^{-1}$; pH variável de 6,2 a 6,4 no afluente e de 6,8 a 7,1 no efluente e alcalinidade do efluente superior ao do afluente, o que indicou a capacidade do sistema de tamponamento do meio. Houve geração de ácidos voláteis no afluente, 
provavelmente devido à prévia degradação do substrato nos tanques de alimentação do sistema.

Nessa etapa também foi verificado arraste de sólidos no efluente do reator, provavelmente devido ao menor volume de substrato presente nos tanques de armazenamento e a maior concentração de sólidos depositada no fundo dos tanques de armazenamento.

A variabilidade da concentração de matéria orgânica do afluente não influenciou a estabilidade do reator nas etapas $I$ e $I I$, uma vez não foi verificado aumento da concentração da matéria orgânica no efluente.

Na etapa III, com a aplicação da variação senoidal cíclica da vazão afluente de 16,0 L.h ${ }^{-1}$ em valores superiores e inferiores a $40 \%$ no reator UASB de $160 \mathrm{~L}$ durante 34 dias, verificou-se que a eficiência de remoção de DQO bruta variou de $32 \%$ a $48 \%$, após o reator ter atingido o estado de equilíbrio dinâmico aparente $\left(319^{\circ}\right.$ dia de operação). A eficiência de remoção de DQO bruta diminuiu aproximadamente $13 \%$ com aplicação da variação senoidal cíclica de $40 \%$, porém o reator apresentou capacidade de recuperação na remoção de matéria orgânica no período em que a vazão afluente foi reduzida para valor mínimo de $14,5 \mathrm{~L} \cdot \mathrm{h}^{-1}$.

A concentração de ácidos voláteis no efluente resultou inferior a 86 mgHAc. $\mathrm{L}^{-1}$, porém com alguns picos no efluente $\left(131 \mathrm{mgHAc} . \mathrm{L}^{-1}\right)$ e o $\mathrm{pH}$ variou de 6,3 a 6,6 no afluente e de 6,9 a 7,2 no efluente.

Na etapa $I V$, com a aplicação da variação senoidal cíclica em valores superiores e inferiores a $60 \%$ da vazão afluente de $16,0{\mathrm{~L} . \mathrm{h}^{-1}}^{-1}$ no reator UASB de 160 L durante 27 dias, concluiu-se que a eficiência de remoção de DQO bruta variou de $10 \%$ a $59 \%$, após o reator ter atingido o estado de equilíbrio dinâmico aparente ( $348^{\circ}$ dia de operação).

Nos períodos em que houve diminuição da vazão de 18,3 L.h ${ }^{-1}$ para 16,0 L.h ${ }^{-1}$, a eficiência de remoção de DQO bruta diminuiu em aproximadamente $32 \%$, provavelmente devido ao arraste de sólidos que ocorreram nesse período.

O reator apresentou capacidade de recuperação na remoção de matéria orgânica nos períodos com redução da vazão de 16,0 L.h ${ }^{-1}$ para 14,4 L.h ${ }^{-1}$, pois foi 
verificado aumento da eficiência de remoção de DQO bruta em torno de $18 \%$. Porém quando a vazão afluente atingiu o mínimo de 13,7 L.h ${ }^{-1}$, houve diminuição da eficiência de remoção de matéria orgânica em aproximadamente $10 \%$.

Após esse período, com aumento da vazão de 16,0 L.h ${ }^{-1}$ para 18,3 L.h ${ }^{-1}$ (máxima), a eficiência de remoção de matéria orgânica diminuiu em torno de 13\%, provavelmente devido ao arraste de sólidos no efluente do reator.

A concentração de ácidos voláteis no efluente resultou inferior a $70 \mathrm{mgHAc} . \mathrm{L}^{-1}$, porém com alguns picos no efluente $\left(131 \mathrm{mgHAc} . \mathrm{L}^{-1}\right)$ e o $\mathrm{pH}$ variou de 6,1 a 6,7 no afluente e de 6,6 a 7,0 no efluente.

Mesmo com a aplicação da variação senoidal cíclica da vazão afluente e com alguns picos na concentração de ácidos voláteis no afluente e no efluente, o reator apresentou capacidade de tamponamento do meio que foi verificada pelos valores da alcalinidade do efluente superiores aos do afluente nas etapas III e $I V$.

A eficiência do sistema foi prejudicada pelo arraste de sólidos no efluente, provavelmente pela formação dos bolsões devido ao acúmulo de biogás no manto de lodo. A eficiência de remoção de SST e de SSV diminuiu aproximadamente $31 \%$ e $36 \%$ com aplicação das variações senoidais de $40 \%$ e de $60 \%$, respectivamente. Foi possível observar também que nos períodos de aplicação das variações senoidais, o aumento da velocidade ascensional pode ter contribuído para o maior arraste de sólidos.

A produção de gás metano foi de aproximadamente $1,83 \mathrm{~L} \cdot \mathrm{h}^{-1}, 2,24 \mathrm{~L} \cdot \mathrm{h}^{-1}$ e de 2,97 L.h ${ }^{-1}$ para o reator operado com vazão média afluente constante de $16 \mathrm{~L}^{-\mathrm{h}^{-1}} \mathrm{e}$ submetido a variação cíclica de $40 \%$ e de $60 \%$ da vazão afluente, respectivamente.

Os exames microbiológicos realizados em toda a operação do reator identificaram grande diversidade de morfologias presentes no lodo: arquéias metanogênicas semelhantes aos gêneros Metanosarcina sp. e Methanosaeta sp., bacilos, bacilos com incrustrações, bacilos fluorescentes, filamentos, cocos e vibrios semelhantes a bactérias redutoras de sulfato, aglomerados de $\operatorname{cocos}$ e bacilos e espirilos. 
Os resultados obtidos da atividade metanogênica para as condições operacionais de vazão constante e igual a $16,0 \mathrm{~L} \mathrm{~h}^{-1}$ e com aplicação de variação senoidal da vazão afluente de $40 \%$ foram iguais a $0,1555 \mathrm{mmolCH}_{4} \mathrm{~g}^{-1} \mathrm{SV} \mathrm{h}^{-1} \mathrm{e}$ 0,0817 $\mathrm{mmolCH}_{4} \mathrm{~g}^{-1} \mathrm{SV} \mathrm{h}{ }^{-1}$, respectivamente. Para a $3^{\mathrm{a}}$ etapa do experimento, com aplicação da variação senoidal da vazão média afluente em $60 \%$, não foi observada atividade metanogênica dos microrganismos possivelmente devido ao arraste de sólidos causado pelo aumento da velocidade ascensional de operação do reator.

Aparentemente as variações cíclicas senoidais não interferiram na atividade microbiana como um todo, uma vez que o desempenho do reator apresentou resultados semelhantes para remoção de matéria orgânica em termos de DQO bruta e filtrada.

A análise da estrutura microbiana pela técnica do DGGE mostrou que não houve variação na estrutura da comunidade de arquéias nas três condições operacionais, com exceção do ponto 3 do reator que não apresentou bandas no gel para as amostras das vazões com variação senoidal da vazão afluente de $40 \%$ e de $60 \%$.

O perfil de bandas no DGGE com primers para o Domínio Bacteria mostrou diferença entre as populações bacterianas encontradas no ponto 1 em relação àquelas observadas nos pontos 2 e 3. Além disso, a aplicação das vazões senoidais da vazão afluente causou a diminuição da intensidade das bandas e o desaparecimento das mesmas em algumas situações (ponto 3).

A partir dos ensaios hidrodinâmicos foi possível concluir que o reator UASB apresentou comportamento próximo ao reator de mistura completa, comparado à aproximadamente 4 ou 5 reatores N-CSTR em série, para o ensaio sem variação de vazão afluente. Com o aumento da amplitude da variação da vazão afluente constatou-se que o comportamento do reator se aproximou do escoamento de fluxo pistonado. 
Apesar da aplicação das variações senoidais cíclicas de $40 \%$ e $60 \%$, os parâmetros tempo de detenção hidráulica e grau de mistura do reator não apresentaram diferenças significativas quando comparados àqueles parâmetros obtidos para vazão média afluente constante.

Ao comparar o tempo de detenção hidráulico teórico com o calculado pelas curvas de DTR obtidas experimentalmente, verificou-se atraso de aproximadamente $50 \%$ da resposta do traçador para todas as condições operacionais, que poderia indicar existência de zonas mortas hidrodinâmicas no interior do reator. O fenômeno de cauda observado nas curvas obtidas resultou da difusão do traçador nessas zonas mortas e de sua lenta liberação.

Com base nos resultados obtidos nas simulações do modelo ADM1 foi possível concluir que:

Os parâmetros cinéticos k_dis (desintegração do composto particulado), k_hyd_ch (desintegração de carboidratos), k_hyd_pr (desintegração de proteínas) e k_hyd_li (desintegração de lipídeos) iguais a $0,24 \mathrm{~h}^{-1}, 0,79 \mathrm{~h}^{-1}, 0,2 \mathrm{~h}^{-1}$ e $1,75 \mathrm{~h}^{-1}$ representaram o conjunto de parâmetros otimizados que indicou melhor similaridade entre os resultados simulados e os observados para DQO efluente, $\mathrm{pH}$, concentração de ácidos voláteis e alcalinidade a bicarbonato.

As melhores respostas do modelo em relação a DQO efluente foram obtidas para tempos de retenção celular de 50 d e de 100 d, com diferença de $8 \%$ e $12 \%$ entre os valores de DQO efluente observados e calculados. Para $\theta \mathrm{c}$ igual a TDH de $0,4 \mathrm{~d}$, a DQO efluente calculada apresentou diferença de aproximadamente $79 \%$ entre os valores observados e calculados.

Como o modelo ADM1 considera apenas a média aritmética dos valores dos parâmetros de entrada e saída, houve dificuldade para implementação dos resultados experimentais na matriz de equações de taxa e comparação entre os resultados observados e os simulados pelo modelo devido à variabilidade horária e diária de alguns parâmetros. 
Foi possível verificar que a maior similaridade entre os resultados experimentais e os simulados de $\mathrm{pH}$ no efluente ocorreu para $\theta \mathrm{c}$ igual a $100 \mathrm{~d}$ e que houve pequena diminuição dos valores de $\mathrm{pH}$ com o aumento do tempo de retenção celular de $50 \mathrm{~d}$ para $100 \mathrm{~d}$.

Em relação à concentração de ácidos voláteis no efluente, os resultados calculados pelo modelo foram ligeiramente superiores à média dos valores observados experimentalmente. $\mathrm{O}$ modelo indicou a capacidade de tamponamento do reator mesmo com o aumento da concentração de ácidos voláteis no efluente e a queda no $\mathrm{pH}$ quando foi aplicado $\theta \mathrm{c}$ de $100 \mathrm{~d}$.

Ao contemplar o termo referente ao tempo de retenção celular igual a $50 \mathrm{~d}$ e 100 d no AMD1, foi possível obter resultados de produção gasosa de aproximadamente $0,5 \mathrm{~L} \cdot \mathrm{h}^{-1}$. Por outro lado, o valor obtido de $0,1 \mathrm{~L} \cdot \mathrm{h}^{-1}$ para $\theta \mathrm{c}$ igual a 0,4 d resultou da baixa concentração de biomassa presente no interior do reator para que ocorresse a digestão anaeróbia. Esse comportamento foi verificado por valores nulos ou negativos das variáveis de estado dos compostos particulados obtidos nas simulações.

Em todas as simulações, independentemente do valor do tempo de retenção celular adotado, a concentração de biomassa ativa variou de $6910 \mathrm{mgDQO} . \mathrm{L}^{-1}$ a $9600 \mathrm{mgDQO} . \mathrm{L}^{-1}$ no efluente do reator.

O modelo ADM1 apresenta obstáculos na sua implementação por considerar: base de variáveis diferente da usualmente medida experimentalmente para monitoramento do sistema; fracionamento da matéria orgânica que não corresponde ao observado experimentalmente para esgotos de origem doméstica; quantidade significativa de parâmetros a ser determinada experimentalmente nas frações solúvel e particulada para aplicação na matriz de equações.

Com base nos resultados obtidos nas simulações do modelo $M M S$ foi possível concluir que:

Os valores obtidos para a constante cinética aparente de $1^{\mathrm{a}}$ ordem $\left(\mathrm{k}_{1}\right)$ resultaram de aproximadamente $0,61 \mathrm{~h}^{-1}$ a $0,63 \mathrm{~h}^{-1}$ nos perfis de 1 a 4 quando o reator

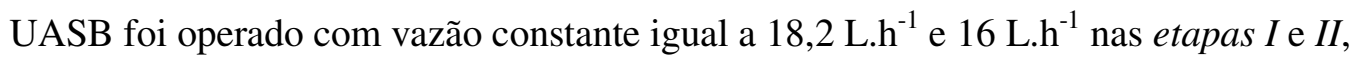
respectivamente. $\mathrm{O}$ arraste de sólidos mais evidente em alguns perfis (2 e 3) não 
influenciou nos valores de $\mathrm{k}_{1}$ obtidos pela otimização da função de minimização $F$. Os valores de $\mathrm{k}_{1}$ diminuíram em aproximadamente $15 \%$ e $64 \%$ quando o reator foi submetido a variações da vazão afluente de $40 \%$ e $60 \%$, respectivamente, resultando em valores iguais a $0,52 \mathrm{~h}^{-1}$ e $0,22 \mathrm{~h}^{-1}$. Provavelmente maiores velocidades de fluxo tenham prejudicado o contato entre os microrganismos e o substrato.

O modelo indicou faixa de valores para DQO efluente de 162 a 229 mg.L $\mathrm{L}^{-1}$ para perfil $1 ; 148$ a $398 \mathrm{mg} . \mathrm{L}^{-1}$ para perfil $2 ; 214$ a $311 \mathrm{mg} . \mathrm{L}^{-1}$ para perfil 3 e $232 \mathrm{a}$ $409 \mathrm{mg} . \mathrm{L}^{-1}$ para perfil 4. As faixas de valores obtidas nas simulações resultaram em diferenças com os resultados observados experimentalmente de aproximadamente: $17 \%$ e $48 \%$ para os perfis 1 e 2 com vazão média afluente constante de 18,2 L.h ${ }^{-1}$; $37 \%$ e $8 \%$ para os perfis 3 e 4 com vazão afluente constante de 16,0 L.h ${ }^{-1}$.

Para as simulações com variações senoidais cíclicas de vazão de $40 \%$ e 60\%, os valores de DQO efluente variaram de 342 a $456 \mathrm{mg} . \mathrm{L}^{-1}$ para perfil 6 e de 204 a $452 \mathrm{mg} . \mathrm{L}^{-1}$ para perfil 8 , ou seja, diferenças de aproximadamente $59 \%$ e $56 \%$, respectivamente. As maiores diferenças obtidas em relação aos valores da DQO efluente (observada e calculada) resultaram da limitação do modelo em considerar o arraste de sólidos no efluente que ocorreu ao longo de toda a operação do reator e mais acentuadamente quando foram aplicadas variações na vazão afluente.

Apesar de considerar a equação da variação da DQO afluente ao longo do tempo, o modelo não consegue representar a variabilidade da DQO afluente ao longo do tempo.

Ao simular os dados reportados por Passig (2005), o MMS indicou valor de $\mathrm{k}_{1}$ de aproximadamente $0,79 \mathrm{~h}^{-1}$ para reator operado com velocidade ascensional constante de $0,78 \mathrm{~m} \cdot \mathrm{h}^{-1}$. Nas simulações com aplicação da vazão de recirculação de $50 \%$ da vazão média afluente, houve aumento de aproximadamente $13 \%$ do valor de $\mathrm{k}_{1}$ que resultou em aproximadamente $0,89 \mathrm{~h}^{-1}$, provavelmente devido ao maior contato entre a biomassa e o substrato que intensificou a transferência de massa.

Os resultados obtidos nas simulações para variação da DQO efluente ao longo do tempo dos perfis 1 e 2 indicaram diferenças de aproximadamente $60 \%$ e 3\%, respectivamente, em relação aos resultados observados por Passig (2005). A menor amplitude da variação da DQO efluente ao longo do tempo pode ser corroborada experimentalmente pela melhor eficiência do reator na remoção de 
DQO, DBO e de SST com o aumento da velocidade ascensional para $1,17 \mathrm{~m} \cdot \mathrm{h}^{-1}$, conforme reportado por Passig (2005).

Diante dos resultados e conclusões obtidos, sugere-se para trabalhos futuros:

○ Avaliação da resposta dinâmica de reatores UASB, em escala real tratando esgotos domésticos, submetidos a variações de cargas senoidais cíclicas da vazão afluente em valores inferiores e superiores a 40\%, 60\% e $80 \%$;

○ Avaliação do comportamento hidrodinâmico do reator UASB de $160 \mathrm{~L}$ com cloreto de lítio como traçador quando operado com vazão média afluente constante de $16 \mathrm{~L} \cdot \mathrm{h}^{-1}$ e submetido a variações senoidais cíclicas da vazão afluente em valores inferiores e superiores a $40 \%$ e $60 \%$;

○ Implementação de matriz de valores no modelo ADM1 com variação diária e horária de alguns parâmetros, como por exemplo, DQO afluente;

○ Implementação de matriz que contemple variações de cargas orgânicas e hidráulicas no modelo ADM1;

○ Implementação de parâmetros de inibição e de decaimento celular no modelo MMS;

○ Implementação de regime hidrodinâmico de fluxo pistonado no modelo MMS para reator UASB sem recirculação e com recirculação de vazão;

○ Implementação do modelo MMS como reator de fluxo laminar. 


\section{REFERÊNCIAS BIBLIOGRÁFICAS}

ANDRADE, S.G.; SILVEIRA, B.F., OLIVEIRA, R.N. (2001). Recentes avanços em processos de fermentação alcoólica. Revista Brasileira de Fermentação Alcoólica, v.14, n. 2, p. 326-333.

AISSE, M.M. et al. (2000) Avaliação do sistema reator UASB e filtro biológico para o tratamento de esgoto sanitário. IN: XXVII CONGRESSO INTERAMERICANO DE ENGENHARIA SANITÁRIA E AMBIENTAL, 2000, Porto Alegre, Brasil, v.1, p 1-9.

AIYUK, S.; FORSTER, I.; LIEVEN, D.K.; VAN HAANDEL, A.; VERSTRAETE, W. (2006). Anaerobic and complementary treatment of domestic sewage in regions with hot climates - a review. Bioresource Technology, v.97, n.17, p.2225-2241, novembro.

BARBOSA, R.A.; SANT'ANNA JR., G.L. (1989). Treatment of raw domestic sewage in an UASB reactor. Water Research, v.23, n.12, p. 1483-1489, dezembro.

BATISTA, K.B. (2000). Resposta dinâmica dos reatores UASB (Upflow Anaerobic Sludge Blanket) submetidos a cargas senoidais. São Carlos. 132p. Dissertação (Mestrado) - Escola de Engenharia de São Carlos, Universidade de São Paulo.

BATSTONE, D., KELLER, J., NEWELL, B., NEWLAND, M. (1997). Model development and full-scale validation for anaerobic treatment of protein and fat based wastewater. Water Science Technology, v.36, n.6-7, p.423-431.

BATSTONE, D. (2000). High-rate anaerobic treatment of complex wastewater. PhD Thesis, University of Queensland, Brisbane. 
BATSTONE, D.J., KELlER, J., NEWELL, R.B., NEWLAND, M. (2000). Modelling anaerobic degradation of complex wastewater. I: Model development. Bioresource Technology, v.75, n.1, p.67-74, outubro.

BATSTONE, D. et al. (2002a). Anaerobic Digestion Model no 1. IWA Publishing, London. p.77.

BATSTONE, D. et al. (2002b). The IWA anaerobic digestion model no 1 (ADM1). Water Science Technology, v.45, n.10, p.65-73.

BATSTONE, D.J.; KELLER, J. (2003). Industrial applications of the IWA anaerobic digestion model No. 1 (ADM1). Water Science and Technology, v. 47, n.12, p. 199-206.

BEHLING, E. et al. (1997). Domestic wastewater treatment using a UASB reactor. Bioresource Technology, v.61, n.61, p.239-245, novembro.

BERNARD, O., CHACHUAT, B., HÉliAS, A., RODRIGUEZ, J. (2006). Can we assess the model complexity for a bioprocess: theory and example of the anaerobic digestion process. Water Science and Technology, v.53, n.1, p.85-92.

BOLLE, W. L. et al. (1986). An integral dynamic model for the UASB reactor. Biotechnology and Bioengineering, v.28, n.11, p.1621-1636, novembro.

BORJA, R., BANKS, J.C. (1995). Response of an anaerobic fluidized bed reactor treating ice-cream wastewater to organic, hydraulic, temperature and $\mathrm{pH}$ shocks. Journal of Biotechnology, v.39, n.3, p.251-259, maio.

BREURE, et al. (1986). Acidogenic fermentation of protein carbohydrate mixtures by bacterial populations adapted to one of the substances in anaerobic chemostat cultures. Appl. Microbiol. Biotechnol. v. 23, n.3-4, p. 245-249, janeiro.

BRITO, A.G.; MELO, L.F. (1997). A simplified analysis of reaction and mass transfer in UASB and EGSB reactors. Environmental Technology, v.18, p.3544, setembro.

BRITO, A.G., MELO, L.F. (1999). Mass transfer coefficients within anaerobic biofilms: effects of external liquid velocity. Water Research, v. 33, n.17, p.3673-3678, dezembro. 
BRUCHA, G. (2002). Avaliação da diversidade microbiana de consórcios anaeróbios enriquecidos a partir de amostras de sedimento lacustre na degradação anaeróbia do tricloroetileno/TCE, empregando-se a técnica de Eletroforese em Gel com Gradiente Desnaturante/DGGE. São Carlos. 150p. Dissertação (Mestrado) - Escola de Engenharia de São Carlos, Universidade de São Paulo.

BUTLER, D., FRIEDLER, E., GATT, K. (1995). Characterizing the quantity and quality of domestic wastewater inflows. Water Science and Technology, v.31, n.7, p.13-24.

CABRAL, A.K.A. (2000). Avaliação do desempenho e estabilidade de um reator anaeróbio horizontal de leito fixo (RAHLF) submetido ao aumento progressivo na concentração de matéria orgânica afluente e a cargas de choque orgânicas. São Carlos. 92p. Tese (Doutorado) - Escola de Engenharia de São Carlos, Universidade de São Paulo.

CAMPOS, H.M, VON SPERLING, M. (1996). Estimation of domestic wastewater characteristics in a developing country based on socio-economic variables. Water Science and Technology, v.34, n.3/4, p.71-77.

CARVALHO, K.Q. (2002). Resposta dinâmica dos reatores UASB (Upflow Anaerobic Sludge Blanket) submetidos a cargas orgânicas e hidráulicas cíclicas - modelação matemática. São Carlos. 104p. Dissertação (Mestrado) Escola de Engenharia de São Carlos, Universidade de São Paulo.

CARVALHO, K.Q; PIRES, E.C. (2002). Dynamic response of UASB reactors submitted to diurnal cyclical flow: simplified mathematical model. In: VII LATIN AMERICAN WORKSHOP AND SYMPOSIUM ON ANAEROBIC DIGESTION, 2002, Mérida, México, v.1, p 189-196.

CASTILLO, A., CECCHI, F., MATA-ALVAREZ, J. (1997). A combined anaerobicaerobic system to treat domestic sewage in coastal areas. Water Science and Technology, v.31, n.12, p.3057-3063.

CASTILlO, A.; LLABRES, P.; MATA-ALVAREZ, J. (1999). A kinetic study of a combined anaerobic-aerobic system for treatment of domestic sewage. Water Research, v.33, n.7, p.1742-1747, setembro. 
CHAVÉZ, C.P.; CASTILLO, R.L.; DENDOOVEN, L.; ESCAMILLA-SILVA, E.M. (2005). Poultry slaughter wastewater treatment with an up-flow anaerobic sludge blanket (UASB) reactor. Bioresource Technology, v.96, n.1, p.17301736, junho.

CHEN, S.D. et al. (1996). Treatment of high-nitrate wastewater by biological methods - operational characteristics study. Water Science and Technology, v.34, n.1/2, p.269-276.

CHERNICHARO, C.A.L. (1997). Princípios do tratamento biológico de águas residuárias: Reatores anaeróbios. 1.ed. Belo Horizonte, DESA/ UFMG. cap5., p.156.

CHERNICHARO, C.A.L., CARDOSO, M.R. (1999). Development and evaluation of a partitioned upflow anaerobic sludge blanket (UASB) reactor for the treatment of domestic sewage from small villages. Water Science and Technology, v.40, n.8, p.107-113.

CHUA, H. et al. (1997). Responses of anaerobic fixed-film reactor to hydraulic shock loadings. Bioresource Technology, v.61, n.1, p.79-83, março.

COPP, JB.; BELIA, E.; SNOWLING, S.; SCHRAA, O. (2005). Anaerobic digestion: a new model for plant-wide wastewater treatment process modeling. Water Science and Technology, v. 52, n.10-11, p. 1-11.

COSTELLO, D.J., GREENFIELD, P.F., LEE, P.L. (1991). Dynamic modeling of a single-stage high rate anaerobic reactor: 2. model prediction. Water Research, v.25, n.7, p.859-871, julho.

DALTRO FILHO, J. (1988). Desempenho de filtros anaeróbios no tratamento de esgotos sanitários: efeitos da altura do filtro e de toxicidade por cobre. Tese (Doutorado) - Escola de Engenharia de São Carlos, Universidade de São Paulo, São Carlos. 1988.

DE GRACIA, M., SANCHO, L., GARCÍA-HERAS, J.L., VANROLLEGHEM, P., AYESA, E. (2006). Mass and charge conservation check in dynamic models: application to the new ADM1 model. Water Science and Technology, v.53, n. 1, p. 225-240. 
DE NARDI, IR; ZAIAT, M; FORESTI, E. (1999). Influence of the tracer characteristics on hydrodynamic models of packed-bed bioreactors. Bioprocess Engineering, v. 21, n.5, p. 469-476, novembro.

DOCHAIN, D.E., VANROLlEGHEM, P.A. (2001). Dynamical Modelling and Estimation in Wastewater Treatment Processes. IWA Publishing, London.

EDGEHILL, R.U. (1998). Mathematical analysis of trickling filter response to pentachlorophenol shock load. Biochemical Engineering Journal, v.3, n.1, p.55-60, dezembro.

EL-FARHAN, M. H.; SHIEH, W. K. (1999). Overloading responses of a glucosedfed anaerobic fluidized bed reactor. Biochemical Engineering Journal, v.3, n.1, p.17-23, fevereiro.

FLORENCIO, L.; KATO, M.T.; DE MORAIS, J.C. (2001). Domestic sewage treatment in full-scale UASBB plant at Mangueira, Recife, Pernambuco. Water Science Technology, v.44, n.4, p.71-77.

FORESTI, E. et al. (1999). Fundamentos do tratamento anaeróbio. In: CAMPOS, J.R., coord. Tratamento de esgotos sanitários por processo anaeróbio e disposição controlada no solo. Rio de Janeiro, ABES/ Projeto PROSAB. Cap2., p.29-52.

FORESTI, E. (2002). Anaerobic treatment of domestic sewage: established technologies and perspectives. Water Science and Technology, v.45, n.10, p.181-186.

FRANCO, A.; ROCA, E.; LEMA, J. M. (2002a). Improvement of the properties of granular sludge in UASB reactors, by flow pulsation. In: VII WORKSHOP AND SYMPOSIUM ON ANAEROBIC DIGESTION, 2002, Mérida, México, Anais, v.1, p 237-244.

FRANCO, A.; GRESIA, G.; ROCA, E.; ROZZI, A.; LEMA, J. M. (2002b). Influence of pulsation on start-up of UASB reactors. Water Science and Technology, v. 45, n. 10, p. 163-168.

GAVALA, H. N.; KOPSINIS, H.; SKIADAS, I. V.; STAMATELATOU, K.; LYBERATOS, G. (1999). Treatment of dairy wastewater using an upflow anaerobic sludge blanket reactor. Journal of Agricultural Engineering Research, v. 73, n.1, p. 59-63, maio. 
GERNAEY, K.V., ROSEN, C., BATSTONE, D.J., ALEX, J. (2006). Efficient modeling necessitates standards for model documentation and exchange. Water Science and Technology, v. 53, n. 1, p. 277-285.

GIMENEZ, J.R. et al. (2001). Physical modeling of an upflow anaerobic sludge blanket reactor: near field study. In: CONGRESS ON ANAEROBIC DIGESTION, 9, Belgium, 2-6/setembro, Proceedings. Antwerp, Technologisch Instituut vzw. p.693-698.

HALALSHEH, M.M. (2002). Anaerobic pre-treatment of strong sewage: a proper solution for Jordan. Wageningen. 113p. Ph.D. Thesis. Wageningen University, The Netherlands.

HAMODA, M. F.; AL-SHAREKH, H. A. (1999). Sugar wastewater treatment with aerated fixed-film biological systems. Water Science and Technology, v.40, n.1, p.313-321.

HANAI, F.Y. (1997). Caracterização qualitativa e quantitativa de esgotos sanitários. São Carlos. 235p. Dissertação (Mestrado) - Escola de Engenharia de São Carlos, Universidade de São Paulo.

HIRASAWA, J. S. (2003). Avaliação da comunidade microbiana anaeróbia em reator sulfetogênico utilizando a hibridação in situ com sondas fluorescentes (FISH). São Carlos. 82p. Dissertação (Mestrado) - Escola de Engenharia de São Carlos, Universidade de São Paulo.

INSTITUTO BRASILEIRO DE GEOGRAFIA E ESTATISTICA (2002) - Pesquisa nacional de saneamento básico, Rio de Janeiro, 397p.

JIMÉNEZ, B; NOYOLA, A; CAPDEVILLE, B. (1988). Selected dyes for residence time distribution in bioreactors. Biotechnology Techniques, v.2, n.2, p. 77-82.

JIMÉNEZ, B; NOYOLA, A; CAPDEVILLE, B; ROUSTAN, M; FAUP, G. (1988). Dextran blue colorant as a reliable tracer in submerged filters. Water Research, v.23, n. 10, p. 1253-1257, outubro.

KALYUZHNY, S. V. et al. (1996). Organic removal and microbiological features of UASB-reactor under various organic loading rates. Bioresource Technology, v. 55, n.1, p. 47-54, janeiro. 
KUDO, Y.; NAKAJIMA, T.; MIYAKI, T.; OYAIZU, H. (1997). Methanogen flora of paddy soils in Japan. FEMS Microbiology Ecology, v. 22, n.1, p. 39-48, janeiro.

LABIB, F. et al. (1993). Mathematical modeling of an anaerobic butyrate degrading consortia: Predicting their response to organic overloads. Environmental Science Technology, v.27, n. 13, p.2673-2684, dezembro.

LEITÃO, R.C. (2004). Robustness of UASB reactors treating sewage under tropical conditions. (2004) PhD Thesis, Wagenigen University, Wagenigen, Netherlands.

LEITÃO, R.C., SILVA-FILHO, J.A., SANDERS, W., VAN HAANDEL, A.C., ZEEMAN, G., LETTINGA, G. (2005). The effect of operational conditions on the performance of UASB reactors for domestic wastewater treatment. Water Science and Technology, v.52, n.1-2, p.299-305.

LETTINGA, G.; ROERSMA, R.; GRIN, P. (1983). Anaerobic treatment of raw domestic sewage at ambient temperatures using a granular bed UASB reactor. Biotechnology and Bioengineering. v.25, n.7, p.1701-1723, julho.

LETTINGA, G. (1996). Sustainable integrated biological wastewater treatment. Water Science and Technology. v.33, n.3, p.85-98.

LETTINGA, G. (1996). ANAEROBIC WASTEWATER TREATMENT. SEMINÁRIO INTERNACIONAL - TENDÊNCIAS NO TRATAMENTO SIMPLIFICADO DE ÁGUAS RESIDUÁRIAS DOMÉSTICAS E INDUSTRIAIS, Belo Horizonte, Minas Gerais.

LEVENSPIEL, O. (1999) Chemical Reaction Engineering. $3^{\text {rd }}$ edition. New York: John Wiley and Sons.

LEW, B.; TARRE, S.; BELAVSKI, M.; GREEN, M. (2004). UASB reactor for domestic wastewater treatment at low temperatures: a comparison between a classical UASB and Hybrid UASB-filter reactor. Water Science and Technology. v.49, n. 11-12, p.295-301.

LIMA, CAA (2001). Tratamento de esgoto sanitário em reator horizontal de leito fixo (RAHLF) - Escala Piloto. São Carlos, 165p. Tese (doutorado) - Escola de Engenharia de São Carlos, Universidade de São Paulo. 
MAHMOUD, N. et al. (2003). Solids removal in upflow anaerobic reactors, a review. Bioresource Technology, v.90, n.1, p.1-9, outubro.

MARELLI, L.M. (2006). "Desenvolvimento e estudo de um bioreator anaeróbio de filtração, com membrana alternativa, utilizado para o tratamento de águas residuárias”. São Carlos. Tese (Doutorado) - Escola de Engenharia de São Carlos, Universidade de São Paulo. em andamento.

MARSILI-LIBELLI, S.; BENI, S. (1996). Shock load modelling in the anaerobic digestion process. Ecological Modeling, v.84, n.84, p.215-232, junho.

MENDONÇA, N.M. (2004). Tratamento de esgoto sanitário empregando reator de leito expandido em escala plena com zonas anaeróbia e aeróbia sobrepostas: concepção, construção e operação. São Carlos. 264p. Tese (Doutorado) Escola de Engenharia de São Carlos, Universidade de São Paulo.

METCALF \& EDDY, INC. (1991). Wastewater Engineering - treatment, disposal and reuse. 3. ed. Estados Unidos, McGraw-Hill. Cap.2, p.29-46; Cap.3, p.47-119.

MITRA, I.N., SENGUPTA, A.K., KUGELMAN, I.J. (1998). Improving stability of anaerobic biological reactors using composite ion exchangers. Water Science and Technology, v.38, n.8-9, p.369-376.

MORGAN-SAGASTUME, JM; JIMÉNEZ, B; NOYOLA, A. (1997). Tracer studies in a laboratory and pilot scale UASB reactor. Environmental Technology, V. 18, n., p. $817-825$.

MUYZER, G., DEWAAL, E.C., UITTERLINDEN, A.G. (1993). Profiling of complex microbial populations by denaturing gradient gel-electrophoresis analysis of polymerase chain reaction - amplified genes-coding for $16 \mathrm{~S}$ ribosomal-RNA. Applied and Environmental Microbiology, v.59, n.3, p. 695700, março.

NACHAIYASIT S.; STUCKEY, D. C. (1997a). The effect of shock loads on the performance of an anaerobic baffled reactor (ABR). 1. Step changes in feed concentration at constant retention time. Water Research, v. 31, n. 11, p. 2737-2746, novembro. 
NACHAIYASIT S.; STUCKEY, D. C. (1997b). The effect of shock loads on the performance of an anaerobic baffled reactor (ABR). 1. Step and transient hydraulic shocks at constant feed strength. Water Research, v. 31, n. 11, p. 2747-2754, novembro.

NICIURA, C.L. (2005). Avaliação do uso da banda de rodagem de pneus inservíveis triturada como suporte ao desenvolvimento de biofilmes em um reator anaeróbio de leito expansível. São Carlos. 179p. Tese (Doutorado) Escola de Engenharia de São Carlos, Universidade de São Paulo.

NIELSEN, T. A., LIU, W-T., FILIPE, C., GRADY, L., MOLIN, S. AND STAHL, D. A. (1999). Identification of novel group of bacteria in sludge from a deteriorated biological phosphorus removal reactor. Applied and Environmental Microbiology., v. 65, n.3, p. 1251-1258, março.

NOUR, E.A.A. (1996). Tratamento de esgoto saintário empregando-se reator anaeróbio compartimentado. 148p. Tese (Doutorado) - Escola de Engenharia de São Carlos, Universidade de São Paulo, São Carlos. 1996.

OLIVA, L.C.H.V. (1997). Tratamento de esgotos sanitários com reator anaeróbio de manta de lodo (UASB): protótipo - desempenho e respostas dinâmicas às sobrecargas hidráulicas. São Carlos. 218p. Tese (Doutorado) - Escola de Engenharia de São Carlos, Universidade de São Paulo.

OLSSON, G. E NEWELL, B. (1999). Wastewater Treatment Systems: Modelling, Diagnosis and Control. IWA Publishing, London.

ORHON, D. et al. (1997). Characterization and COD fractionation of domestic wastewaters. Environmental Pollution, v.95, n.2, p.191-204, setembro.

PALENZUELA-ROLLON, A. et al. (2001). Treatment of fish processing wastewater in a one or two step upflow anaerobic sludge blanket (UASB) reactor. In: CONGRESS ON ANAEROBIC DIGESTION, 9., Belgium, 2-6/setembro, Proceedings. Antwerp, Technologisch Instituut vzw. p.323-328. 
PASSIG, FH., VILELLA, LH., FERREIRA, OP. (2000). Piracicamirim sewage treatment plant - conception utilizing anaerobic process followed by aerobic process - evaluation of operational conditions and compatibility of the processes. In: VI OFICINA E SEMINÁRIO LATINO-AMERICANO DE DIGESTÃO ANAERÓBIA, Brasil, 2-6/setembro, Proceedings. Recife PE. p.323-328.

PASSIG, F. H. (2005). Reator anaeróbio híbrido para tratamento de esgoto sanitário. São Carlos. 150p. Tese (Doutorado) - Escola de Engenharia de São Carlos, Universidade de São Paulo.

PARKER, W.J (2005). Application of the ADM1 model to advanced anaerobic digestion. Bioresource Technology, v. 96, n.16, p. 1832-1842, novembro.

PAULA JR, D.R. (1992). Toxicidade em reatores de manta de lodo (UASB): efeitos do aumento progressivo na concentração inicial de sulfeto. São Carlos. 235p. Tese (Doutorado) - Escola de Engenharia de São Carlos, Universidade de São Paulo.

PAULA JR., D.R.; FORESTI, E. (1992). Kinetics studies on a UASB reactor subjected to increasing COD concentration. Water Science and Technology, v. 25, p.103-111.

PICIOREANU, C.; BATSTONE, D.J.; VAN LOOSDRECHT, M.C.M. (2005). Multidimensional modelling of anaerobic granules. Water Science and Technology, v. 52, n.1-2, p. 501-507.

PIRES, E. C. et al. (2001). Dynamic behaviour of UASB reactors submited to cyclical loads. In: CONGRESS ON ANAEROBIC DIGESTION, 9, Belgium, 2-6/setembro, Proceedings. Antwerp, Technologisch Instituut VZW. p.219-221.

POVINELLI, S. C. S. (1994). Estudo da hidrodinâmica e partida de reator anaeróbio com chicanas tratando esgoto sanitário. 181p. Dissertação (Mestrado) - Escola de Engenharia de São Carlos, Universidade de São Paulo, São Carlos. 1994.

QUEEN, A.S. (2006). Simulador de Reatores Anaeróbios com base no ADM1. 100p. Dissertação (Mestrado) - Escola Politécnica da Universidade de São Paulo, São Paulo. 2006. 
RAMSAY, I.R. (1997). Modelling and control of high-rate anaerobic wastewater treatment systems. (1997) PhD Thesis, University of Queensland, Brisbane.

RIBEIRO, N. J. et al. (2001). Influence of upflow velocity on the performance of an anaerobic filter under oleic acid overloads. Biotechnology Letters, v. 23, n.2, p. 1833-1839, novembro.

RODRÍGUEZ-MARTÍNEZ, J. et al. (2002). Kinetics of anaerobic treatment of slaughterhouse wastewater in batch and upflow anaerobic sludge blanket reactor. Bioresource Technology, v.85, n.1, p.235-241, junho.

ROMLI, M. et al. (1995). Model prediction and verification of a two-stage high-rate anaerobic wastewater treatment system subjected to shock loads. Process Safety Environmental Protection, v.73, p.151-154.

SANCHEZ, E. et al. (2005). Effect of organic loading rate on the stability, operational parameters and performance of a secondary upflow anaerobic sludge bed reactor treating piggery waste. Bioresource Technology, v. 96, n. 3, p.335-344, fevereiro.

SEGHEZZO, L.; GUERRA, R.G.; GONZÁLES, S.M.; TRUPIANO, A.P.; FIGUEROA, M.E.; CUEVAS, C.M.; ZEEMAN, G.; LETTINGA, G. (2002). Removal efficiency and methanogenic activity profiles in a pilot-scale UASB reactor treating settled sewage at moderate temperatures. Water Science and Technology, v. 45, n.10, p.243-248.

SEGHEZZO, L. (2004). Anaerobic treatment of domestic wastewater in subtropical regions. Wageningen. 172p. Ph.D. Thesis. - sub-department of environmental technology, Wageningen University, The Netherlands.

SHANG, Y.; JOHNSON, B.R.; SIEGER, R. (2005). Application of the IWA Anaerobic Digestion Model (ADM1) for simulating full-scale anaerobic sewage sludge digestion. Water Science and Technology, v. 52, n.1-2, p. 487492.

SKIADAS, I. V.; LYBERATOS, G. (1998) The periodic anaerobic baffled reactor. Water Science and Technology, v. 38, n. 8-9, p. 401-408.

SKIADAS, I. V.; GAVALA, H. N.; LYBERATOS, G. (2000) Modelling of the periodic anaerobic baffled reactor (PABR) based on the retaining factor concept. Water Science and Technology, v. 34, n. 15, p. 3725-3736. 
SOTEMANN, S.W.; VAN RENSBURG,, P.; RISTOW, N.E.; WENTZEL, M.C.; LOEWENTHAL, R.E.; EKAMA, G.A. (2005). Integrated chemical/physical and biological processes modelling Part 2 - Anaerobic digestion of sewage sludges. Water $S A$, v. 31, n.4, p. 545-568, outubro.

SPEECE, R.E. (1996). Anaerobic biotechnology for industrial wastewaters. Nashville, Tennessee. Archae Press.

STAMATELATOU, K; LYBERATOS, G. (2002). Simulation of a periodic anaerobic baffled reactor (PABR): steady state and dynamic response. Water Science and Technology, v. 45, n. 10, p. 81-86.

STAMATELATOU, K.; VAVILIN, V.; LYBERATOS, G. (2003a). Performance of a glucose fed periodic anaerobic baffled reactor (PABR) under increasing organic loading conditions: 1. Experimental results. Bioresource Technology, v. 88, n.2, p. 131-136, junho.

STAMATELATOU, K. et al. (2003b). Performance of a glucose fed periodic anaerobic baffled reactor (PABR) under increasing organic loading conditions: 2. Model prediction. Bioresource Technology, v. 88, p. 137-142, junho.

STANDARD METHODS FOR THE EXAMINATION OF WATER AND WASTEWATER (1998). 20.ed. Amer. Public Health Association/American Water Works Association, Water Environment Federation. Washington, D.C., USA, 1134p.

STEIL, L.; CALIJURI, M.C.; VAZOLLER, R.F. (2004). Specific methanogenic activity test as a tool to microbial characteristics assessment in sewage anaerobic stabilization pond sludge. In: THE FIRST INTERNATIONAL MEETING ON ENVIRONMENTAL BIOTECHNOLOGY AND ENGINEERING, Cidade do México, Proceedings. México. CD

THOMAS, M.V. \& NORDSTEDT, R.A. (1993). Generic anaerobic digestion model for the simulation of various reactor types and substrates. American Society of Agricultural Engineering, v.36, n.2, p.537-544, março/abril.

TOMMASO, G.; RIBEIRO, R.; VARESCHE, M.B.; ZAIAT, M.; FORESTI, E. (2003). Influence of multiple substrates on anaerobic protein degradation in a packed-bed bioreactor. Water Science and Technology, v. 48, n. 6, p. 23-31. 
TORRES, P. (1992). Desempenho de um reator anaeróbio de manta de lodo (UASB) de bancada no tratamento de substrato sintético simulando esgotos sanitários. São Carlos. 185p. Dissertação (Mestrado) - Escola de Engenharia de São Carlos, Universidade de São Paulo.

TORRES, P., FORESTI, E. (2001). Domestic sewage treatment in a pilot system composed of UASB and SBR reactors. Water Science and Technology, v. 44, n. 4, p. 247-253.

VAVILIN, V. A.; LOKSHINA, L. Ya.; RYTOW, S. V. (1995). Modelling hydrogen partial pressure change as a result of competition between the butyric and propionic groups of acidogenic bacteria. Bioresource Technology, v. 54, n.2, p. $171-177$.

VAVILIN, V.A., RYTOV, S.V., LOKSHINA, L.Y. (1996). A description of hydrolisis kinetics in anaerobic degradation of particulate organic matter. Bioresource Technology, v. 56, n.2-3, p. 229-237, junho.

VAVILIN et al. (2000). Description of two-step kinetics in methane formation during psychrophilic $\mathrm{H}_{2} / \mathrm{CO}_{2}$ and mesophilic glucose conversions. Bioresource Technology, v.71, n.2, p. 195-209, janeiro.

VIEIRA, L.G.T.; ZAIAT, M.; FORESTI, E. (1997). Intrinsic Kinetic Parameters of Substrate Utilization by Anaerobic Sludge Along the Horizontal-Flow Anaerobic Immobilized Sludge (HAIS) Reactor. Environmental Technology, v.18, n. 9, p. 953-957, setembro.

VAZOLLER R.F. (1989). Manual técnico do curso de ecologia da digestão anaeróbia. São Paulo, CETESB. p.100-107.

ZAIAT, M.; PASSIG, F.H.; FORESTI, E. (2000). A mathematical model and criteria for designing horizontal-flow anaerobic immobilized biomass reactors for wastewater treatment. Bioresource Technology, v.71, n.3, p. 235-243, fevereiro. 


\section{APÊNDICE}

\subsection{PROCESSOS EXCLUÍDOS DO MODELO ADM1}

Os processos de redução de sulfato e de inibição pela presença de gás sulfídrico não foram contemplados no ADM1 devido à complexidade de incorporar um grupo extra de microrganismos que oxidem o sulfato em formas mais reduzidas (com hidrogênio como fonte de elétrons e dióxido de carbono como fonte de carbono para o crescimento microbiano) e o par ácido/base $\mathrm{HS}^{-} / \mathrm{H}_{2} \mathrm{~S}$ para transferência para a fase gasosa como gás sulfídrico $\left(\mathrm{H}_{2} \mathrm{~S}\right)$.

O processo de desnitrificação não foi incluído no ADM1, apesar de ter impacto significante no fluxo de carbono e de elétrons, na competição entre microrganismos, no processo de inibição e na composição do biogás. Para considerar esse processo, dentre outras variáveis, seria necessário adicionar um grupo extra de microrganismos (desnitrificantes) com parâmetros cinéticos específicos para consumo de substrato, funções para divisão do substrato entre as populações fermentativas/metanogênicas e desnitrificantes, modelos de inibição.

O processo de homoacetogênese não foi contemplado no modelo, pois incluílo acarretaria descrever a competição entre as metanogênicas hidrogenotróficas e os microrganismos homoacetogênicos por moléculas de hidrogênio e de dióxido de carbono (BATSTONE, et al., $2000^{11}$ apud VAVILIN, 2000).

11 Batstone, D.J.; Keller, J.; Newell, R.B.; Newland, M. (2000). Modelling anaerobic degradation of complex wastewater. I: Model development. Bioresource Technology, n.75, p.67-74. 


\subsection{PROCESSOS FÍSICO-QUÍMICOS}

Em sistemas com níveis médios e elevados de íons, e especialmente em sistemas ascendentes com recirculação de efluente, deve ser estimado um coeficiente que represente a atividade iônica.

É muito importante contemplar os processos físico-químicos na modelação de sistemas anaeróbios, pois podem ser apresentados alguns fatores que inibem os processos biológicos tais como $\mathrm{pH}$, ácidos e bases livres, concentrações de gases na fase líquida; variáveis que dependem de corretas estimativas de processos físicoquímicos, tais como fluxo gasoso e alcalinidade a bicarbonato; custos com o controle de $\mathrm{pH}$ com uso de ácidos e bases fortes, geralmente calculados por estimativas de processos físico-químicos.

Como os processos de associação/dissociação iônica são muito rápidos, eles são geralmente considerados como reações em equilíbrio, podendo ser representados por um conjunto de equações algébricas.

O conjunto de equações diferenciais ordinárias do modelo ADM1 está relacionado abaixo:

$$
\begin{array}{lr}
\rho_{1}=k_{d i s s} \cdot X_{c} & \text { Equação 16 } \\
\rho_{2}=k_{h y d, c h} \cdot X_{c h} & \text { Equação 17 } \\
\rho_{3}=k_{h y d, p r} \cdot X_{p r} & \text { Equação 18 } \\
\rho_{4}=k_{h y d, l i} \cdot X_{l i} & \text { Equação 19 } \\
\rho_{5}=k_{m, s u} \cdot \frac{S_{s u}}{K_{S, s u}+S_{s u}} \cdot X_{s u} \cdot I_{5} &
\end{array}
$$




$$
\rho_{6}=k_{m, a a} \cdot \frac{S_{a a}}{K_{S, a a}+S_{a a}} \cdot X_{a a} \cdot I_{6}
$$

Equação 21

$$
\rho_{7}=k_{m, f a} \cdot \frac{S_{f a}}{K_{S, f a}+S_{f a}} \cdot X_{f a} \cdot I_{7}
$$

Equação 22

$$
\rho_{8}=k_{m, c 4} \cdot \frac{S_{v a}}{K_{S, c 4}+S_{v a}} \cdot X_{c 4} \cdot \frac{S_{v a}}{S_{b u}+S_{v a}+1 e^{-6}} I_{8}
$$

Equação 23

$$
\rho_{9}=k_{m, c 4} \cdot \frac{S_{b u}}{K_{S, c 4}+S_{b u}} \cdot X_{c 4} \cdot \frac{S_{b u}}{S_{b u}+S_{v a}+1 e^{-6}} I_{9}
$$

Equação 24

$$
\rho_{10}=k_{m, p r} \cdot \frac{S_{p r o}}{K_{S, p r o}+S_{p r o}} \cdot X_{p r o} . I_{10}
$$

Equação 25

$$
\rho_{11}=k_{m, a c} \cdot \frac{S_{a c}}{K_{S, a c}+S_{a c}} \cdot X_{a c} \cdot I_{11}
$$

Equação 26

$$
\rho_{12}=k_{m, h 2} \cdot \frac{S_{h 2}}{K_{S, h 2}+S_{h 2}} \cdot X_{h 2} \cdot I_{12}
$$

Equação 27

$$
\rho_{13}=k_{d e c, x s u} \cdot X_{s u}
$$

Equação 28

$$
\rho_{14}=k_{d e c, x a a} \cdot X_{a a}
$$

Equação 29

$\rho_{15}=k_{d e c, x f a} \cdot X_{f a}$

Equação 30

$$
\rho_{16}=k_{d e c, x c 4} \cdot X_{c 4}
$$




$$
\rho_{17}=k_{\text {dec,xpro }} \cdot X_{\text {pro }}
$$

$$
\rho_{18}=k_{d e c, a c} \cdot X_{a c}
$$

$$
\rho_{19}=k_{d e c, h 2} \cdot X_{h 2}
$$

\section{Equação 32}

Equação 33

Equação 34

As equações de taxas para os pares ácidos/bases são apresentadas pelas Equações 35 a 40.

$$
\begin{array}{ll}
\rho_{A, 4}=k_{A, B v a}\left(S_{v a}-\left(K_{a, v a}+S_{H^{+}}\right)-k_{a, v a} S_{v a}\right. & \text { Equação 35 } \\
\rho_{A, 5}=k_{A, B b u}\left(S_{b u}-\left(K_{a, b u}+S_{H^{+}}\right)-k_{a, b u} S_{b u}\right. & \text { Equação 36 } \\
\rho_{A, 6}=k_{A, B p r o}\left(S_{p r o}-\left(K_{a, p r o}+S_{H^{+}}\right)-k_{a, p r o} S_{p r o}\right. & \text { Equação 37 } \\
\rho_{A, 7}=k_{A, B a c}\left(S_{a c}-\left(K_{a, a c}+S_{H^{+}}\right)-k_{a, a c} S_{a c}\right. & \text { Equação 38 } \\
\rho_{A, 10}=k_{A, B c o 2}\left(S_{h c o 3}-\left(K_{a, c o 2}+S_{H^{+}}\right)-k_{a, c o 2} S_{I C}\right. & \\
\rho_{A, 11}=k_{A, B I N}\left(S_{n h 3}-\left(K_{a, I N}+S_{H^{+}}\right)-k_{a, I N} S_{I N}\right. & \text { Equação 39 }
\end{array}
$$

\section{Equação 35}

\section{Equação 40}

As equações de taxas de transferência de gases $\left(\mathrm{S}_{\mathrm{CO} 2}\right.$ é aplicado na equação para T,10 e não para SIC) são apresentadas pelas Equações 41 a 43.

$$
\begin{aligned}
& \rho_{T, 8}=k_{L} a\left(S_{h 2}-16 K_{H, h 2} \rho_{g a s, h 2}\right) \\
& \rho_{T, 9}=k_{L} a\left(S_{c h 4}-64 K_{H, c h 4} \rho_{g a s, c h 4}\right) \\
& \rho_{T, 10}=k_{L} a\left(S_{c o 2}-K_{H, c o 2} \rho_{g a s, c o 2}\right)
\end{aligned}
$$

Equação 42

Equação 43 
Os processos de inibição são apresentados pelas Equações 442 a 57.

$$
I_{5,6}=I_{p H, a a} . I_{I N, \lim }
$$

Equação 44

$$
I_{7}=I_{p H, a a} \cdot I_{I N, \lim } \cdot I_{h 2, f a}
$$

Equação 45

$$
\begin{aligned}
& I_{8,9}=I_{p H, a a} \cdot I_{I N, \lim } \cdot I_{h 2, c 4} \\
& I_{10}=I_{p H, a a} \cdot I_{I N, \lim } \cdot I_{h 2, p r o}
\end{aligned}
$$

Equação 46

Equação 47

$$
I_{11}=I_{p H, a c} \cdot I_{I N, \lim } \cdot I_{n h 3}
$$

Equação 48

$$
I_{12}=I_{p H, h 2} \cdot I_{I N, \mathrm{lim}}
$$

Equação 49

$$
I_{p H, a a}=\left\{{ }_{1} \exp \left(-3\left(\frac{p H-p H_{U L, a a}}{p H_{U L, a a}-p H_{L L, a a}}\right)^{2}\right)\right.
$$

$$
I_{p H, a c}=\left\{{ }_{1} \exp \left(-3\left(\frac{p H-p H_{U L, a c}}{p H_{U L, a c}-p H_{L L, a c}}\right)^{2}\right)\right.
$$

$$
I_{p H, h 2}=\left\{{ }_{1} \exp \left(-3\left(\frac{p H-p H_{U L, h 2}}{p H_{U L, h 2}-p H_{L L, h 2}}\right)^{2}\right)\right.
$$

Equação 52

$$
\begin{gathered}
I_{I N, \lim }=\frac{1}{1+K_{S, I N} / S_{I N}} \\
I_{H 2, f a}=\frac{1}{1+S_{h 2} / K_{I, h 2, f a}}
\end{gathered}
$$

Equação 50

Equação 51

\section{Equação 53}

Equação 54 


$$
\begin{aligned}
& I_{h 2, c 4}=\frac{1}{1+S_{h 2} / K_{I, h 2, c 4}} \\
& I_{h 2, p r o}=\frac{1}{1+S_{h 2} / K_{I, h 2, p r o}} \\
& I_{n h 3}=\frac{1}{1+S_{n h 3} / K_{I, n h 3}}
\end{aligned}
$$

\section{Equação 55}

Equação 56

Equação 57

As equações da fase líquida para material solúvel são apresentadas pelas Equações 58 a 84 .

$$
\begin{aligned}
& \frac{d S_{s u}}{d t}=\frac{q_{i n}}{V_{l i q}}\left(S_{s u, i n}-S_{s u}\right)+\rho_{2}+\left(1-f_{f a, l i}\right) \rho_{4}-\rho_{5} \\
& \frac{d S_{a a}}{d t}=\frac{q_{i n}}{V_{l i q}}\left(S_{a a, i n}-S_{a a}\right)+\rho_{3}-\rho_{6}
\end{aligned}
$$

Equação 58

$$
\frac{d S_{f a}}{d t}=\frac{q_{i n}}{V_{l i q}}\left(S_{f a, i n}-S_{f a}\right)+f_{f a, l i} \rho_{4}-\rho_{7}
$$

Equação 59

$$
\frac{d S_{v a}}{d t}=\frac{q_{i n}}{V_{l i q}}\left(S_{v a, i n}-S_{v a}\right)+\left(1-Y_{a a}\right) f_{v a, a a} \rho_{6}-\rho_{8}
$$

Equação 60

$$
\frac{d S_{b u}}{d t}=\frac{q_{i n}}{V_{l i q}}\left(S_{b u, i n}-S_{b u}\right)+\left(1-Y_{s u}\right) f_{b u, s u} \rho_{5}+\left(1-Y_{a a}\right) f_{b u, a a} \rho_{6}-\rho_{9}
$$

\section{Equação 61}

Equação 62 


$$
\begin{aligned}
& \frac{d S_{p r o}}{d t}=\frac{q_{\text {in }}}{V_{\text {liq }}}\left(S_{\text {pro, }, \mathrm{in}}-S_{\text {pro }}\right)+\left(1-Y_{s u}\right) f_{\text {pro, }, \mathrm{su}} \rho_{5}+\left(1-Y_{a a}\right) f_{p r o, a a} \rho_{6}+ \\
& \left(1-Y_{c 4}\right) 0.54 \rho_{8}-\rho_{10} \\
& \frac{d S_{a c}}{d t}=\frac{q_{i n}}{V_{l i q}}\left(S_{a c, i n}-S_{a c}\right)+\left(1-Y_{s u}\right) f_{a c, s u} \rho_{5}+\left(1-Y_{a a}\right) f_{a c, a a} \rho_{6}+\left(1-Y_{f a}\right) 0.7 \rho_{7}+ \\
& \left(1-Y_{c 4}\right) 0.31 \rho_{8}+\left(1-Y_{c 4}\right) 0.8 \rho_{9}+\left(1-Y_{p r o}\right) 0.57 \rho_{10}-\rho_{11}
\end{aligned}
$$

\section{Equação 64}

$$
\begin{aligned}
& \frac{d S_{h 2}}{d t}=\frac{q_{i n}}{V_{l i q}}\left(S_{h 2, i n}-S_{h 2}\right)+\left(1-Y_{s u}\right) f_{a c, s u} \rho_{5}+\left(1-Y_{a a}\right) f_{a c, a a} \rho_{6}+\left(1-Y_{f a}\right) 0.3 \rho_{7}+ \\
& \left(1-Y_{c 4}\right) 0.15 \rho_{8}+\left(1-Y_{c 4}\right) 0.2 \rho_{9}+\left(1-Y_{p r o}\right) 0.43 \rho_{10}-\rho_{12}-\rho_{T, 8}
\end{aligned}
$$

Equação 65

$$
\frac{d S_{c h 4}}{d t}=\frac{q_{i n}}{V_{l i q}}\left(S_{c h 4, i n}-S_{c h 4}\right)+\left(1-Y_{a a}\right) \rho_{11}+\left(1-Y_{h 2}\right) \rho_{12}-\rho_{T, 9}
$$

Equação 66

$$
\begin{aligned}
& \frac{d S_{I C}}{d t}=\frac{q_{\text {in }}}{V_{l i q}}\left(S_{I C, \text { in }}-S_{I C}\right)-\sum_{j=1}^{19}\left(\sum_{1=1-9,11-24} C_{i} v_{i, j} \rho_{j}\right)-\rho_{T, 10} \quad \text { Equação 67 } \\
& \frac{d S_{I N}}{d t}=\frac{q_{i n}}{V_{l i q}}\left(S_{I N, \text { in }}-S_{I N}\right)-Y_{s u} N_{b a c} \rho_{5}+\left(N_{a a}-Y_{a a} N_{b a c}\right) \rho_{6}-Y_{f a} N_{b a c} \rho_{7}-
\end{aligned}
$$

Equação 68

$$
Y_{c 4} N_{b a c} \rho_{8}-Y_{c 4} N_{b a c} \rho_{9}-Y_{p r o} N_{b a c} \rho_{10}-Y_{a c} N_{b a c} \rho_{11}-Y_{h 2} N_{b a c} \rho_{12}+\left(N_{b a c}-N_{x c}\right)
$$

Equação 69

$$
\sum_{i=13}^{19} \rho_{i}+\left(N_{x c}-f_{x I, x c} N_{I}-f_{p r, x c} N_{a a}\right) \rho_{1}
$$

\section{Equação 70}




$$
\begin{aligned}
& \frac{d S_{I}}{d t}=\frac{q_{\text {in }}}{V_{l i q}}\left(S_{I, i n}-S_{I}\right)+f_{s I, x c} \rho_{1} \\
& \sum_{j=1}^{19}\left(\sum_{1=1-9,11-24} C_{i} v_{i, j} \rho_{j}\right)=\sum_{k=1}^{12} s_{k} \rho_{k}+s_{13}\left(\rho_{14}+\rho_{15}+\rho_{16}+\rho_{17}+\rho_{18}+\rho_{13}+\rho_{19}\right)
\end{aligned}
$$

Equação 71,

em que:

$$
\begin{array}{lr}
s_{1}=-C_{x c}+f_{s I, x c} C_{s I}+f_{c h, x c} C_{c h}+f_{p r, x c} C_{p r}+f_{l i, x c} C_{l i} & \text { Equação 72 } \\
s_{2}=-C_{c h}+C_{s u} & \text { Equação 73 } \\
s_{3}=-C_{p r}+C_{a a} & \text { Equação 74 } \\
s_{4}=-C_{l i}+\left(1-f_{f a, l i}\right) C_{s u}+f_{f a, l i} C_{f a} & \text { Equação 75 } \\
s_{5}=-C_{s u}+\left(1-Y_{s u}\right)\left(f_{b u, s u} C_{b u}+f_{p r o, s u} C_{p r o}+f_{a c, s u} C_{a c}\right)+Y_{s u} C_{b a c} & \text { Equação 76 } \\
s_{6}=-C_{a a}+\left(1-Y_{a a}\right)\left(f_{v a, a a} C_{v a}+f_{b u, a a} C_{b u}+f_{p r o, a a} C_{p r o}+f_{a c, a a} C_{a c}\right)+Y_{a a} C_{b a c}
\end{array}
$$

Equação 77

$$
\begin{aligned}
& s_{7}=-C_{f a}+\left(1-Y_{f a}\right) 0.7 C_{a c}+Y_{f a} C_{b a c} \\
& s_{8}=-C_{v a}+\left(1-Y_{c 4}\right) 0.54 C_{p r o}+\left(1-Y_{c 4}\right) 0.31 C_{a c}+Y_{c 4} C_{b a c} \\
& s_{9}=-C_{b u}+\left(1-Y_{c 4}\right) 0.8 C_{a c}+Y_{c 4} C_{b a c} \\
& s_{10}=-C_{p r o}+\left(1-Y_{p r o}\right) 0.57 C_{a c}+Y_{p r o} C_{b a c}
\end{aligned}
$$

Equação 79

Equação 80

Equação 81 


$$
\begin{aligned}
& s_{11}=-C_{a c}+\left(1-Y_{a c}\right) C_{c h 4}+Y_{a c} C_{b a c} \\
& s_{12}=\left(1-Y_{h 2}\right) C_{c h 4}+Y_{h 2} C_{b a c} \\
& s_{13}=-C_{b a c}+C_{x c}
\end{aligned}
$$

\section{Equação 82}

Equação 83

Equação 84

As equações diferenciais correspondentes ao material particulado são apresentadas pelas Equações 85 a 96.

$$
\begin{aligned}
& \frac{d X_{c}}{d t}=\frac{q_{i n}}{V_{l i q}}\left(X_{c, i n}-X_{c}\right)-\rho_{1}+\sum_{1=13}^{19} \rho_{i} \\
& \frac{d X_{c h}}{d t}=\frac{q_{i n}}{V_{l i q}}\left(X_{c h, i n}-X_{c h}\right)+f_{c h, x c} \rho_{1}-\rho_{2}
\end{aligned}
$$

Equação 85

$$
\frac{d X_{p r}}{d t}=\frac{q_{i n}}{V_{l i q}}\left(X_{p r, i n}-X_{p r}\right)+f_{p r, x c} \rho_{1}-\rho_{3}
$$

Equação 86

$$
\frac{d X_{l i}}{d t}=\frac{q_{i n}}{V_{l i q}}\left(X_{l i, i n}-X_{l i}\right)+f_{l i, x c} \rho_{1}-\rho_{4}
$$

Equação 87

$$
\frac{d X_{s u}}{d t}=\frac{q_{i n}}{V_{l i q}}\left(X_{s u, i n}-X_{s u}\right)+Y_{s u} \rho_{5}-\rho_{13}
$$

Equação 88

$$
\frac{d X_{a a}}{d t}=\frac{q_{i n}}{V_{l i q}}\left(X_{a a, i n}-X_{a a}\right)+Y_{a a} \rho_{6}-\rho_{14}
$$

Equação 89

$$
\frac{d X_{f a}}{d t}=\frac{q_{i n}}{V_{l i q}}\left(X_{f a, i n}-X_{f a}\right)+Y_{f a} \rho_{7}-\rho_{15}
$$

Equação 90

Equação 91 


$$
\frac{d X_{c 4}}{d t}=\frac{q_{i n}}{V_{l i q}}\left(X_{c 4, i n}-X_{c 4}\right)+Y_{c 4} \rho_{8}+Y_{c 4 \rho_{9}}-\rho_{16}
$$

Equação 92

$$
\frac{d X_{p r o}}{d t}=\frac{q_{\text {in }}}{V_{\text {liq }}}\left(X_{p r o, i n}-X_{p r o}\right)+Y_{p r o} \rho_{10}-\rho_{17}
$$

Equação 93

$$
\frac{d X_{a c}}{d t}=\frac{q_{i n}}{V_{l i q}}\left(X_{a c, i n}-X_{a c}\right)+Y_{a c} \rho_{11}-\rho_{18}
$$

Equação 94

$$
\frac{d X_{h 2}}{d t}=\frac{q_{i n}}{V_{l i q}}\left(X_{h 2, i n}-X_{h 2}\right)+Y_{h 2} \rho_{12}-\rho_{19}
$$

\section{Equação 95}

$$
\frac{d X_{I}}{d t}=\frac{q_{i n}}{V_{l i q}}\left(X_{I, i n}-X_{I}\right)+f_{x I, x c} \rho_{1}
$$

\section{Equação 96}

As equações diferenciais correspondentes aos cátions e ânions são apresentadas pelas Equações 97 a 98 .

$$
\begin{aligned}
& \frac{d S_{c a t^{+}}}{d t}=\frac{q_{\text {in }}}{V_{l i q}}\left(S_{c a t^{+}}-S_{c a t^{+}}\right) \\
& \frac{d S_{a n^{-}}}{d t}=\frac{q_{i n}}{V_{l i q}}\left(S_{a n^{-}}-S_{a n^{-}}\right)
\end{aligned}
$$

Equação 97

\section{Equação 98}

As equações diferenciais para as variáveis de estado iônico são apresentadas pelas Equações 99 a 104.

$$
\frac{d S_{v a^{-}}}{d t}=-\rho_{A, 4}
$$

\section{Equação 99}




$$
\begin{aligned}
& \frac{d S_{b u^{-}}}{d t}=-\rho_{A, 5} \\
& \frac{d S_{p r 0^{-}}}{d t}=-\rho_{A, 6} \\
& \frac{d S_{a c^{-}}}{d t}=-\rho_{A, 7} \\
& \frac{d S_{h c o 3^{-}}}{d t}=-\rho_{A, 10} \\
& \frac{d S_{n h 3}}{d t}=-\rho_{A, 11}
\end{aligned}
$$

Equação 101

Equação 102

\section{Equação 103}

\section{Equação 104}

As equações algébricas são apresentadas pelas Equações 1053 a 108.

$$
\begin{aligned}
& S_{H^{+}=\frac{-\Theta}{2}+\frac{1}{2} \sqrt{\Theta^{2}+4 K_{W}}} \\
& \Theta=S_{c a t^{+}} S_{n h 4}^{+}-S_{h c 3^{-}}-\frac{S_{a c^{-}}}{64}-\frac{S_{p r^{-}}}{112}-\frac{S_{b u}^{-}}{160}-\frac{S_{v a^{-}}}{208}-S_{a n^{-}} \\
& S_{n h 4^{+}}=S_{I N}-S_{n h 3} \\
& S_{c o 2}=S_{I C}-S_{h c o 3^{-}}
\end{aligned}
$$

Equação 105

Equação 106

\section{Equação 107}

Equação 108

As equações diferenciais para as variáveis de estado gasoso são apresentadas pelas Equações 109 a 111. 


$$
\begin{aligned}
& \frac{d S_{g a ́ s, h 2}}{d t}=-\frac{S_{g a ́ s, h 2} q_{g a ́ s}}{V_{g a ́ s}}+\rho_{T, 8} \cdot \frac{V_{\text {liq }}}{V_{g a ́ s}} \\
& \frac{d S_{g a ́ s, c h 4}}{d t}=-\frac{S_{g a ́ s, c h 4} q_{g a ́ s}}{V_{g a ́ s}}+\rho_{T, 9} \cdot \frac{V_{\text {liq }}}{V_{g a ́ s}} \\
& \frac{d S_{g a ́ s, c o 2}}{d t}=-\frac{S_{g a ́ s, c o 2} q_{g a ́ s}}{V_{g a ́ s}}+\rho_{T, 10} \cdot \frac{V_{l i q}}{V_{g a ́ s}}
\end{aligned}
$$

Equação 109

Equação 110

Equação 111

As equações algébricas são apresentadas pelas Equações 112 a 115 .

$$
p_{\text {gás }, h 2}=S_{g a ́ s, h 2} \cdot \frac{R T_{o p}}{16}
$$

Equação 112

$$
p_{g a ́ s, c h 4}=S_{g a ́ s, c h 4} \cdot \frac{R T_{o p}}{64}
$$

$$
p_{g a ́ s, c o 2}=S_{g a ́ s, c o 2} \cdot R T_{o p}
$$

Equação 114

$$
q_{g a ́ s}=\frac{R T_{o p}}{P_{a t m}-p_{g a ́ s, H 2 O}} \cdot V_{l i q}\left(\frac{\rho_{T, 8}}{16}+\frac{\rho_{T, 9}}{64}+\rho_{T, 10}\right)
$$

\section{Equação 115}

\subsection{ROTINA COMPUTACIONAL DO MODELO MMS}

A Tabela 42 apresenta a rotina com as equações de balanço de massa do arquivo reator. $m$ desenvolvida no Matlab para o modelo MMS. 


\section{Tabela 42. Rotina do arquivo reator.m do modelo MMS}

function ds=reator $(\mathrm{t}, \mathrm{x})$;

global q SSa k Yb Cs v Q a w;

$\mathrm{q}=[\mathrm{Q} *(1+\mathrm{a} * \sin (\mathrm{w} * \mathrm{t}))]$

\%Função da DQO afluente variando ao longo do tempo, considerando intervalo de 0 a $21 \mathrm{~h}$

$\mathrm{SSa}=0.0005 * \mathrm{t}^{\wedge} 6-0.0317 * \mathrm{t}^{\wedge} 5+0.8452 * \mathrm{t}^{\wedge} 4-11.107 * \mathrm{t}^{\wedge} 3+75.037 * \mathrm{t}^{\wedge} 2-251.38 * \mathrm{t}+$ 968.76

\%MODELO CINETICO DE PRIMEIRA ORDEM PARA CONSUMO DE SUBSTRATO

\%MODELO CINETICO DE PRIMEIRA ORDEM PARA CRESCIMENTO MICROBIANO

$\% \times(1)=\mathrm{DQO}(\mathrm{mg} / \mathrm{L})$ do efluente do compartimento I;

$\% \mathrm{x}(2)=\mathrm{SSV}(\mathrm{mg} / \mathrm{L})$ do efluente do compartimento I;

$\% \times(3)=\mathrm{DQO}(\mathrm{mg} / \mathrm{L})$ do efluente do compartimento II;

$\% \mathrm{x}(4)=\mathrm{SSV}(\mathrm{mg} / \mathrm{L})$ do efluente do compartimento II;

$\% \times(5)=\mathrm{DQO}(\mathrm{mg} / \mathrm{L})$ do efluente do compartimento III;

$\% \mathrm{x}(6)=\mathrm{SSV}(\mathrm{mg} / \mathrm{L})$ do efluente do compartimento III;

$\% \times(7)=\mathrm{DQO}(\mathrm{mg} / \mathrm{L})$ do efluente do compartimento IV;

$\% x(8)=\mathrm{SSV}(\mathrm{mg} / \mathrm{L})$ do efluente do compartimento IV;

\%Compartimento I

\%substrato:

$\mathrm{ds}(1)=\mathrm{q} / \mathrm{v}(1) *(\operatorname{SSa}(1)-\mathrm{x}(1))-(\mathrm{k}(1) * \mathrm{x}(1))$;

\%biomassa:

$\mathrm{ds}(2)=-\mathrm{q} / \mathrm{v}(1) * \mathrm{x}(2)+(\mathrm{Yb} * \mathrm{k}(1) * \mathrm{x}(1))$;

\%Compartimento II

\%substrato:

$\mathrm{ds}(3)=\mathrm{q} / \mathrm{v}(2) *(\mathrm{x}(1)-\mathrm{x}(3))-(\mathrm{k}(2) * \mathrm{x}(3))$;

\%biomassa:

$\mathrm{ds}(4)=\left(\mathrm{Cs}^{*} \mathrm{q} * \mathrm{x}(6) / \mathrm{v}(4)\right)+(\mathrm{q} / \mathrm{v}(2) *(\mathrm{x}(2)-\mathrm{x}(4)))+(\mathrm{Yb} * \mathrm{k}(2) * \mathrm{x}(3))$;

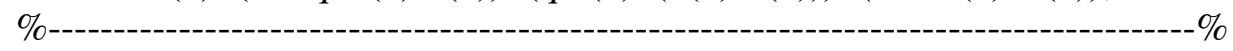

\%Compartimento III:

\%substrato:

$\mathrm{ds}(5)=\mathrm{q} / \mathrm{v}(3) *(\mathrm{x}(3)-\mathrm{x}(5))-\mathrm{k}(3) * \mathrm{x}(5)$;

\%biomassa:

$\mathrm{ds}(6)=\mathrm{q} / \mathrm{v}(3) *(\mathrm{x}(4)-\mathrm{x}(6))+(\mathrm{Yb} * \mathrm{k}(3) * \mathrm{x}(5))$;

$\%$

\%Compartimento IV: não ha reação nesse compartimento, apenas separação das fases, $\log \mathrm{k}(4)=0$;

\%substrato: 


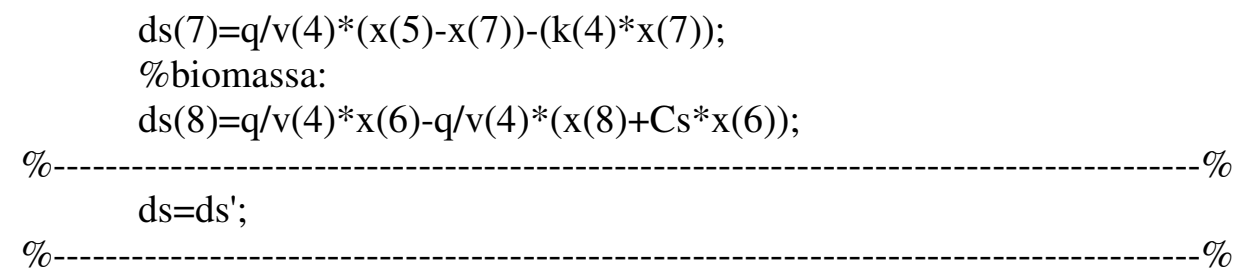

A Tabela 43 apresenta a rotina com os dados de entrada do arquivo reator16.m desenvolvida no Matlab para o modelo MMS.

\section{Tabela 43. Rotina do arquivo reator 16. $m$ do modelo MMS}

\% Programa para avaliação da resposta do reator UASB não submetido a variação da vazão afluente

$\%$ Reator dividido em quatro compartimentos isotérmicos

$\%$ Dados gerais - perfil temporal do reator UASB

\% Parâmetros cinéticos - otimizados pela função $\mathrm{F}$

clear

clc

global q SSa k Yb Cs v Q a w;

\section{$\mathrm{SSa}$}

$\mathrm{v}(1)=[44] ; \%$ volume do reator $1(\mathrm{~L})$;

$\mathrm{v}(2)=[44] ; \%$ volume do reator $2(\mathrm{~L})$;

$\mathrm{v}(3)=[44] ; \%$ volume do reator $3(\mathrm{~L})$;

$\mathrm{v}(4)=[42] ; \%$ volume do reator $4(\mathrm{~L})$;

Xbre $=[\mathrm{Cs} * 4300] ; \%$ concentração de biomassa no escoamento de retorno interno do compartimento 4 para o $1\left(\mathrm{mgSSV} . \mathrm{L}^{-1}\right)$;

$\mathrm{Cs}=[0.8] ; \%$ constante de separação do separador de fases (adimensional);

$\mathrm{Q}=[18.25] ; \%$ vazão média afluente $\left(\mathrm{L} . \mathrm{h}^{-1}\right)$;

$\mathrm{a}=[0.0] ; \%$ amplitude decimal relativa $(0<\mathrm{alfa}<1)$;

$\mathrm{w}=[1] ; \%$ freqüência da variação da vazão $(0<\mathrm{w}<3.1415 / 2)$;

$\mathrm{ta}=[0: 3: 21] ; \%$ intervalo de tempo $(1 \mathrm{dia}=24 \mathrm{~h})$;

$\mathrm{q}=\left[\mathrm{Q} *\left(1+\mathrm{a}^{*} \sin (\mathrm{w} * \mathrm{ta})\right)\right] ; \%$ vazão senoidal $\left(\mathrm{L} \cdot \mathrm{h}^{-1}\right)$;

$\mathrm{Yb}=[0.15] ; \%$ coeficiente de conversão de substrato em microrganismos (mgSSV.mgDQO ${ }^{-1}$ );

Dxbr $=[\mathrm{Cs} * \mathrm{q} * 300 / \mathrm{v}(4)] ; \%$ descarga de biomassa retornada ao compartimento 2;

\%vetor de inicialização para período de $0 \mathrm{~h}$ a $21 \mathrm{~h}$.

[T X]=ode45(@reator,ta,[240 19000300140001008500182 4300]);

plot $(\mathrm{T}, \mathrm{X})$;

title('Variação de DQOef x tempo (mg.L $\left.\left.\mathrm{L}^{-1}\right)^{\prime}\right)$;

Xlabel('tempo (h)');

Ylabel('DQOef $\left.\left(\mathrm{mg} . \mathrm{L}^{-1}\right)^{\prime}\right)$;

hold on 